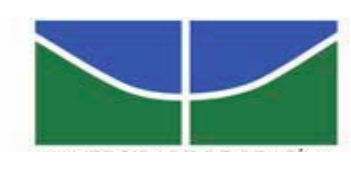

UNIVERSIDADE DE BRASÍLIA

Centro de Excelência em Turismo

Pós-graduação Lato Sensu

Curso de Especialização em Gestão de Negócios em Turismo

\title{
MEMÓRIA DO TURISMO: \\ TRAJETÓRIA HISTÓRICA DA EMBRATUR NO \\ PERÍODO DE 1966 A 2006
}

WALDINEIA FERREIRA WALDMANN BRASIL

Dra. Maria Elenita Menezes Nascimento

Orientadora

Brasília - 2007 


\section{UNIVERSIDADE DE BRASÍLIA}

Centro de Excelência em Turismo

Pós-graduação Lato Sensu

Curso de Especialização em Gestão de Negócios em Turismo

\section{MEMÓRIA DO TURISMO: \\ TRAJETÓRIA HISTÓRICA DA EMBRATUR NO \\ PERÍODO DE 1966 A 2006}

WALDINEIA FERREIRA WALDMANN BRASIL

Dra. Maria Elenita Menezes Nascimento

Orientadora

Monografia apresentada ao Centro de Excelência em Turismo - CET, da Universidade de Brasília - UNB, como requisito parcial à obtenção do grau de Especialista em Gestão de Negócios em Turismo.

Brasília, 2007 
Brasil, Waldineia Ferreira Waldmann Memória do Turismo: Trajetória Histórica da EMBRATUR no período de 1966 a 2006 Waldineia Ferreira Waldmann Brasil - Brasília 2006 $\mathrm{XI}$, 91fl, il

Monografia (Gestão de Negócios em Turismo) - Universidade de Brasília, Centro de Excelência em Turismo, 2007.

Orientadora: Profa. Dra. Maria Elenita M. Nascimento

1. EMBRATUR 2. Historia do Turismo no Brasil 3. Políticas Públicas 4. Gestão do Turismo 


\section{UNIVERSIDADE DE BRASÍLIA}

Centro de Excelência em Turismo Pós-graduação Lato Sensu

Curso de Especialização em Gestão de Negócios em Turismo

WALDINEIA FERREIRA WALDMANN BRASIL

Aprovado por:

Dra. Maria Elenita Menezes Nascimento

Orientadora

\section{Dra. Iara Lúcia Gomes Brasileiro \\ Examinadora}

\section{MSc. Helena Araújo Costa \\ Examinadora}

Brasília, 30 de março de 2007. 
Dedico à minha mãe (in memorian), meus amados filhos, Bárbara e Filllip e ao meu irmão, por sempre terem me dado força, apoio e, principalmente, amor nos momentos em que mais precisei. 


\section{AGRADECIMENTOS}

Em primeiro lugar agradeço a Deus por ter me dado discernimento suficiente para fazer minhas escolhas e por ser o meu guia.

A minha orientadora professora. Dra. Maria Elenita M. Nascimento pelas idéias e orientação, que muito ajudaram a elaboração deste trabalho e que esteve presente sempre que precisava, até mesmo quando estava com muito afazeres.

Agradeço a minha mãe (in memoriam) que em toda sua vida, meu deu força para que eu realizasse cada sonho que tinha, aos meus filhos, que aceitaram que eu me dedicasse com todo afinco à conclusão deste trabalho. Ao meu irmão, pelo apoio e às tantas família que deixei no Rio, Waldmann (D. Yara, Olga e Augusto, Sonia e Moacyr), a Monteiro (Kátia, D. Tereza e Eva), Almirante (D. Neuza, D. Neli e D. Nice), a Oliveira (Homero, Rosangela e D. Margarida) e a Cunha (Celso e sua baixinha).

A minha amiga Leila e sua família, que apesar de estarem tão longe, sempre me apoiaram em tudo que eu fiz desde que nos conhecemos. Aos meus amigos do Rio de Janeiro, que deixaram saudades, Cristina e Kristy, Zizi e Tamy , Layze Lima, D. Maria, Marta Rocha e sua família. Além dos que me apoiaram na pesquisa e elaboração deste trabalho, Carlos Roberto Ribas, Dr. Gerson Fonseca, Dr. Reinaldo Nunes, Miriam Cardia (Mixirica) e Patrícia Fernandes, demonstrando presteza e dedicação ao me fornecerem todas as informações necessárias à elaboração deste trabalho. Aos meus de Brasília, pela força que me deram, Lindalva e família, Luiz Ferreira, D. Salete e seu querido Nego, Sara Agra, Julia Maria e principalmente meus orientadores não oficiais, Beatrice Laura Carnielli, Atair Carneiro Costa e Sheila Silveira.

A todos aqueles que pacientemente me concederam entrevistas, apesar de atarefados que são, os ex-presidentes da EMBRATUR, Sr. Miguel Colasuonno, Sr. João Dória Junior, os presidentes das entidades de turismo, Sr. Heraldo Alves (presidente da ABIH/Nacional, Sra. Simone Saccoman (presidente ABEOC), Sra. Margareth Caron (presidente ABRACEFF), Sr. Michel Tuma Ness (presidente da FENACTUR) e os jornalistas de turismo, Srs. Cláudio Magnavita (Jornal de Turismo), Antônio Euryco (Brasilturis), Mario Brizon (Folha de Turismo).

A todos os servidores da EMBRATUR (aposentados, ativos e ex-funcionários) que também concederam entrevista para elaboração deste trabalho, Eliana Jorge Melo, Dr. Joandre Ferraz (ex-diretor da EMBRATUR), Marcos Niemeyer, Miriam Cárdia, Roberto Góes e Patrícia Fernandes.

À Diretoria da EMBRATUR, que muito colaborou com a pesquisa inicial deste trabalho, ao permitir o acesso aos arquivos da empresa. A todos com quem tenho o prazer de trabalhar, principalmente aos servidores da Gerência de Eventos Promocionais, Wilson Freitas (Wilson "prestativo"), Clara Maria Odete, Luciana Reis ("Luluzinha", a amorosa), Júlio Medeiros 
(o "bom senso"), Cinthia Silva (Cinther), Bruna Franco (a "Anjinho"), Juliana Germanos (o "Olhar Brilhante") pelo apoio, paciência e companheirismo que tiveram no período da elaboração e finalização deste trabalho.

Às amizades que fiz durante o curso de pós-graduação, que ficarão para sempre no meu coração. Ao pessoal da minha turma que me agüentou não só durante as aulas, mas também em casa: Kellen, Rodrigo, Sheila e Tadeu. A minha amiga Gabrielle, pelas simpáticas caronas. Aos membros da Secretaria, que tanto me ajudou nas necessidades que tive, durante o curso, "nossos queridos" Luiz Melo e Pedro. Também, ao nosso tão prestativo coordenador do curso Professor Domingos Spézia e sua equipe de professores. 
"Gostaria de apenas deixar registrado que o trabalho que realizamos a frente da EMBRATUR, durante dois anos e sete meses, foi apesar de curto período, vitorioso, sobretudo pelo espírito de equipe, por valorizar o talento dos profissionais que já estavam na EMBRATUR, o chamado corpo técnico estável, ao que se somaram profissionais que comigo participaram desta emocionante experiência de dirigir o Turismo brasileiro e as suas políticas de atuação de maneira muito vibrante."

(João Dória Junior - ex-presidente da EMBRATUR) 


\section{RESUMO}

O presente estudo apresenta a trajetória histórica da EMBRATUR - Instituto Brasileiro de Turismo no período de 1966 a 2006, ressaltando sua contribuição para o desenvolvimento da indústria do turismo brasileiro, justificada pelo reconhecimento da importância do Turismo: a) como fonte de divisas; b) pela necessidade de ampliar e modernizar o parque hoteleiro; c) pela importância em disciplinar as atividades do setor, atendendo às constantes solicitações do empresariado. A EMBRATUR representou, também, um marco na história da administração pública brasileira por ter sido a primeira empresa pública do País. Uma das primeiras contribuições para o setor turístico foi à concessão de incentivos financeiros, a isenção e diminuição de impostos para os segmentos, principalmente para os empreendimentos hoteleiros que, à época era deficitário qualitativa e quantitativamente. O surgimento da EMBRATUR estimulou a criação, em todos os estados e territórios, de organismos voltados ao desenvolvimento do Turismo, tais como secretarias, fundações e empresas, potencializando as gestões públicas voltadas à atividade em todo o país. Em que pesem as mudanças ocorridas nos cenários internos e externos, principalmente, aquelas relacionadas com a criação do Ministério do Turismo (MTur), a percepção dos impactos dessas mudanças foi destacada por todos que contribuíram na elaboração deste trabalho. Esta pesquisa além de trazer a história da Instituição, resgata a memória da EMBRATUR, ressaltando sua trajetória histórica no período de 1966 a 2006 sob a ótica de quem esteve à frente do processo operacional ao longo do período analisado. A metodologia adotada para desenvolvimento do estudo caracteriza-se como exploratória descritiva e documental. Pelas informações levantadas concluiu-se que no período considerado a EMBRATUR desenvolveu projetos relevantes que deram forma à estrutura da atividade turística nacional, tal como ela se apresenta hoje, bem como à promoção, no âmbito nacional e internacional.

Palavras-chave: EMBRATUR; Historia do Turismo no Brasil; Políticas Públicas; Gestão do Turismo. 


\begin{abstract}
This study presents the history of EMBRATUR - The Brazilian Tourist Board from 1966 to 2006, emphasizing its contribution to the Brazilian tourism industry's development. EMBRATUR was created due to the recognition of tourism importance as a source of wealth, development and discipline to the tourism sector in the economy. The Brazilian Tourism Board also represented a mark on the history of Brazil's public administration, since it was the first public company in the country. One of its first contributions to the tourism was the concession of financial incentives, the exemption and reduction of the taxes to the segments, especially to the hotel chain. The Uprising of EMBRATUR stimulated the emersion, of organisms interested on the development of the Brazilian tourism, such as Tourism Secretaries, Regional tourist Boards and tourism related companies, optimizing Brazil's public administration to this sector. Regarding the changes on the internal and external scenarios, specially the ones related to the creation of the Ministry of Tourism (MTur), the perception of these change impacts was accentuated by every person responsible to the elaboration of this work. This paper not only brings up the history of the Institution but also rescues the memory of EMBRATUR, enhancing its history along the period that ranges from 1966 to 2006 through the point of view of the one who was on the front line of the operational process during the period analyzed in this research.The methodology used to the development of this research is characterized as exploratory, descriptive and documental. The information collected led to the conclusion that during the target period, EMBRATUR developed substantial projects which gave form to the structure of the present national tourist activity as well as its promotion in the national and international communities.
\end{abstract}

Keywords: EMBRATUR; History of Tourism in Brazil; Public Policies; Tourism Management 


\section{LISTA DE FIGURA, GRÁFICO E TABELA}

FIGURA - Figura 1 - Pirâmide de necessidades básicas de Maslow ....... 8

TABELA - Tabela 1 - Turismo: Panorama 2020 ................................. 13

GRÁFICO - Gráfico 1 - Turismo no Mundo ............................................ 14 


\section{LISTA DE ABREVIATURAS E SIGLAS}

ABEOC - Associação Brasileira das Empresas Organizadoras de Congressos e Convenções ABIH - Associação Brasileira da Indústria de Hotéis

ABRACEF - Associação Brasileira dos Centros de Convenções e Feiras

ABRATT - Associação Brasileira dos Transportadores Exclusivos de Turismo

AHT - Associação de Hotéis de Turismo - (extinta)

BNDES - Banco Nacional de Desenvolvimento Social

CEBITUR - Centro Brasileiro de Informações Turísticas

CEE - Comunidade Econômica Européia

CNTur - Conselho Nacional do Turismo

COMBRATUR - Comissão Brasileira de Turismo

CONENTUR - Comissão Nacional de Entidades de Turismo

ECO 92 - Segunda Conferência Mundial para o Meio Ambiente e Desenvolvimento

EMBRATUR - Instituto Brasileiro de Turismo

FAAP- SP - Faculdade de Comunicação de Comunicação

FENACTUR - Federação Nacional de Turismo

FINOR - Fundo de Investimentos do Nordeste

FNHBRS - Federação Nacional de Hotéis, Restaurantes, Bares e Similares.

FNO - Fundo Constitucional de Financiamento do Norte

FUNGETUR - Fundo Geral de Turismo

IBRATEC - Instituto Brasileiro de Turismo, Exposições e Certames

INDA - Instituto Nacional de Desenvolvimento Agrário 
M.R.E - Ministério das Relações Exteriores

MIC - Ministério da Indústria e do Comércio

MTur - Ministério do Turismo

OMT - Organização Mundial do Turismo

PLANO AQUARELA - Marketing Turístico Internacional do Brasil

PLANTUR - Plano Nacional de Turismo

PNMT - Programa Nacional de Municipalização do Turismo

PRODETUR Nordeste - Programa de Desenvolvimento do Turismo Região Nordeste

PRODETUR Sul - Programa de Desenvolvimento do turismo na Região Sul

SUPRA - Superintendência de Reforma Agrária

UIOOT - União Internacional dos Organismos de Turismo

WTTC - World Travel \& Tourism Council

IATA - International Air Transport Association 


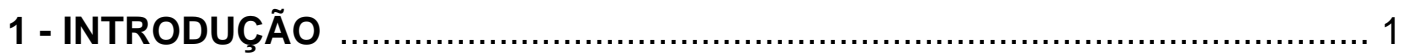

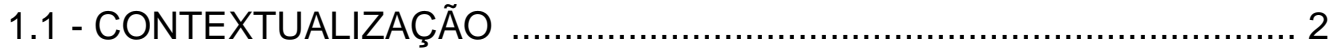

1.2 - DEFINIÇÃO DO TEMA E JUSTIFICATIVA …...................................... 3

1.3 - APRESENTAÇÃO DO PROBLEMA …............................................ 4

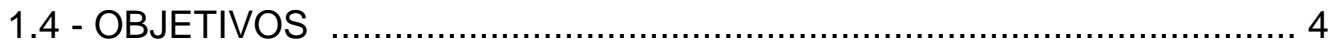

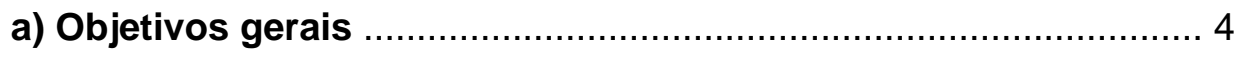

b) Objetivos específicos …..................................................... 4

1.5 - ORGANIZAÇÃO DO TRABALHO ................................................. 5

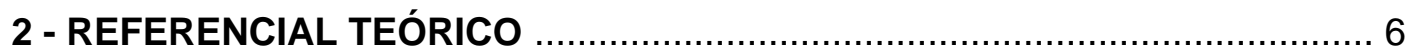

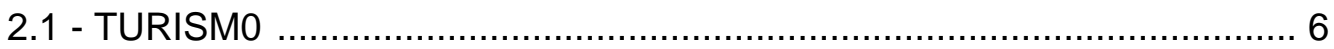

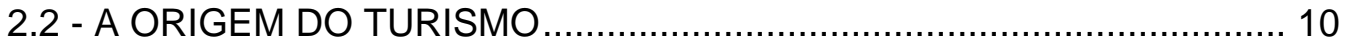

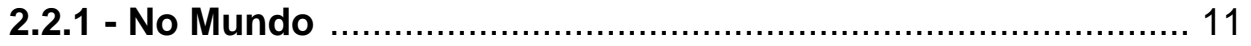

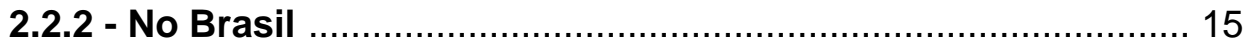

2.2.2.1 - Política de desenvolvimento turístico no Brasil................ 18

2.2.2.2 - Planejamento turístico no Brasil .................................... 23

2.2.2.3 - Políticas Públicas de Turismo ............................................. 25

2.3 - MARKETING NA ATIVIDADE TURÍSTICA ....................................... 27

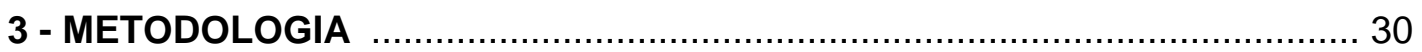

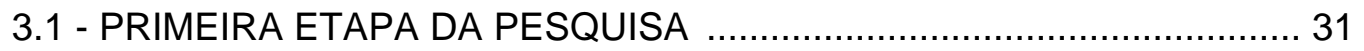

3.2 - SEGUNDA ETAPA DA PESQUISA ….......................................... 32

3.2.1 - Instrumento de coleta de dados ....................................... 33

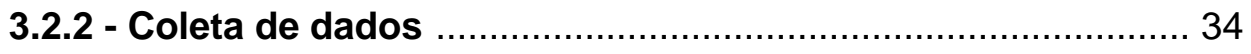

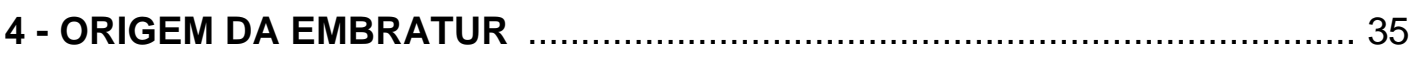

4.1 - OS DEZ PRIMEIROS ANOS DA EMBRATUR ................................... 45

4.2 - OS VINTE ANOS DA EMBRATUR................................................. 50

4.3 - A EMBRATUR NAS DUAS ÚLTIMAS DÉCADAS .............................. 61

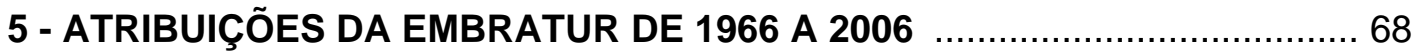

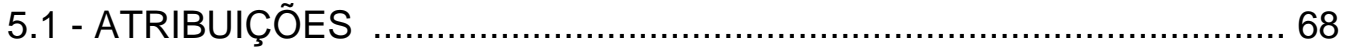

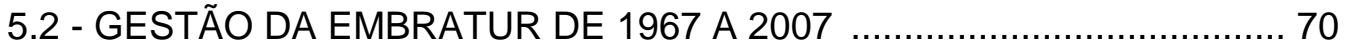

6 - A TRAJETÓRIA DA EMBRATUR NA VISÃO DE LIDERANÇAS,

DIRIGENTES E FORMADORES DE OPINIÃO DA ÁREA TURÍSTICA .......... 79

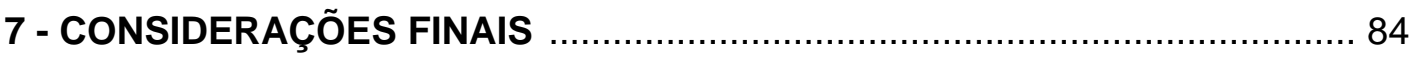


REFERENCIAL BIBLIOGRÁFICO 87

APÊNDICES 92

APÊNDICE I - Modelo de Correspondência e Questionários Aplicados 93

APÊNDICE II - Quem ajudou a fazer a história da EMBRATUR. 96

ANEXOS 100

ANEXO I - Leis e Decretos-Leis 101

ANEXO II - Primeiras folheterias da Embratur 102

ANEXO III - Fotos de ex-presidentes 103

ANEXO IV - Campanhas promocionais do período de 1987/1988 104

ANEXO V - Publicação da Embratur de 1969 105

ANEXO VI - Foto da Sede no Rio de Janeiro 106

ANEXO VII - Resultados do Turismo período 1966 a 2006 107 


\section{1 - INTRODUÇÃO}

O Turismo no Brasil atravessa um momento de transformações e seu desempenho tem sido bastante positivo no que se refere à contribuição ao crescimento econômico. Tal contribuição pode ser creditada ao trabalho que a EMBRATUR vem realizando desde sua criação com uma postura que visa auxiliar o trade turístico para o posicionamento do Turismo nacional frente ao mundial.

Na década de 60 e 70, o setor de Turismo era apenas um coadjuvante na economia e, hoje, com a facilitação do acesso aos meios de transportes e de comunicação, o setor alcançou níveis de movimentação financeira nunca alcançada, estando entre os principais setores da economia (MINISTÉRIO DO TURISMO, Turismo no Brasil - 2007/2010, 2006).

Esse estudo teve como objetivo principal apresentar a trajetória histórica da EMBRATUR - Instituto Brasileiro de Turismo no período de 1966 a 2006, ressaltando sua contribuição para o desenvolvimento da indústria do Turismo no Brasil, no mesmo período. Com base em uma abordagem histórica, procurou-se mapear a trajetória da EMBRATUR analisando e apresentando as perspectivas de lideranças das entidades de classe do setor, jornalistas especializados em Turismo, dirigentes e servidores que ocuparam posições de destaque, na Instituição. Buscou-se também resgatar a partir de uma pesquisa documental, a memória do órgão gestor do Turismo nacional, ressaltando seu valor didático e informativo, visto que vivenciamos um momento histórico de grandes transformações tecnológicas e sócio-culturais, nas quais o Turismo possui um papel primordial.

Vale destacar que o tema "Trajetória Histórica da EMBRATUR", não foi abordado antes por nenhum autor da área de Turismo, isso torna escassa a bibliografia sobre o assunto e em geral faz com que a história da época seja contada por pessoas que não tiveram a oportunidade de vivenciar o dia a dia da instituição, distorcendo os fatos reais. 
Este fato nos motivou a escrever sobre o assunto e este trabalho é, portanto, uma iniciativa para se resgatar um pouco de uma história que se perdeu no tempo, devido à falta de interesse em sua preservação.

Ao analisar as realizações, em termos de desenvolvimento e profissionalização da atividade, pretende-se fornecer subsídios aos planejadores do Turismo, em nível federal, estadual e municipal, quanto aos resultados que se podem esperar das ações de estímulo ao desenvolvimento, a partir da experiência da EMBRATUR.

\section{1 - CONTEXTUALIZAÇÃO}

O Turismo é um dos setores da atividade econômica que vem apresentando maior expansão, diante da abertura do mercado global, visto que o mundo encontra-se em constantes transformações assumindo cada vez mais um papel de maior importância no desenvolvimento do país, permitindo a integração de soluções, nos campos econômicos, social, político, cultural e ambiental, com um comportamento e uma prática pautados por padrões éticos concretos e obediência aos princípios gerais contidos no Código Mundial da Ética no Turismo da Organização Mundial do Turismo. (MINISTÉRIO DO TURISMO, Turismo no Brasil - 2007/2010, 2006).

É sabido o quanto o governo tem investido no setor, desde a criação do Ministério do Turismo, com isso, a EMBRATUR vem tendo o maior orçamento da sua história, possibilitando um investimento mais direcionado à divulgação e comercialização do país no exterior.

Mesmo assim, segundo o Marketing Turístico Internacional do Brasil Plano Aquarela, (estudo feito pela EMBRATUR, sob consultoria da Chias Marketing e ferramenta estratégica para alavancar o objetivo de impulsionar o Turismo), ressalta que, em relação aos países concorrentes, o orçamento brasileiro é ínfimo, pois é alocado em Reais e a desvalorização do câmbio gera uma queda substancial nos investimentos promocionais. 
No entanto, para que se possam alcançar as metas previstas no Plano Nacional de Turismo, o Plano Aquarela ressalta que o orçamento para Turismo deve ser revisto. (MINISTÉRIO DO TURISMO/EMBRATUR, Marketing Turístico Internacional do Brasil - Plano Aquarela, 2005).

\section{2 - DEFINIÇÃO DO TEMA E JUSTIFICATIVA}

O tema "Memória do Turismo: Trajetória Histórica da EMBRATUR no período de 1966 a 2006", escolhido para o desenvolvimento deste trabalho, se fez principalmente, devido à contribuição dada pela instituição para o desenvolvimento do Turismo nacional.

Devido aos problemas decorrentes da inundação do subsolo da sede da empresa no Rio de Janeiro, ocorrida em fevereiro de 1988, e sua transferência da para Brasília, em 1992, houve muitas dificuldade em resgatar a memória documentada da empresa, que ficou perdida no tempo. A forma encontrada para se ter acesso a essas informações, foi por meio da memória vivenciada por diversos funcionários (aposentados, ativos e ex-funcionários) da empresa.

O trabalho realizado pela EMBRATUR nos últimos 40 anos tem conseguido alcançar um melhor posicionamento do Turismo no mercado mundial.

Diante do exposto é incontestável a relevância do tema e da problematização levantada, partindo-se do princípio de que a EMBRATUR possa vir a contribuir ainda mais para o desenvolvimento do Turismo no Brasil. 


\section{3 - APRESENTAÇÃO DO PROBLEMA}

Coube a EMBRATUR a tarefa de estimular e coordenar o desenvolvimento da atividade turística, tendo em vista os benefícios econômicos e sociais que a atividade poderia proporcionar. É de se ressaltar que na execução dessa tarefa não contou com exemplos ou experiências que pudessem ser aproveitados para o contexto brasileiro. Dessa forma, as realizações foram fruto de decisões internas, ainda que eventualmente orientadas pelos dirigentes das entidades de classe do setor.

Cabe, portanto indagar e analisar os programas de maior relevância, bem como os entraves e dificuldades enfrentadas nessa ação pioneira de estruturação da atividade turística, no País.

\section{4 - OBJETIVOS}

\section{a) Objetivo Geral}

- Apresentar as ações e as principais contribuições da EMBRATUR para o desenvolvimento do Turismo no Brasil, no período de 1966 2006, com base em uma abordagem histórica.

\section{b) Objetivos Específicos}

- Mapear a trajetória histórica da EMBRATUR no período de 19662006;

- Mostrar como o Turismo tem se desenvolvido no Brasil nos últimos quarenta anos; 
- Analisar o papel da EMBRATUR, com base na visão dos principais representantes de entidades ligadas ao setor, ex-dirigentes e servidores do Instituto.

\section{5 - ORGANIZAÇÃO DO TRABALHO}

Quanto à estruturação, este trabalho está divido em sete seções da seguinte forma: a primeira seção faz uma introdução onde é destacada a contextualização do tema, que contribuiu para o direcionamento da pesquisa, os objetivos e a organização do trabalho.

A segunda seção consiste no referencial teórico e apresenta os conceitos de Turismo no Mundo e no Brasil (política e planejamento) destacando sua importância, e também é apresentado o marketing na atividade turística.

A metodologia da pesquisa está apresentada na terceira seção. Tratase de pesquisa exploratória, descritiva e documental.

A quarta seção apresenta a origem da EMBRATUR e sua participação, no decorrer destas 4 (quatro) últimas décadas.

A quinta seção consiste nas atribuições da EMBRATUR, destacando suas atividades e gestões.

A sexta seção apresenta a trajetória da EMBRATUR na visão de lideranças, dirigentes e formadores de opinião da área turística, que foram entrevistados.

Para finalizar, a sétima seção apresenta as principais considerais finais. 


\section{2 - REFERENCIAL TEÓRICO}

Nesta seção serão abordados alguns conceitos de Turismo, analisando os argumentos de alguns autores sobre esse tema. Será também, apresentada a história do Turismo, descrita por autores pesquisados, e relatada por membros de entidades de Turismo no Brasil.

\section{1 - Turismo}

O setor de Turismo vem obtendo destaque na economia mundial, principalmente por se tratar de um setor que abrange uma variedade de elementos materiais, que formam o conjunto de requisitos para realizar a atividade turística, ou seja, forma o sistema turístico (MINISTÉRIO DO TURISMO, Turismo no Brasil - 2007/2010, 2006).

O Turismo é hoje uma atividade considerada como marcante nos mais diversos segmentos da sociedade, permitindo que seus impactos sejam sentidos diretamente nas relações sociais, econômicas, culturais e ecológicas; tornando-se uma fonte importante de estudos exploratórios, onde conhecer a ampla esfera que abrange o cenário turístico é entender a atualidade (WAHAB, 1991).

Analisaremos, inicialmente, o conceito etimológico da palavra Turismo, que, como apresentado por Barreto (1999, p. 43), possui diferenças e tem duas origens distintas:

O conceito de Turismo surge no século XVII na Inglaterra, referido a um tipo especial de viagem. A palavra tour é de origem francesa (...), quer dizer volta e tem seu equivalente no inglês turn, e no latim tornare. O pesquisador suíço Arthur Haulot acredita que a origem da palavra está no hebraico Tur 
que aparece na Bíblia com o significado de viagem de reconhecimento.

A complexidade e abrangência do fenômeno turístico fazem com que seu estudo e definições sejam abordados de diferentes maneiras. De forma técnica, a Organização Mundial do Turismo (OMT), órgão representante da indústria turística mundial, adota um conceito prático: "deslocamento para fora do local de residência por período superior a 24 horas e inferior a 60 dias motivados por razões não econômicas". Essa definição, para Ignarra (2003), não serve para descrever a real magnitude do fenômeno Turismo, pois serve apenas para padronizar o conceito nos países membros da OMT.

A Organização Mundial de Turismo - OMT, na cartilha de segmentação do Turismo (2006, p. 4), conceitua Turismo como as atividades que as pessoas realizam durante viagens e estadas em lugares diferentes do seu entorno habitual, por um período inferior a um ano, com finalidade de lazer, negócios ou outros.

Ainda há o outro conceito da OMT, segundo Oliveira (2001), que classifica e identifica o Turismo como suas características essenciais e o distingue de outros fenômenos:

\footnotetext{
"Como sendo um fenômeno que ocorre quando um ou mais indivíduos se transladam a um ou mais locais diferentes de sua residência habitual, por um período maior que 24 horas e menor que 180 dias, sem participar dos mercados de trabalho e capital dos locais visitados" (conceito extraído do livro Turismo e Desenvolvimento - Planejamento e Organização, de Oliveira, 2001, p. 35).
}

Segundo Lage e Milone (2000, p. 26), "o que se observa do Turismo atual é a existência de uma rica e grandiosa indústria, que se relaciona com todos os setores da economia mundial e que deverá continuar atendendo aos 
interesses da humanidade nos próximos milênios", comprovando a importância da atividade.

Para Ignarra (1999), o Turismo iniciou quanto o homem deixou de ser sedentário e passou a viajar, motivado pelo comércio com outros povos. Portanto, é aceitável admitir que o Turismo de negócios antecedeu ao de lazer; assim como os Turismos de aventura, de saúde e religioso são datados de milhares de anos antes de Cristo.

Em geral, as pessoas se deslocam motivadas pelos mais distintos motivos e para os mais variados lugares. No entanto, o estudo dessas motivações iniciou-se somente após a Segunda Guerra Mundial, quando o movimento turístico começou a ganhar força econômica e a estruturar-se. A industrialização propiciou o aumento do tempo livre dos empregados que, como já não passavam mais tantas horas no trabalho, passaram a ter mais tempo livre para dedicar ao lazer e, conseqüentemente, para as viagens.

De acordo com a teoria comportamental de Maslow (apud Vaz,1999; p. 42):

A ânsia pelo lazer encontra-se acima das necessidades de auto-realização, auto-estima e aceitação social. Porém, essas necessidades só seriam priorizadas após o suprimento das necessidades fisiológicas e de integridade física. Essas necessidades são analisadas na pirâmide proposta por Maslow. (Figura 1). 
Figura 1

\section{Pirâmide de necessidades básicas de Maslow}

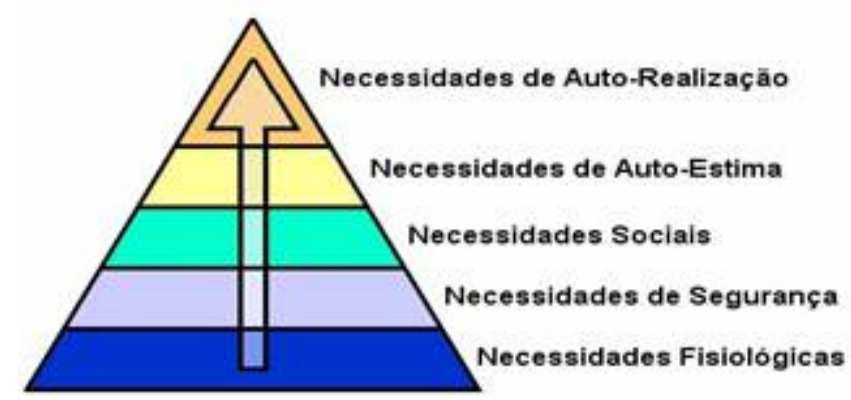

Fonte: Maslow apud Vaz (1999; p. 42)

Como mostrado na Figura 1, a pessoa para poder dispor-se ao lazer, deve primeiramente sentir-se bem e segura fisicamente, ou seja, ter suprida sua fome, sede, cansaço, insegurança para, só então, buscar algo que lhe dê prazer.

Não há uma definição única do que seja Turismo, ele se transforma de acordo com as necessidades humanas, assim sua definição torna-se dinâmica e surge de acordo com o comportamento sócio-cultural e econômico da humanidade (OTTO, 2001, p. 19)

Do ponto de vista de Andrade (1992), que apresenta uma perspectiva estrutural, colocando o Turismo como prestador de serviços e que, no caso, torna-se mais adequado ao tema do trabalho proposto.

O Turismo é o conjunto de serviços que tem por objetivo o planejamento, a promoção e a execução das viagens, e os serviços de recepção, hospedagem e atendimento aos indivíduos e aos grupos, fora de suas residências habituais. 
O setor de Turismo envolve uma mistura de elementos materiais, que são os transportes, os alojamentos, as atrações e as diversões disponíveis. Os fatores psicológicos seriam desde uma simples fuga da rotina, passando pela concretização de um sonho ou fantasia, até simplesmente a recreação, o descanso. Devem-se incluir também os interesses sociais, históricos, culturais e econômicos.

Turismo, além de promover a interação e aproximação de pessoas de culturas e locais diferentes, é negócio, geração de renda e empregos diretos e indiretos. Trata-se de uma atividade econômica que pertence ao setor terciário e é composto de um conjunto de serviços (meios de hospedagem, transporte, gastronomia, entretenimento, entre outros) que se vendem aos turistas.

Devido ao seu desenvolvimento e maior acessibilidade, cada vez mais pessoas em todo mundo encontram nas viagens a melhor alternativa para preencher seu tempo livre, proporcionando assim boas perspectivas para 0 Turismo.

\section{2 - ORIGEM DO TURISMO}

Vários documentos antigos e atuais sobre a história do Turismo tentam comprovar com muita polêmica e discussão, principalmente pela diversidade de informações que são sugeridas a respeito do marco inicial das viagens turísticas que existem vários motivos que obrigam o homem a se deslocar.

As viagens sempre estiveram presentes na vida do homem e o Turismo vem se expandido no mundo há muito tempo.

De acordo com Dias (2003, p. 4): 
O fenômeno das viagens não é novo na história da humanidade; desde que se formaram as primeiras sociedades o homem sempre viajou pelos mais diversos motivos: econômicos, políticos, sociais, culturais, esportivos. Nas primeiras sociedades humanas os deslocamentos se destinavam à busca de alimentos, através da caça e das coletas de frutos e sementes.

Nota-se que o Turismo está se desenvolvendo cada vez mais no mundo inteiro e que, além dos aspectos positivos do lazer, trás, ainda, um significativo crescimento à economia de muitos países.

Segundo alguns autores "viajar a Turismo é algo diferente, pois exige estrutura própria e algum planejamento. Além disso, quem viaja abandona temporariamente sua habitação, mas volta para seu local de residência após o período da viagem".

\subsection{1 - No Mundo}

Um movimento que teve grande importância econômica e social para o desenvolvimento do Turismo foi a Revolução Industrial (segunda metade do século 18 e primeira metade do século 19), quando o Turismo teve um momento significativo na sua evolução e passou a ser conhecido tal como é atualmente.

Entre os benefícios trazidos pela Revolução Industrial, o desenvolvimento do transporte ferroviário, para transporte de passageiros, foi também determinante para o desenvolvimento do Turismo, como no exemplo dado por Barreto (1999), quando a ferrovia Liverpool-Manchester preocupou-se com o passageiro, antes de preocupar-se com a carga.

A evolução dos transportes também teve seu ponto alto no desenvolvimento da navegação de alto-mar. Barreto (1999) diz que esse desenvolvimento se deu graças à necessidade do transporte de imigrantes e, 
principalmente, pela necessidade de uma comunicação entre a Inglaterra e os Estados Unidos (colônia da Inglaterra). Comunicação que também muito se desenvolveu na Revolução Industrial e tornou-se uma importante contribuição na evolução do Turismo, a partir do momento em que muito se descobriu sobre os destinos, através de inúmeros meios de comunicação.

Barreto (1999, p. 48) ressalta que nesse período a sociedade esteve marcada pelas conseqüências da melhora nos transportes nas áreas de comércio, indústria, serviços e na realocação de mão-de-obra. As pessoas deixaram de trabalhar no campo e passaram a fazê-lo nas indústrias de manufaturas e nos transportes. Surgiu uma classe média que passou a ter melhores salários e que se tornou consumidora de atividades de entretenimento, como futebol e corrida de cavalos.

Para Pires (2001), foi no decorrer da Revolução Industrial que se prepararam as condições para o surgimento do Turismo moderno, principalmente pelo fato de muito ter se usufruído das invenções ocorridas nessa época.

\begin{abstract}
A revolução nos transportes, a complexidade social em todas as suas variáveis, ocorridas com o fortalecimento das cidades e o prestígio da economia urbana em expansão, além da relativa paz, fizeram a base do Turismo moderno. (PIRES, 2001, p. 05).
\end{abstract}

A segurança propiciada pelo estabelecimento da polícia regular; a salubridade, pelo tratamento das águas e instalação de esgotos em várias cidades européias; a redução do número de analfabetos, que elevou os números de leitores de jornais, permitindo acesso à informação, estimulando o interesse por viajar, foram os fatores que contribuíram para o desenvolvimento do Turismo no século 19.

As primeiras viagens organizadas, amparadas pelo trabalho de um agente de viagem, surgiram no século 19 . Também foi neste período que a 
atividade turística no Brasil foi marcada pelas viagens de trem e a internacional pelas viagens de navio.

Com o avanço dos modos de produção, melhoria dos meios de transporte e da vida nas cidades, o Turismo ganhou força e se tornou um fenômeno mundial de massas, que continua a crescer até hoje.

$\mathrm{Na}$ história do Turismo, ainda se pode destacar outro grande incremento nas viagens, ocorrido após a Revolução Industrial, no século XVIII; que antecede ao Turismo moderno. Thomas Cook primeiro agente de viagem do mundo, foi um dos grandes percussores do Turismo..

Quando organizou o primeiro tour de viagem em larga escala, conduzindo 500 pessoas para a localidade de Leicester, Thomas Cook deu sua primeira e grande arrancada. Foi ele, também, o primeiro a se utilizar de campanhas publicitárias e de marketing para atrair clientes e tornar acessível à viagem e o Turismo a pessoas da classe trabalhadora e da classe média; produzindo, assim, o Turismo de massa: pessoas com o mesmo comportamento, visitando os mesmos lugares e consumindo as mesmas coisas. Também foi responsável por contratar os primeiros guias de Turismo em suas viagens e por criar um cupom de hotel, que nos dias de hoje é conhecido como voucher.

Segundo dados da OMT - Organização Mundial do Turismo, o volume turístico internacional em 2003 (Plano Aquarela, 2005), foi de aproximadamente 700 milhões de pessoas (sendo considerada turista a pessoa que realiza uma viagem para além das fronteiras territoriais de seu próprio país), gerando uma receita da ordem de 483 bilhões de dólares. A previsão da OMT é de crescimento do fluxo para os próximos anos. Estima-se que em 2010 o número de turistas deverá superar a marca de 1 bilhão e em 2020 esse número chegará a 1,5 bilhão.

Tanto os números de 2003 como os indicadores para 2004 foram animadores, todos os dados apontavam para uma retomada da curva de crescimento e confirmando, na prática, a viabilidade das estimativas feitas pela OMT para o ano de 2010 (MINISTÉRIO DO TURISMO/EMBRATUR, PLANO 
AQUARELA - Marketing Turístico Internacional, 2005). Pode-se conferir os dados na Tabela 1 a seguir.

Tabela 1

Turismo: Panorama 2020

Previsiones mundiales y perfiles de los segmentos de mercado

\section{Tendências do Turismo Mundial}

\begin{tabular}{|l|c|c|c|c|c|c|}
\hline & 1990 & 1995 & 2002 & 2003 & $\begin{array}{c}\text { Previsão } \\
2010\end{array}$ & $\begin{array}{c}\text { Previsão } \\
2020\end{array}$ \\
\hline MUNDO & & & & & & \\
\hline & 457,2 & 565,4 & $\mathbf{7 1 4 , 6}$ & $\mathbf{6 9 4}$ & $\mathbf{1 . 0 0 6 , 0}$ & $\mathbf{1 . 5 6 1 , 0}$ \\
\hline AMÉRICAS & $\mathbf{9 2 , 8}$ & 108,9 & $\mathbf{1 2 0 , 0}$ & $\mathbf{1 1 2 , 4}$ & $\mathbf{1 9 0 , 0}$ & $\mathbf{2 8 2 , 0}$ \\
\hline AMÉRICA DO SUL & $\mathbf{7 , 9}$ & $\mathbf{1 1 , 8}$ & $\mathbf{1 2 , 5}$ & $\mathbf{9 , 3}$ & $\mathbf{2 6 , 9}$ & $\mathbf{4 2 , 8}$ \\
\hline BRASIL & & & & & & \\
\hline
\end{tabular}

Fonte: OMT, 2004. Com informações fornecidas pelos países membros (Milhões de turistas internacionais).

A Europa segue como o principal mercado turístico do mundo, correspondendo há quase $2 / 3$ do comércio mundial do setor. A mudança mais sensível foi na segunda colocação: devido ao crescimento registrado nos últimos anos a Ásia elevou sua presença no mercado. Em 2003 o continente asiático superou as Américas em $1 \%$ e ficou com a $2^{\mathrm{a}}$ colocação, recebendo $17 \%$ do total de turistas internacionais, contra $16 \%$ do continente americano (MINISTÉRIO DO TURISMO/EMBRATUR, PLANO AQUARELA - Marketing Turístico Internacional, 2005).

Como pode ser visto no Gráfico 1, as estimativas da OMT também são otimistas, segundo o Barômetro do Turismo Mundial, publicado pela entidade em outubro 2004. As expectativas são de que o crescimento do Turismo no continente americano deva obter um crescimento superior a $12 \%$ em relação a 
2003 (MINISTÉRIO DO TURISMO/EMBRATUR, PLANO AQUARELA Marketing Turístico Internacional, 2005).

\section{Gráfico 1}

Turismo no Mundo

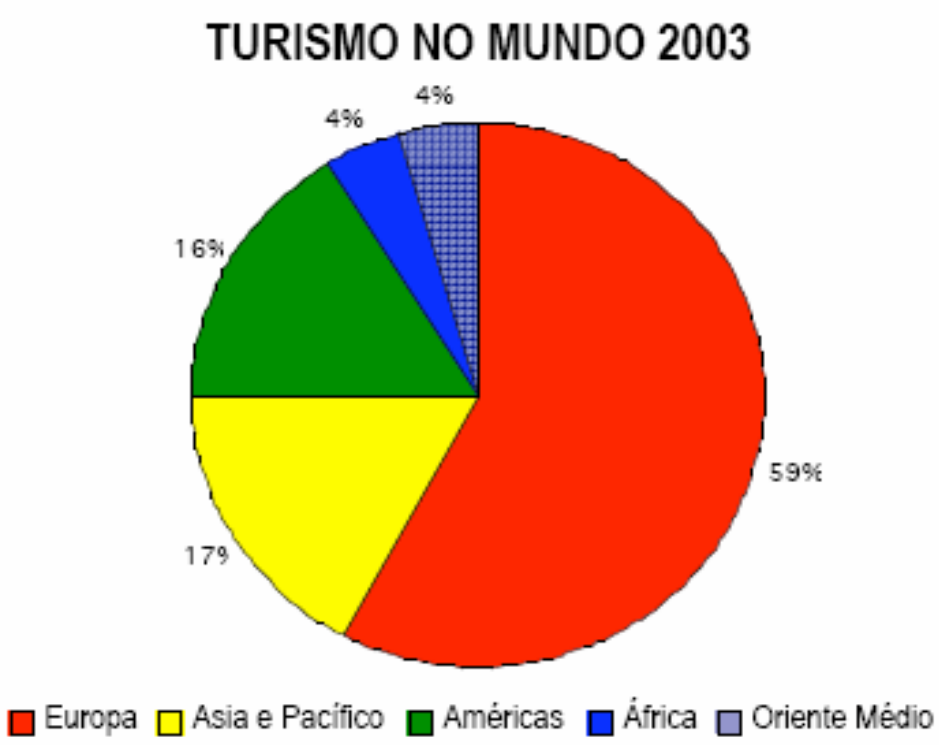

Fonte: Barômetro OMT del Turismo Mundial. 2a edição, no. 2, julho de 2004.

\subsection{2 - No Brasil}

Segundo Pires (2001), o Brasil teve um importante desenvolvimento com a chegada de estrangeiros, desde a época da vinda da Família Real, em 1808. A partir daí, viajantes eram comuns no país, mas encontravam deficiências em locais para hospedagem.

Trigo (apud IGNARRA, 2003, p.19-20) fala sobre o precário sistema de hospedagem no Brasil. 
Em 1787, o cirurgião inglês John White, cansado de percorrer com outros passageiros de seu navio as ruas estreitas do Rio de Janeiro, considerou o maior incômodo não achar cafés ou hotéis, onde pudessem tomar refresco ou passar uma ou duas noites em terra.

Ainda sobre o precário sistema de hospedagem no Brasil, Pires (2001, p.50) comenta:

Não obstante todas as transformações ocorridas, em relativamente curto espaço de tempo, demoraram ainda muitos anos para que as citadas novidades fizessem parte da vida da Corte. A palavra "hotel", embora não fosse desconhecida no Rio de Janeiro na primeira década do século XIX, talvez não passasse de um eufemismo para designar uma simples estalagem.

A hotelaria ganhou ares de modernidade apenas em 1870, quando, de acordo com Pires (2001), não houve somente a preocupação "com os aspectos ligados ao pernoite, mas também em agradar ao hóspede ou àqueles que se utilizava de seus serviços", oferecendo serviços como banhos salutares e pratos da cozinha francesa.

Pires (2001) fala também sobre a precariedade dos transportes, quando viajantes chegavam ao país e reclamavam desde os altos preços cobrados, às grandes distâncias que eram percorridas. Para esse problema, a solução só apareceu em 1870, ano que marcou a evolução do transporte urbano, com o inicio da operação da primeira linha de bondes, no Rio de Janeiro.

Ignarra (2003) também atenta para esse fato, quando na segunda metade do século XIX, pela ação do Visconde de Mauá, desenvolveram-se os transportes movidos a vapor e em 1858 foi inaugurado o primeiro trecho ferroviário, ligando o Rio de Janeiro a Petrópolis. 
Para Ignarra (2003), essa evolução dos transportes no Brasil propiciou um incremento de deslocamento, principalmente para o Rio de Janeiro, lugar onde as pessoas mais freqüentavam, visto que era a cidade de maior importância no Brasil, pois nela estava instalada a Corte.

Ainda no pioneirismo na Corte, em 1885, foi inaugurado o trem para subir ao Corcovado. De acordo com Ignarra (2003), este foi o primeiro atrativo turístico a receber uma infra-estrutura. Pires (2001) também fala que os viajantes estrangeiros faziam paradas quase obrigatórias no Rio de Janeiro em lugares como o Jardim Botânico, a Tijuca e o próprio Corcovado.

Porém, já no século XX, Barreto (1999) acredita que foi o transporte aéreo o fator mais importante na história do Turismo mundial. Durante a Segunda Guerra Mundial, o Turismo ficou paralisado, conseguindo retomar seu crescimento a partir de 1945, em função da aviação.

Em 1949 foi vendido o primeiro pacote aéreo e, a partir de 1957, o Turismo aéreo começou a ser preferido ao Turismo de cruzeiros, pelo tempo ganho no deslocamento e pela introdução de tarifas turísticas econômicas por avião. (BARRETO, 1999, p. 55)

Sobre a hotelaria no século XX, Barreto (1999, p. 55) cita:

Antigamente os melhores hotéis estavam nos centros das cidades, mas com o crescimento do Turismo automotor, (...) construíram-se hotéis com estacionamento (...). A atmosfera familiar do hotel antigo, ou da hospedaria, deixou de ser do gosto dos turistas.

A década de 60 foi a mais importante para a história do Turismo no Brasil no século XX. Ignarra (2003) destaca que começa a existir uma preocupação mais concreta por parte do governo brasileiro, com a criação dos primeiros instrumentos de regulamentação da atividade: o Conselho Nacional 
do Turismo (CNTur), o Fundo Geral de Turismo (FUNGETUR) e a Empresa Brasileira de Turismo (EMBRATUR).

Segundo Decreto-Lei $n^{\circ}$. 55/66 (Anexo 1), que criou a EMBRATUR, suas principais atribuições, à época, foram:

- Fomentar e financiar diretamente iniciativas, planos, programas e projetos que visassem o desenvolvimento da indústria do Turismo.

- Estudar de forma sistemática e permanente o mercado turístico, de maneira a obter os dados necessários para o seu controle técnico.

- Organizar, promover e divulgar as atividades ligadas ao Turismo.

- Registrar e fiscalizar as empresas do setor.

\subsubsection{1 - Política de Desenvolvimento Turístico no Brasil}

Para melhor analisar o desenvolvimento e o desempenho do Turismo no Brasil, é de suma importância destacar o papel da EMBRATUR (antiga Empresa Brasileira de Turismo). Desde a sua criação, em 1966, percebe-se uma maior preocupação com o Turismo no Brasil, por parte do governo.

Em âmbito mundial, o Turismo tem se constituído em um elemento propulsor do desenvolvimento e do crescimento econômico. Cabe ao poder público o papel de regulamentar e fiscalizar as atividades turísticas dentro de um país, devendo estabelecer os mecanismos necessários para preservar as condições que sustentam a atividade.

A elaboração das Políticas de Desenvolvimento Turístico enquadra-se nas responsabilidades atribuídas ao poder público, pois este deve nortear e coordenar o desenvolvimento turístico. Deriva daí que o poder público possui 
responsabilidades quanto ao processo de elaboração do produto turístico e sua comercialização.

Na execução da Política, segundo Kotler, Haider e Rein (1994), o seu papel está em proporcionar o que é básico, ou seja, a infra-estrutura, principalmente nas modalidades de transporte, comunicação e saneamento. Com isso oferecer qualidade de vida da população local e dos visitantes. Cabe ao poder público, também, assegurar que os turistas os turistas despertem e mantenham o interesse por determinado produto ou destino.

Em relação ao processo de comercialização, a esfera pública assume atribuições que envolvem o planejamento, a coordenação e a integração de todos aqueles que intervêm no andamento da promoção e venda da oferta turística.

Corresponde ao poder público a realização das atividades de promoção, expansão e captação de correntes turísticas; de regulamentação normativa do funcionamento das empresas; de estímulo e facilidade ao desenvolvimento da oferta turística mediante determinadas planificações, (...) (CASTELLI, 2001, p. 52).

A primeira diretriz política para o Turismo no Brasil surgiu no início do Decreto-lei 55/66 (Capítulo 1 - Da Política Nacional do Turismo), o mesmo decreto que criou a EMBRATUR. Depois disto, esta política vem sendo adequada às diretrizes da política econômica em vigor e às tendências do mercado. As mudanças atingiram também a denominação dessas diretrizes ao longo do período, sendo chamadas de Diretrizes e Metas ou de Plano.

Segundo o Decreto-Lei nº 55/66, que criou a EMBRATUR, a Política Nacional do Turismo tinha como principais metas:

- Fomentar e financiar diretamente iniciativas, planos, programas e projetos que visassem o desenvolvimento da indústria do Turismo; 
- Estudar de forma sistemática e permanente o mercado turístico, de maneira a obter os dados necessários para seu controle técnico;

- Organizar, promover e divulgar as atividades ligadas ao Turismo;

- Registrar e fiscalizar as empresas do setor.

Em 1994, os objetivos da Política Nacional de Turismo, segundo Boletim da Embratur (1988), eram:

- Democratizar o acesso ao Turismo Nacional pela incorporação de diferentes segmentos populacionais, de forma a contribuir para a elevação do bem-estar das classes de menor poder aquisitivo;

- Reduzir as disparidades sociais e econômicas de ordem regional, através do crescimento da oferta de empregos e melhor distribuição de renda;

- Aumentar os fluxos turísticos, a taxa de permanência e o gasto médio dos turistas estrangeiros no país, mediante maior divulgação do produto brasileiro em mercados potenciais emissivo, em nível internacional;

- Difundir novos pontos turísticos, com vistas a diversificar os fluxos entre as Unidades da Federação e beneficiar especialmente as regiões de menor nível de desenvolvimento;

- Ampliar e diversificar os equipamentos e serviços turísticos, adequando-os às características sócio-econômicas regionais e municipais; 
- Estimular o aproveitamento turístico dos recursos naturais e culturais, que integram o patrimônio turístico, com vistas à sua valorização e conservação;

- Estimular a criação e implantação de equipamentos destinados às atividades de expressão cultural, serviços de animação turística e outras atrações com capacidade de retenção e prolongamento da permanência dos turistas;

- Estimular a competitividade do setor, como um todo, através da melhoria da qualidade e da produtividade de seus agentes privados e estatais.

Com a criação do Ministério do Turismo, em 2003, as diretrizes para o setor estão consubstanciadas no Plano Nacional do Turismo 2003 - 2007, tendo como princípios orientadores a redução das desigualdades regionais e sociais, geração e distribuição de renda, geração de empregos e divisas para o país.

Os objetivos do Plano Nacional do Turismo são:

Objetivos gerais:

- Desenvolver o produto turístico brasileiro com qualidade contemplando nossas diversidades regionais, culturais e naturais;

- Estimular e facilitar o consumo do produto turístico brasileiro nos mercados nacional e internacional.

Objetivos específicos:

- Dar qualidade ao produto turístico;

- Diversificar a oferta turística;

- Estruturar os destinos turísticos;

- Ampliar e qualificar o mercado de trabalho; 
- Aumentar a inserção competitiva do produto turístico no mercado Internacional;

- Ampliar o consumo do produto turístico no mercado nacional;

- Aumentar a taxa de permanência e gasto médio do turista

Já suas metas são:

- Criar condições para gerar 1.200 .000 novos empregos e ocupações;

- Aumentar para 9 milhões o número de turistas estrangeiros no Brasil;

- Gerar 8 bilhões de dólares em divisas;

- Aumentar para 65 milhões a chegada de passageiros nos vôos domésticos;

- Ampliar a oferta turística brasileira, desenvolvendo no mínimo três produtos de qualidade em cada Estado da Federação e Distrito Federal;

O Instituto Brasileiro de Turismo - EMBRATUR passou por uma reestruturação, deixando de traçar políticas públicas para o setor, passando a ser responsável apenas pela promoção, marketing e apoio à comercialização dos produtos, serviços e destinos brasileiros no exterior.

Com base nas metas do Plano Nacional de Turismo, é possível observar que a atividade turística no Brasil teve bom desempenho nos últimos anos, em que pese à falência da principal companhia área nacional. Face ao barateamento do transporte aéreo e o aumento da renda per capita da população, acredita-se que a atividade continuará a crescer ainda mais nos próximos anos. 
Vale observar que à EMBRATUR cabe promover e coordenar o desenvolvimento do turismo no Brasil. No entanto, ela não tem ingerência nos preços praticados pelos empresários do setor ou sobre as características dos pacotes turísticos. Assim, ao setor privado cabe a responsabilidade pela efetivação da venda do produto turístico e, conseqüentemente pelo maior ou menor aporte de divisas, entrada de turistas e geração de empregos, fator esses interligados.

\subsubsection{2 - Planejamento Turístico no Brasil}

Em termos comparativos, o Brasil é ainda, um destino pouco conhecido, pois segundo dados da OMT - Organização Mundial do Turismo, ele ainda não consta na relação dos 10 primeiros do ranking mundial, apesar de ter sido registrada pela EMBRATUR a entrada de 5,4 milhões de turistas estrangeiros em 2005, o dobro do registrado em 1996, ano que entraram mais ou menos 2,7 milhões de turistas.

Considerando o potencial da Indústria do Turismo nacional, dadas às características privilegiadas do país, em termos de diversidades geográficas, clima, cultura, cidades históricas etc., o Brasil poderia encontrar-se entre os principais destinos turísticos do mundo.

Comparativamente, nas últimas décadas, alguns países asiáticos, que não ostentam as mesmas riquezas naturais e diversidade cultural, tornaram-se destinos prioritários do Turismo internacional.

Segundo pesquisa realizada pela empresa responsável na elaboração do Plano Aquarela, Chias Marketing (2005), para os operadores internacionais há vários motivos para o fraco desempenho da indústria turística nacional, incluindo: o elevado custo do transporte aéreo interno e internacional; os limites da infra-estrutura interna (aeroportos, estradas, hotéis, restaurantes, etc.); além da inadequação dos serviços das agências de viagens e operadores de Turismo locais. Criticam, também, a escassez de material informativo. Com 
efeito, os gastos com a divulgação do país, como destino turístico, estão muito aquém das recomendações da Organização Mundial do Turismo, onde, pelo menos, $2 \%$ da receita sejam investidas em publicidade.

No Brasil, os investimentos em Turismo, se comparados a alguns países, é muito pequeno e terá que ser revisto, para que se possa alcançar melhor posição no ranking mundial de países receptores de turistas.

No contexto da economia brasileira, o Turismo já vem assumindo um papel cada vez mais relevante, em 2006 figurando em $42^{\circ}$ lugar na pauta da receita turística cambial, com uma receita de $\cup \$ 4,3$ bilhões. No entanto, a participação do Brasil no Turismo mundial é inexpressiva, 0,67\% de chegadas internacionais em 2005, o que representa a $37^{a}$ posição no ranking mundial da OMT em 2006, posição essa bastante modesta em relação aos demais países.

No entanto, devemos ressaltar que a razão pela qual o Brasil não ocupa a posição que lhe caberia no mercado turístico mundial, deve-se ao fato de seu orçamento ser em Reais e a acentuada desvalorização do câmbio existente, até recentemente, gerar uma queda substancial no investimento promocional em relação aos paises concorrentes (MINISTÉRIO DO TURISMO/EMBRATUR, Plano Aquarela, Marketing Turístico Internacional, 2005).

Contudo, esta situação tende a mudar. Por um lado o Governo Federal tem demonstrado que está priorizando o Turismo, por meio da elevação da dotação orçamentária. Além disso, o setor passou a contar com a ajuda de múltiplos mecanismos de financiamento, BNDES - Banco Nacional de Desenvolvimento Social, do PRODETUR - Programa de Desenvolvimento do Turismo, que contribuiu para minorar as principais deficiências da infraestrutura turística do país. O setor privado também acompanha este esforço, com investimentos expressivos em hotéis e parques temáticos. Desta forma 0 Nordeste, por exemplo, possui condições iguais ou melhores do que a maioria dos destinos turísticos com atrativos semelhantes e internacionalmente renomados. (MINISTÉRIO DO TURISMO/EMBRATUR, Plano Aquarela, Marketing Turístico Internacional, 2005). 


\subsubsection{3 - Políticas Públicas de Turismo}

As políticas Públicas constituem-se no estabelecimento de caminhos que orientam decisões para que possam se realizar ações, tanto públicas como privadas, em busca de determinados objetivos. Elas possuem dois grandes desafios, a elaboração desta política onde buscam discutir os valores e verificar se a política está de fato implementada (PINTO apud BRASIL, 2007).

As Políticas Públicas existem em todas as áreas e tem a função de incluir as pessoas, que por algum motivo são menos favorecidas dentro de uma sociedade, onde elas possam interagir em conjunto sem nenhum tipo de exclusão, participar de atividades culturais, sociais, políticas, religiosas, ou seja, de igualdade para todos. Esta é a estratégia que os governos utilizam para garantir que todos os sujeitos estejam inseridos nas relações de troca do mercado capitalista (PINTO apud SCHERER, 2007).

Beni (2006, p.18) afirma que:

As Políticas Públicas de Turismo no Brasil sempre tiveram impacto sobre o setor propriamente dito e sobre Estados e Municípios, o que poderia justificar, em parte, desacertos acerca da ausência constante de uma orientação maior que indicasse explicitamente objetivos, metas, prioridades e metodologia na elaboração de projetos e programas.

O planejamento e a coordenação das Políticas Públicas devem ser centralizados em uma área específica, elaborando e implementando planos, e depois acompanhando e controlando os efeitos colaterais que essa política tem sobre a população local.

O autor ainda nos mostra que o nosso País ainda carece de Políticas Públicas efetivas que contribuam para a inserção eqüitativa de áreas menos dinâmicas. Existem Políticas Públicas para as populações mais pobres, mas 
precisam ser criadas Políticas Públicas para as regiões brasileiras que tem grande problema de estagnação econômica, de desenvolvimento. É preciso que a comunidade participe destas ações para o próprio conhecimento dos seus direitos e deveres, onde possam reunir todos os setores do Turismo, empresas para que juntas avaliem seus dados quantitativos e qualitativos para verificarem quais os problemas e como chegar até a solução deles (BENI, 2006).

O autor Dye (DYE apud PINTO, 2007, P.20) define Políticas Públicas como, "tudo aquilo que o governo decide fazer ou não", ou seja, o governo elabora sua agenda, escolhendo seus problemas, formula, define como resolver, e na hora da prática nada é feito. Neste caso então, temos a ação e inação do governo. As ações são todos os planos que o governo elabora ou pratica causando uma repercussão positiva na sociedade. Porém, a inação é tudo aquilo que não é colocado em prática, podendo ter uma repercussão negativa.

Existem também outras definições de Políticas Públicas, como esta do Ministério do Turismo que a define como:

"Um produto da atividade política, entendida esta como conjunto de mecanismo e procedimentos pelos quais o consenso se revela preferencialmente à coerção na resolução dos conflitos de poder e de interesses envolvendo bens públicos"

"A Organização Mundial do Turismo (OMT) é a principal organização internacional criadora de Políticas Públicas no campo do Turismo, sendo particularmente influente em países menos desenvolvidos e nos sistema das Nações Unidas de organizações da qual é membro." (OMT apud HALL, 2001, pg. 152).

Em termos de Política, as atividades da OMT têm sido bastante positivas. O ex-secretário-geral da Organização, Antonio Enriquez Savignac, participou da Rio-92, o que foi útil para incluir o Turismo na agenda 21 como uma das únicas indústrias capazes de propiciar incentivo econômico para a 
preservação do meio ambiente pode-se então observar que o Turismo é uma atividade que a cada dia cresce bastante, e vem conquistando seu espaço, principalmente por ser uma atividade que mais se preserva a natureza e os bens públicos (PINTO apud HALL, 2007).

Como exemplo de Política Pública significativa, no caso da EMBRATUR, pode-se exemplificar a representação da EMBRATUR no exterior, hoje, Escritórios Brasileiros de Turismo, pois são de fundamental importância para aumentar o número de turistas no Brasil, fazendo com que aumente o desenvolvimento do País, tanto econômico, como sócio-cultural.

Após estas definições é possível afirmar que os termos políticos e planejamento estão ligados. Este planejamento proporciona que as metas sejam alcançadas nas Políticas Públicas de forma mais eficiente. Pode-se até fazer uma comparação entre o processo de planejamento de Políticas Públicas com o Marketing, ambos trabalham com funções similares, que é atender a necessidade da sociedade, do mercado. As Políticas Públicas tem a função de incluir os cidadãos dentro de uma sociedade, e o Marketing procura sempre aperfeiçoar as atividades atendendo o mercado na melhoria de seus produtos e serviços turísticos dentro da sociedade.

\section{3 - MARKETING NA ATIVIDADE TURÍSTICA}

O Marketing Turístico surgiu da necessidade de melhor atender aos diversos anseios e de se atingir o patamar mais elevado da satisfação total do cliente, com o serviço oferecido. Podemos verificar que este caracteriza o conjunto de atividades que facilitam a realização de trocas entre os diversos agentes que atuam, direta ou indiretamente, no mercado de produtos turísticos. Também, tornou-se essencial ao papel de aguçar o mercado turístico em dimensões crescentes quanto às condições globalmente competitivas do trade, orientando para a definição de metas e escolhas estratégicas, que possam vir a atender adequadamente às características das organizações e do público-alvo. 
O marketing de Turismo pode ser definido como um processo administrativo através do quais as empresas e outras organizações de Turismo identifica seus clientes (turistas), reais e potenciais, e com eles se comunicam para conhecerem e influenciarem suas necessidades, desejos e motivações; nos planos local, regional, nacional e internacional em que atuam, com o objetivo de formular e adaptar seus produtos para alcançar a satisfação ótima da demanda (BENI, 2001, p. 207).

Nas localidades, as estratégias de marketing turístico devem estar em acordo com as constantes mudanças tecnológicas, econômicas e sociais que ocorrem no mercado, para que à proporção em que as condições e clientes mudem, os produtos sejam aperfeiçoados e novos possam ser criados.

\begin{abstract}
Uma abordagem de marketing para o desenvolvimento de localidades é a resposta assoladora que os locais precisam para competir com êxito em nossa economia. Eles precisam fabricar produtos e serviços dos quais os clientes atuais ou futuros necessitam ou desejam; devem vendê-los interna e externamente, nacional e internacionalmente. O marketing de localidade é uma atividade contínua que precisa de ajustes para atender às condições de uma economia mutante e novas oportunidades. (KOTLER; et al., 1994, p. 366).
\end{abstract}

Acerenza (1991, p. 40) complementa esta idéia ao dizer que se uma localidade deseja introduzir seu destino no mercado "deverá efetuar um duplo esforço promocional, uma vez que, além de dá-lo a conhecer ao consumidor, deverá diferenciá-lo dos produtos oferecidos por outros destinos competidores".

No entanto, é necessário direcionar esforços de promoção nos mercados específicos e prioritários, para que estas ações não sejam executadas sem um propósito. Tal afirmação fica mais clara na seguinte citação de Acerenza: 
Identificados os mercados, tanto naturais como potenciais, deve-se definir a política a seguir em relação aos mesmos, para efeito de concentrar os esforços promocionais naqueles considerados mais importantes e evitar-se, assim, a dispersão de esforços que significaria o desenvolvimento de ações de forma indiscriminada (...) (ACERENZA, 1991, p. 54).

Entenda-se também, por essa expressão, o conjunto de atividades que facilitam a venda, divulgação e melhor desenvolvimento do serviço turístico, englobando desde as pesquisas de demanda, mercado consumidor, até a publicidade e propaganda do produto então formatado.

A definição adotada por Vaz (1999, p. 18) diz que marketing turístico "é um conjunto de atividades que facilitam a realização de trocas entre os diversos agentes que atuam, direta e indiretamente, no mercado de produtos turísticos". Este conceito mostra a amplitude da atividade de marketing, considerando potencialmente todo o ecossistema do mercado turístico.

O marketing turístico tem como principal função conquistar e manter clientes. Segundo Trigueiro (1999, p.61), pesquisas comprovam que um turista satisfeito fala a três pessoas, enquanto um turista insatisfeito fala a onze. 96\% dos turistas insatisfeitos nunca relatam suas queixas e 34\% não volta ao destino turístico, preferindo outro. De acordo com este autor o que mais irrita os turistas é ver que os responsáveis por eles não se incomodam nem dão sinal de que vão resolver seus problemas.

Vale destacar que na hora de atrair turistas, o ponto importante é a seleção de mídia, na qual deverão ser veiculadas as campanhas institucionais e promocionais do local ou empreendimento turístico.

Mudanças de preferências e tendências são as principais ameaças do setor, que se transforma com a mesma velocidade nas quais as informações chegam aos mercados consumidores. Esse desafio pode ser sanado com monitorações constantes, através de pesquisas, evitando-se assim graves problemas mercadológicos. 


\section{3 - METODOLOGIA}

Nesta seção, são apresentados os procedimentos metodológicos adotados pela presente pesquisa, cuja característica principal é o seu caráter exploratório, descrito e documental.

A natureza exploratória é decorrente de duas razões: A primeira, por não existir nenhum trabalho que enfoque a agência federal de desenvolvimento do Turismo. A segunda, pela escassez de material impresso sobre o Instituto devido à perda de documentos decorrente da inundação do subsolo da sede da empresa no Rio de Janeiro, ocorrida em fevereiro de 1988, e a sua transferência para Brasília em 1992.

Vale destacar que devido a este fato existiu uma grande dificuldade em resgatar a memória do Instituto, que ficou perdida no tempo. A forma encontrada para obtenção das informações, foi principalmente por meio da memória vivenciada por diversos servidores (aposentados, ativos e exfuncionários), ex-dirigentes e lideranças de entidades de classe do setor, sujeitos desta pesquisa.

Do ponto de vista metodológico a pesquisa pode ser também considerada descritiva, por expor o fenômeno estudo à descrição das suas características. (BARBETTA, 2001, p.69). Vale destacar que, para o desenvolvimento do presente estudo foi utilizada tanto a pesquisa de campo, quanto a pesquisa documental e bibliográfica. Foram coletadas informações por meio de questionário junto aos sujeitos da pesquisa. A utilização deste conjunto de procedimentos deveu-se ao fato do presente estudo não dispor de informações sistematizadas para iniciar um questionamento.

A seguir, são apresentadas as duas etapas para condução da pesquisa. 


\section{1 - PRIMEIRA ETAPA DA PESQUISA}

Nesta fase foi realizada uma busca de dados e informações sobre o tema, através de livros e buscas na Internet, conforme descrito anteriormente. Vale salientar que para isto foi solicitada, junto a Administração da EMBRATUR, autorização para a busca nos arquivos. Também foram preparados 4 (quatro) questionários, que foram aplicados junto aos expresidentes, representantes de entidades, jornalistas e servidores e exservidores da EMBRATUR.

Segundo Barbetta (2001, p. 33), é fundamental a realização de préteste, antes de aplicar o questionário. Visando detectar algumas falhas na realização dos questionários, foi realizado um pré-teste, que também contribuiu para que se pudesse estimar o seu tempo de aplicação. Neste estudo, o préteste foi utilizado quando da realização da festa dos 40 anos da EMBRATUR, no dia 22 de novembro de 2006, onde houve contato com os ex-presidentes, alguns jornalistas e empresários do setor.

A partir desse momento, iniciou-se a estruturação dos questionários, que foram aplicados na segunda semana de janeiro de 2007. Devido ao período de férias do início do ano, obteve-se algum retorno somente no final de março de 2007.

Segundo Barbetta (2001, p. 27), uma variável observada (ou medida) em um elemento da população deve gerar apenas um resultado. Ainda segundo o referido autor, essas variáveis surgem quanto perguntamos o que vamos medir nos elementos da população.

As entrevistas foram realizadas por meio de questionários, a respeito do tema da pesquisa. Por esta razão, foi utilizado neste estudo um roteiro estruturado, que orienta a coleta dos dados, conforme pode ser visto no Apêndice I. 


\section{2 - SEGUNDA ETAPA DA PESQUISA}

Nesta etapa procedeu-se à busca aos arquivos da EMBRATUR e envio de questionários aos servidores ativos, aposentados, ex-funcionários, exdirigentes, representantes das entidades de classe do setor e jornalistas especializados em turismo.

Foram realizadas 15 (quinze) entrevistas de acordo com as seguintes categorias:

- 4 (quatro) com ex-presidentes: Sr. Miguel Colasuanno, Sr. João Dória Jr., Sr. Flávio Coelho, Sr. Caio Luiz de Carvalho;

- 4 (quatro) com presidentes de entidades de classe do setor: (ABIH - Associação Brasileira da Indústria de Hotéis, ABRACEFF - Associação Brasileira dos Centros de Convenções e Feiras, ABEOC - Associação Brasileira das Empresas Organizadoras de Congressos e Convenções, FENACTUR - Federal Nacional de Turismo;

- 3 (três) com jornalistas de Turismo (Jornal do Turismo, Folha do Turismo e Brasilturis) e

- 6 (seis) com servidores da EMBRATUR, sendo 2 ativos e 4 exfuncionários.

Visando a obtenção de informações foram encaminhados questionários para 20 (vinte) pessoas, porém apenas 15 retornaram. A taxa de retorno de $75 \%$ foi considerada boa. Vale destacar, que os entrevistados são os principais fornecedores dos dados/informações sobre o tema desta pesquisa "Memória do Turismo: Trajetória Histórica da EMBRATUR no período de 1966 a 2006, aqui apresentada". 


\subsection{1 - Instrumento de Coleta de Dados}

O instrumento da coleta constituiu-se de 4 (quatro) questionários, cada um dirigido a um segmento do grupo de sujeitos da pesquisa (vide Apêndice 1). Eles foram compostos de perguntas abertas e enviados via e-mail, no período de 05 de janeiro a 20 de março de 2007.

O primeiro questionário foi composto por 6 (seis) perguntas enumeradas e dirigidas aos ex-presidentes da EMBRATUR. O segundo e o terceiro foram dirigidos aos empresários e jornalistas do trade turístico, contendo 2 (duas) perguntas. O quarto questionário foi dirigido aos servidores (ativos e aposentados, além de ex-servidores) que trabalharam há mais de 20 anos na empresa.

A estrutura do primeiro questionário contava de 6 (seis) partes:

- a primeira teve a finalidade de identificar as principais atividades que foram desenvolvidas no intervalo dos primeiros 10 anos;

- a segunda, versou sobre os desafios e obstáculos enfrentados em cada gestão;

- a terceira, enfocou as estruturas organizacionais do período;

- a quarta, abordava o panorama do Turismo brasileiro à época; a quinta estava direcionada à importância do crescimento da profissionalização da atividade turística e, por fim, a sexta, identificou a visão estratégica de cada presidente referente à sua gestão.

O segundo, terceiro e quarto questionários foram divididos em 2 (duas) partes:

- o primeiro teve a finalidade de identificar o papel da EMBRATUR no desenvolvimento do Turismo brasileiro; 
- o segundo buscou conhecer as percepções dos representantes das entidades turísticas, dos jornalistas de Turismo e dos servidores (ativos e aposentados, além de ex-servidores que trabalharam mais de 20 anos na empresa), quanto à EMBRATUR.

\subsection{2 - Coleta de Dados}

As respostas às perguntas formuladas tiveram por objetivo descrever 0 conhecimento e a opinião dos entrevistados, com a intenção de deixar registrado todo o trabalho em prol do Turismo no país, que foi desenvolvido para a empresa durante seus 40 anos. 


\section{4 - ORIGEM DA EMBRATUR}

Criada pelo Decreto-Lei $n^{\circ}$. 55, de 18 de novembro de 1966, no Rio de Janeiro, a Empresa Brasileira de Turismo, a EMBRATUR, foi um marco na história da Administração Pública no Brasil, pois foi a primeira empresa pública do país. O mesmo Decreto definiu a Política Nacional de Turismo, criou o Conselho Nacional de Turismo, instituiu os incentivos fiscais e extinguiu a Divisão de Turismo e Certames, do Ministério da Indústria e do Comércio (encarregada de todos os assuntos relacionados ao Turismo até então), e que já não atendia mais às necessidades de expansão do setor. A Empresa foi estruturada contendo três áreas de atuação: Presidência, Diretoria de Assuntos Turísticos e Diretoria de Assuntos Econômicos.

À época, em 1966, o então Ministro Paulo Egydio Martins, apresentou a primeira exposição de motivos para a criação do órgão, bem como o projeto de lei, ao então Presidente do Brasil, Sr. Humberto de Alencar Castelo Branco.

Na exposição de motivos apresentados, o Turismo foi mostrado como fonte de geração de divisas e empregos, o que seria de grande contribuição para a economia do País. No entanto, havia a necessidade de ampliação do parque hoteleiro, assim como uma fiscalização nas atividades das agências de viagens.

Todavia, segundo o Sr. João dos Santos Filho (INTERNET, 2005), a criação da EMBRATUR deu-se dois anos após o golpe militar de 1964, que destruiu a liberdade democrática do povo brasileiro. Por esse contexto, ele fala sobre a criação da EMBRATUR:

Foi no interior dessa conjuntura que surgiu a EMBRATUR. Portanto, sua função está além da busca de um ordenamento legal para a formulação de uma política nacional para o Turismo. Na verdade, os militares, nesse momento, entendiam ser a EMBRATUR o instrumento ideal para combater a idéia de ditadura assassina que os setores da sociedade nacional e internacional denunciavam. 
Vale ressaltar que, foi a partir dessa data, que surgiu a necessidade de se "vender" a imagem do Brasil como um lugar com praias, carnaval e mulheres bonitas. Com o passar do tempo, o governo teve que reverter essa imagem, que foi muito prejudicial para o nosso país e muito contribuiu para o tão falado e combatido "Turismo Sexual Infanto-Juvenil".

De acordo com o Dr. Joandre Ferraz (Diretor da Empresa - 1987), a existência da EMBRATUR regeu a organização e sistematização de todos os empresários envolvidos na atividade; das agências de viagens às transportadoras.

O setor do Turismo vem se desenvolvendo de forma acelerada. A EMBRATUR tem contribuído com grande participação nesse aspecto, atuando para organizar, da melhor maneira possível, a continuidade da atividade turística.

A criação da EMBRATUR foi para dar o reconhecimento da importância econômica do Turismo e da necessidade de se contar com uma agência responsável pelo fomento e normalização (EMBRATUR, 1990).

Segundo depoimento do Procurador aposentado, Dr. Reinaldo Nunes, matrícula no. 4: "A evolução da atividade turística no Brasil, nessas últimas duas décadas (1966/1986), está interligada à história da EMBRATUR. Tanto suas realização quanto suas limitações, refletiram-se de forma significativa nas atividades do setor. Por isso, ao se comentar os acontecimentos que marcaram as distintas gestões da Empresa, estar-se-á, simultaneamente, expondo os destaques da história recente do Turismo brasileiro".

A criação da EMBRATUR está relacionada diretamente ao reconhecimento da importância do Turismo, enquanto fonte de geração de divisas; à intenção de ampliar e modernizar o parque hoteleiro e à necessidade de disciplinar as atividades das agências de viagens, responsáveis por graves prejuízos infringidos ao público, por ocasião da Copa do Mundo, de 1966. Representa também um marco na história da administração pública brasileira por ter sido a primeira empresa pública no país. 
O conceito de empresa pública na época só existia nas estruturas italiana e alemã, nos outros países eram autarquias. Coube-Ihe, portanto, o ônus do pioneirismo na criação de uma identidade institucional, constituindo, ao mesmo tempo, um "know-how" próprio, voltado à elaboração, implantação e avaliação de programas e projetos turísticos, contando com a menor equipe técnico-administrativa dentre as empresas governamentais federais.

Esse esforço foi realizado vencendo dificuldades advindas, muitas vezes, do desconhecimento das autoridades, de diversos níveis e esferas, no que tange à função econômica e social do Turismo.

Com a evolução do transporte aéreo, os destinos tornaram-se mais acessíveis e o Brasil viu-se numa situação favorável, onde precisava aumentar a demanda. Daí a necessidade de se criar a EMBRATUR, que à época teve como enfoque principal o incentivo financeiro e a isenção e diminuição de impostos nos empreendimentos hoteleiros, pois se observou que existia uma carência de hotéis de classe no país.

De forma imediata, a criação da EMBRATUR deveu-se à iniciativa do Ministro da Indústria e do Comércio, Sr. Paulo Egydio Martins, que em junho de 1966 apresentou a 1 ${ }^{\mathrm{a}}$ Exposição de Motivos neste sentido, bem como o Projeto de Lei, ao então Presidente da República Humberto de Alencar Castello Branco.

$\mathrm{Na}$ Exposição de Motivos é indicada a contribuição para a economia nacional que o Turismo poderia trazer, ressaltando-se que a Divisão de Turismo e Certames, órgão integrante do Ministério da Indústria e do Comércio, então encarregado dos assuntos de Turismo, não poderia, por sua estrutura, atender às necessidades de expansão dessa rendosa indústria.

Ao propor a criação de empresa pública para condução dos assuntos do Turismo, foram indicados como fonte de recursos para sua implantação e funcionamento, além daqueles da União, os originados da venda de selos postais comemorativos ou de propaganda, do Brasil, e os do Fundo Turístico Nacional. Este Fundo seria constituído, entre outros, pela Taxa de Turismo, que incidiria sobre as passagens de viagens do Brasil ao exterior, à razão de 
$2 \%$ sobre o valor da passagem; sobre o montante dos prêmios pagos nos hipódromos do país, à razão de $5 \%$ e sobre os bilhetes de loteria, à razão de $2 \%$ do respectivo preço.

$\mathrm{Na}$ mesma Exposição, é sugerido que a construção, ampliação e reforma de hotéis, obras e serviços específicos de finalidade turística, constituindo atividades econômicas de interesse nacional (desde que aprovadas pela EMBRATUR), fossem equiparadas às instalações e ampliações das indústrias básicas e, assim, incluídas no item IV, do Art. 25, da Lei 2973, de 26 de novembro de 1956.

Em 15 de novembro de 1966 foi encaminhada, pelo Ministério da Indústria e do Comércio, nova Exposição de Motivos sugerindo a criação da EMBRATUR. Este trabalho resultou de re-estudo conjunto deste Ministério, do Ministério da Fazenda do então Ministério do Planejamento e Coordenação Geral.

Na Exposição são ratificados os dados sobre a importância econômica do Turismo e sugerida a criação do Conselho Nacional de Turismo. No tocante aos recursos financeiros da nova empresa, foi informado que eles viriam, principalmente, do orçamento público.

No ato de criação, foi-Ihe destinado um capital de CR $\$ 50.000 .000,00$ (mediante dotações orçamentárias ou créditos especiais a serem integralizados até o exercício de 1971), em parcelas anuais de CR $\$ 10.000 .000,00$ (valores da época). Além desse capital, foram previstos, ainda, créditos especiais e suplementares, contribuições públicas ou privadas, juros e amortizações dos financiamentos que a Empresa realizasse e a receita do Selo do Turismo, constituída da venda de séries especiais de selos, editados pelo então Departamento de Correios e Telégrafos, com um adicional de não menos de $20 \%$ e não mais de $35 \%$ destinados a integrar os recursos da EMBRATUR.

A criação formal da EMBRATUR não implicou na sua imediata instalação. A posse do Presidente Arthur da Costa e Silva e de sua equipe da área econômica redundou no reexame dos recursos a serem alocados à 
EMBRATUR. Com os recursos da instalação, a EMBRATUR subsistiu nos primeiros anos de existência.

Em parte como decorrência do preceito legal da existência de estímulos governamentais locais para concessões dos incentivos fiscais, o surgimento da EMBRATUR ensejou a criação, em todos os Estados e Territórios, de organismos voltados ao desenvolvimento do Turismo.

CNTUr, EMBRATUR e esses organismos, juntamente com a iniciativa privada, constituíram o Sistema Nacional de Turismo, para cuja estruturação e fomento a ação da EMBRATUR foi decisiva.

Segundo dados do artigo Mundo Econômico - EMBRATUR (1974), Sr. Paulo Manoel Protássio, ex-presidente da EMBRATUR, (1973) declarou que: "na década de 50, e metade da de 60, o Turismo, não representava um papel de interesse relevante na economia nacional, em razão da frágil conjuntura econômico-financeira do país, que não permitia a criação de uma infraestrutura turística, pois eram outras as metas prioritárias, nem a participação da população na dinâmica do fenômeno turístico. Com o impulso econômico, que ocorreu em 1964, o Turismo atraiu a atenção do Governo Federal, principalmente em função de ser uma mola propulsora de desenvolvimento, bem como por seu extraordinário efeito multiplicador".

Tornava-se urgente resolver o problema de implantação de uma indústria turística sólida, pois havia sido verificado que o sistema de acomodações era deficitário tanto qualitativa e quantitativamente; que a rede de transporte era precária e as comunicações difíceis; que setores básicos como a energia, água e esgoto eram incipientes; que o pessoal necessário à gestão de empresas turísticas não era qualificado e que inexistia um órgão federal que coordenasse a política nacional de Turismo".

Do ponto de vista do Dr. Gerson Antonio Fonseca, Procurador Aposentado da EMBRATUR, funcionário $\mathrm{n}^{\circ}$. 1, a Empresa Brasileira de Turismo - EMBRATUR, nasceu de um anteprojeto, elaborado todo ele inicialmente pelos técnicos existentes na extinta Divisão de Turismo e Certames do Ministério da Indústria e do Comércio - MIC, sob a orientação da 
Sra. Lucy Bloch, que durante mais ou menos 16 anos dirigiu esta Divisão, tendo sido encaminhado, dentro da ordem hierárquica então existente, ao Senhor Secretário do Comércio, Dr. Joaquim Xavier da Silveira, que acrescentou ao trabalho a parte referente à constituição do Conselho Nacional do Turismo e à concessão de incentivos fiscais, e envidou todos os seus esforços no sentido de que fosse finalmente aprovado o Decreto-lei $n^{\circ} .55$, de 18 de novembro de 1966, que criava o Conselho Nacional de Turismo e a Empresa Brasileira de Turismo - EMBRATUR e extinguia a Divisão de Turismo e Certames do MIC, passando dessa forma a ser o $1^{\circ}$ Presidente da Empresa recém-criada.

Encerrado estava, também, o trabalho executado pela Divisão de Turismo e Certames do MIC - Ministério da Indústria e do Comércio, cujas atribuições, acervo e pessoal foram divididos entre a Empresa e a Divisão de Exposições e Feiras que permanecia no Ministério da Indústria e do Comércio.

Na opinião do Dr. Gérson, a implantação do Turismo no Brasil, como todas as demais atividades existentes no país, iniciou-se através de esforços isolados da iniciativa privada e de órgãos regionais que objetivaram, na época, mais ao estabelecimento de posições políticas do que propriamente à sistematização da "Indústria sem chaminés".

O primeiro passo dado pelo Governo no sentido de tentar estabelecer normas regulares do Turismo no país ocorreu em 1934, com a criação da Comissão Permanente de Exposições e Feiras, criada pelo Decreto nº. 24.163, de 24 de abril de 1934.

Atendendo às constantes solicitações do empresariado, procede-se através do Decreto-lei no. 2.440/40, de 23 de julho de 1940, a regulamentação das atividades das empresas e agências de viagens e Turismo, passando tal atribuição a ser exercida pelo Departamento de Empresa e Propaganda, e posteriormente pela Superintendência de Reforma Agrária (SUPRA), sendo da competência do Ministério do Trabalho, Indústria e Comércio o registro e fiscalização das agências de navegação, e de passagens marítimas, fluviais e aéreas. 
Mesmo contando com a falta de recursos e de pessoal devidamente treinado para o desempenho daquelas atividades, os mencionados órgãos, conseguiram, dar início à estruturação administrativa e ao estabelecimento de contatos, com órgãos nacionais e internacionais, possibilitando dessa forma, 0 surgimento do embrião do Turismo no país.

Todavia, decorreu uma década antes que a Comissão Brasileira de Turismo - COMBRATUR, subordinada à Presidência da República, fosse criada pelo Decreto 44.863, de 21 de novembro de 1958, com o objetivo de coordenar as atividades destinadas ao desenvolvimento do Turismo interno e ao afluxo do estrangeiro; estudar e supervisionar as medidas relacionadas com a movimentação de turistas, com a simplificação, padronização das exigências e dos métodos de informação e registro, e inspeção relativa aos viajantes e a seus bens, recursos pessoais, meios de transportes e hospedagem; destacando-se dentre as atividades executadas pelo órgão a participação em vários congressos no exterior com o envio de representantes; a inscrição do Brasil na UIOOT - União Internacional dos Organismos de Turismo, através do Ministério das Relações Exteriores, e a Elaboração do $1^{\circ}$ Mapa Turístico do Brasil, baseado na Divisão Turística do Território Nacional, de acordo com o disposto no Decreto $\mathrm{n}^{\circ}$. 51.130/61.

É importante observar que, pela própria composição e estrutura, a COMBRATUR não poderia executar plenamente suas atividades, devido às dificuldades naturais de convocação e presença de todos os seus membros integrantes.

Torna-se oportuno ressaltar que, em 1953, o Conselho de Turismo da Confederação Nacional do Comércio, apoiado pelo então Deputado Nelson Carneiro, iniciou um movimento para a criação de um órgão de Turismo que orientasse a política turística nacional. O mesmo fez chegar ao Senado o projeto de lei $n^{\circ}$. 181/62, que iniciara sua trajetória na Câmara sob o no. 3.714B em 1953, criando o IBRATUR - Instituto Brasileiro de Turismo.

Sensibilizado pelas constantes investidas dos empresários e do legislativo e, ainda no sentido de dar uma solução imediata ao problema, criou- 
se através do Decreto-lei 534, de 23 de janeiro de 1962, a Divisão de Turismo e Certames do Ministério da Indústria e do Comércio, órgão pertencente ao Departamento Nacional do Comércio da Secretaria do Comércio do MIC, com a incumbência de exercer os seguintes encargos: promover, organizar e fiscalizar exposições, feiras e certames no território nacional e no exterior; além de processar os pedidos de autorização ou de concessão para funcionamento de exposições, feiras e certames congêneres de indústria e comércio, exercendo as demais atribuições da extinta Comissão Permanente de Exposições e Feiras, sendo nomeada para sua direção a Sra. Lucy Bloch.

A mencionada Divisão, encravada no sistema hierárquico da administração pública federal, observando e seguindo todas as normas da burocracia pública, com deficiência de material e pessoal, conseguiu superar uma série de entraves e realizar, em 5 (cinco) anos de existência, um trabalho em cujas bases se assentou a EMBRATUR - Empresa Brasileira de Turismo.

Estudiosa dos problemas turísticos e havendo tido contato com dirigentes dos principais órgãos de Turismo internacionais, antes de aceitar o cargo de Diretora da Divisão de Turismo e Certames do MIC, a Sra. Lucy Bloch, trouxe para o serviço público a mentalidade da empresa privada e imprimiu uma dinâmica de grande empresa à pequena Divisão então recém criada.

No trabalho realizado pela extinta Divisão, que serviu de base para as tarefas executadas pela EMBRATUR à época, pôde-se destacar algumas atividades, segundo depoimento do Dr. Gérson Fonseca, procurador aposentado do Instituto:

a) Elaboração do Calendário Nacional de Exposições, cuja divulgação era feita no Brasil através das Delegacias Regionais do MIC, de órgãos de classe da Indústria e do Comércio, e no exterior, através da Divisão de Propaganda e Expansão Comercial do M.R. E Ministério das Relações Exteriores e aos órgãos de Turismo internacionais, e de Exposições e Feiras, com Bureau Internacional des Expositions em Paris, França; 
b) Elaboração do $1^{\circ}$ Guia de Turismo Nacional;

c) Elaboração do $1^{\circ}$ Guia Hoteleiro Nacional;

d) Elaboração de normas para o registro e fiscalização das agências de viagens (Decreto $n^{\circ}$. 59.193/63), e iniciação do cadastramento e fiscalização das agências existentes, bem como elaboração de uma relação de agências registradas, sendo sua divulgação feita aos órgãos interessados e às Delegacias Regionais do MIC;

e) Organização da participação turística do Brasil em vários certames no exterior, através do MRE e mesmo através de delegados próprios, como no caso da Feira de Bogotá (Colômbia), Feira de Santarém (Portugal), Feira Del Campo (Madrid, Espanha) e várias outras com a montagem de "stand" de divulgação turística;

f) Participação no I Congresso Hispano-Luso-Filipino de Turismo, realizado em Madrid, onde a delegação do Brasil, presidida pela Sra. Diretora da Divisão de Turismo, teve destacada atuação, indicando ainda observadores do MRE - Ministério das Relações Exteriores para vários outros eventos de interesse turístico realizados no exterior;

g) Elaboração dos primeiros folhetos de divulgação turística do Brasil: "Praias do Brasil", "Brasília", "Brasil - Arte Sacra", "Carnaval do Rio"; (Anexo II)

h) Iniciação de gestões com grupos estrangeiros, para a construção de hotéis e instalações de empreendimentos turísticos no país.

Finalmente, a Diretoria da Divisão de Turismo e Certames foi incumbida pelo Ministro da Indústria e do Comércio à época, Dr. Paulo Egydio Martins, de elaborar um projeto para a criação de um órgão de Turismo nacional.

Surgiu inicialmente à idéia do IBRATEC - Instituto Brasileiro de Turismo, Exposições e Certames, que deveria substituir o projeto então 
existente do IBRATUR - Instituto Brasileiro de Turismo, que contava com o apoio inconteste da iniciativa privada ligada ao campo do Turismo. Todavia, como a nova política governamental era literalmente contrária à constituição de mais institutos, adotou-se a solução criada pelo Decreto-lei n'. 200 , ou seja, de uma Empresa Pública.

"Eis que o Brasil dava o seu grande passo para ingressar no rol dos países desenvolvidos, colocando o Turismo, até então tratado em tom jocoso pelas autoridades em geral, agora no seu devido lugar, como integrante das indústrias de base do País" (FONSECA, 1988).

Iniciava-se assim, em 1966, com a criação da EMBRATUR, a entrada do Brasil na era do Turismo Técnico (FONSECA, 1988).

A Estrutura administrativa da EMBRATUR, em 1967/1971 era composta pelos cargos de presidência e 3 (três) diretorias. Seu presidente na época era o Sr. Joaquim Manoel Xavier da Silveira.

Vale ressaltar que, na época em que teve o seu maior crescimento em recursos humanos, a empresa chegou a ter 450 funcionários, menos do que outros órgãos similares.

Contudo, no início a empresa não oferecia Plano de Cargos e Salários. Existia um salário para cada atividade, desestimulando alguns funcionários que acabavam acumulando funções. Com a implementação do Plano de Cargos e Salários esse quadro mudou, permitindo aos funcionários ascensão profissional. Quatro servidores do quadro da casa alcançaram cargos de diretoria, o que incentivou e melhorou a qualidade do ambiente de trabalho.

O quadro inicial efetivo da EMBRATUR, de 450 servidores, foi sendo reduzido até chegar aos atuais 76 servidores. Porém, desses 76 servidores, somente 47 estão em atividade na Instituição. Essa situação é resultado de uma reestruturação organizacional, de gestões eminentemente políticas, sob intervenção, de mandos "políticos" na ocupação de cargos estratégicos e devidamente loteados por interesses partidários. 


\section{1 - OS DEZ PRIMEIROS ANOS DA EMBRATUR (1966 - 1976)}

De acordo com o depoimento do Dr. Gérson Fonseca, procurador aposentado, nos seus primeiros dez (10) anos, a EMBRATUR, praticamente cuidou apenas da elaboração e sistematização das normas necessárias à aplicação de incentivos e ao adequado registro e fiscalização das agências de viagens. Nesses primeiros 10 (dez) anos, foram aprovados projetos de construção de hotéis de nível internacional no País, bem como do maior centro internacional de feiras e convenções nacional, o Anhembi, em São Paulo.

Em 1971, por meio da promulgação de decreto-lei que, entre outras providências, criou o FUNGETUR - Fundo Geral de Turismo, criado para atender uma demanda diversificada de recursos e, também, facilitar o acesso de pequenos e médios empresários aos recursos oficiais (EMBRATUR, 1990).

Em 1973, foi instituído pela primeira vez, o Ano Nacional do Turismo, e lançado o programa "Conheça o Brasil" para intensificar o Turismo interno.

Em 1975, foi autorizado o funcionamento de lojas francas (free shops) para venda de mercadoria nacional e estrangeira na zona primária dos portos ou aeroportos. Em 1976 o DAC - Departamento de Aviação Civil autoriza a realização de vôos de Turismo doméstico com desconto e a EMBRATUR fixa os processos de pedido de tramitação dos mesmos, cujo objetivo era intensificar o Turismo interno. Ainda em 1976, a EMBRATUR institui estímulos fiscais ao Turismo estrangeiro no país e, em 1977, regulamenta as excursões no programa "Voe de Turismo Doméstico, para excursões em grupo, com descontos, e dado o primeiro esforço para ordenação do uso do solo e dos recursos turísticos". (FONSECA, 1988).

No período de 1975 a 1979, a EMBRATUR passou a ter nova estrutura, com a criação das diretorias de Planejamento, Investimentos e Operações. Em 1977 tornou-se obrigatório o registro na EMBRATUR das empresas exploradora de atividades turísticas, como meios de hospedagens, agências de viagens e as transportadoras turísticas, entre outros. 
Ainda segundo Dr. Paulo Manoel Protássio, "o desenvolvimento do Turismo no Brasil, década 60 e 70, pode ser dividido em três fases: 1) a fase anterior a 1966, na qual a coordenação das atividades era feita de maneira empírica pela Divisão de Turismo e Certames do Ministério da Indústria e Comércio; 2) a fase de 1966 a 1971, na qual foram delineadas as bases de uma política nacional de Turismo; 3) fase posterior a 1971, na qual se procurou implantar definitivamente o sistema nacional de Turismo".

Já para o Dr. Gérson Fonseca, (Procurador aposentado da EMBRATUR), "equiparada à instalação de indústrias básicas, através da discriminação constante no item IV do artigo $n^{\circ}$. 25, da Lei 2.973 de 26 de novembro de 1956, a indústria do Turismo dava, em 18 de novembro de 1966, o primeiro passo para situar-se entre as demais atividades industriais existentes na época, com o advento do decreto-lei nº 55/66, que tem como objetivo principal a definição da política nacional do Turismo e a criação do Conselho Nacional do Turismo e a Empresa Brasileira de Turismo EMBRATUR".

À primeira Diretoria da Empresa recém-criada, presidida pelo Dr. Joaquim Xavier da Silveira, coube a árdua tarefa de implantar a Empresa e também de estabelecer a mecânica para a aplicação da política de incentivos fixada no Capítulo V, artigos 23 a 28 do referido diploma legal.

Em 10 de março de 1967, foi aprovado o estatuto da EMBRATUR, cujo objetivo era a estruturação administrativa da Empresa. Após a aprovação, constituiu-se a Diretoria da Empresa com um Presidente, um Diretor para Assuntos Turísticos e outro para Assuntos Econômicos, ficando o Conselho Nacional de Turismo - CNTur, presidido pelo então Ministro da Indústria e Comércio e constituído de Delegados de órgãos federais e representantes da iniciativa privada e formular a Política Nacional de Turismo.

Durante os quatros anos de atividades no Setor, a Diretoria da Empresa executou algumas atividades, apesar da insuficiência de recursos econômicos, como: 
> Criação do Setor de Estatística;

> Criação do Serviço de Informação Turística nos Aeroportos Internacionais do país;

> Fixação de definição sobre Hotel de Turismo;

> Estabelecimento de normas administrativas, regulamentando o procedimento do contribuinte para efeito de recolhimento e aplicação dos recursos provenientes dos incentivos fiscais, de que tratam os artigos 25 e 26 do decreto-lei 55/66;

- Elaboração de um guia hoteleiro e um calendário turístico nacional;

Organização de um Centro de Informações e Documentação Turística;

Levantamento das zonas balneárias, estâncias climáticas e hidrominerais.

Vale ressaltar, que nas primeiras gestões, principalmente nas gestões dos Srs. Joaquim Xavier da Silveira, $1^{\circ}$ Presidente, Sr. Carlos Alberto de Andrade Pinto, $2^{\circ}$ Presidente e do Sr. Paulo Manoel Protássio, $3^{\circ}$ Presidente, o orçamento era insuficiente para investimentos e promoções, sendo restrito para o custeio (aluguel, pessoal, etc.).

Observa-se, dessa forma, que dentro deste primeiro estágio da aplicação da política nacional de Turismo, além das atividades já discriminadas, a EMBRATUR analisou e obteve a aprovação do CNTur para efeito da aplicação de incentivos na construção, ampliação e melhoramento de hotéis. Os recursos liberados atingiram o montante de CR\$ 67.504.274,58, criaram aproximadamente 4.000 unidades habitacionais e geraram quase 15.000 empregos, o que demonstra categoricamente o bom desempenho das Diretorias e seus esforços no sentido de criar e alicerçar a infra-estrutura do Turismo nacional. 
Naturalmente, a atividade hoteleira foi a grande beneficiada nesse início, por ser o setor mais carente de apoio, em virtude das grandes somas de recursos próprios que o empresário nacional teria de investir na área. No que tange às agências de viagens, a empresa exerceu atividade fiscalizadora permitindo, assim, o saneamento do mercado e exigindo melhor atendimento aos usuários.

Nesse período, podemos destacar dois fatos muito importantes que contribuíram para o desenvolvimento do Turismo: a inauguração dos aeroportos internacionais do Galeão no Rio de Janeiro (rebatizado, posteriormente de Tom Jobim), de Manaus e do Recife, além da instalação do primeiro hotel pertencente a uma cadeia internacional: São Paulo Hilton. Também nesse período é lançada a idéia dos "portões de entrada" em Manaus, Fortaleza, Recife, Belém e Salvador.

Percebe-se a necessidade de investir no Turismo brasileiro, pois turistas brasileiros levam para fora do país US\$24 milhões, enquanto os turistas estrangeiros deixam aqui US\$ 9 milhões.

Além da comemoração do $10^{\circ}$ aniversário da EMBRATUR, pela primeira vez, registra-se o decréscimo na saída de turistas brasileiros e aumento da entrada de turistas estrangeiros.

Barreto (1991) chama atenção para o fato de que em 1977, onze anos após a criação da EMBRATUR, publicou-se um documento contendo a Política Nacional do Turismo, onde constam as políticas de:

- Proteção ao patrimônio cultural;

- Divulgação e promoção de valores culturais;

- Incentivo ao Turismo interno (com construção de meios de hospedagem mais simples e redução de custos das viagens internas);

- Estímulo ao Turismo do exterior para o Brasil; 
- Promoção;

- Recursos humanos;

- Apoio à entrada de divisas;

- Apoio à hotelaria;

- Apoio às agências de viagens.

De acordo com a publicação EMBRATUR 40 anos (2006), os dados desse período referentes ao Turismo são os seguintes.

- 1.278.314 turistas estrangeiros, cerca de 500 mil de países da América do Sul, entraram no Brasil no período de 1963 a 1970.

- $\quad 141.421$ turistas estrangeiros visitaram o país em 1967

- 140 mil turistas estrangeiros chegaram ao Brasil em 1972

- 57 projetos de novos hotéis foram aprovados entre 1972 e 1973, totalizando cerca de 4.620 unidades (quartos para hospedagem), o que representa a criação de cerca de 20 mil empregos.

- 233 mil leitos em hotéis já estavam disponíveis em 1974. No mesmo período, a França oferecia 782 mil, a Espanha 836 mil e os Estados Unidos, cerca de 5 milhões de leitos.

- 450 mil turistas estrangeiros entraram no Brasil em 1976.

A Estrutura administrativa da EMBRATUR, em 1971/1975 (2a , $^{\mathrm{a}}$ e $4^{\mathrm{a}}$ Gestão), era composta pelos cargos de presidência e 3 (três) diretorias. A Empresa Brasileira de Turismo - EMBRATUR, à época, estava sediada na Praça Mauá, Prédio do INPI - Centro - Rio de Janeiro. Ocuparam a presidência, os Srs. Carlos Alberto de Andrade Pinto e Said Fahrat. 


\section{2 - OS VINTE ANOS DA EMBRATUR (1977 - 1987)}

Nos seus 20 anos, a EMBRATUR entrou para era da informatização, o que permitiu a agilização na obtenção de informações, a implantação e controle da ficha nacional de registro de hóspede e a elaboração do boletim de ocupação hoteleira; instrumentos essenciais para o acompanhamento e estudos dos fluxos turísticos.

Foi nessa época que o Turismo conseguiu o reconhecimento da importância econômica da atividade. Também, quando foram iniciadas pela primeira vez na história da EMBRATUR, a promoção e divulgação do país no exterior. Pois, como foi dito anteriormente, a Empresa só tinha orçamento para seu custeio. Vale ressaltar que neste período deu-se o início da participação do "trade" nacional, de forma sistemática, aos principais eventos comerciais no exterior.

Em 1979 começaram os pacotes de viagens para o Norte e Nordeste do Brasil e, em 1981, foi instituído, por meio de uma empresa aérea, o sistema de reservas por telefone. Também em 1981, o cálculo da receita turística foi, pela primeira vez, incluído na balança de pagamentos do país, o que permitiu que o Turismo aparecesse com sua real e significativa contribuição. Vale ressaltar, também, que nesta época a EMBRATUR iniciou a abertura de escritórios de representação no exterior.

No período de 1985 a 1986 foi elaborada a proposta da Política Nacional de Turismo, homologada pelo Conselho Nacional de Turismo CNTur, que traçou os objetivos e metas do Turismo, de acordo com as diretrizes do $1^{\circ}$ Plano Nacional de Desenvolvimento da Nova República.

Data desse período, o grande momento de uma agressiva política de marketing dirigida ao mercado nacional e internacional, por meio de campanhas nacionais e internacionais realizadas em parceria com a iniciativa privada, programas de Turismo social, de estímulo aos investimentos no setor, além da reviravolta nos hábitos e velocidade de consecução dos objetivos 
traçados pela estatal. A aproximação do setor turístico com a publicidade é uma das marcas do período, além de nova participação nos eventos internacionais, com novo stand e conceito operacional, além de trazer os grandes ícones nacionais com reconhecimento internacional (como Pelé, Tom Jobim, Milton Nascimento, etc.), para divulgar o país no exterior.

Nesta mesma época, também se iniciou um processo de reorganização da empresa para adaptá-la ao máximo de eficiência empresarial. Foram criados e lançados novos programas de Turismo e deu-se início à campanha para a profunda remodelação da atividade turística nacional. Foi dado um novo ritmo à atuação no setor de Turismo internacional. Também, iniciou-se o processo de consolidação da imagem do Brasil no exterior.

Segundo Boletim da EMBRATUR (1988), neste período, foi criada a FUNTUR - Fundação Nacional do Turismo para formular e ativar os programas promocionais internacionais, com uma representação na França, foi reaberto o escritório da EMBRATUR em Nova York, além de criadas várias campanhas como:

- Passaporte Brasil - o objetivo era eliminar definitivamente a baixa temporada do calendário turístico e fomentar o Turismo interno (ANEXO IV);

- Passaportezinho Brasil - programa de incentivo ao Turismo infantil (ANEXO IV);

- Turismo para deficientes físicos - programa voltado aos deficientes, que incluía reivindicações de melhoria de toda infra-estrutura urbana, especialmente a turística (ANEXO IV);

- Albergue da Juventude - o objetivo era regulamentar e implantar cerca de 40 albergues em todo o país, além de motivar a juventude brasileira a viajar pelo país (ANEXO IV);

- O Rio continua lindo - após ter sofrido reflexos imediatos com as imagens geradas pela imprensa do desastre ocasionado pelas 
fortes chuvas de verão desaquecendo o Turismo no Estado, o objetivo era reabilitar a imagem da Cidade Maravilhosa (ANEXO IV);

- Turismo Ecológico - a campanha não só tinha objetivos preservacionistas como também divulgava os roteiros ecológicos;

- Turismo Saúde - era sustentado pela busca do contato com a natureza e o culto do corpo;

- Turismo Cultural - surgido da necessidade didática de levar as crianças e adolescentes a conhecer esta riqueza que é a nossa cultura;

- Turismo Rodoviário - o objetivo era estimular as viagens de ônibus e oferecer novas alternativas de roteiros turísticos (ANEXO IV);

- Cama e Comida - devido a pico de demanda e uma saturação em várias localidades do país, durante grandes eventos, exigindo que fossem agregados aos serviços regulares de atendimento ao Turismo de meios de hospedagens não tradicionais, sendo os dois lados beneficiados (turistas e anfitriões);

- Turismo da Terceira Idade - o clube da Maior Idade objetivava o ingresso do idoso no mercado turístico, além da instalação de clubes voltados à terceira idade;

- "Descubra o Brasil", "Emoção tem um nome: Brasil", "Brazil: it's what life was intended to be", tendo Pelé como garoto-propaganda e Embaixador do Turismo Brasileiro;

- "Respeite o Turista" - o objetivo era conscientizar profissionais de Turismo e a população em geral da necessidade de se oferecer atenção e simpatia aos visitantes;

- Disque Turismo - pretendia oferecer o melhor sistema de informações ao turista sobre os destinos e formulação de roteiros. 
João Dória, ex-presidente da EMBRATUR (1987), dizia: "O passado faz parte da história. O julgamento também. É preferível olhar o presente e o futuro e compreender o desafio das transformações necessárias para a derradeira arrancada do Turismo nacional".

..."Caberá sempre ao Estado a ordenação do território, o controle da qualidade, a defesa do consumidor e o fomento à atividade. Mas o êxito econômico do setor turístico, será resultado da livre iniciativa, em regime de mercado. Só nesta simbiose poderemos encontrar os caminhos para dinamizar as mudanças, lembrando que nada se fará sem o talento e a força do trabalho. A eles a nossa homenagem". (DÓRIA, 1987)

Nessa época, se a balança de pagamento da conta Turismo no Brasil, fosse tomada como principal parâmetro para a avaliação da eficácia da Empresa Brasileira de Turismo (EMBRATUR), nos seus 20 anos de existência, a empresa poderia ser julgada como uma empresa experiente. A EMBRATUR aprendeu a conviver com a desconfortável posição de empresa sem receita própria e com carência de recursos.

Em meados da década de 80, porém, estas mesmas contas passaram a exibir um saldo apreciável, a ponto de situarem o Turismo como quinto produto da pauta de exportação brasileira, com uma receita próxima a US\$1,5 bilhão em 1985.

Com isso, ao mesmo tempo em que se mantinha empenhada na instituição do "dólar-Turismo" - capaz de tornar mais reais os números da receita do setor e de situar o Turismo como segundo produto da pauta elevando este segmento como terceiro produto. Em 1989, foi instituído o dólarTurismo, com o objetivo de oficializar o superávit da balança comercial com a indústria turística (BARRETO, 1991, p. 96).

No final de agosto de 1987, o presidente José Sarney assinou decreto transformando 1987 em "Ano Nacional do Turismo". Na última vez em que isso aconteceu, em 1973, o Turismo no Brasil cresceu numa média de $18 \%$ ao ano, 
três vezes mais que a taxa mundial. O número de turistas que visitou o Brasil pulou de 400 mil para mais de 1,7 milhões, em 1985. Com mais um "Ano Nacional do Turismo", a mobilização em torno do setor, concedeu ao Turismo brasileiro a dimensão que dele se esperava para aquele momento.

Para João Dória, "o Ano Nacional do Turismo foi uma oportunidade de marketing para a indústria do Turismo nacional apresentar suas propostas e alavancar seu desenvolvimento"

Em 1990, foi criado um plano para área do Turismo, denominado "Estratégia para o desenvolvimento do Turismo no Brasil". Para o governo, o ingresso do Brasil no primeiro mundo, principalmente no Turismo, dependia da adoção desse plano.

Há quinze anos, esse plano já tratava o Turismo como fator importante para o desenvolvimento do País.

A constatação, em nível internacional, da importância do Turismo na economia dos países que exercitam e igualmente nos benefícios dos seus produtos, incluindo o Brasil, estimula a que se ofereça como desafio nacional, uma estratégia para o seu desenvolvimento. (EMBRATUR, 1990).

Nota-se, nesse plano, uma menor preocupação com outros fatores relacionados ao Turismo, notando-se uma maior abordagem nos fatores econômicos e sociais.

Ao longo desse trabalho procura-se mostrar a total factibilidade da condução da atividade turística, como uma das mais consentidas formas de contribuição para a economia nacional, somando-se ao esforço de incrementar a captação de divisas no exterior e a possibilidade de promover a redistribuição da renda. (EMBRATUR, 1990). 
Por meio de um Decreto do Presidente Collor, 1991 a sede da empresa no Rio de Janeiro, foi transferida para Brasília. Na época a empresa possuía um quadro de aproximadamente 450 funcionários. Para os funcionários, essa foi a primeira queda da empresa, pois nem todos aceitaram a transferência e preferiram ser transferidos para outros órgãos. Com isso foi-se, também, a memória da EMBRATUR. O processo de transferência durou dois anos.

De acordo com o plano, segundo dados da Organização Mundial do Turismo (OMT), o Turismo é a indústria que gera maior número de empregos e os negócios gerados fazem dessa atividade a terceira em volume de recursos movimentados, o que seria ideal para um país em desenvolvimento como o Brasil.

Já no período de 1992 a 1993, os investimentos na captação de turistas estrangeiros, por meio de programa de incentivos e divulgação da imagem do Brasil no exterior. Agora, as viagens nacionais, o Turismo interno, foram estimulados por meio de vários fundos de investimentos regionais.

Vale ressaltar que nesta época, a EMBRATUR já vinha fazendo campanha, na tentativa de resgatar a imagem da cidade do Rio de Janeiro, abalada por notícias de violência veiculadas na mídia. De 1994 a 1995, período marcado pela tendência de segmentação do mercado, com o desenvolvimento da modalidade como Turismo 0, do país, em 1995, contribuiu para a eliminação de restrições a navios de bandeira estrangeira para realização de cruzeiros marítimos e fluviais na costa e rios brasileiros, dinamização da malha aérea e liberação dos vôos sub-regionais entre países integrantes do Mercosul.

Com o objetivo de criar condições para o produto turístico brasileiro, foi instalada a Câmara Setorial de Turismo, que visa trabalhar o Turismo de forma mais eficiente, com estratégias comuns entre o setor público e o trade.

De acordo com o Boletim da EMBRATUR (1988), as principais realizações da Câmara Setorial de Turismo foram: 
o PNMT - Programa Nacional de Municipalização do Turismo, reconhecido pela OMT por seu pioneirismo e melhor "case" de Turismo sustentável.

o Programa de combate à exploração do Turismo sexual infantojuvenil, cujo logotipo foi adotado como símbolo oficial da OMT.

o Programa "Embarque Nessa" nas escolas, com distribuição de 1 milhão de cartilhas, que ressaltavam a importância do patrimônio cultural e natural bem como o Turismo social.

o Criação da I e II fase do PRODETUR Nordeste, com projetos de investimentos em infra-estrutura básica (saneamento) e turística.

o Criação do PRODETUR Sul; programa de incremento do Turismo na região sul, aproveitando os recursos naturais existentes.

o Criação e instalação de comitês "Visite o Brasil" em Washington (EUA), Londres (Inglaterra), Buenos Aires (Argentina), Roma (Itália) e Paris (França) com objetivo de desenvolver o Turismo externo.

o Programa de Desenvolvimento Turístico, o primeiro a ser implementado com financiamento externo.

O Dr. Reinaldo Nunes (procurador aposentado da EMBRATUR) escreveu: "decorridos vinte anos de sua criação, a EMBRATUR pode afirmar que cumpriu e cumpre os objetivos para os quais foi concebida. Aceitou e decidiu favoravelmente o desafio que lhe foi imposto, tornando-se outro fator de progresso para o país e um elo na consolidação das propostas e metas da Nova República“.

A gestão que tomou posse em 1975 deu continuidade ao processo de modernização que a Empresa vinha passando, com investimentos na estruturação interna e no remanejamento das atribuições de suas Diretorias, criando uma nova, voltada ao planejamento da atividade turística, permitindo 
assim, melhor planejamento de suas ações e atuação. Entre as principais medidas tomadas, podemos ressaltar:

- A instituição de uma legislação turística específica e abrangente para o setor, a criação de novos critérios para a concessão de incentivos fiscais e regulamentação do FUNGETUR - Fundo Geral de Turismo, facilitando o acesso do pequeno e médio empresário turístico aos recursos oficiais.

- Início do processo de classificação dos hotéis, segundo critérios de conforto, serviços, preço e fiscalização - o que passa a definir categorias com classificação até cinco estrelas.

- Obrigatoriedade do registro na EMBRATUR das empresas exploradoras de atividades turísticas

- Elaboração de documento traçando, pela primeira vez, uma Política Nacional de Turismo.

A notória escassez de recursos para atividades promocionais foi habilmente minorada através da promoção, cooperação com o "trade" e convênios assinados com outras entidades públicas interessadas na promoção do Brasil no exterior. Dessa forma, a Empresa pode, além de outras iniciativas, constituir um estoque significativo e variado de material promocional dos principais recursos turísticos do País.

Simultaneamente à implantação de escritórios no exterior, visando apoiar a ação promocional da Empresa e a atuação junto às embaixadas do Brasil, o "trade" nacional passou a ter atuação marcante nos eventos comerciais internacionais, sob a liderança e coordenação da EMBRATUR.

Com respeito ao reconhecimento da importância econômica do Turismo, merece referência o ano de 1981, quando, pela primeira vez, foi incluindo no balanço de pagamentos o cálculo da receita turística efetuado pela EMBRATUR, a partir do gasto médio do turista, o que permitiu que o Turismo aparecesse nas contas nacionais com sua real e significativa contribuição. Até 
à época, o cálculo efetuado pelo Banco Central levava em conta apenas as despesas com viagens internacionais e troca de divisas no câmbio oficial.

Ressalta-se ainda, nesse período, a obtenção de recursos a fundo perdido, da Comunidade Econômica Européia - CEE, no valor de US\$ $500.000,00$, para a divulgação do produto turístico brasileiro nos países europeus; ocorrendo a operacionalização dos projetos de promoção.

De acordo com a publicação "EMBRATUR 40 Anos" (2006), os dados deste período, referentes ao Turismo são os seguintes:

- US\$700 milhões é o valor da receita brasileira em 1977, diante da saída de US\$ 887 milhões. Embora deficitária, a Conta Turismo Brasil apresenta, neste ano, sua primeira retração significativa desde a década de 1960;

- $5^{0}$ lugar no ranking das exportações brasileiras é ocupado pelo Turismo em 1979;

- 7.000 novos empregos são criados no setor turístico, com a construção de 2.289 novas unidades para hospedagem em 1983;

- $4^{\circ}$ lugar no ranking das exportações brasileiras é ocupado pelo Turismo em 1984;

- US\$1,5 bilhão e, 1,5 milhões de empregos são gerados pela indústria do Turismo nacional em 1985;

- $70 \%$ do parque hoteleiro no Brasil utilizam, via EMBRATUR, incentivos fiscais e financeiros em 1986. O número de hotéis chega a superávit na balança de pagamentos da Conta Turismo do Brasil, pela primeira vez, no período entre 1980 e 1989.

A Estrutura administrativa da EMBRATUR, em 1975/1988 (5a $6^{\mathrm{a}}$, $7^{\mathrm{a}} \mathrm{e}$ $8^{\text {a }}$ Gestões) era composta pelos cargos de presidência e 3 (três) diretorias; sendo que, em 10/10/1975, foi criada mais uma Diretoria. A Empresa 
Brasileira de Turismo - EMBRATUR estava sediada, inicialmente, na Praça Mauá, Prédio do INPI - Centro - Rio de Janeiro, sendo transferida em seguida para Praça da Bandeira, Tijuca - Rio de Janeiro. Os presidentes foram os Srs. Miguel Colasuonno, Hermógenes Teixeira Ladeira, Joaquim Affonso Mc Dowell Leite de Castro e João Dória Junior.

$\mathrm{Na}$ opinião dos empresários do setor, segundo Boletim Interno da EMBRATUR (1987), a atuação da EMBRATUR ao longo dos seus 20 anos teve mais acertos do que falhas e seu desempenho foi fundamental para tornar o Turismo uma atividade econômica importante para o país. Os empresários salientaram o trabalho da empresa com orientadora de investimentos, como órgão intermediário entre o governo e a iniciativa privada e como agente de formação da infra-estrutura turística brasileira, que nada fica a dever, em qualidade, ao padrão mundial.

A seguir, algumas opiniões de representantes do Turismo, em 1987, sobre o trabalho da EMBRATUR e o que os eles, à época, esperavam da empresa para os anos seguintes (EMBRATUR, 1988).

JOSÉ CARIBÉ DA ROCHA - presidente da Associação Brasileira da Indústria de Hotéis $(A B I H)$ - "A EMBRATUR é uma das coisas mais sérias que já foram feitas em nosso país. Se teve defeitos, isso não tira seus méritos. A EMBRATUR conseguiu despertar no governo o sentido de que o Turismo é um fator de alta relevância para a economia brasileira".

MANOEL VIEIRA - presidente da Associação Brasileira dos Transportadores Exclusivos de Turismo (ABRATT) - "Principalmente nos últimos anos, a EMBRATUR contribuiu significativamente para o desenvolvimento do nosso Turismo. Entre seus principais acertos está o projeto PASSAPORTE BRASIL, um verdadeiro marco em sua história, e a promoção feita nos últimos seis anos no exterior. Acho que um erro grave foi o fechamento de seus escritórios no exterior, o que quebrou a continuidade da promoção internacional do Brasil. Com todos os prós e contras, acho que a criação da EMBRATUR foi extremamente válida. E a empresa deveria até se transformar num ministério". 
JORGE BREOGAN RODRIGUES - presidente da Associação de Guias de Turismo do Brasil (AGTURB) - "Sem dúvida, a criação da EMBRATUR foi altamente necessária. É preciso existir um fórum de debates entre o governo e a iniciativa privada, algo que coordene todo o processo e a política nacional de Turismo. Aconteceram muitos erros, que agora estão sendo consertados. Talvez porque ela tenha, aos 20 anos, chegado à maturidade. Hoje, existe uma maior participação do empresariado na política de Turismo".

JOSÉ EDUARDO GUINLE - presidente da Associação de Hotéis de Turismo (AHT) - "Não sou uma testemunha ideal para dizer como era o setor de Turismo antes da criação da EMBRATUR, pois na época era muito jovem, tinha apenas 16 anos. A EMBRATUR veio dando, nesses anos, uma série de tropeços. Ela se transformou numa empresa burocrática e até hoje ainda incorpora alguns resquícios da época do arbítrio. Atualmente, a EMBRATUR está indo muito bem no marketing, na promoção; uma tarefa primordial. Mas, nesta fase de transição para todo o país, é o momento de repensar-lha como instituição, como empresa pública, orientadora de investimentos, catalisadora de incentivos fiscais, órgão de fomento de Turismo. É preciso retirar os vícios que ela possui e dar a importância que a EMBRATUR precisa ter. Aí, sim, estará preparada para durar mais 20 anos".

MÁRCIA VILLELA - presidente da Associação Brasileira dos Centros de Convenções e Feiras (ABRACEF) - "Nos últimos anos, o Turismo de congressos cresceu muito. E, sem dúvida, o apoio da EMBRATUR contribuiu para este crescimento. Se não houvesse uma entidade na orientação deste mercado, o resultado não seria tão bom. $O$ crescimento estupendo que vive hoje todo o setor turístico tem uma relação com o trabalho da EMBRATUR. Especificamente com relação à área de congressos, a EMBRATUR foi importante pelo incentivo na construção de diversos centros de convenções e na formação de uma infra-estrutura para este tipo de atividade".

JOSÉ MARIA EYMAEL - presidente da Associação Brasileira das Empresas Organizadoras de Congressos e Convenções (ABEOC) - "Vejo a EMBRATUR como um instrumento necessário no processo de desenvolvimento do Turismo nacional. Ela trouxe o espírito de profissionalismo 
à atividade no Brasil. Pode ter seus defeitos, mas o saldo é bastante positivo. No entanto, apesar dos esforços da EMBRATUR, ainda falta, efetivamente, um programa nacional de Turismo. E falta, também, uma política de incentivo, principalmente em relação à realização de novos congressos. Anualmente, há 600 congressos no país, mas poderíamos alcançar a casa dos 5 mil por ano".

WALDEMAR ALBIEN - presidente da Federação Nacional de Hotéis, Restaurantes, Bares e Similares - "aproximando-se o $20^{\circ}$ aniversário da EMBRATUR, queremos reiterar a expressão de nosso apreço pela tarefa que a entidade realizou, no passado, em benefício do Turismo brasileiro e, em especial, da hotelaria do país, para cuja ampliação e modernizações contribuíram decisivamente, ao lado do esforço da iniciativa privada do setor, os financiamentos por ela concedidos, via FUNGETUR e do FISET-Turismo. Desejamos, porém, mais do que relembrar o que já foi feito manifestar nossa confiança em sua atuação presente e futura; certos de que a EMBRATUR encontrará meio e modos de dar ao Turismo reais condições para que assuma seu papel no processo do desenvolvimento econômico e social do Brasil e da melhoria da qualidade de vida do povo brasileiro".

\section{3 - A EMBRATUR NAS DUAS ÚLTIMAS DÉCADAS (1997 - 2006)}

Vale destacar que o trabalho que a EMBRATUR vem desempenhando nesses 40 anos de existência, e sua atuação no desenvolvimento do setor, é parte integrante da própria história do Turismo brasileiro. Uma reflexão sobre sua trajetória histórica certamente resgatará fatos e apresentará contribuições importantes, visto que o Turismo vem se tornando um grande aliado no desenvolvimento econômico e social do país.

Em 28 de março de 1991, pela Lei no. 8.181, a autarquia passou à condição de instituto (Anexo 1). 
Art:; $1^{0}$ - A Empresa Brasileira de Turismo - EMBRATUR, autarquia especial, criada nos termos do art. 11 do Decreto-Lei $n^{\circ}$. 55, de 18 de novembro de 1966, passa a denominar-se EMBRATUR - Instituto Brasileiro de Turismo, vinculada à Secretaria do Desenvolvimento Regional da Presidência da República e responsável pela coordenação execução da Política Nacional de Turismo, competência do Conselho Nacional de Turismo - CNTur. Naquela ocasião, acumulava as funções de regulamentar o uso e a ocupação de áreas, estimulando o aproveitamento e preservação dos recursos turísticos naturais e culturais do país.. (Lei no. 8.181).

A alteração da denominação decorreu principalmente do fato de problemas jurídicos surgidos na administração da EMBRATUR, tanto junto ao Instituto de Administração Financeira da Previdência Social (IAPAS), quanto junto à Secretaria Municipal da Fazenda do Rio de Janeiro; devido à interpretação errônea daqueles órgãos relativa à personalidade jurídica da empresa.

O Decreto $n^{0}$. 2.079, de 26 de novembro de 1996, aprova a primeira Estrutura Regimental e a competência das unidades organizacionais e o Quadro Demonstrativo dos Cargos em Comissão Gratificada do Instituto. Remaneja os cargos comissionados e funções gratificadas do Ministério da Administração Federal e Reforma do Estado para a EMBRATUR e do Instituto para o Ministério referido.

Coube à EMBRATUR, vinculada então ao Ministério do Esporte e Turismo, a responsabilidade integral pela Política Nacional do Turismo, que representa "... a atividade decorrente de todas as iniciativas decorrentes de todas as atividades ligadas à indústria do Turismo, sejam elas originárias de setor privado ou público, isoladas ou coordenadas entre si" (Decreto-lei $\mathrm{n}^{\circ}$. $55 / 66)$.

Em 1999, o Governo Federal cria o Ministério do Esporte e Turismo, ao qual fica vinculada a EMBRATUR como autarquia especial do governo, com a função de elaborar e executar a Política Nacional de Turismo. 
De acordo com a publicação "EMBRATUR 40 Anos" (2006), as principais realizações no decorrer da década de 90 foram:

- Criação do comitê gestor do Programa Pólos de Ecoturismo do Brasil; investimentos na divulgação de informações sobre o ecoturismo, com lançamento de site sobre o tema;

- Criação do Projeto Jovens Embaixadores, que promoveu o Brasil no exterior, aproveitando o potencial de divulgação dos 40 mil estudantes que saem anualmente do país;

- Realização de Fóruns Empresariais sobre a Indústria do Turismo, em parceria com bancos internacionais em Roma (Itália), Lisboa e Estoril (Portugal);

- Realização do seminário "Políticas Públicas, Programa Nacional de Municipalização do Turismo e Fundo do Turismo no Brasil"; evento que integra o Projeto para o Desenvolvimento do Pensamento Estratégico do Turismo Brasileiro;

- Abertura do mercado e o abandono do controle tarifário; a política de competição antes controlada, caracterizada por uma forte intervenção estatal no controle de rotas e tarifas e vigente desde os anos 60 , é gradativamente abandonada;

- A década também traz a estabilidade financeira, após 1994, e a incorporação definitiva de discussões fundamentais, como as questões do desenvolvimento sustentável e da valorização do multiculturismo.

O Turismo é uma atividade em expansão. Diante da abertura do mercado global, o mundo encontra-se em constantes transformações, muda-se o foco das organizações em busca da eficiência nos processos e nas atividades. Essa evolução traz novas formas de gestão, tanto nas instituições privadas quanto nas públicas, motivadas pelos modelos de gestão de países 
desenvolvidos, como Espanha, Portugal e França. Com a criação do Ministério do Turismo em janeiro de 2003, a EMBRATUR passou a ter um novo modelo de gestão com a responsabilidade de cuidar exclusivamente da promoção comercial do Turismo brasileiro no exterior.

Parte das competências do Instituto são transferidas para este ministério e distribuídas a quatro órgãos específicos: a Secretaria de Políticas de Turismo, responsável pela política nacional de desenvolvimento do Turismo; a Secretaria de Programas de Desenvolvimento do Turismo, destinado a estimular as iniciativas públicas e privadas de incentivo às atividades turísticas; o Conselho Nacional do Turismo, teve a iniciativa de propor diretrizes e oferecer subsídios técnicos para formulação e acompanhamento da Política Nacional do Turismo" (Plano Nacional do Turismo, 2003/2007). Ao Instituto Brasileiro de Turismo, (que sempre esteve à frente do Turismo brasileiro, sendo responsável pelas políticas públicas do Turismo, cabendo a ele, fomentar, divulgar e até mesmo financiar a infra-estrutura turística do país), cabe, atualmente, um novo papel e um foco específico: a promoção e comercialização do Brasil no exterior, cujo objetivo é a consolidação da imagem do Brasil no exterior.

Com a intensificação em planejamento estratégico, o desenvolvimento e implementação do Plano Aquarela - Marketing Turístico Internacional do Brasil e a Marca Brasil passaram a nortear e dar unidade às ações da EMBRATUR.

A partir de 2003, com a mudança de foco e a revitalização de alguns programas já realizados em gestões passadas, as principais realizações da EMBRATUR, foram:

- Levantamento e ordenação de todos os dados estatísticos e indicadores sobre o Turismo brasileiro;

- Criação do Projeto Caravanas Brasil, com o objetivo de trazer ao país operadoras internacionais de Turismo; 
- Reformulação dos escritórios de representação da EMBRATUR no exterior, criados no início da década de 80 . Abertura de novos escritórios, tendo como objetivo a captação de um número maior de turistas.;

- Criação do Projeto Excelência em Turismo;

- Divulgação da campanha "Brasil. Quem conhece vira fã!", com objetivo de estimular o Turismo brasileiro nos Estados Unidos e em países da América do Sul e Europa;

- Realização do I Seminário Catarinense de Relacionamentos com o Turista Estrangeiro;

- Lançamento do programa "Agentes de Viagens Especialistas em Brasil", que tem como objetivo a formação on-line de agentes de viagens que trabalham com o destino Brasil, nos mercados Português, Espanhol, Americano, Colombiano e Chileno;

- Revisão e atualização do Plano Aquarela - Marketing Turístico Internacional.

A Estrutura administrativa da EMBRATUR, em 1988/2006 (9a $10^{\mathrm{a}}, 11^{\mathrm{a}}$, $12^{\mathrm{a}}, 13^{\mathrm{a}}, 14^{\mathrm{a}}, 15^{\mathrm{a}}$ e $16^{\mathrm{a}}$ Gestões) era composta pelos cargos de presidência e 4 (quatro) diretorias; sendo que na $11^{\mathrm{a}}$ gestão foi extinta uma Diretoria. A sede da Empresa Brasileira de Turismo - EMBRATUR que era sediada, à época, na Praça da Bandeira, Tijuca - Rio de Janeiro, foi transferida para Brasília em 1992. Os presidentes foram os Srs. Pedro Grossi, Ricardo Mesquita de Faria, Ronaldo Monte Rosa, Lúcio Bello de Almeida Neves, Flávio José de Almeida Coelho, Caio Luiz Cibella de Carvalho e Luiz Otávio Caldeira Paiva. Atualmente a gestora $\left(17^{\mathrm{a}}\right)$ da empresa é a Sra. Jeanine Pires.

De acordo com a publicação "EMBRATUR 40 Anos" (2006), os dados referentes ao Turismo nesse período são os seguintes: 
- 30 mil visitantes participam da Eco-92 na cidade do Rio de Janeiro;

- 500 milhões de viagens e receita de US\$304 bilhões são registrados pelo Turismo mundial em 1993;

- $28^{\circ}$ lugar no ranking da Organização Mundial de Turismo (OMT) é ocupado pelo Brasil, em 2000, como destino mais procurado no mundo. O país ocupava a $43^{a}$ colocação em 1994;

- 1.099 projetos, com custo de cerca de US\$ 399 milhões, são financiados pelo FUNGETUR nos anos de 1976 a 1989 Neste período, são gerados 19.962 empregos no setor e 16.049 novos quartos de hotéis.. O FUNGETUR ficou sem verba a partir de 1989;

- $3^{\circ}$ lugar no ranking das exportações brasileiras é ocupado pelo Turismo em 1999, com participação de 4\% do Produto Interno Bruto (PIB) do país;

- US\$ 3,4 trilhões é o faturamento do Turismo em 2002, com participação de $10 \%$ do Produto Interno Bruto (PIB) mundial e geração de 205 milhões de empregos.

A EMBRATUR hoje, corresponde às especificidades do Decreto $\mathrm{n}^{\circ}$. 4.672, de 16 de abril de 2003 (ANEXO I), através do qual sofreu sua última modificação. A partir desta modificação, a empresa passou a voltar suas ações e esforços apenas para o mercado externo, tendo como missão a promoção, as ações de marketing e o apoio à comercialização dos produtos brasileiros no exterior.

De acordo com o Plano Nacional do Turismo - PNT caberá à EMBRATUR executar no período de 2003 a 2007:

- A elaboração e implantação do plano de marketing para o Turismo brasileiro; 
- A definição e execução da política de ações promocionais e apoio à comercialização dos produtos turísticos;

- A formatação e organização de novos produtos e roteiros turísticos integrados e

- A elaboração de estudos e pesquisas que orientem os processos de tomada de decisão e avaliem o impacto da atividade turística na economia nacional. 


\section{5 - ATRIBUIÇÕES DA EMBRATUR DE 1966 A 2006}

A EMBRATUR foi criada com o objetivo de formular e responder pelo Desenvolvimento da Política Nacional de Turismo. Nos seus primeiros vinte (20) anos, a prioridade foi a criação de toda a infra-estrutura necessária ao desenvolvimento da atividade e sua normatização. Foi também definida a Política Nacional de Turismo, sendo que a cada governo essa política vem sendo aperfeiçoada, de acordo com as necessidades do mercado, com a participação dos secretários de estado e Turismo, das entidades de classes, de universidades, dos Convention Bureau e da cadeia produtiva do Turismo.

\section{1 - ATRIBUIÇÕES}

O mesmo Decreto-lei $n^{\circ}$. 055/66, que criou a EMBRATUR, também definiu nesse Decreto, as atribuições e responsabilidades da EMBRATUR, baseadas na Política Nacional de Turismo, que são:

- Fomentar e financiar diretamente iniciativas, planos, programas e projetos que visem o desenvolvimento da indústria do Turismo;

- Estudar de forma sistemática e permanente o mercado turístico, de maneira a obter os dados necessários à formulação de políticas de Turismo;

- Organizar, promover e divulgar as atividades ligadas ao Turismo;

- Registrar e fiscalizar as empresas do setor.

Com a alteração sofrida pelo Art. 57 da Lei no .8 .028 de 12 de abril de 1990 e pela Lei no. 8.181 de 28 de março de 1991, vinculada, à época, ao 
Ministério da Indústria, do Comércio e do Turismo, a EMBRATUR tinha por finalidade formular, coordenar, executar e fazer executar a Política Nacional de Turismo e estimular o desenvolvimento das atividades ligadas ao Turismo, como:

- Propor ao Governo Federal normas e medidas necessárias à execução da Política Nacional de Turismo e executar as decisões que, para este fim, Ihe eram recomendadas;

- Estimular as iniciativas públicas e privadas, tendentes a desenvolver o Turismo interno e do exterior para o Brasil;

- Promover e divulgar o Turismo nacional, no país e no exterior, de modo a ampliar o ingresso e a circulação dos fluxos turísticos no território brasileiro;

- Analisar o mercado turístico e planejar o seu desenvolvimento, definindo áreas, empreendimentos e ações prioritárias a serem estimuladas e incentivadas;

- Fomentar e financiar, direta ou indiretamente, as iniciativas, planos, programas e projetos que visem o desenvolvimento do Turismo, controlando e coordenando a execução de projetos considerados de interesse para o setor;

- Estimular e fomentar a ampliação, diversificação, reforma e melhoria da qualidade da infra-estrutura turística nacional;

- Definir critérios, analisar, aprovar e acompanhar os projetos de empreendimentos turísticos que sejam financiados ou incentivados pelo Estado.

Para melhor entendimento dessa seção pode-se observar que antes do Governo Lula, em 2003, a EMBRATUR foi responsável pelas diretrizes do Turismo Nacional, cabendo a ela, principalmente, normatizar e formalizar as políticas do Turismo e também por todos os assuntos relacionados ao Turismo no âmbito Federal. 
Juntamente com a EMBRATUR, foi criada a Política Nacional de Turismo e nos primeiros dez anos, a EMBRATUR cuidou de incentivos e fiscalização das agências de viagens. Aos 20 anos foi quando foram iniciadas a divulgação e promoção do Brasil no exterior, com eventos e feiras de negócios, pois anteriormente ela só tinha orçamento para seu custeio.

\section{2 - GESTÃO DA EMBRATUR (1967 - 2007)}

Os responsáveis pelas diferentes faces que o Instituto revelou ao longo de sua história, que na sua maioria contribuíram para delinear seu atual perfil como condutora da política do Turismo nacional foram:

JOAQUIM XAVIER DA SILVEIRA (1967 - 1971) - Advogado, o primeiro presidente da EMBRATUR dedicou-se à organização da empresa e à implantação de seus serviços básicos. Em sua administração, foram realizadas a elaboração e a sistematização de um conjunto expressivo de normas necessárias à aplicação de incentivos e ao adequado registro e fiscalização das agências de viagens. Foi durante sua gestão que se deu início à aprovação de projetos e à construção de hotéis de nível internacional no país, bem como o do maior centro internacional de feiras e convenções nacional, o Anhembi, em São Paulo. Com uma profunda carência de recursos, que caracterizou toda a sua administração, foi o esforço de planejamento global para o setor. Após deixa a EMBRATUR, publicou o livro "Turismo Prioridade Nacional" e passou a dedicar-se à iniciativa privada.

CARLOS ALBERTO ANDRADE PINTO (1971) - Sua administração, embora curta (menos de um ano), trouxe duas contribuições de relevo para o setor turístico. A primeira foi a aplicação de parte dos recursos oriundos de incentivos fiscais, retidos no Banco do Brasil, revertendo o rendimento da aplicação no custeio das despesas da EMBRATUR. A segunda contribuição foi a promulgação do decreto-lei $n^{\circ}$. 1.191/71 que, entre outras providências, criou o Fundo Geral de Turismo - FUNGETUR. Economista, Carlos Alberto Andrade 
Pinto trabalhou com o então ministro Delfim Netto durante o governo Costa e Silva e foi presidente também do Instituto Brasileiro do Café (IBC). Após deixar a EMBRATUR, voltou às atividades empresariais.

PAULO MANOEL PROTÁSSIO (1972 - 1975) - Em sua gestão houve a estruturação interna da empresa, a definição de sua programação básica e a projeção da imagem da EMBRATUR no país e no exterior. Em 1973 foi instituído, pela primeira vez, o Ano Nacional do TURISMO e lançado o programa "Conheça o Brasil", para intensificar o Turismo interno. Também em sua gestão, foi criado o "Vôo de TURISMO Doméstico", para excursões em grupo, com descontos e dado o primeiro passo para a ordenação do uso do solo e dos recursos turísticos. Com seu passado vinculado à iniciativa privada, o advogado Paulo Protássio pertenceu também ao Conselho de Desenvolvimento Comercial do Ministério da Indústria e do Comércio.

SAID FARHAT (1975 -1979) - Foi neste período que a EMBRATUR passou a ter nova estruturação, com a criação de diretorias de planejamento, de investimentos e de operações. Outras mudanças ocorreram em sua administração: em 1977, por exemplo, tornou-se obrigatório o registro na EMBRATUR das empresas exploradoras de atividades turísticas, como os meios de hospedagem, as agências de Turismo e as transportadoras turísticas, entre outros. Em sua gestão, ainda conseguiu que o poder público federal tomasse consciência da importância de se promover a preservação do equilíbrio cultural, natural e social dos locais turísticos. Foi no decorrer de sua gestão que se iniciou a participação do "trade" nacional, de forma sistemática, nos principais eventos comerciais no exterior. Said Farhat, jornalista, publicitário e advogado, foi presidente e diretor-responsável do grupo Visão, diretor-geral da Editora Abril e, ao sair da EMBRATUR, ocupou o cargo de Ministro-Chefe da Secretaria de Comunicação Social, no governo João Baptista Figueiredo.

MIGUEL COLASUONNO (1979 - 1984) - Economista, ex-prefeito de São Paulo e assessor do Ministério do Planejamento durante o governo de Ernesto Geisel, Miguel Colasuonno (Anexo 3) teve como primeiro desafio à sua administração a necessidade de incrementar fontes alternativas de recursos 
para o FUNGETUR, depois que o depósito compulsório sobre as viagens ao exterior foi extinto. Em sua gestão, a EMBRATUR entrou na era da informatização, permitindo a agilização da obtenção de informações, a implantação e o controle da ficha nacional de registro de hóspedes e a elaboração do boletim de ocupação hoteleira, instrumentos importantes para o acompanhamento e estudo dos fluxos turísticos do país. A principal meta desta administração, no entanto, foi a promoção do país na América Latina, Estados Unidos e Europa. Além disso, houve a promoção do Turismo interno, para as classes menos privilegiadas, e o reconhecimento da importância econômica da atividade. No período de 1979 a 1986, a criação dos "Portais do Nordeste" levou turistas estrangeiros a conhecer belezas do nosso país, até então não exploradas, como Fortaleza, Belém, Recife e Salvador. O principal desafio de gestão foi a "guerra de tarifas", quando foram criadas tarifas de incentivos (Pacotes de Turismo), que foram um grande sucesso. Na sua gestão foram abertos escritórios de representação nos Estados Unidos (Nova York), Alemanha (Frankfurt) e França (Paris). A principal marca de sua gestão foi a profunda transformação do setor turístico-econômico, com a integração de agentes de viagens e companhias aéreas, movimentando a economia brasileira, sem questionar o lado cultural (ter nas mãos a própria solução antes pouco divulgada).

HÉRMOGENES TEIXEIRA LADEIRA (1984 - 1985) - Sua gestão foi a mais curta da história da EMBRATUR (apenas três meses), e teve caráter de transição. Empresário, advogado e jornalista, Ladeira, apesar do pouco tempo em que dirigiu a empresa, elaborou um amplo diagnóstico sobre as atividades da EMBRATUR e forneceu subsídios sobre o setor de Turismo para o governo da Nova República.

JOAQUIM AFFONSO MAC DOWELL LEITE DE CASTRO (1985 1986) - Também à frente da EMBRATUR por curto espaço de tempo, Mac Dowell foi responsável pela elaboração de proposta da Política Nacional de Turismo, posteriormente homologada na gestão seguinte pelo Conselho Nacional de Turismo - CNTur, que traçou os objetivos e metas do Turismo, de acordo com as diretrizes do $1^{\circ}$ Plano Nacional de Desenvolvimento da Nova 
República. Com atividade no setor privado de Turismo - é um dos diretores dos Caminhos Aéreos Pão de Açúcar - Mac Dowell cumpriu cinco mandatos como vereador, deputado estadual e deputado federal e, ao deixar a EMBRATUR, assumiu sua cadeira de deputado federal, cargo do qual era suplente.

JOÃO DÓRIA JÚNIOR - (1986 - 1988) - Nos primeiros sete meses de sua gestão, a nova administração da EMBRATUR reorganizou a empresa para adaptá-la ao máximo de eficiência empresarial. Inaugurou o marketing, em termos profissionais. No Anexo IV constando os folders de algumas das campanhas realizadas. NOS primeiros oito meses de sua gestão, os resultados desse ritmo de trabalho foram notórios: João Dória (Anexo III) e sua equipe, com idade média de trinta anos, se empenharam em desenvolver projetos, dentre os quais se podem destacar: a implantação do Programa "Passaporte Brasil", como agente estimulador para ampliação de viagens dentro do Brasil, reduzindo o custo do transporte aéreo e de hospedagem em 40\%. Esse programa contava com a participação de shoppings centers e empresas de receptivo, sempre oferecendo vantagens para viagens de dois ou mais dias pelo País. O "Passaporte Brasil" recebeu uma menção especial da Organização do Turismo, pela eficiência e criatividade da iniciativa de estímulo ao turismo doméstico.

O "Passaportezinho Brasil", voltado para o estímulo às viagens educacionais pelo Brasil, para que as crianças do ensino básico pudessem conhecer melhor a História e a Geografia do seu País, além do comportamento e das características do seu povo, por meio de viagens pelo Brasil, fora dos períodos de férias. Este programa recebeu elogios da Unesco, pela forma ousada e criativa de ampliar a oportunidade de ensino, para diferentes segmentos da população, para o público de seis a 17 anos.

O "Clube da Maioridade", programa dirigido para pessoas com idade acima de 60 anos voltado para estimular o turismo nas baixas estações, valorizando o turismo rodoviário. Esse programa serviu de base para várias ações regionais em todo o País. 
Trazendo uma experiência vitoriosa da Europa, especialmente da Alemanha, para ser introduzido no Brasil, foi lançado o programa "Albergues da Juventude". Em menos de dois anos foram implantados com o apoio do setor privado mais de 60 Albergues da Juventude nas regiões Sul, Sudeste, CentroOeste e Nordeste do Brasil para estimular o turismo barato, fraterno e integrado através desses meios de hospedagem. Foi um programa vitorioso, que até hoje se mantém ativo em todo o Brasil com centenas de albergues operantes em todas as regiões brasileiras.

Para estimular viagens rodoviárias e aéreas aos deficientes físicos, foi lançado o "Turismo para Portadores de Deficiência", população essa que representa $10 \%$ do total de habitantes do Brasil. Com o programa foram estimulados hotéis, empresas aéreas e de turismo rodoviários a terem a oportunidade de oferecer programas e facilidades de acesso e deslocamento para deficientes.

Vale mencionar também a campanha que foi elaborada após as chuvas e inundações que o Rio de Janeiro sofreu em 1986 e que quase paralisaram a cidade. Em menos de 15 dias foi desenvolvida a campanha "O Rio continua lindo", com o apoio de veículos de comunicação eletrônica e impressa para promover o Rio de Janeiro como destino turístico nacional e resgatar a autoestima dos cariocas em relação à sua cidade. Estes programas deram início à profunda remodelação da atividade turística nacional. Sua gestão também deu um novo ritmo de atuação ao setor de Turismo internacional, com a abertura dos escritórios de Turismo do Brasil em Nova York, Buenos Aires, Paris e Londres, juntamente com o Ministério da Indústria e do Comércio e com o apoio das embaixadas brasileiras. Numa iniciativa inédita, a Comunidade Econômica Européia concedeu recursos para financiamento de programas de promoção do Brasil na Europa. Graças a estes recursos foi lançado o projeto "Discover Brazil" e pode-se realizar participações nas principais feiras de Turismo do velho continente.

Com uma participação mais ativa, uma presença mais constante e inventiva nas feiras e eventos no exterior, começou a consolidar a nova imagem do Brasil no mercado internacional. Ao tomar posse em 86, João Dória 
júnior, aos 28 anos, assumia o cargo como o oitavo e mais jovem presidente da EMBRATUR. Jornalista, publicitário e professor de marketing da Faculdade de Comunicação da FAAP-SP; voltou as suas atividades empresariais ao deixar a EMBRATUR.

PEDRO GROSSI JÚNIOR - (1988 - 1989) - Sua gestão foi de continuidade dos programas implementados pela gestão anterior, tendo como principais realizações: Investimento no projeto Disque Turismo, Criação do Sistema Oficial de Turismo, com incremento da base de dados e informações sobre o setor, recriação da diretoria de Planejamento na EMBRATUR, Investimentos no programa Passaportezinho Brasil e a Criação do Passaporte Brasil Grupo.

RONALDO DO MONTE ROSA - (1990 - 1992) - Administrador, primeiro agente de viagens a presidir a EMBRATUR. Teve como um dos principais objetivos, a criação de uma política de orientação da indústria turística e com ênfase na ecologia, apresentou o plano "Estratégia para o Desenvolvimento do Turismo no Brasil". Suas principais realizações foram: desregularização das tarifas aéreas domésticas, como forma de incentivo ao Turismo interno; lançamento do programa Ecoturismo; lançamento da campanha de promoção turística com o tema "Brasil, mostra a sua tua cara". Foi na sua gestão que, por meio de um Decreto do Presidente Collor, houve a transferência da sede do Rio de Janeiro para o Distrito Federal.

LUCIO BELLO DE ALMEIDA NEVES (1992 - 1993) - Em sua gestão o advogado Lúcio Neves teve como prioridade os investimentos na captação de turistas estrangeiros, por meio de programa de incentivos e divulgação da imagem do Brasil no exterior. E as viagens nacionais, o Turismo interno, são estimuladas por meio de vários fundos de investimentos regionais. Suas principais realizações foram: criação do manual de instruções para obtenção de recursos provenientes dos fundos de financiamento para a atividade turística, como o Fundo Nacional de Turismo (FUNGETUR), Fundo de Investimentos do Nordeste (FINOR), Fundo Constitucional de Financiamento do Norte (FNO) e linha de financiamento do BNDES (FINAME), além da tentativa de resgatar a 
imagem da cidade do Rio de Janeiro, abalada por notícias de violência veiculadas na mídia.

FLÁVIO JOSÉ DE ALMEIDA COELHO (1994 -1995) - A estabilidade econômica do País contribuiu para que na sua gestão fossem eliminadas restrições a navios de bandeira estrangeira para realização de cruzeiros marítimos e fluviais na costa e rios brasileiros pela abertura dos portos. A tendência de segmentação do mercado, com o desenvolvimento da modalidade como Turismo rural e o Turismo saúde também foram marco de sua gestão. O Ministério da Indústria, Comércio e Turismo, juntamente com o Ministério do Meio Ambiente elaboraram uma Política Nacional de Ecoturismo, a partir de então o Turismo é visto em seu potencial de desenvolvimento social e sustentabilidade econômica ecológica. Pode-se destacar também um programa especial para conscientização de autoridades e sociedade de modo geral em torno do setor - Tratar o turismo com seriedade e como forma de gerar emprego e renda - Campanha realizada em todo o País, com participação de prefeitos, governadores e autoridades do Governo Federal. Ao deixar a EMBRATUR, assumiu o cargo de Secretário de Turismo de Blumenau - SC.

CAIO LUIZ CIBELLA DE CARVALHO (1995 - 2002) - Formado em Direito, o advogado Caio Carvalho, teve a gestão mais longa da história da EMBRATUR, administrou a empresa por 8 anos, ao deixar a EMBRATUR assumiu o cargo de Ministro do Esporte e Turismo. Atualmente é Presidente da SPTuris, principal órgão de Turismo da cidade de São Paulo. Sua gestão foi marcada pela dinamização da malha aérea e liberação dos vôos sub-regionais entre os países integrantes do Mercosul. Foi instalada a Câmara Setorial de Turismo, cujo objetivo foi criar condições para que o produto turístico brasileiro seja trabalhado de forma mais eficiente, com estratégias comuns entre o setor público e o trade. Suas principais realizações foram: criação do Programa Nacional de Municipalização do Turismo (PNMT), reconhecido em 1998 pela Organização Mundial de Turismo (OMT) por seu pioneirismo e melhor "case" do Turismo sustentável; programa de combate à exploração do Turismo sexual infanto-juvenil. O logotipo criado pela campanha brasileira foi adotado como 
símbolo oficial da Organização Mundial de Turismo, Criação do programa "Embarque Nessa" nas escolas, com distribuição de 1 milhão de cartilhas que ressaltavam a importância do patrimônio cultural e natural bem como do Turismo social. Planejamento do Turismo Segmentado. Pesquisa sobre o Turismo emissivo e receptivo internacional. Criação da primeira e segunda fases do PRODETUR Nordeste, com projetos de investimentos em infraestrutura básica (saneamento) e turística, Criação do PRODETUR Sul, programa de incremento do Turismo na região sul, aproveitando os recursos naturais existentes, Desenvolvimento do Turismo externo por meio da instalação de comitês "Visite o Brasil" em Washington (Estados Unidos), Londres (Inglaterra), Buenos Aires (Argentina), Roma (Itália) e Paris (França), Criação do Programa de Desenvolvimento Turístico, o primeiro a ser implementado com financiamento externo. Também, a elaboração de vários guias, como: Roteiros de Pesca Esportivas no Brasil (resultado do Programa Nacional de Desenvolvimento da Pesca Amadora), Guia de Parques Nacionais e Guia Brasileira de Sinalização Turística.

LUIZ OTÁVIO CALDEIRA PAIVA (2002 - 2003) - Funcionário concursado do Banco Central, Luiz Otávio esteve frente à EMBRATUR por curto espaço de tempo. A administração de Luiz Otávio foi responsável pela realização de campanhas promocionais e pesquisas com o objetivo de identificar e ampliar o número de consumidores dos produtos turísticos brasileiros, com o intuito de expandir o mercado e transformar o Turismo em ferramenta de crescimento econômico e desenvolvimento social. Suas principais realizações foram: Criação do comitê gestor do Programa Pólos de Ecoturismo do Brasil; Investimentos na divulgação de informações sobre Ecoturismo, com lançamento de site sobre o tema; Criação do Projeto Jovens Embaixadores, que promoveu o Brasil no exterior, aproveitando o potencial de divulgação dos 40 mil estudantes que saem anualmente do país; Realização de Fóruns Empresariais sobre a indústria do Turismo, em parceria com bancos internacionais em Roma (Itália), Lisboa e Estoril (Portugal); Realização do seminário "Políticas Públicas, Programa Nacional de Municipalização do Turismo e o Fundo do Turismo no Brasil", evento que integra o Projeto para o Desenvolvimento do Pensamento Estratégico do Turismo Brasileiro. 
EDUARDO SANOVICZ (2003 - 2006) - Formado em História, Eduardo Sanovicz implementou o novo modelo da EMBRATUR determinado pelo Ministério do Turismo (Promoção e Divulgação no exterior). Dando uma nova roupagem a alguns programas já realizados em gestões passadas com vistas ao momento atual e intensificando-se os focos em planejamento estratégico $O$ Plano Aquarela - Marketing Turístico Internacional do Brasil e a Marca Brasil passaram a nortear e dar unidade às ações da EMBRATUR.

Suas principais realizações foram: Levantamento e ordenação de todos os dados estatísticos e indicadores sobre o Turismo brasileiro, Projeto Caravana Brasil, com o objetivo de trazer ao país, operadores internacionais de Turismo, Reformulação dos escritórios de Representação da EMBRATUR no exterior (pois em gestões passadas, já existiam essa representações), Projeto Excelência em Turismo, Divulgação da campanha "Brasil. Quem conhece vira fã!", com objetivo de estimular o Turismo brasileiro nos Estados Unidos e em países da América do Sul e Europa, Desenvolvimento e implementação do Plano Aquarela - Marketing Turístico Internacional do Brasil e a Criação da Marca Brasil. Após deixar a EMBRATUR, voltou a suas atividades empresariais.

JEANINE PIRES (2006-2007) - Primeira mulher na presidência da EMBRATUR, desde a sua fundação, ex-diretora de Turismo de Negócios e Eventos. Formada em História, professora concursada do Estado de Alagoas. Sua gestão vem dando continuidade às metas estabelecidas pelo Ministério do Turismo, intensificando a promoção do Turismo brasileiro no exterior. Suas principais realizações: I Seminário Catarinense de Relacionamento com o Turista Estrangeiro, Lançamento do Programa Agentes de Viagens Especialistas em Brasil em Portugal, Espanha, Estados Unidos, Colômbia e Chile. O programa tem como objetivo a formação on-line de agentes de viagens que trabalham como destino Brasil, Revisão e atualização do Plano Aquarela - Marketing Turístico Internacional do Brasil, Instituição da Inteligência de Mercado - conjunto de ações estratégicas com objetivo de preparar o trade nacional para trabalhar com os dez principais mercados de interesse do Turismo brasileiro. 


\section{6 - A TRAJETÓRIA DA EMBRATUR NA VISÃO DE LIDERANÇAS, DIRI- GENTES E FORMADORES DE OPINIÃO DA ÁREA TURÍSTICA.}

Nesta seção é apresentada uma síntese das respostas obtidas através do envio de questionários (Apêndices I e II) aos ex-presidentes da EMBRATUR, jornalistas especializados em Turismo e lideranças de entidades de classe integrantes da atividade turística. Vale ressaltar que dos 20 (vinte) questionários enviados, obteve-se resposta de apenas 15, cujas opiniões fundamentam esta seção.

Segundo opinião de alguns dos entrevistados, mais especificamente os ex-presidentes das entidades de Turismo e os jornalistas de Turismo, a EMBRATUR, durante mais de três décadas, foi responsável pelas políticas de desenvolvimento do Turismo no país, papel hoje desempenhado pelo Ministério do Turismo. Eles são de opinião de que a EMBRATUR, com o seu novo papel, na promoção do Brasil deva dar continuidade ao trabalho que vem sendo desenvolvido, visto que o mercado internacional é sensível a mudanças bruscas.

$\mathrm{Na}$ opinião de alguns servidores, que vivenciaram ou ainda continuam fazendo parte desta história, a EMBRATUR passou por vários momentos diferentes ao longo desses 40 anos, alternando altos e baixos, sucessos e insucessos, erros e acertos. Evidentemente que essa instabilidade impactou em sua missão, enquanto órgão máximo do Turismo nacional, quando ainda nem se pensava na criação de um Ministério do Turismo.

Os momentos de estagnação foram vivenciados, principalmente após as fases de gestões competentes, como a do presidente Miguel Colasuonno (ápice dos investimentos em equipamentos e infra-estrutura) e do presidente João Dória (ápice do marketing).

Após a atuação do Senhor João Dória, a EMBRATUR sofreu um retrocesso, tanto administrativo, como de atuação, por um longo período em que prevaleceu a gestão política em detrimento da gestão técnica. Como 
momento crucial, desta estagnação, sem dúvida pode ser citada a mudança da sede para Brasília. Isso, de fato, pôs um ponto final na estrutura de 25 anos, de um quadro técnico competente e da própria credibilidade perante o trade turístico, inclusive tendo como momento marcante a desregulamentação do setor.

Ao longo da década de 90, em função da mudança para Brasília, a EMBRATUR passou por renovação do seu quadro de servidores. Isso implicou na desaceleração, estagnação ou mesmo abandono de determinados programas. Com a estagnação, em patamares bastante significativos, o desenvolvimento do Turismo dependia-se quase que exclusivamente das conjunturas econômicas e forças de mercado.

A EMBRATUR em determinados períodos não cumpriu com o seu papel ou teve atuação irrelevante, limitadas as rotinas de seu papel cartorial, hoje transferido para o MTur. Se assim não o fosse, constataríamos que "quarenta anos" fora tempo, mais do que suficiente, para colocar o Brasil em posição de destaque no panorama turístico mundial, o que a instituição não fez.

Os seus velhos concorrentes prosperaram ainda mais e assistimos ao crescimento de novos destinos, fazendo-nos amargar o "ranking" de 90a posição, na questão da segurança, segundo o Fórum Econômico Mundial:

Segundos dados do Centro de Excelência em Turismo da Universidade de Brasília (CET/UnB, 2006),

\footnotetext{
"Em estudo comparativo sobre a competitividade turística dos diferentes países, o Fórum Econômico Mundial apresenta o Brasil em $59^{\circ}$ lugar. Para essa posição, contou negativamente, com destaque, a questão segurança, onde alcançamos a $90^{a}$ posição. Estudo sobre a economia do Turismo no Brasil, do Núcleo de Economia do Turismo (NET), pertencente ao Centro de Excelência em Turismo (CET), da Universidade de Brasília, chama também a atenção para o problema ao constatar que a violência é um dos fatores que exerce maior impacto negativo sobre a demanda turística no Brasil. O efeito de um homicídio por grupo de 100 mil habitantes reduz em 580 visitantes a demanda por Turismo nos municípios analisados".
} 
Impossível, até então, não compreender a resposta óbvia para a questão: porque o Turismo não decola no Brasil? (matéria da revista Época de 1998).

A criação de uma política nacional de Turismo foi o início de um processo de mudança de postura em relação à atividade no país e, claro, da própria missão da EMBRATUR, tanto no âmbito público como no privado. Ainda que em passos lentos, e também sob a intervenção, ainda, de mandos "políticos" na ocupação de cargos estratégicos e devidamente loteados por interesses partidários, a EMBRATUR levanta uma bandeira importante no processo de consolidação do setor: primeiro, colocando o Turismo enquanto atividade econômica e, segundo, a sensibilização do poder público sobre a necessidade de seguir um planejamento estratégico com propostas exeqüíveis de programas e projetos orientados por uma Política Nacional de Turismo estruturante.

Ressalta-se, neste contexto, o Programa Nacional de Municipalização do Turismo, no qual o processo de sensibilização e mobilização dos atores envolvidos direta $\mathrm{e}$ indiretamente na atividade turística possibilitou $\mathrm{o}$ reconhecimento do papel de cada um no desenvolvimento do Turismo no país. Momento em que o Turismo passou a ser compreendido não somente como promoção de destinos, mas como gerador de emprego e renda, como fator de desenvolvimento de localidades e regiões e como agregador de valores intrínsecos a identidade cultural do povo brasileiro.

Em que pese os desvios desse processo, a EMBRATUR colheu frutos positivos e, atualmente está desempenhando sua missão com mais coerência e sinergia. O seu papel, enquanto órgão de promoção internacional é correto e, infelizmente, demorou a ser compreendido.

Evidente que a criação do MTur, a ocupação de cargos estratégicos por profissionais do segmento e integrados tecnicamente, já que o quadro técnico da instituição foi esvaziado e desprezado durante as últimas duas décadas, devido aos demandos políticos, vem dificultando a sobrevivência, sustentabilidade e funcionamento da instituição. 
A elaboração e a execução de um plano com a devida monitorização de resultados (como o Plano Aquarela - aqui se faz a observação que não foi o primeiro, mas o único com continuidade) contribuíram muito.

Mas o desenvolvimento do Turismo brasileiro não se prendeu a EMBRATUR e suas fases de instabilidade, tão somente. Há de se considerar que ao longo dos últimos 10 anos, as instituições/entidades de classe foram se estruturando e se organizando melhor, houve um processo de descentralização natural da gestão do Turismo, novas organizações atuando no setor com ênfase na profissionalização e qualificação, enfim não se atribui mais ao governo toda a responsabilidade no que tange a execução e o investimento para o setor. A tendência de descentralização é que tem contribuído para o desenvolvimento do Turismo de forma definitiva em nosso país, mas por outro lado, essas mesmas instituições/entidades de classe que poderiam cobrar e exigir políticas consistentes, planejamentos e ações eficazes ou a sua continuidade são insuficientes para fazer frente aos interesses políticos.

O Sr. João Dória Jr. lembra que: "não basta apenas uma boa gestão do Ministério do Turismo ou da própria EMBRATUR. É preciso haver uma política de Turismo mais séria, estruturada, sobretudo abraçada pelo poder público, sustentada e interligada em vários ministérios e órgãos governamentais federais, estaduais e municipais. Não se faz Turismo apenas com o suporte institucional de um Ministério ou de um órgão e nem mesmo se faz uma política de Turismo apenas com investimento em marketing e promoções. É preciso mais do que isso".

De acordo com Flávio Coelho - ex-presidente da EMBRATUR 1994/1995, "No Brasil precisa-se ainda fazer com que os políticos não se esqueçam dos compromissos que assumem com o Turismo durante as campanhas eleitorais".

O Sr. Caio Luiz de Carvalho argumenta que "Ainda há muito a ser feito, mas a evolução foi grande. No entanto, é fundamental, ainda, o investimento no sistema aéreo e na criação de vôos que aproximem o Brasil internamente e dos destinos no Exterior, além do estimulo aos vôos charteres e à aviação 
regional. Enquanto isso não for feito, o trabalho, apesar de intenso, poderá não ser aproveitado e desenvolvido em sua totalidade, já que não haverá vôos para atender a oferta e a demanda gerada pelo desenvolvimento da atividade e pelo amadurecimento do brasileiro com turista e do interesse do estrangeiro no Brasil.

É importante observar que concordamos com a opinião dos servidores entrevistados que em geral, são céticos quanto a fazer uma projeção para o futuro da instituição, pois o vêem como uma incógnita. No entanto, afirmam que embora a instituição não tenha melhorado seus projetos significativamente do ponto de vista dos benefícios aos servidores, seus projetos, planos e metas evoluíram bastante. 


\section{7 - CONSIDERAÇÕES FINAIS}

Esta pesquisa buscou apresentar as ações e as principais contribuições da EMBRATUR para o desenvolvimento do Turismo no Brasil, não somente como um órgão gestor do Turismo nacional, mas como propulsor do desenvolvimento do Turismo em nosso país. Além disso, mapeou a sua trajetória, mostrando o desenvolvimento do Turismo nos últimos quarenta anos, analisando a sua representatividade para o Turismo.

A pesquisa foi realizada, por meio de analise documental e da coleta de informações, através de questionários aplicados a ex-presidentes, presidentes de entidades de Turismo, jornalistas, servidores e ex-servidores ativos e aposentados, conforme descrito na seção 3 e Apêndice I e II.

Pela pesquisa observou-se que houve um progresso desde a sua criação até os dias atuais. A EMBRATUR passou por vários momentos diferenciados ao longo desses 40 anos, alternando altos e baixos, sucessos e insucessos, erros e acertos. Evidentemente que essa instabilidade impactou em sua missão, enquanto órgão máximo do Turismo nacional, quando ainda nem se pensava na criação de um Ministério do Turismo.

A pesquisa revelou também a necessidade de uma continuidade de todas as ações e projetos que estão sendo desenvolvidos e comercializados para que o país possa alcançar um melhor posicionamento no "ranking" mundial de destino turístico.

Também como resultado da pesquisa, foi observado que a EMBRATUR esta dando especial atenção ao turismo cultural, que se torna um caminho para fortalecer, ampliar e divulgar uma nova imagem do país, por sua diversidade cultural e natural.

O Turismo segue a mesma linha do país, em termos de enfrentamento de todas as dificuldades políticas e sociais. O segmento turístico tem enfrentado grandes desafios, um deles é o alcance de um patamar de estabilidade e o seu posicionamento frente ao mercado turístico nacional e 
internacional. Cabendo a EMBRATUR criar ações que possam ser um diferencial para que o país vença esses desafios.

A consulta aos documentos da EMBRATUR, noticiário da imprensa e os depoimentos colhidos junto aos respondentes dos questionários permitiram concluir que as ações da EMBRATUR de maior impacto, no período de 1966 a 2006 foram:

\section{Área de ordenação/regulamentação:}

Responsável pela elaboração das diretrizes que nortearam o Turismo brasileiro. Foi importante porque orientou os empresários quanto ao desenvolvimento dessas diretrizes e contribuiu para o ordenamento do Turismo Nacional, como exemplo a regulamentação das Agências de Viagens, Hotéis e Transportes turísticos.

\section{Área de Financiamento}

Área criada para incrementar o desenvolvimento da atividade turística, ordenar e ampliar os recursos que a união disponibilizava ao setor privado, incentivando o empresariado a investir nesta atividade. Foi importante porque concedeu incentivos de ordem fiscal e financeira, por meio de Fundos de Incentivos tais como: FUNGETUR, FISET e PRODETUR que contribuíram para o desenvolvimento de regiões pouco exploradas e para melhoria do parque hoteleiro, deficitário, mas cujo potencial era ilimitado. Mais recentemente, o PRODETUR apoiou a infra-estrutura do Nordeste.

\section{Área de Marketing}

As ações desenvolvidas pela Área de Marketing têm como foco principal os turistas e os profissionais nacionais e internacionais. É também, responsável pelo planejamento e execução da política de marketing, promoção, 
propaganda e relações públicas do Turismo brasileiro no exterior, além de oferecer suporte às demais diretorias da EMBRATUR (EMBRATUR, 2006, P.126).

Por de tratar de um estudo exploratório, suas conclusões não se prestam a generalizações.

Como sugestão de pesquisas futuras que podem ajudar a alcançar um melhor entendimento da atuação da EMBRATUR e da configuração do Turismo no Brasil, sugere-se como temas:

- As cadeias internacionais teriam se estabelecidos no Brasil, mesmo sem os incentivos fiscais?

- Qual seria a composição ideal de parcerias no marketing, em termos de aportes financeiros?

- Observou-se um momento inicial de rigorosa regulamentação das Agencias de Viagens, seguida da liberalização, em 1986. Qual seria o nível ideal de regulamentação?

A pesquisa apresentou depoimentos de vários gestores da EMBRATUR, durante o período que vai de sua criação até os dias de hoje. Há um certo consenso entre eles de que pelo patrimônio turístico que o Brasil possui, a atividade poderia apresentar um desenvolvimento maior do que possui, tanto em termos de geração de empregos, quanto de renda.

Para alcançar um patamar compatível com seu potencial, caberia um aumento substancial dos recursos investidos em marketing, diversificando as ações e os países atingidos. O Turismo é uma das atividades econômicas que geram maior volume de renda no mundo, por isso mesmo é um mercado extremamente competitivo. Não há, portanto, como incrementar, consideravelmente, o fluxo turístico receptivo sem um investimento em marketing, à altura. 


\section{REFERENCIAL BIBLIOGRÁFICO}

ACERENZA, Miguel Angel. Promoção Turística. Um Enfoque Metodológico. São Paulo: Pioneira, 1991.

ANDRADE, José Vicente de. "Turismo: Fundamentos e Dimensões". São Paulo. Ática, 1992.

BARBETTA, P. A. Estatística Aplicada as Ciências Sociais. Florianópolis: ed. da UFSC, 2001.

BARRETO, Margarita. Manual de Iniciação ao Estudo do Turismo. 7 ed. Campinas, SP: Casa do Psicologo, 1999.

BARRETO, Margarita. Planejamento e organização em Turismo. Campinas: Papirus, 1991.

BENI, Mário Carlos. Análise estrutural do Turismo. 6ª ed. atual. São Paulo: Editora Senac São Paulo, 2001.

BENI, Mário Carlos. Política e planejamento do turismo no Brasil. São Paulo: Aleph, 2006.

BOLETIM INTERNO DA EMBRATUR. Rio de Janeiro, 1988.

BRASIL, Ministério do Turismo. Turismo social: diálogos do Turismo: uma viagem de inclusão. Rio de Janeiro: IBAM, 2006. 
CASTELLI, Geraldo. Turismo, atividade marcante do século XX. Caxias do Sul: Educs, 2001.

CERVO, Al e BERVIAN, Pa. Metodologia cientifica. São Paulo: McGraw Hill do Brasil, 1978.

DENCKER, Ada F. M. Métodos e técnicas de pesquisa em Turismo. $7^{a}$ edição. São Paulo: Futura, 1998.

DIAS, Reinaldo. Planejamento do Turismo - Política e Desenvolvimento do Turismo no Brasil. Atualizada com o Plano Nacional de Turismo. Editora Atlas. São Paulo, 2003.

FILHO, João dos Santos. EMBRATUR, da euforia ao esquecimento: o retorno às raízes quando serviu à Ditadura Militar. Disponível em: http://www.espacoacademico.com.br/035/35jsf.htm. Acesso em 18 de jan. 2007.

HALL, Colin Michael. Planejamento turístico: políticas, processos e relacionamentos. São Paulo: Contexto, 2001.

IGNARRA, Luiz Renato. Fundamentos do Turismo. 2 ed. São Paulo: Pioneira Thomson Learning, 2003.

IGNARRA, Luiz Renato. Fundamentos do Turismo. São Paulo: Pioneira, 1999.

KOTLER, Philip, Marketing (Ed. Compacta)- $3^{a}$ Edição. São Paulo, Atlas, 1985. 
KOTLER, Philip. Administração de Marketing: análise, planejamento, implementação e controle. São Paulo: Atlas, 1994.

KOTLER, Philip; HAIDER, Donald H; REIN, Irving. Marketing público: como atrair investimentos, empresas e Turismo para cidades, regiões, estados e países. São Paulo: Makron Books, 1994.

LAGE, Beatriz Helena Gelas; MILONE, Paulo César. Fundamentos econômicos do Turismo in: LAGE, Beatriz Helena Gelas; MILONE, Paulo César (Org.). Turismo: Teoria e prática. São Paulo: Atlas, 2000.

LEITE, Rogério C. de Cerqueira, 1999. Caderno Turismo, jornal Folha de São Paulo, 21/02/1991.

MINISTÉRIO DO TURISMO. Plano Nacional do Turismo - Diretrizes, Metas e Programas. Brasília, 2003.

MINISTÉRIO DO TURISMO. Turismo no Brasil 2007/2010. Brasília, 2006.

MINISTÉRIO DO TURISMO/INSTITUTO BRASILEIRO DE TURISMO EMBRATUR. Plano Aquarela - Marketing Turístico Internacional do Brasil. Metodologia e Coordenação Chias Marketing. Brasília, 2005.

OLIVEIRA, Antônio Pereira. Turismo e Desenvolvimento - Planejamento e Organização. 3.ed., São Paulo: Atlas, 2001.

PINTO, Clara Oliveira. Escritórios Brasileiros de Turismo no Exterior: A Otimização do Projeto e das Ações por meio do Plano de Marketing. Instituto de Educação Superior de Brasília - IESB, Brasília, 2007. 
PIRES, Mario Jorge. Raízes do Turismo no Brasil. Baueri: Manole, 2001.

RUSCHMANN, Doris. Marketing Turístico: um enfoque promocional. 8. ed. São Paulo: Papirus, 2003.

SEGMENTAÇÃO DO TURISMO: MARCOS CONCEITUAIS: Introdução. Rio de Janeiro: 2006.

SCHERER, Luciana. Rede de Política Pública de Turismo no Rio Grande do Sul: Plano de Desenvolvimento Turístico "Viajando pelo Rio Grande". Dissertação (Mestrado em Ciências Sociais) - PURCRS, Porto Alegre, RS, 2005.

TRIGO, Luiz Gonzaga Godoi. Cronologia do Turismo no Brasil. São Paulo. Consórcio CTI/Terra - Editoração, 1991.

TRIGUEIRO, Carlos Meira. Marketing \& Turismo: como planejar e administrar o marketing turístico para uma localidade. Rio de Janeiro: Qualiymark, 1999.

VAZ, Gio Nuno. Marketing Turístico: receptivo e emissivo: um roteiro estratégico para projetos mercadológicos públicos e privados. São Paulo: Pioneira, 1999.

World Travel \& Tourism Concil - WTTC. Blueprint for new tourism. Disponível em: http:www.wttc.org/frameset.1.htm. Acesso em: 26 dez 2006. 
WAHAB, S. A. Introdução à administração do turismo. Alguns aspectos estruturais e operacionais do turismo internacional: teoria e prática. 3. ed. São Paulo: Pioneira, 1991. 


\section{APÊNDICES}




\section{APÊNDICE I \\ MODELO DE CORRESPONDÊNCIA E QUESTIONÁRIOS APLICADOS}

Este Apêndice apresenta o modelo da correspondência enviada e os questionários aplicados para levantamento das informações. A correspondência e os questionários foram enviados via e-mail, aos ex-presidentes (questionário 1) aos presidentes de entidades de Turismo, jornalistas de Turismo, servidores e ex-servidores da EMBRATUR ativos e aposentados (questionário 2).

\section{Correspondência}

Brasília, __/2007

Prezado Senhor,

Temos a satisfação de nos dirigir a V.Sas. para solicitar o preenchimento das questões formuladas a seguir em forma de questionário. Trata-se do levantamento de informações para subsidiar uma pesquisa que está sendo elaborada junto ao Centro de Excelência em Turismo da Universidade de Brasília, visando a elaboração de uma monografia de Pós-Graduação em Gestão de Negócios em Turismo.

Desde já agradeço a atenção em responder o questionário e aproveito para me colocar à disposição para qualquer informação necessária.

Atenciosamente,

Waldinéia Brasil 


\section{Questionário 1}

Questionário elaborado e aplicado junto aos ex Presidentes

1. Quais foram os principais projetos desenvolvidos pela EMBRATUR durante sua gestão?

2. Quais foram os principais desafios ou obstáculos enfrentados em face à conjuntura político-econômica brasileira e mundial à época?

3. Como se estruturava a EMBRATUR durante sua gestão em termos de recursos humanos disponíveis, escritórios pelo Brasil e, porventura, pelo mundo, divisão de tarefas e das metas almejadas à época?

4. Qual era o panorama do Turismo brasileiro e mundial durante sua gestão?

5. Como vê a constante e crescente profissionalização da atividade turística e sua relevância como atividade econômica?

6. Por favor, faça comentários que julgue pertinente a respeito do trabalho desenvolvido pela EMBRATUR durante sua gestão. 


\section{Questionário 2}

O questionário 2 foi elaborado para ser aplicado junto aos presidentes das Entidades de Turismo, Jornalista de Turismo, Servidores e Ex-servidores (ativos e aposentados) da EMBRATUR.

\section{Presidentes de Entidades de Turismo:}

1. A EMBRATUR nos seus 40 anos cumpriu seu papel no desenvolvimento do Turismo brasileiro?

2. Como o Senhor, empresário do setor, vê a EMBRATUR nos próximos anos?

\section{Jornalistas de Turismo:}

1. A EMBRATUR nos seus 40 anos cumpriu seu papel no desenvolvimento do Turismo brasileiro?

2. Como o Senhor, jornalista de Turismo vê a EMBRATUR nos próximos anos?

Servidores (ativos e aposentados) da EMBRATUR:

1. A EMBRATUR nos seus 40 anos cumpriu seu papel no desenvolvimento do Turismo brasileiro?

2. Como você, servidor da casa, vê a EMBRATUR nos próximos anos?

\section{Ex-servidores (ativos e aposentados) da EMBRATUR:}

1. A EMBRATUR nos seus 40 anos cumpriu seu papel no desenvolvimento do Turismo brasileiro?

2. Como você, ex-servidor da casa, vê a EMBRATUR nos próximos anos? 


\section{APÊNDICE II}

\section{QUEM AJUDOU A FAZER A HISTÓRIA DA EMBRATUR}

Este Apêndice apresenta uma síntese biográfica dos ex-dirigentes que ajudaram a fazer a história da EMBRATUR.

Foram dezesseis os funcionários, hoje já aposentados, sendo um já falecido, que se estivessem na ativa, estariam também completando 40 anos de serviço em prol do Turismo, juntamente com a empresa. Eles deram relevantes contribuições para a evolução da empresa, trabalhando pelo desenvolvimento do Turismo brasileiro, consequentemente ajudando a fazer a história da EMBRATUR. Eles são:

- GERSON ANTONIO FONSECA - Procurador, nascido em São Paulo (SP), funcionário $n^{\circ}$. 1, foi encarregado pelo Setor Administração Geral da Assessoria Jurídica da EMBRATUR (1969), colocado à disposição do Conselho Nacional do Turismo (CNTur), de 1970 a 1976, Assessor da Diretoria de Investimentos, Chefe da Assistência Jurídica da Diretoria de Investimentos e, em 1980, re-lotado na Assessoria Jurídica da presidência da EMBRATUR.

- EUZÉBIO DE ALMEIDA RIBEIRO - motorista dos presidentes da EMBRATUR, desde que entrou na empresa, 1967. Sergipano, seu Ribeiro, como era conhecido, serviu à aproximadamente 7 (sete) presidentes da casa.

- ALDA FERNANDES PESSOA - Ingressou na EMBRATUR em 1967, como secretária. Sua função era atuar nas reuniões da diretoria da empresa, àquela época formada por um colegiado. Antes de aposentar-se estava lotada na SEGAB.

- MARIA APARECIDA TENAN - Também lotada na Secretaria da Presidência, Maria Aparecida entrou na EMBRATUR como escriturária e, em seguida, organizou o setor de protocolo da empresa, onde trabalhou por sete anos. Na SEGAB, permaneceu desde a administração do presidente Said Farhat (1975 1979). Antes de aposentar-se ocupava cargo de técnico na empresa.

- SANDRA AMARAL - Foi admitida na EMBRATUR no cargo de escriturária. Em seguida foi promovida a secretária e passou a chefe do Setor de Registro, 
permanecendo em cargo de chefia, por mais de dez anos, até pedir exoneração. Antes de aposentar-se ocupava o cargo de Assessora da Diretoria de Operações da EMBRATUR.

- TARCISIO DINIZ SOBREIRA - Pernambuco, Tarcisio entrou na EMBRATUR, como contínuo da empresa. Rapidamente foi promovido a escriturário, depois a oficial de administração e, em seguida, a chefe de setor e a responsável pela Divisão de Gestão dos Fundos do FISET, ligada à Diretoria de Investimentos. Permaneceu durante dezesseis anos ocupando cargos de chefias na empresa.

- ARMINDA LOURDES DE AZEVEDO - Formada em Ciências Sociais, lotada no Departamento de Desenvolvimento de Recurso Humanos, Turismo Social e Animação Turística. Inicialmente trabalhando como datilógrafa, Arminda foi cedida para a secretaria-executiva do Conselho Nacional de Turismo (CNTur), onde atuou de 1967 a 1973. Foi assessora do Conselho de Desenvolvimento Industrial do Ministério da Indústria e do Comércio, onde permaneceu até 1980. De volta à EMBRATUR, passou a trabalhar no então Centro de Treinamento Turístico (CENTRETUR).

- VAN PEREIRA FERNANDES - Economista, Ivan chegou a EMBRATUR, como almoxarife e dois anos depois era promovido ao cargo de chefe do Setor de Serviços Gerais. Após concluir o curso de Economia, em 1973, Ivan foi transferido, no ano seguinte, para a Diretoria de Assuntos Econômicos, mais tarde transformada em Diretoria de Investimentos, onde permaneceu até aposentar-se.

- ENEIDA DE CASTRO S. TORRES - Começou como secretária até 1971, do diretor de Assuntos Turísticos, se afastou da empresa em 75. Quando retornou ocupou o cargo de Chefe do Setor de Compras, e se aposentou lotada no setor de Apoio Administrativo da Diretoria de Operações.

- SERGIO DONATO FILIPELLI - Ingressou na EMBRATUR aos 14 anos como contínuo, trabalhou como datilógrafo, Chefe do Grupo de Comunicação e Arquivo (Protocolo). Exerceu a Chefia do Setor de Serviços Gerais, de 1978 a 1981, quando se transferiu para a Assessoria de Organização e Orçamento, lá permaneceu até transferir-se para a Coordenadoria de Marketing, como chefe de Divisão de Mala Direta e pouco depois para a Diretoria de Investimentos, como técnico na Assistência Técnica da DIRIN. 
- LACY SALGADO LAMEIRINHAS FONSECA - Começou como secretaria do Superintendente da empresa. Em 1969 foi requisitada para a Secretaria-Geral do Ministério da Indústria e do Comércio, só retornando à EMBRATUR em 1972. No ano seguinte, transferiu-se para o Conselho Nacional de Turismo e até 1980, exerceu ainda funções de redatora da EMBRATUR, secretaria da Diretoria de Investimentos e assessora da Assessoria Jurídica. Ao aposentarse esta lotada na Diretoria de Operações, na Divisão de Registro de Empresas.

- REINALdo MONTALVÃo NUNES - Foi o mais antigo técnico da empresa, quando estava na ativa, ingressado já como advogado e tendo como sua primeira missão a organização do Departamento Jurídico. De 1968 a 1970 foi assessor da Presidência. Em seguida exerceu os cargos de Assessor de Segurança e Informações (70-73), Chefe do Setor de Patrimônio Turístico, Consultor da Presidência, Superintendente e Chefe do Departamento de Implantação de Projetos da Diretoria de Operações, titular da Diretoria de Operações, dirigiu a Assessoria Técnica da Presidência, foi Diretor de Planejamento, além de ter participado, como representante da EMBRATUR, de diversos encontros nacionais e internacionais, e ministrou vários cursos sobre Turismo.

- PAULO dIAS PIZÃO - Ingressou na EMBRATUR como secretário, desempenhou funções Diretor de Investimentos, Assessor, Consultor Técnico, Assistente Executivo, Chefe de todos os Departamentos da área de Investimentos e uma atuação decisiva na estruturação, normatização e evolução dos investimentos do setor turístico no País. Pizão, como é conhecido na Empresa, começou como secretário, integrando a então Diretoria de Assuntos Econômicos, responsável pela elaboração inicial de todos os sistemas e parâmetros de avaliação e definição de investimentos do setor turístico. Advogado e administrador, Pizão representou a EMBRATUR nos conselhos técnicos e nas tarefas de planejamento e produção de normas, como a Lei de Estimulo ao Turismo, que foi apresentada ao congresso pelo então presidente da EMBRATUR, deputado Mac Dowell Leite de Castro.

- THEREZINHA DA CONCEIÇÃO MACEDO - Desde que iniciou seu trabalho na EMBRATUR, Therezinha esteve lotada na Diretoria de Operações, na qual ingressou como datilógrafa e passou, em seguida, para o cargo de secretária. Ocupou também o cargo de Chefia do Setor de Apoio da Diretoria de Operações. 
- ANA MARIA GASPAR PICOZZI - Entrou na EMBRATUR com recepcionista, e dois meses depois era promovida a secretária. Antes de iniciar a sua carreira como advogada da empresa, em 1972, Ana Maria exerceu os cargos de responsável pelas compras da EMBRATUR e oficial de Administração. Como advogada, ela trabalhou no então Departamento Jurídico, Diretoria de Planejamento e na Superintendência. Foi requisitada pelo Conselho Nacional de Turismo (CNTur), no cargo de assessora jurídica.

- LUIZ AFFONSO D’ESCRAGNOlLe FILHO (falecido) - Requisitado do Ministério da Educação e Cultura para trabalhar na EMBRATUR, em 67, D’Escragnolle atuou como Chefe de Divisão de Ordenação de Território, órgão da Diretoria de Planejamento. Arquiteto com vários trabalhos no exterior, ocupou os cargos de Encarregado do Setor de Divisão de Estudos e Aplicação de Recursos, Encarregado do Setor de Análise Física, Consultor da Diretoria, Superintendente de Projetos Especiais e Coordenador de Projetos Especiais. 
ANEXOS 
ANEXO I

Leis e Decretos-Leis

Criação e transformação da EMBRATUR 


\section{Presidência da República \\ Casa Civil \\ Subchefia para Assuntos Juriclicos}

DECRETO-LEI N 55, DE 18 DE NOVEMBRO DE 1966.

Revogado pela Lei $n^{\circ} 8.181$, de 1991

Define a politica nacional de turismo. cria o Conselho Nacional de Turismo e a Emprêsa Brasileira de Turismo, e dá outras providèncias.

O PRESIDENTE DA REPÚBLICA, usando da atribuiçăo que the confere o artigo $2^{\circ}$ do Ato Complementar número 23 , de 20 de outubro de 1966.

DECRETA:

\section{CAPITULO i}

Da Politica Nacional de Turismo

Art. $1^{\circ}$ Compreende-se como política nacional de turismo a atividade decorrente de tôdas as iniciativas ligadas à indústria do turismo sejam originárias de setor privado ou público, isoladas ou coordenadas entre si. desde que reconhecido seu interêsse para o desenvolvimento econômico do país.

Art. $2^{\circ}$ As atribuições do Govêrno Federal na coordenaçăo e no estimulo às atividades turisticas no território nacional serăo exercidas na forma dêste Decreto-lei e das normas que surgirem em sua decorrência.

$\S 1^{\circ} \mathrm{O}$ Govêrno Federal orientará a política nacional de turismo, coordenando as iniciativas que se propuserem a dinamizá-lo, para adaptá-la às reais necessidades de desenvolvimento econômico e cultural;

$\S 2^{\circ}$ O Govêrno Federal, através dos órgãos criados neste Decreto-lei, coordenará todos os programas oficiais com os da iniciativa privada, garantindo um desenvolvimento uniforme e orgânico à atividade turistica nacional.

Art. $3^{\circ} \mathrm{O}$ Poder Público atuará, através de financiamentos e incentivos fiscais, no sentido de canalizar para as diferentes regiőes turisticas do $P$ ais as iniciativas que tragam condiçőes favoráveis ao desenvolvimento dêsse empreendimento.

\section{CAPITULOII}

\section{Do Conselho Nacional de Turismo}

Art. $4^{\circ} \dot{E}$ criado o Conselho Nacional de Turismo, tendo como atribuições formular, coordenar e dirigir a política nacional de turismo.

Art. $5^{\circ} \mathrm{O}$ Conselho Nacional de Turismo, presidido pelo Ministro da Indústria e do Comércio, constituido de delegados de órgãos federais e representantes de iniciativa privada, terá composiçảo:

- Presidente da Emprêsa Brasileira de Turismo:

- Delegado do Ministério das Relaçöes Exteriores:

- Delegado do Ministério da Viaçăo e Obras Públicas:

- Delegado do Ministério da Aeronáutica; e

- Delegado da Diretoria do Patrimônio Histórico e Artistico Nacional;

- Representante dos Agentes de Viagens: 
- Representante dos Transportadores:

- Representante da Indústria Hoteleira.

$\S 1^{\circ} \mathrm{Em}$ suas faitas ou impedimentos o Ministro da Indústria e do Comércio, na sua qualidade de Presidente do Conselho, será substituído pelo Presidente da Emprêsa Brasileira de Turismo.

$\S 2^{\circ}$ Os representantes da iniciativa privada, terăo um mandato de 3 (três) anos e serăo escolhidos e designados pelo Ministro da Indústria e do Comércio, entre os nomes constantes de listas triplices. apresentadas pelos agentes de viagens, transportadores e indústria hoteleira, devendo serem escolhidos no mesmo ato, os respectivos suplentes.

Art. $6^{\circ}$ Compete ao Conselho Nacional de Turismo:

a) formular as diretrizes básicas a serem obedecidas na política nacional de turismo.

b) participar de entidades internacionais de turismo;

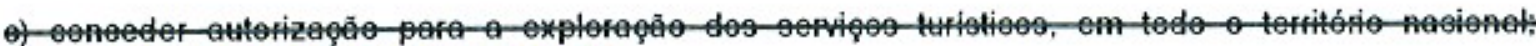
(Revogado pelo Decreto-lei $n^{\circ} 2.294$, de 1986)

d) expedir normas de disciplina e fiscalizaçăo das operaçōes da EMBRATUR das sançōes decorrentes do não cumprimento das obrigaçōes contraídas pelos mutuários;

e) baixar resoluçöes, atos ou instruçỏes regulamentares deste Decreto-lei, inclusive as que forem necessárias ao pleno exercicio de suas funçőes;

f) examinar, julgar e aprovar as contas que lhe forem apresentadas referentes aos planos de programas de trabalho executados;

g) aprovar o Plano Geral de Aplicaçäo dos recursos da EMBRATUR e homologar os contratos e convênios realizados pela aludida emprêsa;

h) modificar, suspender ou suprimir exigências administrativas ou regulamentares com a finalidade de facilitar e estimular as atividades de turismo, baixando as normas necessárias:

i) opinar na esfera do Poder Executivo ou quando consultado por qualquer das Casas do Congresso Nacional sôbre anteprojeto e projetos de lei que se relacionem com o turismo ou adotem medidas que neste possam ter implicaçőes;

j) aprovar o projeto dos Estatutos da Emprêsa Brasileira de Turismo (EMBRATUR) e suas eventuais alteraçỏes, submetendo-as à aprovação do Presidente da República, mediante decreto:

k) aprovar o aumento de capital da Emprêsa Brasileira de Turismo, sempre que necessário:

I) aprovar planos de financiamento e convênios com instituiçōes financeiras e autarquias bancárias autônomas, depois de ouvido o Conselho Monetário Nacional ou o Banco Central da República do Brasil;

m) organizar o seu regimento interno.

Art. $7^{\circ}$ Compete ao Presidente do Conselho:

a) presidir as reuniōes do Conselho;

b) designar os membros do Conselho Fiscal da Emprêsa de Turismo (EMBRATUR) e os respectivos suplentes;

c) vetar as decisǒes do Conselho nos casos do artigo $9^{\circ}$ deste Decreto-lei e recorrer "ex-offício" de sua decisảo para o Presidente da República; 
d) representar o Conselho nas suas relaçőes com terceiros:

e) promover a execução das decisões do Conselho.

Art. $8^{\circ} \mathrm{O}$ Conselho Nacional de Turismo utilizará, mediante delegação, os serviços das representaçð̋es diplomáticas, económicas e culturais do Brasil, no exterior, para tarefas de divulgação e informação turistica nacionais, bem como para prestação de assistência turística aos que dela necessitarem.

Art. $9^{\circ}$ As decisões do Conselho Nacional de Turismo, ainda que normativas, poderão ser vetadas pelo seu Presidente, sempre que a seu critério, sejam contrárias à Politica Nacional do Turismo, recorrendo "exofficio" de sua decisảo para o Presidente da República.

Art. 10. Os membros integrantes do Conselho Nacional do Turismo terăo direito a uma gratificaçăo por Sessăo a que comparecerem, fixada mediante decreto do Poder Executivo.

\section{CAPITULO III \\ Da Emprêsa Brasileira de Turismo}

Art. 11. É criada a Empêsa Brasileira de Turismo (EMBRATUR) vinculada ao Ministério da Indústria e do Comércio, com a natureza de Emprẻsa Pública e a finalidade de incrementar o desenvolvimento da indústria de Turismo e executar no âmbito nacional as diretrizes que thes forem traçadas pelo Govêrno. (Vide Lei $n^{\circ}$ 8.181, de 1991)

$\S 1^{\circ}$ A EMBRATUR terá personalidade juridica de direito público, patrimônio próprio e autonomia administrativa e financeira.

$\S 2^{\circ}$ A sede da EMBRATUR será na cidade do Rio de Janeiro, Estado da Guanabara, até que o poder Executivo a fixe em definitivo em Brasília.

Art. 12. A Emprêsa Brasileira de Turismo (EMBRATUR) terá o capital de Cr $\$ 50.000 .000 .000$ (cinqüenta bilhōes de cruzeiros) constituido integralmente pela Uniāo, mediante as dotaçōes orçamentárias ou créditos especiais e será integralizado até o exercicio financeiro de 1971, da seguinte forma:

a) $\mathrm{Cr} \$ 10.000 .000 .000$ (dez bilhőes de cruzeiros) no exercício financeiro de 1967;

b) os restantes $\mathrm{Cr} \$ 40.000 .000 .000$ (quarenta bilhōes de cruzeiros) em parcelas anuais de $\mathrm{Cr} \$$ 10.000 .000 .000 (dez bilhỏes de cruzeiros) que serão consignados no orçamento da Uniăo nos exercicios financeiros de 1968 a 1971.

$\S 1^{\circ} \mathrm{O}$ capital de que trata êste artigo, uma vez integralizado, poderá ser aumentado, na proporção da receita que Ihe fôr deferida pela União mediante cotaçőes especificas ou reavaliação de ativo e incorporaçăo de reservas.

$\S 2^{\circ} \mathrm{O}$ aumento de capital referido no parágrafo anterior, será realizado pela Empre̊sa Brasileira de Turismo, mediante prévia autorização do Conselho Nacional de Turismo.

Art. 13. Compete à Emprêsa Brasileira de Turismo (EMBRATUR):

a) fomentar e financiar diretamente as iniciativas, planos, programas e projetos que visem 0 desenvolvimento da indústria do turismo, na forma que fôr estabelecida na regulamentação dêste Decreto-lei ou com resoluçőes do Conselho Nacional do Turismo:

b) executar to̊das as decisỏes, atos, instruçỏes e resoluçōes expedidas pelo Conselho;

c) celebrar contratos, estudos e convénios, autorizados pelo Conselho, com entidades públicas e privadas, no interêsse da indústria nacionai de turismo e da coordenaçăo de suas atividades;

d) estudar de forma sistemática e permanente o mercado turistico, a fim de contar com os dados necessários para um adequado contrôle técnico; 
e) organizar, promover e divulgar as atividades ligadas ao turismo;

f) fazer o registro e fiscalização das emprêsas dedicadas à indústria de turismo, satisfeitas as condiçס̃es fixadas em normas próprias;

g) estudar e propor ao Conselho Nacional de Turismo os atos normativos necessários ao seu funcionamento;

h) movimentar os recursos da Empêsa dentro das diretrizes traçadas pelo Conselho, autorizando a realização de despesas e o respectivo pagamento, devendo êsses papéis serem firmados em conjunto pelo Presidente e um Diretor.

Art. 14. A administraçăo da Emprêsa Brasileira de Turismo será exercida por uma Diretoria e será constituida de um Presidente e dois Diretores, todos com mandato de quatro anos.

Art. 15. A remuneraçăo do Presidente e dos Diretores da EMBRATUR será fixada pelo Ministro da Indústria e do Comércio.

Art. 16. Além da Diretoria, a Emprêsa Brasileira de Turismo (EMBRATUR) terá um Conselho Fiscal composto de 3 (três) membros, e respectivos suplentes, designados pelo Presidente do Conselho Nacional de Turismo pelo prazo de 1 (um) ano.

Art. 17. As disposiçōes concernentes às atribuições da Diretoria do Conselho Fiscal e dos demais órgãos integrantes da Emprêsa Brasileira de Turismo (EMBRATUR) criados neste Decreto-lei, nêle não referidos ou que dêle resultem expressa ou implicitamente, serão defínidas nos respectivos Estatutos.

Parágrafo único. Os Estatutos da Emprêsa Brasileira de Turismo (EMBRATUR) serão aprovados pelo Conselho Nacional de Turismo e baixados mediante Decreto do Poder Executivo.

Art. 18. O Presidente e Diretores da EMBRATUR poderăo pertencer aos quadros da Administração centralizada ou descentralizada, caso em que deverăo optar entre a remuneraçăo do lugar de origem e a outra sem prejuizo dos direitos que lhes conferiu a legislaçăo, a que estiverem subordinados.

\section{CAPÍTULOIV}

Dos Recursos Financeiros

Art. 19. Além do capital a que se refere o artigo 12 dêste Decreto-lei, a EMBRATUR, poderá contar com os seguintes recursos:

a) da receita do sêlo de turismo, referido no artigo 20 ;

b) de créditos especiais e suplementares;

c) de contribuiçōes de qualquer natureza, sejam públicas ou privadas; natureza;

d) dos juros e amortizações dos financiamentos que realizar ou de operaçōes financeiras de qualquer

e) de outros recursos de qualquer natureza que Ihes sejam destinados.

Parágrafo único. Com os recursos dêste artigo poderá a EMBRATUR, ouvido prèviamente o Conselho Nacional de Turismo, constituir fundos especiais, desde que diretamente vinculados ao desenvolvimento do Turismo.

Art. 20. Fica criado o Sêlo do Turismo, que será editado em séries especiais pelo Departamento dos Correios e Telégrafos, com uma adicional de não menos de $20 \%$ e não mais de $35 \%$ destinados a integrar os recursos da EMBRATUR.

$\S 1^{\circ} \mathrm{A}$ Casa da Moeda fica autorizada, exclusivamente para o caso previsto neste artigo, a contratar com entidades privadas a impressão de sêlos. 
$\S 2^{\circ}$ Os sêlos de que trata êste artigo serão emitidos nos valores e quantidades determinadas pelo Departamento dos Correios e Telégrafos e terão seus temas e características técnicas e artísticas fixadas pela EMBRATUR.

Art. 21. As receitas procedentes de quaisquer fontes, bem como os demais recursos previstos, serão depositados no Banco do Brasil S.A., em conta especial em nome da Emprêsa Brasileira de Turismo, (EMBRATUR) que os movimentará na conformidade do que designar a regulamentaçăo dêste Decreto-tei.

Art. 22. Os recursos da EMBRATUR, atendidas as finalidades estabelecidas neste Decreto-lei e deduzido o que fôr necessário à sua manutençăo e funcionamento, serão por ela aplicados exclusivamente na concessão de financiamentos diretos às iniciativas, planos, programas e projetos que:

a) tenham reconhecidas a prioridade e viabilidade técnica e econômica, do ponto de vista da indústria do turismo.

b) tenham sido aprovados pelo Conselho Nacional de Turismo.

$\S 1^{\circ}$ Os pressupostos e as condições dos financiamentos a que se referem êste artigo, serăo objeto de regulamentação deste Decreto-lei e de Resoluções do Conselho Nacional de Turismo.

$\S 2^{\circ}$ As despesas administrativas da Emprêsa Brasileira de Turismo (EMBRATUR) não poderăo exceder a $25 \%$ (vinte e cinco por cento) do seu orçamento anual.

\section{CAPITULO $\mathrm{V}$ \\ Dos Incentivos Fiscais}

Art. 23. A construção, ampliação ou reforma de hotéis, obras e serviços específicos de finalidades turísticas constituindo atividades econômicas de interêsse nacional, desde que aprovadas pelo Conselho Nacional de Turismo, ficam equiparadas à instalaçăo e ampliaçăo de indústrias básicas e, assim, incluidas no item IV do artigo 25 da lei $n^{\circ} 2.973$, de 26 de novembro de 1956.

Art. 24. Os hotéis em construçăo e os que se construirem ou se ampliarem dentro dos próximos 5 (cinco) anos da data deste Decreto-lei, desde que seus projetos tenham sido ou venham a ser aprovados pelo Conselho Nacional de Turismo e tenham as obras terminadas dentro do prazo, gozarăo de isenção fiscal de todos os tributos federais, exceto os da Previdência Social, pelo prazo de 10 (dez) anos a partir da aceitação de suas obras pelo referido órgão.

Art. 25. As pessoas jurídicas poderăo pleitear o desconto de até $50 \%$ (cinquuenta por cento) do impôsto de renda e adicionais năo restituiveis que devam pagar, para investimento na construção, ampliação ou reforma de hotéis, e em obra e serviços específicos de finalidades turisticas, desde que tenham seus projetos aprovados pelo Conselho Nacional de Turismo, com parecer fundamentado da Emprêsa Brasileira de Turismo.

Art. 26. Até o exercício de 1971, inclusive, os hotéis de turismo, que estiverem operando à data da publicação dêste Decreto-lei, poderăo pagar com a ređução de até $50 \%$ (cinqüenta por cento) o impôsto de renda e os adicionais nåo restituiveis, desde que a outra parte venha a reverter em melhoria de suas condiçōes operacionais.

Parágrafo único. O Conselho Nacional de Turismo, mediante as cautelas que instituir, fornecerá às emprêsas interessadas, declaraçăo de que satisfizeram as condiçōes exigidas para o beneficio da reduçăo dêste e do artigo 25 , documento que instruirá o processo de recolhimento pela Divisăo de Impôsto de Renda, do direito da Emprêsa ao favor tributário.

Art. 27. Os estímulos fiscais previstos nos artigos 24, 25 e 26 não poderão ser concedidos cumulativamente com os de que tratam as Leis números 4.216, de 6 de maio de 1963 e 4.869 , de 1 de dezembro de 1965 , e Lei 5.174 de 27 de outubro de 1966.

Art. 28. A concessão de estímulos ou financiamentos por parte do Conselho Nacional de Turismo e de estabelecimentos oficiais de crédito sòmente será dada aos empreendimentos devidamente aprovados e localizados onde existam isençōes fiscais ou outras facilidades fiscais de estimulo ao turismo já concedidas pelo Estado e Municipio. 


\section{CAPITTULO VI \\ Disposições Gerais}

Art. 29. Os órgãos oficiais, estaduais e municipais deverăo submeter prèviamente ao Conselho Nacional de Turismo planos e calendários turisticos organizados para cada exercício, a fim de que sejam incluidos no plano turístico nacional.

Art. 30. A EMBRATUR deverá apresentar anualmente, até 90 (noventa) dias após o encerramento do exercicio, ao Conselho Nacional do Turismo, um relatório pormenorizado do qual constarăo, obrigatòriamente, demonstração estatística do movimento turístico externo e interno e balanço econômico das atividades turísticas, especialmente quanto aos seus efeitos sôbre o balanço internacional de pagamentos.

Art. 31. A EMBRATUR gozará de total imunidade de tributos federais extensivel aos contratos e convênios que celebrar com terceiros.

Art. 32. Fica criada no Departamento Nacional do Comércio, da Secretaria do Comércio, do Ministério da Indústria e do Comércio, a Divisão de Exposiçăo e Feiras (DEF), que terá suas atribuiçōes definidas pelo Poder Executivo.

Parágrafo único. É criado no Quadro de Pessoal do Ministério da Indústria e do Comércio, o cargo em comissăo, de Diretor da Divisăo de Exposição e Feiras, símbolo 4-C.

Art. 33. Os cargos da EMBRATUR sòmente poderão ser preenchidos mediante concurso público de provas e, subsidiàriamente, de títulos, salvo os de direção e os casos de contrataçăo, por prazo determinado, de profissionais especializados, nacionais ou estrangeiros.

$\S 1^{\circ}$ Compete ao Diretor-Presidente da EMBRATUR a admissão de empregados, segundo o Quadro aprovado pelo Conselho Nacional de Turismo, e demiti-los na forma que determinar o Regulamento.

$\S 2^{\circ} \mathrm{O}$ pessoal da EMBRATUR reger-se-á pela legislaçăo trabalhista e terá salários fixados com base nas condições do mercado de trabalho, revistos anualmente pelo Conselho Nacional de Turismo.

Art. 34. Fica extinta a Divisão de Turismo e Certames do Departamento Nacional do Comércio, da Secretaria do Comércio, do Ministério da Indústria e do Comércio, cujo acervo, documentação e atribuiç̋̃es constantes do Decreto número 56.303, de 20 de maio de 1965 e Decreto número 58.483, de 23 de maio de 1966 e Decreto número 58.756, de 28 de junho de 1966, passarão ao EMBRATUR na data de sua instalação, com exceçăo daquelas que dizem respeito a exposiçōes, feiras e certames.

Parágrafo único. Fica extinto, no Quadro de Pessoal do Ministério da Indústria e do Comércio, o cargo em comissão de Diretor da Divisão de Turismo e Certames, do Departamento Nacional do Comércio. símbolo 4-C.

Art. 35. Até que sejam organizados os seus serviços e o seu Quadro de Pessoal, o Presidente do Conselho Nacional do Turismo poderá requisitar para os seus serviços e da EMBRATUR os funcionários do serviço público federal, de Autarquias Federais e de Sociedades de Economia Mista, sem perda de vencimentos e vantagens permanentes relativos aos cargos que ocuparem.

Parágrafo único. Quando se tratar de funcionários requisitados para servir na EMBRATUR, deverão os mesmos, no prazo de 1 ano, contado da data da Regulamentação dêste Decreto-lei, fazer opçăo pelo regime de pessoal da EMBRATUR ou retornar ao órgão de origem.

Art. 36. Aos atuais funcionários civis da Uniāo, com exercicio na Divisão de Turismo e Certames, fica assegurado o direito de opção pelo regime de pessoal do parágrafo $2^{\circ}$ do artigo 33 dêste Decreto-lei ou pelo anterior "status".

$\S 1^{\circ} \mathrm{A}$ opção a que se refere êste artigo será feita no prazo de 1 ano a partir da data da regulamentaçăo dêste Decreto-lei, por intermédio dos órgåos de pessoal dos Ministérios a cujos quadros pertencerem.

$\S 2^{\circ}$ A transfere̊ncia para a EMBRATUR dos servidores de que trata êste artigo e o artigo 35 , determinará a vacância dos cargos nos quadros dos Ministérios a que pertencerem. 
$\S 3^{\circ}$ Aos funcionánios que optarem pelo regime de pessoal da EMBRATUR, será assegurada a contagem de tempo de serviço. para todos efeitos legais.

Art. 37. Enquanto não forem estabelecidas normas de atuaçăo da EMBRATUR, nos Estados, as atividades de turismo poderão ser delegadas, mediante convênio, às Delegacias Estaduais da Indústria e do Comércio.

Art. 38. O Poder Público poderá desapropriar áreas, desde que seja verificado o interêsse delas para o desenvolvimento das atividades turísticas.

Art. 39. A EMBRATUR poderá solicitar à Diretoria do Patrimônio Histórico e Artístico Nacional o tombamento dos bens móveis e imóveis, e dos bens a êsses equiparados, tais como monumentos naturais, sitios e paisagens, cuja proteção e conservação seja considerada de interêsse público.

Art. 40. É o Poder Executivo autorizado a abrir. no Ministério da Indústria e do Comércio, um crédito especial de $\mathrm{Cr} \$ 12.000 .000 .000$ (doze bilhöes de cruzeiros), a ser aplicado da seguinte forma:

1) Cr $\$ 10.000 .000 .000$ (dez bilhŏes de cruzeiros) para constituir os recursos de que trata a alínea a do artigo 12 dêste Decreto-lei;

2) $\mathrm{C}$ r 2.000 .000 .000 (dois bilhőes de cruzeiros) destinados a cobrir despesas de instalação, de manutençăo e de operaçőes da EMBRATUR e do Conselho Nacional de Turismo.

Art. 41. O crédito especial de que trata o artigo 40, terá vigência no exercício de 1967, e será automàticamente registrado no Tribunal de Contas e distribuido ao Tesouro Nacional.

Art. 42. As resoluções do Conselho Nacional de Turismo entram em vigor imediatamente e serăo publicadas no Diário Oficial da União.

Art. 43. No prazo de 120 (cento e vinte) dias da data da publicação dêste Decreto-lei, o Poder Executivo baixará a competente regulamentaçăo e tomará as medidas necessárias à instalação e funcionamento do Conselho Nacional de Turismo e da EMBRATUR.

Art. 44. Ėste Decreto-lei entrará em vigor na data de sua publicação, revogadas as disposições em contrário.

Brasilia, 18 de novembro de $1966 ; 145^{\circ}$ da Independência e $78^{\circ}$ da República.

\author{
H. CASTELLO Branco \\ Juracy Magaihães \\ Octavio Buthōes \\ Juarez Távora \\ Raymundo Moniz de Aragão \\ Eduardo Gomes \\ Paulo Egydio Martins \\ Roberto Campos
}

Este texto não substitui o publicado no D.O.U. de 21.11.1966 


\title{
Presidência da República \\ Casa Civil \\ Subchefia para Assuntos Jurídicos
}

LEI No 8.181, DE 28 DE MARÇO DE 1991.

Dá nova denominação à Empresa Brasileira de Turismo (Embratur), e dá outras providências.

\begin{abstract}
o PRESIDENTE DA REPÚBLICA, faço saber que o Congresso Nacional decreta e eu sanciono a seguinte Lei:

Art. $1^{\circ}$ A Empresa Brasileira de Turismo (Embratur), autarquia especial, criada nos termos do art. 11 do Decreto-Lei $n^{\circ}$ 55, de 18 de novembro de 1966, passa a denominar-se Embratur - Instituto Brasileiro de Turismo, vinculado à Secretaria de Desenvolvimento Regional da Presidência da República.
\end{abstract}

Parágrafo único. A Embratur tem sede e foro na Cidade de Brasilia. Distrito Federal.

Art. $2^{\circ}$ A Embratur tem por finalidade formular, coordenar, executar e fazer executar a Politica Nacional de Turismo. (Vide Medida Provisória n².216-37, de 2001)

\section{Art. $3^{\circ}$ Compete à Embratur:}

I - propor ao Governo Federal normas e medidas necessárias à execução da Politica Nacional de Turismo e executar as decisőes que, para esse fim, Ihe sejam recomendadas;

II - estimular as iniciativas públicas e privadas, tendentes a desenvolver o turismo interno e o do exterior para o Brasil;

III - promover e divulgar o turismo nacional, no País e no Exterior, de modo a ampliar o ingresso e a circulaçăo de fluxos turísticos, no território brasileiro;

IV - analisar o mercado turístico e planejar o seu desenvolvimento, definindo as áreas. empreendimentos e açōes prioritárias a serem estimuladas e incentivadas;

$V$ - fomentar e financiar, direta ou indiretamente, as iniciativas, planos, programas e projetos que visem ao desenvolvimento da indústria de turismo, controlando e coordenando a execuçăo de projetos considerados como de interesse para a indústria do turismo;

VI - estimular e fomentar a ampliaçăo, diversificação, reforma e melhoria da qualidade da infra-estrutura turistica nacional;

VII - definir critérios, analisar, aprovar e acompanhar os projetos de empreendimentos turísticos que sejam financiados ou incentivados pelo Estado:

VIII - inventariar, hierarquizar e ordenar o uso e a ocupaçăo de áreas e locais de interesse turístico e estimular o aproveitamento turístico dos recursos naturais e culturais que integram o patrimônio turístico, com vistas à sua preservação, de acordo com a Lei n ${ }^{\circ} 6.513$, de 20 de dezembro de 1977:

IX - estimular as iniciativas destinadas a preservar o ambiente natural e a fisionomia social e cultural dos locais turísticos e das populaçōes afetadas pelo seu desenvolvimento, em articulação com os demais órgãos e entidades competentes;

$X$ - cadastrar as empresas, classificar os empreendimentos dedicados às atividades turisticas e exercer função fiscalizadora, nos termos da legislação vigente; (Vide Decreto $n^{\circ} 4.898$, de 26.11.2003)

XI - promover, junto às autoridades competentes, os atos e medidas necessários ao desenvolvimento das atividades turísticas, à melhoria ou ao aperfeiçoamento dos serviços oferecidos aos turistas e à 
facilitação do deslocamento de pessoas no território nacional, com finalidade turistica:

XII - celebrar contratos, convênios, acordos e ajustes com organizaçőes e entidades públicas ou privadas nacionais, estrangeiras e internacionais, para a realização dos seus objetivos:

XIII - realizar serviços de consultoria e de promoçăo destinados ao fomento da atividade turistica;

XIV - patrocinar eventos turísticos:

XV-conceder prêmios e outros incentivos ao turismo:

XVI - participar de entidades nacionais e internacionais de turismo.

$\S 1^{\circ}$ Săo transferidos para a Embratur o acervo documental, as atribuiçőes e competências do extinto Conselho Nacional de Turismo (CNTur).

$\S 2^{\circ}$ A liberdade do exercício e a exploração de atividades e serviços turísticos, nos termos do DecretoLei $n^{\circ} 2.294$. de 21 de novembro de 1986. năo excluem a sua físcalizaçăo nem a obrigatoriedade de prestar as informaçőes necessárias à organização do cadastro a que se refere o inciso $X$ deste artigo.

$\S 3^{\circ}$ Os convênios celebrados com órgãos da Administraçăo Pública poderão dispor sobre a transferência de atribuições para o exercicio de atividades relacionadas às finalidades da Embratur, em especial as funções de fiscalização e arrecadação de suas receitas.

Art. $4^{\circ}$ A Embratur será administrada por um Presidente e três Diretores, nomeados, respectivamente, pelo Presidente da República e pelo Secretário do Desenvolvimento Regional e demissiveis ad nutum.

Art. $5^{\circ} \mathrm{O}$ provimento de cargos ou empregos do Quadro Permanente do Pessoal da Embratur será feito mediante concurso público de provas, ou de provas e títulos, ressalvadas as nomeaçōes para cargos ou funçōes de confiança, de livre nomeaçăo e exoneração.

$\S 1^{\circ}$ O Presidente da República, à vista de proposta do Secretário do Desenvolvimento Regional, poderá autorizar a contratação de profissionais especializados para atender necessidade temporária de excepcional interesse para os serviços da autarquia.

$\S 2 \circ$ A proposta do Secretário do Desenvolvimento Regional justificará a necessidade da contratação. indicará o número dos profissionais a serem contratados, os critérios de escolha, o prazo de duração dos contratos, que não será superior a doze meses, o montante das despesas e a disponibilidade de recursos.

Art. $6^{2}$ Constituem recursos da Embratur:

I - dotações que the forem consignadas no Orçamento da Uniảo;

II - receitas de qualquer natureza provenientes do exercicio de suas atividades;

III - rendas de bens patrimoniais ou o produto da sua alienação na forma da legislaçăo pertinente;

IV - empréstimos, auxilios, subvençōes, contribuiçōes, doaçỏes;

V - transferências de outros órgăos da Administração Pública Federal:

VI - resultados de aplicaçőes financeiras, na forma da legislaçăo pertinente:

VII - remuneração de serviços provenientes de financiamentos;

VIII - produto de multas decorrentes do exercicio da fiscalização:

IX - outras receitas eventuais. 
Art. $7^{\circ}$ Săo extensivos à Embratur os privilégios processuais da Fazenda Pública, em especial os relativos à cobrança dos seus créditos, custas, prazos, prescriçăo e decadência.

$\S 1^{\circ}$ As importâncias devidas à Embratur, a qualquer título, inclusive penalidades, não pagas nos prazos estabelecidos, serảo atualizadas na data do efetivo pagamento de acordo com o índice da variaçăo da Taxa Referencial Diária (TRD) e cobrados com os seguintes acréscimos:

a) juros de mora, na via administrativa ou judicial, contatos do mês seguinte ao do vencimento, à razăo de um por cento. calculados na forma da legislaçăo aplicável aos tributos federais:

b) multa de mora de vinte por cento, reduzida a dez por cento, se o pagamento for efetuado até o último dia útil do mês subseqüente àquele em que deveria ter sido feito;

c) encargo de vinte por cento, substitutivo da condenação do devedor em honorários de advogado, calculado sobre o total do débito inscrito como Divida Ativa, que será reduzido para dez por cento, se o pagamento for efetivado antes do ajuizamento da execução.

$\S 2^{\circ}$ Os juros de mora não incidem sobre o valor da multa de mora.

$\$ 3^{\circ}$ Os débitos com a Embratur, sem prejuizo da respectiva liquidez e certeza, poderăo ser inscritos em Divida Ativa pelo valor da Taxa Referencial Diária (TRD).

$\S 4^{\circ}$ Em casos excepcionais, observados os critérios fixados na legislação tributária, poderá o Presidente da Embratur autorizar o parcelamento de débitos. redaçăo:

Art. $8^{\circ} \mathrm{O}$ inciso 11 do art. $5^{\circ}$ da Lei $n^{\circ} 6.505$, de 13 de dezembro de 1977 , passa a vigorar com a seguinte

Art. $5^{\circ}$

II - multa de valor equivalente a até Cr\$391.369,57 (trezentos e noventa e um mil. trezentos e sessenta e nove cruzeiros e cinquienta e sete centavos); redação:

Art. $9^{\circ} \mathrm{O}$ inciso $\mathrm{I}$ do art. 24 da Lei $n^{\circ} 6.513$, de 20 de dezembro de 1977, passa a vigorar com a seguinte Art. 24

I - multa de valor equivalente a até Cr\$782.739.15 (setecentos e oitenta e dois mil. setecentos e trinta e nove cruzeiros e quinze centavos);

Art. 10. O caput do art. 16 do Decreto-Lei $n^{\circ} 1.439$, de 30 de dezembro de 1975. passa a vigorar com a seguinte redaçăo:

Art. 16. O funcionamento e as operaçōes do Fungetur observarăo os seguintes principios:

Art. 11. Os salários dos servidores da Embratur serão reajustados nas mesmas épocas e condiçŏes dos reajustamentos concedidos aos servidores públicos.

Art. 12. Os atuais Presidentes e Diretores da Empresa Brasileira de Turismo (Embratur) ficarăo investidos, na data da publicação desta lei, em iguais cargos da autarquia.

Art. 13. Fica ratificado o Fundo Geral de Turismo (Fungetur), criado pelo Decreto-Lei ${ }^{\circ} 1.191$, de 27 de outubro de 1971. nos termos do disposto no art. 36 do Ato das Disposições Constitucionais Transitórias. 
Art. 14. O Regimento Interno da Embratur, aprovado pelo Secretário do Desenvolvimento Regional, disporá sobre a organização e o funcionamento da Autarquia, bem como sobre a competência e as atribuiçőes do Presidente e dos Diretores e de suas substituiçð̌es nos casos de vacảncia, ausências ou impedimento.

Art. 15. Esta lei entra em vigor na data de sua publicaçăo.

Art. 16. Revogam-se o Decreto-Lei $n^{\circ} 55$, de 18 de novembro de 1966 . o $\$ 2^{\circ}$ do art. 11 do Decreto-Lei $n^{\circ} 1.191$, de 27 de outubro de $1971,0 \$ 2^{\circ}$ do art. $5^{\circ}$ e o art. $9^{\circ}$ da Lei $n^{\circ} 6.505$, de 13 de dezembro de 1977 o $\$ 2^{\circ}$ do art. 25 da Lei $n^{\circ} 6.513$, de 20 de dezembro de 1977 , o parágrafo único do art. $1^{\circ}$ do Decreto-Lei $n^{\circ}$ 2.294 , de 21 de novembro de 1986. e demais disposiçőes em contrário.

Brasilia, 28 de março de $1991 ; 170^{\circ}$ da Independência e $103^{\circ}$ da República

\section{FERNANDO COLLOR}

Jarbas Passarinho

Este texto não substitui o publicado no DOU de $1^{\circ} .4 .1991$ 


\section{Presidência da República \\ Casa Civil \\ Subchefia para Assuntos Jurídicos}

DECRETO N 4.672, DE 16 DE ABRIL DE 2003.

Revogado pelo Decreto $n^{\circ} 6.162$, de 2007

Aprova a Estrutura Regimental e o Quadro Demonstrativo dos Cargos em Comissão e das Funçōes Gratificadas da EMBRATUR - Instituto Brasileiro de Turismo, e dá outras providências.

o PRESIDENTE DA REPÚBLICA, no uso das atribuiçōes que the confere o art. 84, incisos IV e VI, alinea "a", da Constituiçăo, e tendo em vista disposto no art. 50 da Medida Provisónia $n^{2} 103$, de $1^{\circ}$ de janeiro de 2003 .

\section{DECRETA:}

Art. 12 Ficam aprovados, na forma dos Anexos I e II a este Decreto, a Estrutura Regimental e o Quadro Demonstrativo dos Cargos em Comissão e das Funçōes Gratificadas da EMBRATUR - Instituto Brasileiro de Turismo.

Art. $2^{2} \mathrm{Em}$ decorrência do disposto no art. ${ }^{2}$, ficam remanejados, na forma do Anexo III a este Decreto, os seguintes cargos em comissão do Grupo-Direçăo e Assessoramento Superiores - DAS:

I - da Secretaria de Gestão, do Ministério do Planejamento, Orçamento e Gestão para a EMBRATUR. um DAS 101.3; um DAS 102.4; e três DAS 102.3; e

II - da EMBRATUR para a Secretaria de Gestão, do Ministério do Planejamento, Orçamento e Gestão, quatro DAS 101.4; três DAS 101.2; dois DAS 101.1; dois DAS 102.2: dois DAS 102.1; onze FG-1; doze FG-2; e quatorze FG-3.

Art. $3^{2}$ Os apostilamentos decorrentes da aprovação da Estrutura Regimental de que trata o art. $1^{2}$ deverâo ocorrer no prazo de vinte dias, contado da data de publicaçăo deste Decreto.

Parágrafo único. Após os apostilamentos previstos no caput, o Presidente da EMBRATUR fará publicar no Diário Oficial da Uniåo, no prazo de trinta dias, contado da data de publicaçăo deste Decreto, relaçăo nominal dos titulares dos cargos em comissão do Grupo-Direção e Assessoramento Superiores - DAS a que se refere o Anexo II, indicando, inclusive, o número de cargos vagos, sua denominação e respectivo nivel.

Art. 42 O regimento interno da EMBRATUR será aprovado pelo Ministro de Estado do Turismo e publicado no Diário Oficial da União, no prazo de sessenta dias, contado da data de publicaçăo deste Decreto.

Art. 52 Este Decreto entra em vigor na data de sua publicaçăo.

Art. 62 Fica revogado o Decreto n².079, de 26 de novembro de 1996.

Brasilia, 16 de abril de 2003; 182 da Independência e 115² da República.

LUIZ INÁCIO LULA DA SILVA

Guido Mantega

Walfrido Silvino dos Mares Guia Neto

Este texto năo substitui o publicado no D.O.U. de 17.4.2003

ANEXO I 


\section{EMBRATUR - INSTITUTO BRASILEIRO DE TURISMO \\ CAPITULO I \\ DA NATUREZA, SEDE E FINALIDADE}

Art. 12 A EMBRATUR - Instituto Brasileiro de Turismo, autarquia especial, criada nos termos do art. 11 do Decreto-Lei n²5, de 18 de novembro de 1966, vinculada ao Ministério do Turismo, com sede e foro em Brasilia, Distrito Federal, e jurisdição em todo o território nacional.

Art. 2 A EMBRATUR tem por finalidade apoiar a formulaçăo e coordenar a implementação da Politica Nacional de Turismo, como fator de desenvolvimento social e econômico, cabendo-lhe, ainda, executar as açōes relativas:

I - à promoção e marketing de ofertas de destinos, produtos e serviços turísticos do Brasil nos mercados nacional e internacional;

II - ao incremento dos fluxos de turista nacionais e internacionais em suas várias modalidades;

III - às avaliaçőes de critérios, parâmetros e métodos para o controle e consolidação da base de dados gerenciais e estatísticos do turismo nacional; e

IV - ao implemento, controle e supervisão de ações para o incremento da qualidade e competitividade do turismo nacional.

\section{CAPITULO $\|$}

\section{DA ESTRUTURA ORGANIZACIONAL}

Art. 3 A EMBRATUR tem a seguinte estrutura organizacional:

I - órgãos de assistência direta e imediata ao Presidente:

a) Gabinete;

b) Assessoria de Comunicação Social; e

c) Procuradoria-Juridica;

II - órgãos seccionais:

a) Auditoria Interna; e

b) Departamento de Administraçăo e Finanças;

III - órgãos específicos singulares:

a) Departamento de Turismo de Lazer e Incentivos;

b) Departamento de Marketing e Relações Institucionais;

c) Departamento de Turismo de Negócios e Eventos; e

d) Departamento de Estudos e Pesquisas.

CAPITULO III 


\section{DA DIREÇÃO E NOMEAÇÃO}

Art. 4 A EMBRATUR é dirigida por um Presidente e cinco Diretores, indicados pelo Ministro de Estado do Turismo e nomeados pelo Presidente da República. da União.

$\S 1^{2}$ A nomeação do Procurador Jurídico deverá ser precedida da prévia anuência do Advogado-Geral

$\S 2^{2}$ A nomeaçăo do Auditor-Chefe será submetida pelo Presidente da EMBRATUR à aprovaçăo da Controladoria-Geral da Uniăo. vigente.

$\S 3^{2}$ Os demais cargos em comissão e funções gratificadas serão providos na forma da legislação

\section{CAPITULO IV}

\section{DAS COMPETENNCIAS}

\section{Seção I}

\section{Dos Órgåos de Assiste̊ncia Direta e Imediata ao Presidente}

Art. $5^{2}$ Ao Gabinete compete:

I - assistir ao Presidente da EMBRATUR em sua representaçăo politica e social e incumbir-se do preparo e despacho do seu expediente pessoal; e

II - exercer outras competências que the forem cometidas pelo Presidente da EMBRATUR.

Art. $6{ }^{2}$ A Assessoria de Comunicação Social compete assessorar o Presidente nos assuntos pertinentes a imprensa e a relações públicas. compete:

Art. 7ํ A Procuradoria-Juridica, na qualidade de órgão executor da Procuradoria-Geral Federal,

I - representar judicial e extrajudicialmente a EMBRATUR;

II - exercer atividades de consultoria e assessoramento juridicos aos órgåos da EMBRATUR, aplicandose, no que couber, o disposto no art. 11 da Lei Complementar nํ 73, de 10 de fevereiro de 1993;

III - fixar a interpretaçăo da Constituiçăo, das leis, dos tratados e dos demais atos normativos a ser uniformemente seguida em suas áreas de atuaçăo e coordenaçăo, quando não houver orientação normativa do Advogado-Geral da União;

IV - a apuração da liquidez e certeza dos créditos, de qualquer natureza, inerentes às atividades da EMBRATUR, inscrevendo-os em divida ativa, para fins de cobrança amigável ou judicial; e

V - examinar, prévia e conclusivamente, no âmbito da EMBRATUR:

a) os textos de editais de licitaçăo, bem como os dos respectivos contratos ou instrumentos congêneres, a serem publicados e celebrados;

b) os atos pelos quais se vá reconhecer a inexigibilidade ou decidir a dispensa de licitação;

c) propostas, estudos, projetos, anteprojetos e minutas de atos normativos de interesse da EMBRATUR; e judicial.

d) os processos e documentos que envolvam matérias referentes a assuntos de cunho administrativo ou 


\section{Dos Órgãos Seccionais}

Art. $8 \AA$ A Auditoria Interna compete examinar a conformidade legal dos atos de gestão orçamentáriofinanceiro, patrimonial, de pessoal, dos demais sistemas administrativos e operacionais, e especificamente:

I-verificar a regularidade nos controles internos e externos, especialmente daqueles referentes à realização da receita e da despesa, bem como da execução financeira de contratos, convênios, acordos e ajustes firmados pela EMBRATUR;

II - promover inspeçōes regulares para verificar a execução física e financeira dos programas, projetos e atividades e executar auditorias extraordinárias determinadas pelo Presidente;

III - examinar e emitir parecer sobre a prestaçăo de conta anual da entidade e tomadas de contas especiais; e

IV - propor açōes de forma a garantir a legalidade dos atos e o alcance dos resultados, contribuindo para a melhoria da gestăo.

Art. $9^{2}$ Ao Departamento de Administração e Finanças compete coordenar e controlar a execução das atividades relacionadas aos Sistemas de Pessoal Civil da Administração Federal - SIPEC, de Organização e Modernização Administrativa - SOMAD, de Administraçăo dos Recursos de Informação e Informática - SISP, de Serviços Gerais - SISG, de Planejamento e de Orçamento Federal, de Contabilidade Federal e de Administraçäo Financeira Federal.

\section{Seção III}

\section{Dos Órgãos Especificos Singulares}

Art. 10. Ao Departamento de Turismo de Lazer e Incentivos compete:

I - identificar e analisar as condiçōes de competitividade dos produtos turísticos brasileiros;

II - estabelecer parâmetros que possibilitem a identificação de segmentos de produtos turísticos;

III - identificar os mercados existentes e potenciais, bem como formas alternativas de comercialização dos produtos turísticos brasileiros; e

IV - desenvolver estratégias para a distribuição dos prođutos turisticos nos canais de comercialização.

Art. 11. Ao Departamento de Marketing e Relações Institucionais compete:

I - propor, coordenar, supervisionar e controlar a execução da política de marketing, de promoção e propaganda do turismo brasileiro no País e no exterior; e

II - coordenar as relaçōes entre a EMBRATUR, entidades e instituiçōes públicas e privadas; e

III - articular, sob a coordenaçăo do Ministério do Turismo, com o Congresso Nacional nos assuntos relacionados à EMBRATUR.

Art. 12. Ao Departamento de Turismo de Negócios e Eventos compete:

I-coordenar as aç̋̄es para incrementar e desenvolver a participaçăo do segmento de negócios e eventos no turismo brasileiro;

II - coordenar a participação dos segmentos turísticos brasileiros de negócios e eventos e de lazer e incentivos em eventos e atividades promocionais voltadas ao incremento do fluxo turístico no território brasileiro e no mercado internacional; e 
III - ampliar a participação do Brasil no mercado internacional do turismo. no segmento de negócios e eventos.

Art. 13. Ao Departamento de Estudos e Pesquisas compete:

I-propor, coordenar, supervisionar e apoiar a realizaçăo de estudos, pesquisas, análises. levantamentos e sistematização de dados estatisticos sobre o setor turístico, com o objetivo de orientar as políticas públicas e subsidiar a tomada de decisăo da iniciativa privada;

II - criar base de dados de informaçöes gerenciais sobre a oferta e demanda turistica para apoiar a tomada de decisão nas áreas pública e privada;

III - realizar estudos e pesquisas sobre oportunidades de investimentos na área de turismo; e

IV - interagir com instituiçōes correlatas em nivel nacional e internacional, buscando o constante aprimoramento da área de pesquisa e informação turística.

\section{CAPITULO V}

\section{DAS ATRIBUIÇÕES DOS DIRIGENTES}

Art. 14. Ao Presidente incumbe:

I - planejar, dirigir, coordenar e controlar a execução das atividades da EMBRATUR:

II - orientar e coordenar o funcionamento geral da EMBRATUR em todos os setores de suas atividades. zelando pelo fiel cumprimento da Lei $n^{2}$ 8.181, de 1991. assim como da política geral e dos planos, programas e projetos da Autarquia;

III - firmar, em nome da EMBRATUR, contratos, convênios, acordos, ajustes e outros instrumentos similares; e EMBRATUR.

IV - praticar os atos necessários à gestăo técnica, administrativa, orçamentária e financeira da

Art. 15. Aos Diretores, ao Procurador-Jurídico, ao Auditor-Chefe, ao Chefe de Gabinete, ao Chefe da Assessoria e aos demais dirigentes incumbe planejar, dirigir e coordenar a execuçåo das atividades afetas as suas respectivas unidades organizacionais, bem como exercer outras atribuiçōes que lhes forem cometidas pelo Presidente da EMBRATUR.

\section{CAPITULO VI}

\section{DAS DISPOSIÇŌES GERAIS}

Art. 16. O regimento interno definirá o detalhamento das unidades integrantes da Estrutura Regimental da EMBRATUR, as competências das respectivas unidades e as atribuiçōes de seus dirigentes.

\section{ANEXO II}

a. QUADRO DEMONSTRATIVO DOS CARGOS EM COMISSẢO E DAS FUNÇŌES GRATIFICADAS DA EMBRATUR.

\begin{tabular}{|l|c|c|c|}
\hline UNIDADE & CARGOI & $\begin{array}{r}\text { DENOMINAÇÃO } \\
\text { CARGO/FUNÇĀO }\end{array}$ & OASI \\
\hline & FUNÇĂO & FG \\
\hline & 1 & Presidente & 101.6 \\
\hline
\end{tabular}




\begin{tabular}{|c|c|c|c|}
\hline & 2 & Assessor & 102.4 \\
\hline \multirow[t]{7}{*}{ GABINETE } & 1 & Chefe de Gabinete & 101.4 \\
\hline & 3 & Assessor Técnico & 102.3 \\
\hline & 3 & Assistente & 102.2 \\
\hline & 2 & Assistente Técnico & 102.1 \\
\hline & 1 & & FG-1 \\
\hline & 1 & & FG-2 \\
\hline & 1 & & FG-3 \\
\hline \multicolumn{4}{|l|}{ Assessoria de Comunicaçăo } \\
\hline \multirow[t]{3}{*}{ Social } & 1 & Chefe da Assessoria & 101.4 \\
\hline & 2 & Assessor Técnico & 102.3 \\
\hline & 1 & Assistente & 102.2 \\
\hline PROCURADORIA -JURÍDICA & 1 & Procurador-Jurídico & 101.4 \\
\hline Divisäo & 2 & Chefe & 101.2 \\
\hline AUDITORIA INTERNA & 1 & Auditor-Chefe & 101.4 \\
\hline Divisäo & 2 & Chefe & 101.2 \\
\hline \multicolumn{4}{|l|}{ DEPARTAMENTO DE } \\
\hline \multirow[t]{5}{*}{ ADMINISTRAÇĀO E FINANÇAS } & 1 & Diretor & 101.5 \\
\hline & 1 & Assistente Técnico & 102.1 \\
\hline & 1 & & FG-1 \\
\hline & 1 & & FG-2 \\
\hline & 1 & & FG-3 \\
\hline Coordenaçăo-Geral de Administraçåo & 1 & Coordenador-Geral & 101.4 \\
\hline Divisão & 3 & Chefe & 101.2 \\
\hline Serviço & 4 & Chefe & 101.1 \\
\hline Coordenação-Geral de Finanças & 1 & Coordenador-Geral & 101.4 \\
\hline Divisão & 3 & Chefe & 101.2 \\
\hline Serviço & 4 & Chefe & 101.1 \\
\hline
\end{tabular}




\begin{tabular}{|c|c|c|c|}
\hline Coordenação-Geral de Informaçảo & 1 & Coordenador-Geral & 101.4 \\
\hline Divisão & 3 & Chefe & 101.2 \\
\hline \multicolumn{4}{|l|}{ DEPARTAMENTO DE TURISMO OE } \\
\hline \multirow[t]{2}{*}{ LAZER E INCENTIVOS } & 1 & Diretor & 101.5 \\
\hline & 1 & Assistente Técnico & 102.1 \\
\hline \multicolumn{4}{|l|}{ Coordenaçăo-Geral de Apoio à } \\
\hline Comercializaçăo & 1 & Coordenador-Geral & 101.4 \\
\hline Divisåo & 3 & Chefe & 101.2 \\
\hline $\begin{array}{l}\text { Coordenaçăo-Geral de Segmentação e } \\
\text { Produtos }\end{array}$ & 1 & Coordenador-Geral & 101.4 \\
\hline Divisăo & 2 & Chefe & 101.2 \\
\hline Serviço & 1 & Chefe & 101.1 \\
\hline Coordenaçăo-Geral de Novos Mercados & 1 & Coordenador-Geral & 101.4 \\
\hline Divisão & 2 & Chefe & 101.2 \\
\hline \multicolumn{4}{|l|}{ OEPARTAMENTO DE MARKETING E } \\
\hline \multirow[t]{3}{*}{ RELAÇOES INSTITUCIONAIS } & 1 & Diretor & 101.5 \\
\hline & 2 & Assistente Técnico & 102.1 \\
\hline & 1 & Assessor Técnico & 102.3 \\
\hline Coordenaçăo-Geral de Propaganda & 1 & Coordenador-Geral & 101.4 \\
\hline Divisăo & 3 & Chefe & 101.2 \\
\hline Serviço & 1 & Chefe & 101.1 \\
\hline $\begin{array}{l}\text { Coordenaçăo-Geral de Relações } \\
\text { Institucionais }\end{array}$ & 1 & Coordenador-Geral & 101.4 \\
\hline Divisăo & 3 & Chefe & 101.2 \\
\hline \multicolumn{4}{|l|}{ DEPARTAMENTO DE TURISMO DE } \\
\hline \multirow[t]{2}{*}{ NEGÓCIOS E EVENTOS } & 1 & Diretor & 101.5 \\
\hline & 1 & Assessor Técnico & 102.3 \\
\hline Coordenação-Geral de Turismo de Eventos & 1 & Coordenador-Geral & 101.4 \\
\hline Divisão & 3 & Chefe & 101.2 \\
\hline
\end{tabular}




\begin{tabular}{|c|c|c|c|}
\hline $\begin{array}{l}\text { Coordenação-Geral de Eventos } \\
\text { Promocionais }\end{array}$ & 1 & Coordenador-Geral & 101.4 \\
\hline Coordenação & 1 & Coordenador & 101.3 \\
\hline Divisăo & 1 & Chefe & 101.2 \\
\hline Serviço & 1 & Chefe & 101.1 \\
\hline Coordenaçăo-Geral de Turismo de Negócios & 1 & Coordenador-Geral & 101.4 \\
\hline Divisăo & 2 & Chefe & 101.2 \\
\hline Serviço & 1 & Chefe & 101.1 \\
\hline \multicolumn{4}{|l|}{ DEPARTAMENTO DE ESTUDOS E } \\
\hline \multirow[t]{2}{*}{ PESQUISAS } & 1 & Diretor & 101.5 \\
\hline & 1 & Assessor Técnico & 102.3 \\
\hline Coordenaçăo-Geral de Estudos E Pesquisas & 1 & Coordenador-Geral & 101.4 \\
\hline Divisão & 3 & Chefe & 101.2 \\
\hline $\begin{array}{l}\text { Coordenaçăo-Geral de Informações } \\
\text { Gerenciais }\end{array}$ & 1 & Coordenador-Geral & 101.4 \\
\hline Divisāo & 2 & Chefe & 101.2 \\
\hline
\end{tabular}

b) QUADRO RESUMO DE CUSTOS DOS CARGOS EM COMISSÃO E DAS FUNÇÕES GRATIFICADAS DA EMBRATUR

\begin{tabular}{|c|c|c|c|c|c|}
\hline \multirow{2}{*}{ CÓDIGo } & \multirow{2}{*}{$\begin{array}{c}\text { DAS- } \\
\text { UNITÁRIO }\end{array}$} & \multicolumn{2}{|c|}{ SITUAÇÃO ATUAL } & \multicolumn{2}{|c|}{ SITUAÇĂO NOVA } \\
\hline & & QTDE. & VALOR TOTAL & QTDE. & VALOR TOTAL \\
\hline DAS 101.6 & 6,15 & 1 & 6.15 & 1 & 6.15 \\
\hline DAS 101.5 & 5,16 & 5 & 25,80 & 5 & 25,80 \\
\hline DAS 101.4 & 3,98 & 21 & 83,58 & 17 & 67,66 \\
\hline DAS 101.3 & 1,28 & - & - & 1 & 1,28 \\
\hline DAS 101.2 & 1,14 & 40 & 45,60 & 37 & 42,18 \\
\hline DAS 101.1 & 1,00 & 14 & 14,00 & 12 & 12,00 \\
\hline DAS 102.4 & 3,98 & 1 & 3,98 & 2 & 7,96 \\
\hline DAS 102.3 & 1,28 & 5 & 6,40 & 8 & 10,24 \\
\hline DAS 102.2 & 1,14 & 6 & 6.84 & 4 & 4,56 \\
\hline DAS 102.1 & 1,00 & 8 & 8,00 & 6 & 6,00 \\
\hline
\end{tabular}




\begin{tabular}{|c|c|c|c|c|c|}
\hline \multicolumn{2}{|c|}{ SUBTOTAL 1} & 101 & 200,35 & 93 & 183,83 \\
\hline FG-1 & 0,20 & 13 & 2,60 & 2 & 0.40 \\
\hline FG-2 & 0.15 & 14 & 2,10 & 2 & 0.30 \\
\hline FG-3 & 0.12 & 16 & 1,92 & 2 & 0,24 \\
\hline \multicolumn{2}{|c|}{ SUBTOTAL 2} & 43 & 6,62 & 6 & 0,94 \\
\hline \multicolumn{2}{|c|}{ TOTAL (1+2) } & 144 & 206,97 & 99 & 184,77 \\
\hline
\end{tabular}

ANEXO III

REMANEJAMENTO DE CARGOS

\begin{tabular}{|c|c|c|c|c|c|}
\hline \multirow[t]{2}{*}{ cóolgo } & \multirow{2}{*}{$\begin{array}{l}\text { DAS- } \\
\text { UNITÁRIO }\end{array}$} & \multicolumn{2}{|c|}{$\begin{array}{l}\text { DA SEGES/MP P/A } \\
\text { EMBRATUR (a) }\end{array}$} & \multicolumn{2}{|c|}{$\begin{array}{l}\text { DA EMBRATUR P/A } \\
\text { SEGES/MP (b) }\end{array}$} \\
\hline & & QTOE & VALOR TOTAL & QTDE & VALOR TOTAL \\
\hline DAS 101.4 & 3,98 & - & - & 4 & 15,92 \\
\hline DAS 101.3 & 1,28 & 1 & 1,28 & & \\
\hline DAS 101.2 & 1,14 & $\cdot$ & - & 3 & 3,42 \\
\hline DAS 101.1 & 1,00 & - & - & 2 & 2.00 \\
\hline DAS-102.4 & 3,98 & 1 & 3,98 & - & - \\
\hline DAS 102.3 & 1,28 & 3 & 3,84 & - & - \\
\hline DAS 102.2 & 1,14 & - & - & 2 & 2,28 \\
\hline DAS 102.1 & 1,00 & - & - & 2 & 2,00 \\
\hline \\
\hline \multicolumn{2}{|c|}{ SUBTOTAL 1} & 5 & 9,10 & 13 & 25,62 \\
\hline FG-1 & 0,20 & - & $\cdot$ & 11 & 2,20 \\
\hline FG-2 & 0,15 & - & - & 12 & 1,80 \\
\hline FG-3 & 0,12 & - & - & 14 & 1,68 \\
\hline \multicolumn{2}{|c|}{ SUBTOTAL 2} & $\cdot$ & $\cdot$ & 37 & 5,68 \\
\hline \multicolumn{2}{|c|}{ TOTAL } & 5 & 9,10 & 50 & 31,30 \\
\hline \multicolumn{2}{|c|}{$\begin{array}{l}\text { SALDO DO REMANEJAMENTO } \\
\qquad(\mathrm{a}-\mathrm{b})\end{array}$} & $\cdot$ & - & 45 & $-22,20$ \\
\hline
\end{tabular}


ANEXO II

Primeira Folhetaria Nacional da EMBRATUR 


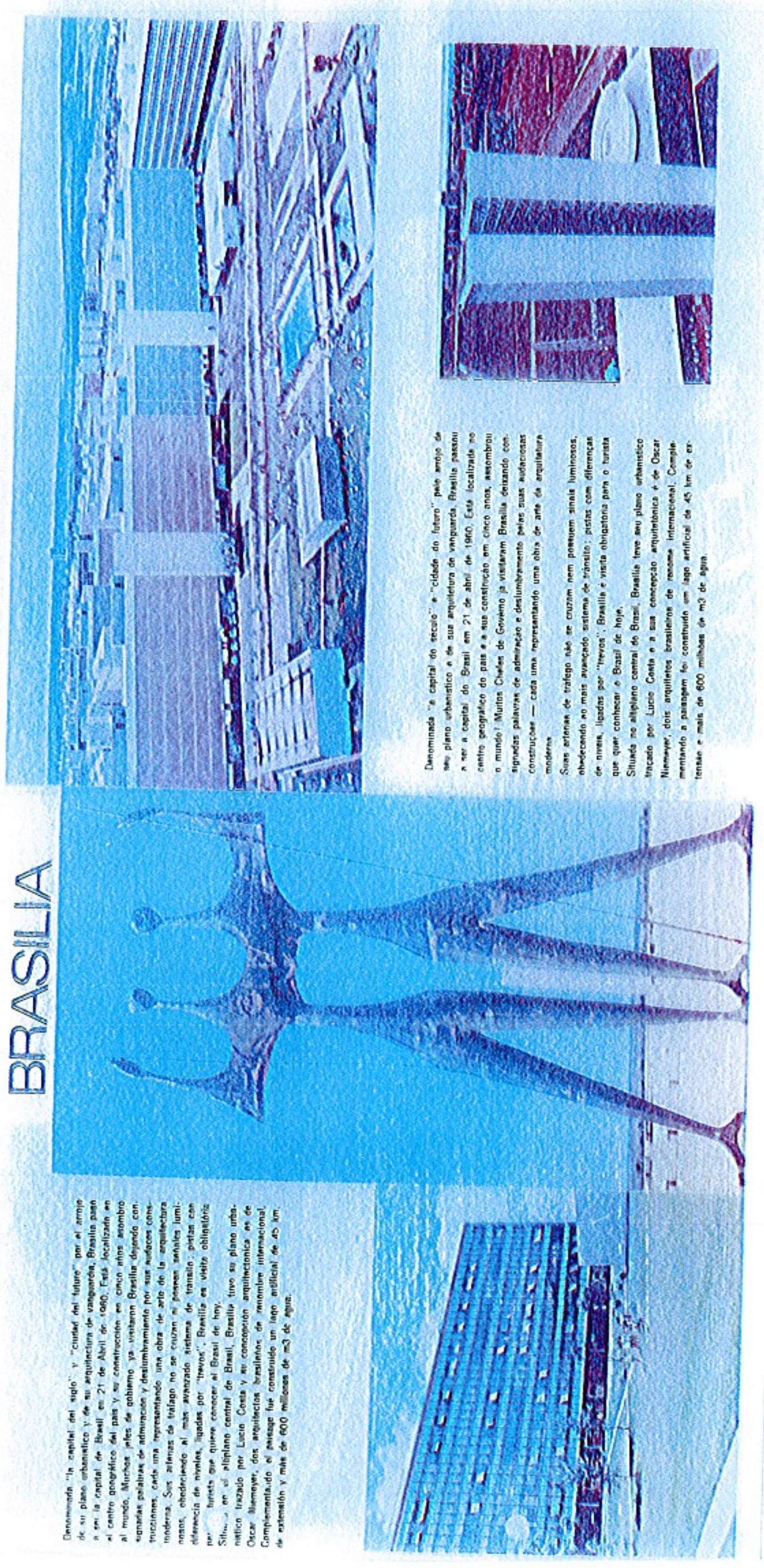



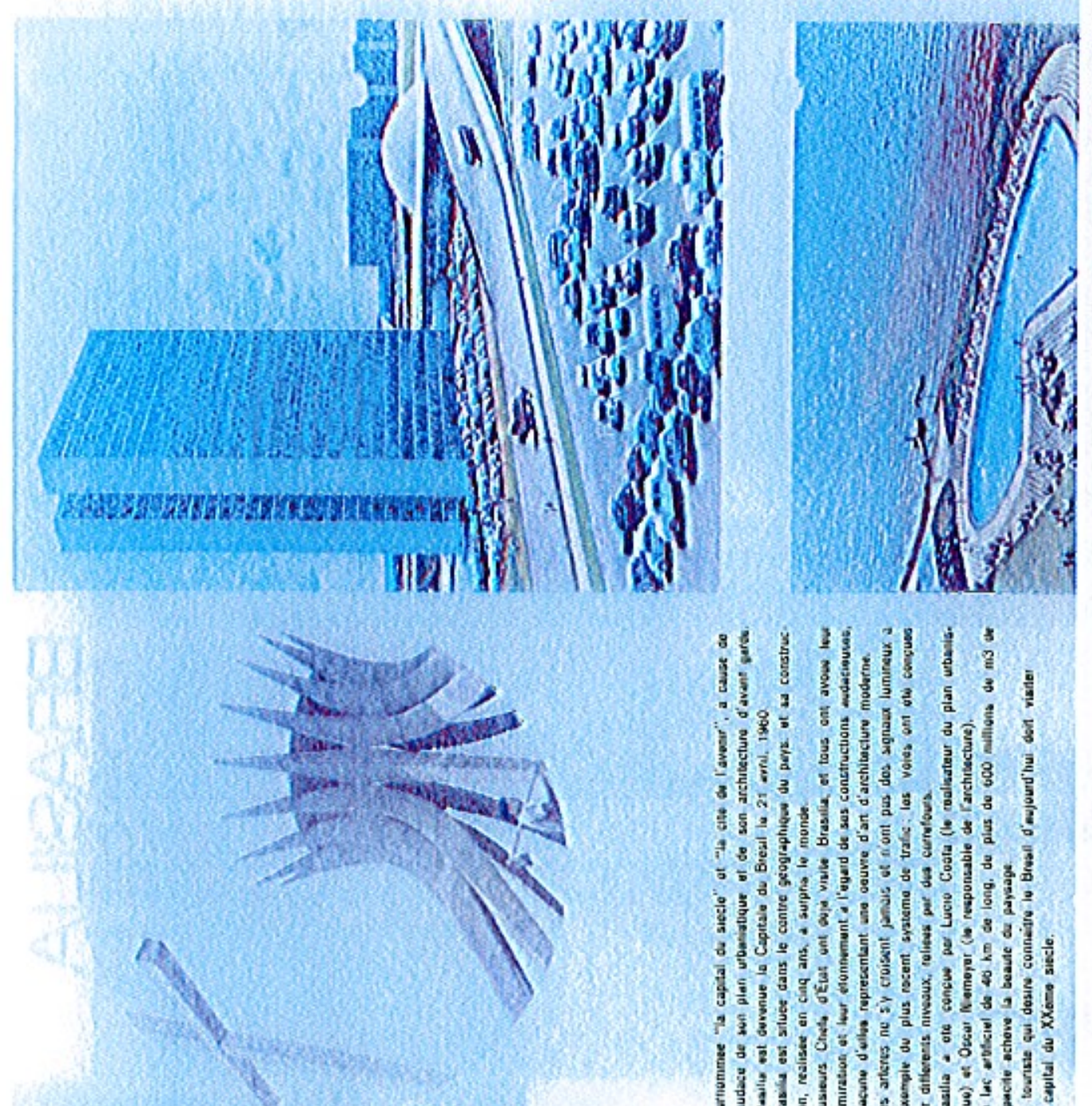

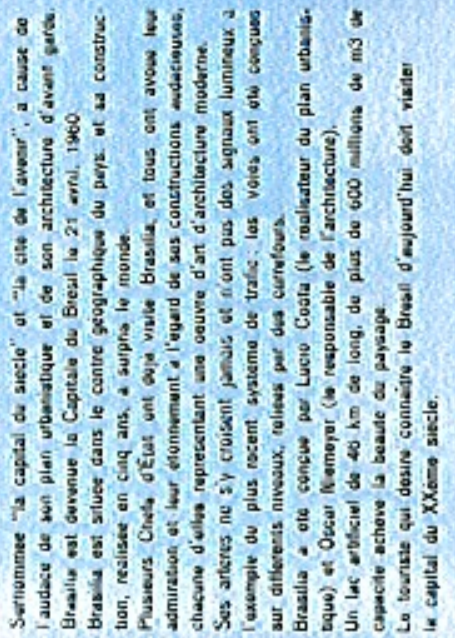

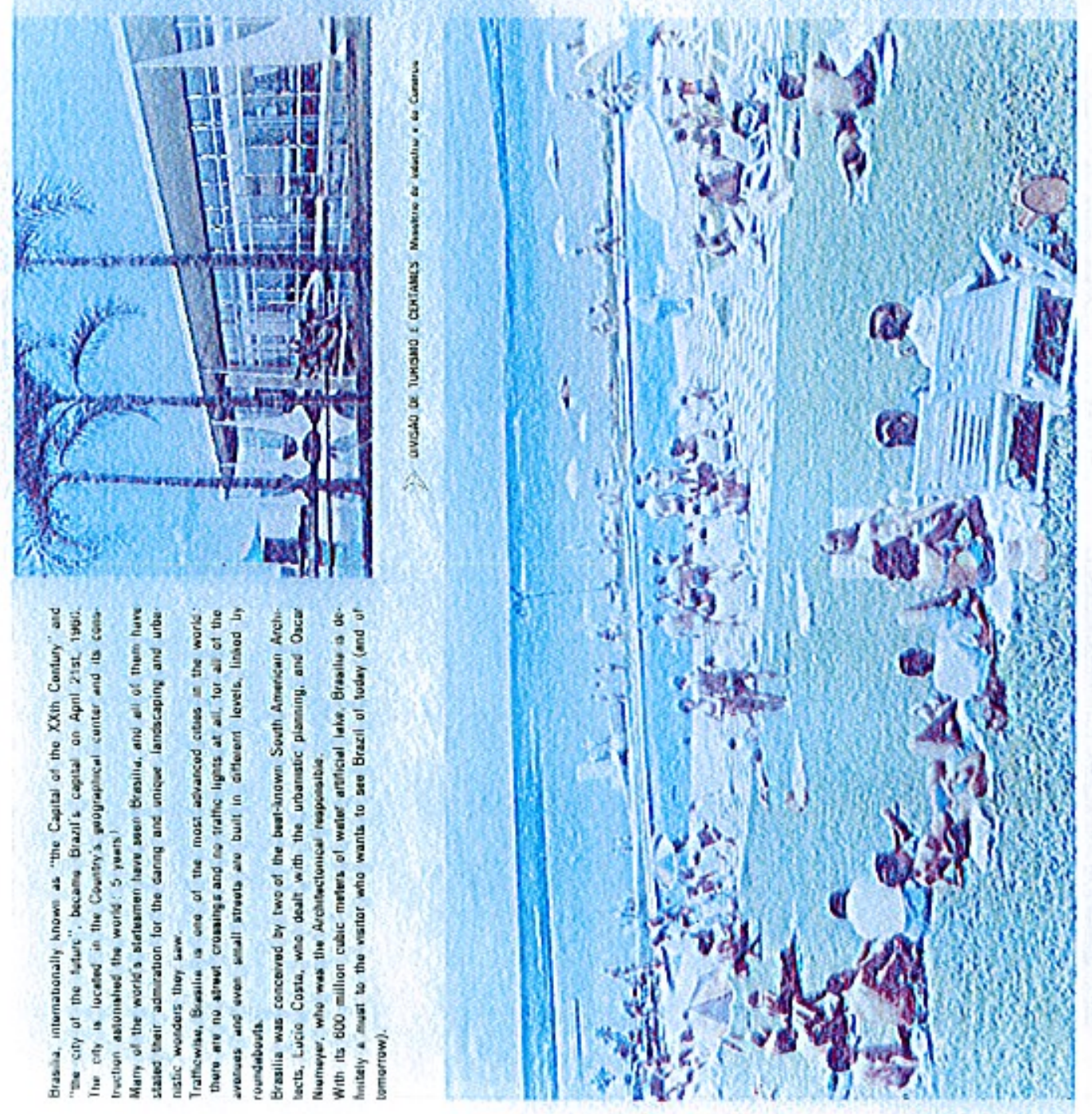



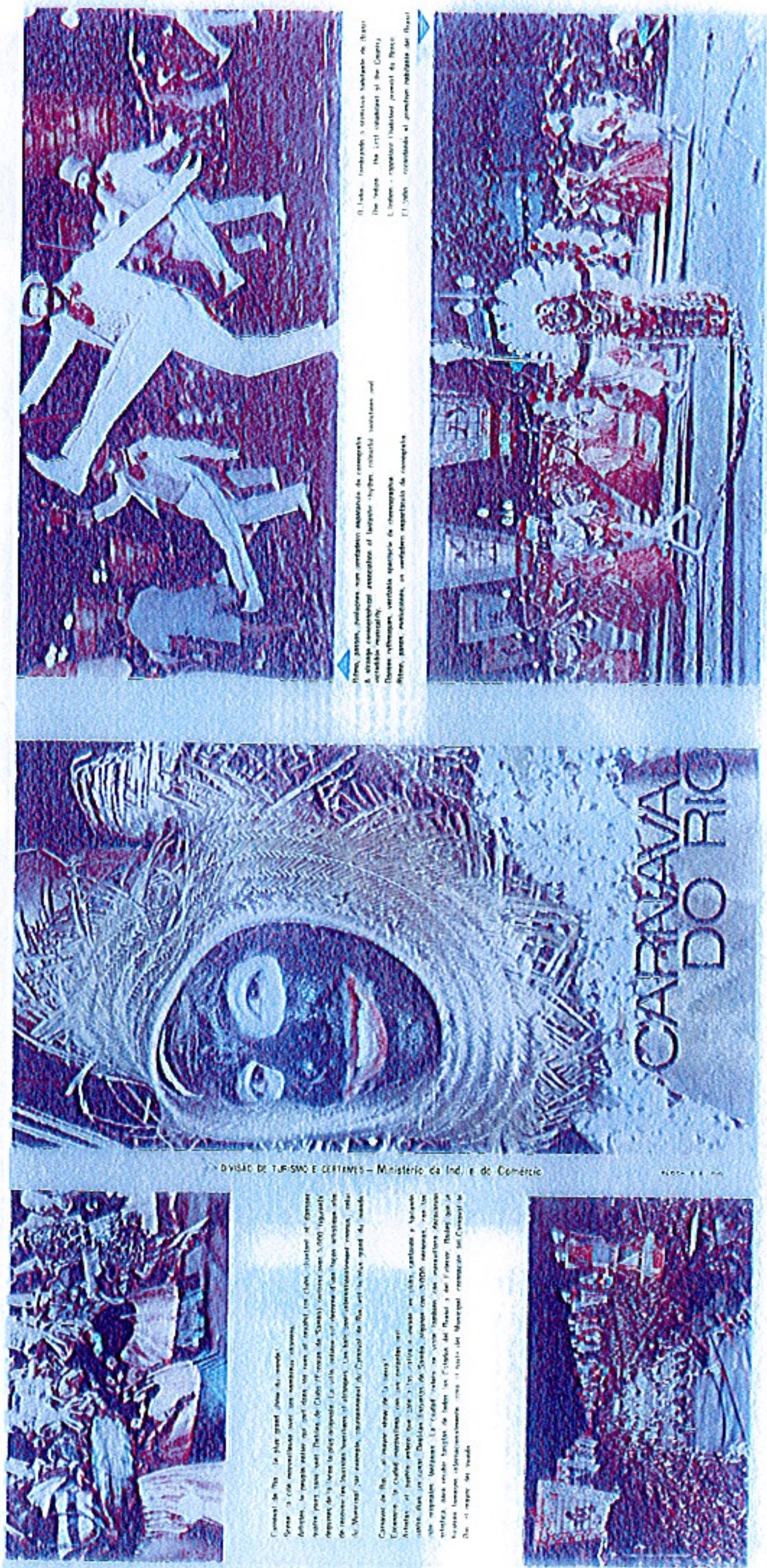

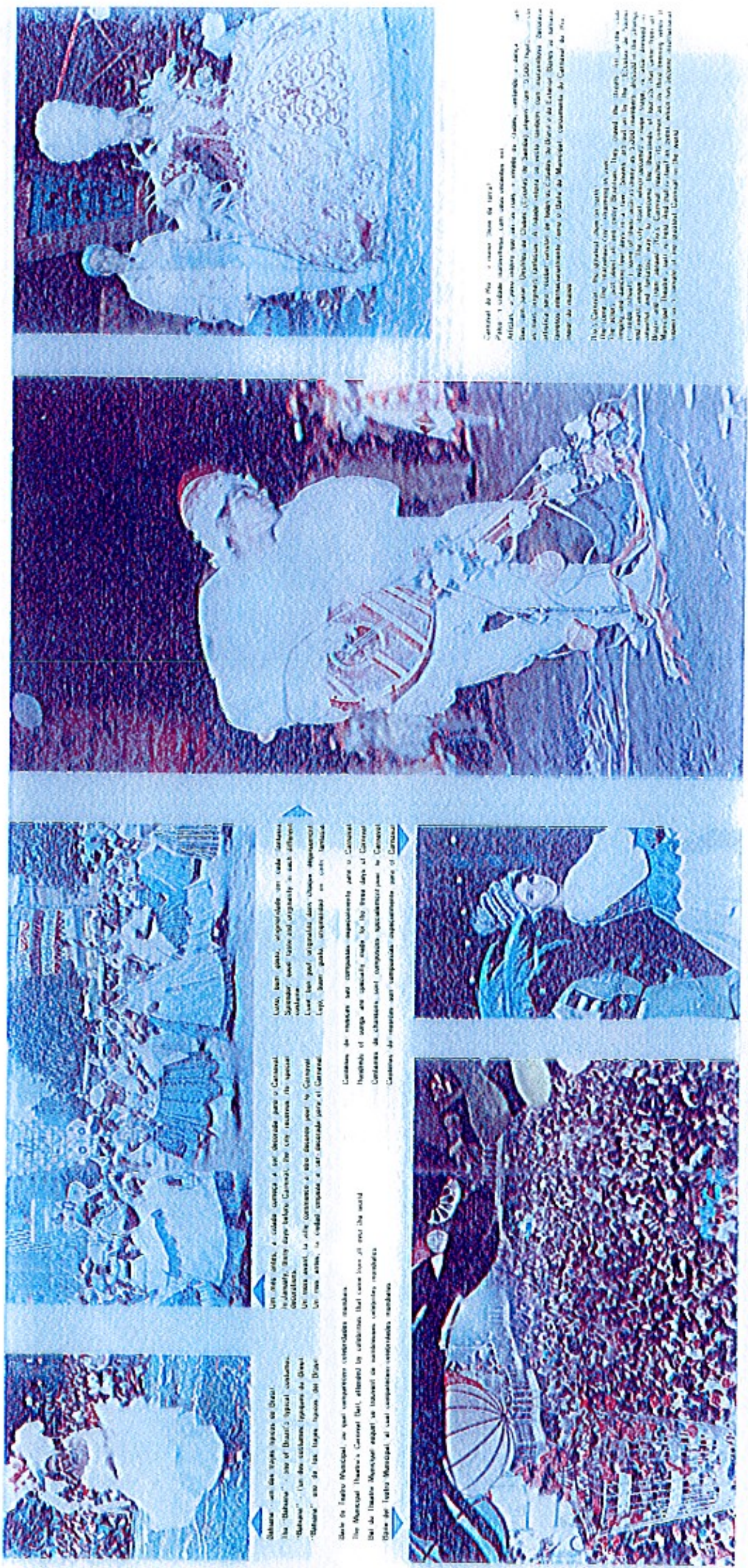


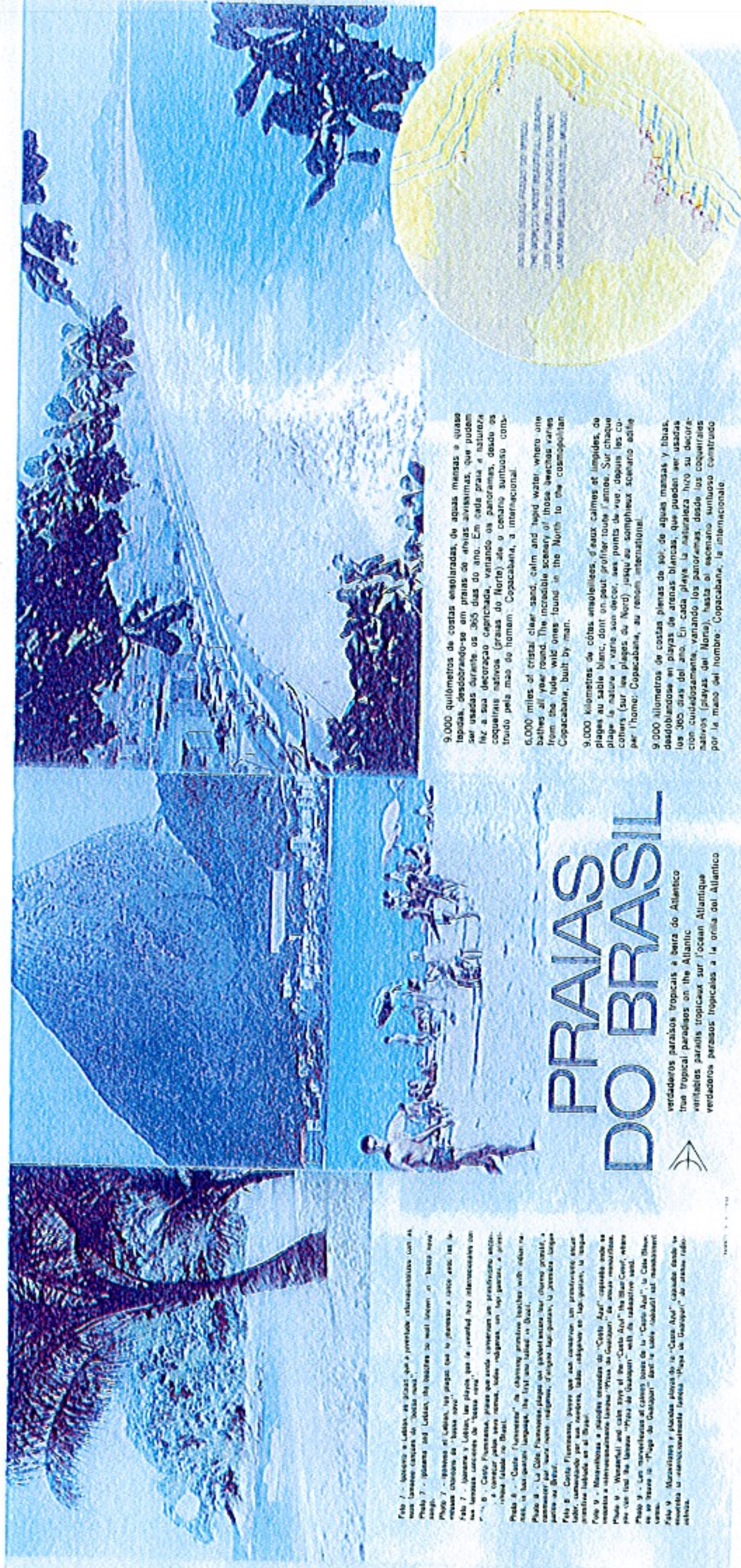



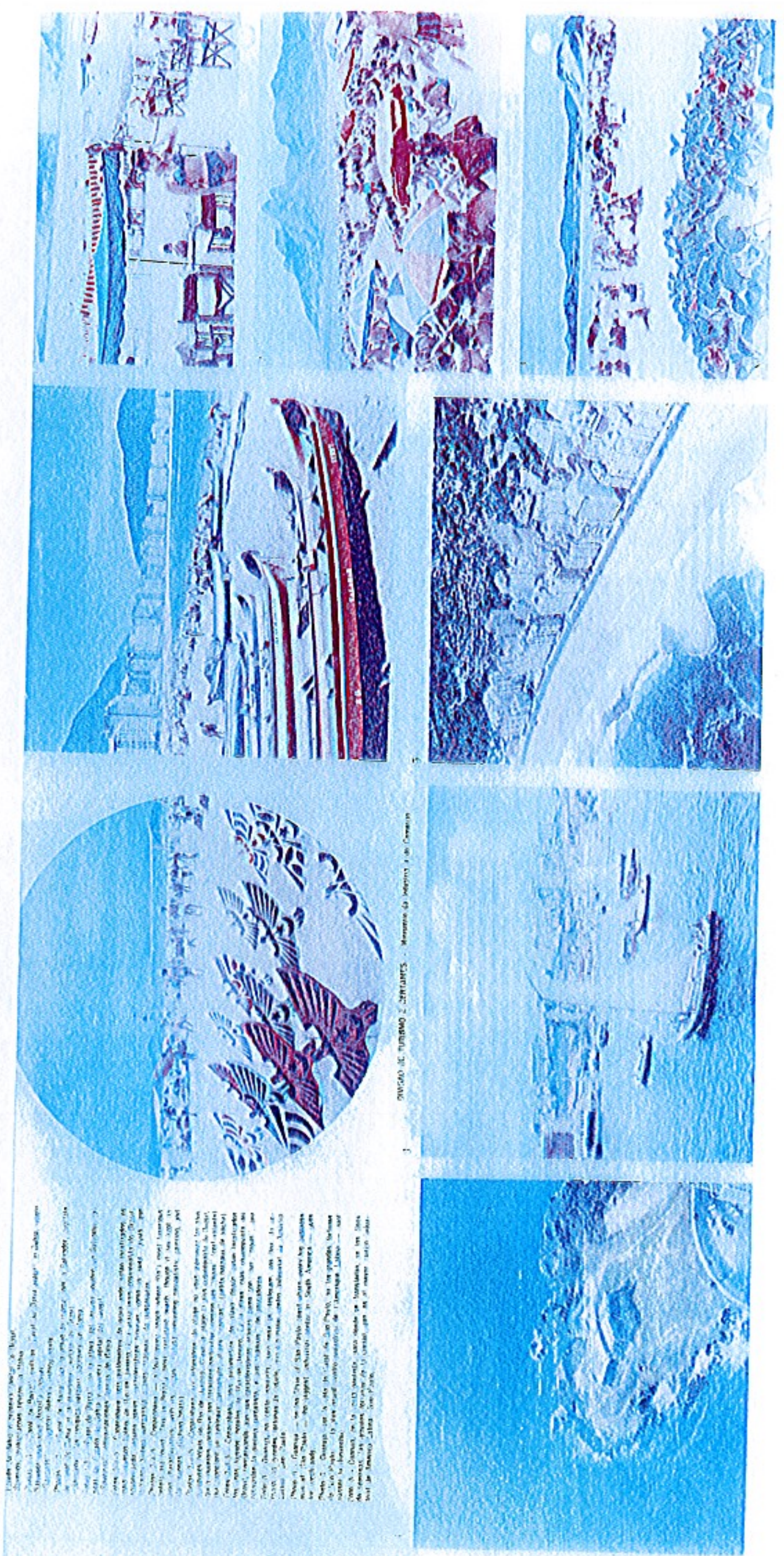

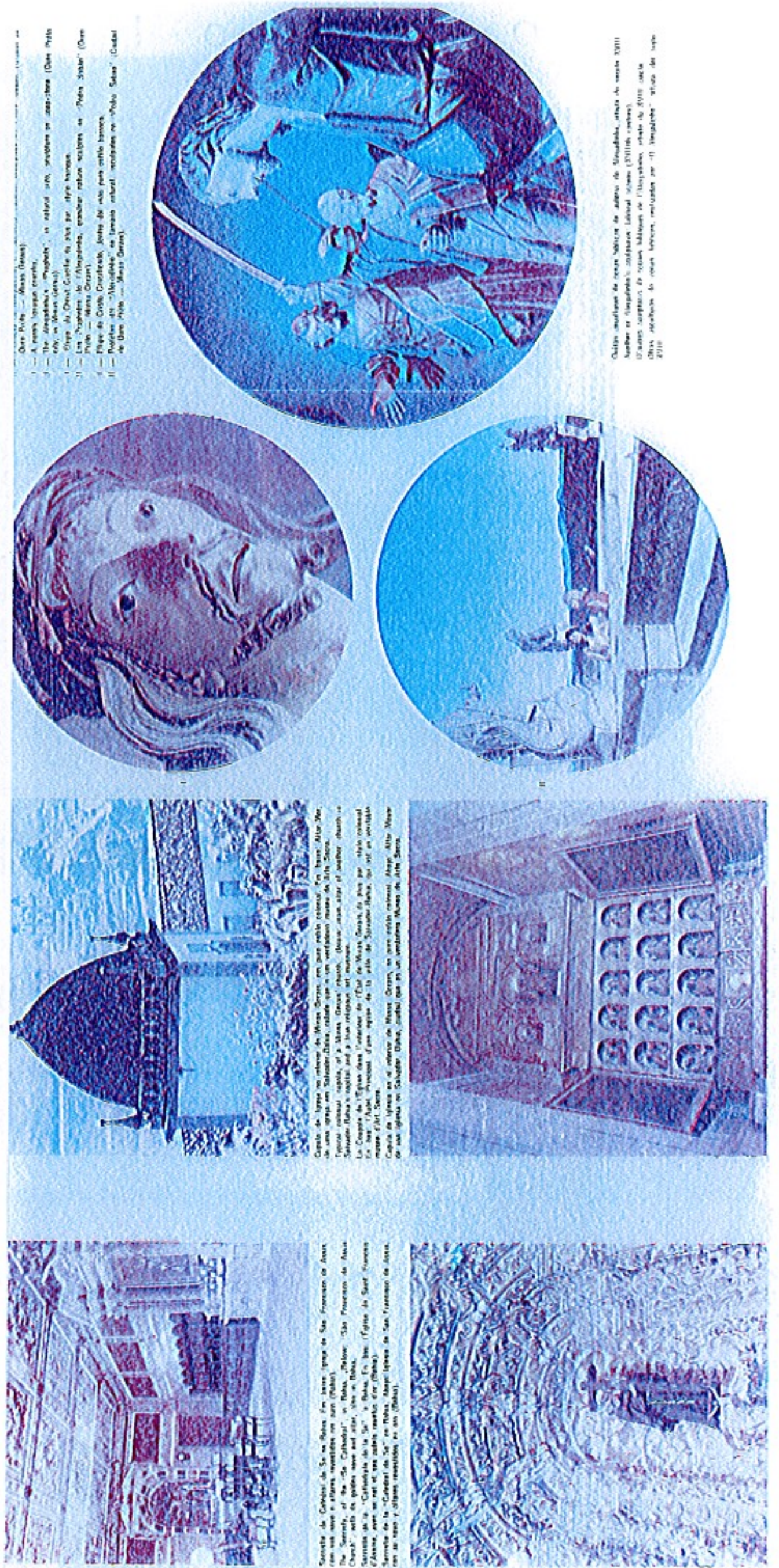
ANEXO III

Fotos dos ex-presidentes

Miguel Colasuonno e João Dória Junior 


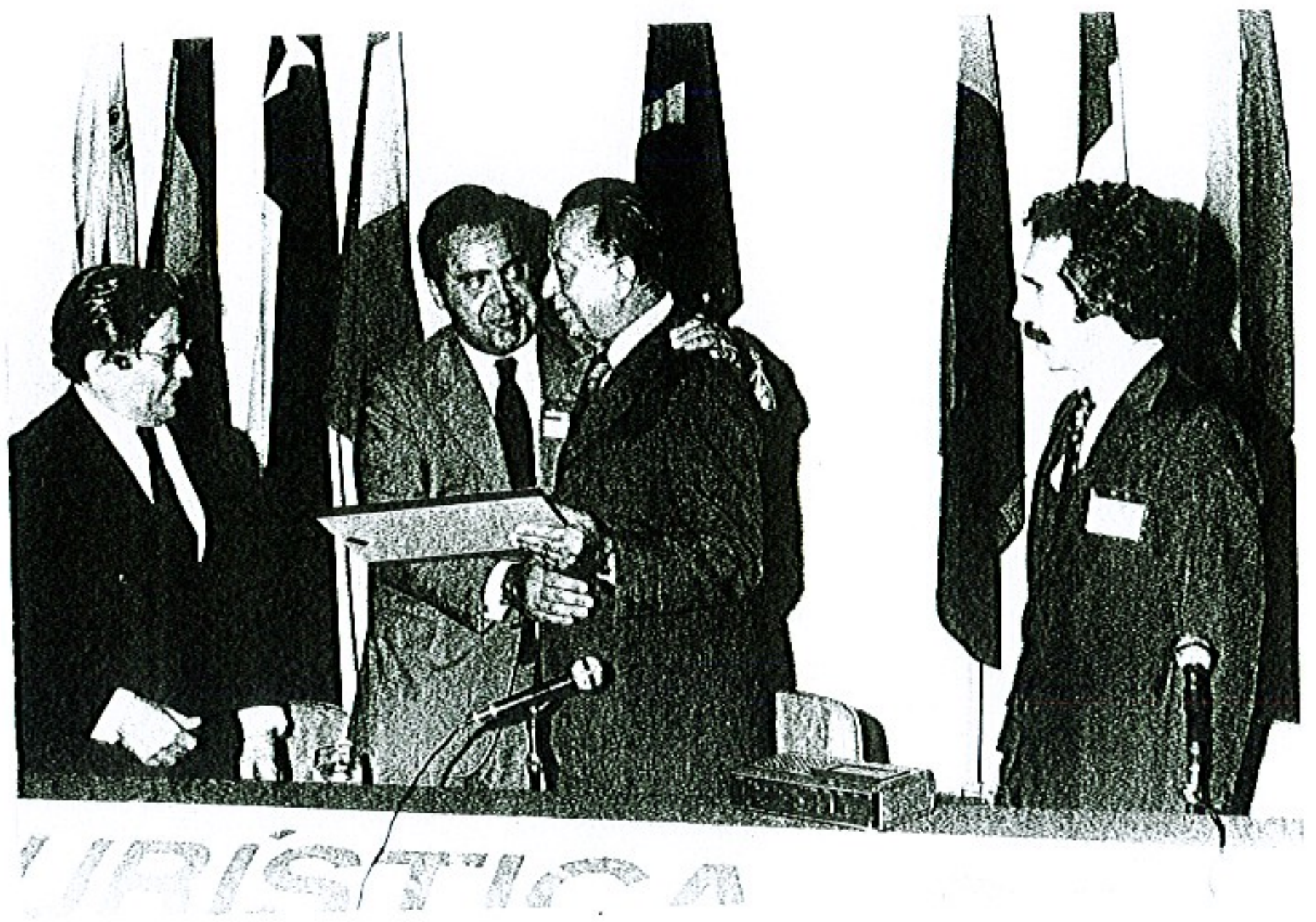

PROF MIGUEL COLASUONNO, PRESIDENTE DA EMBRATUR, PERNADOR DO DF, LAMAISON E HAROLDO DE OLIVEIRA 


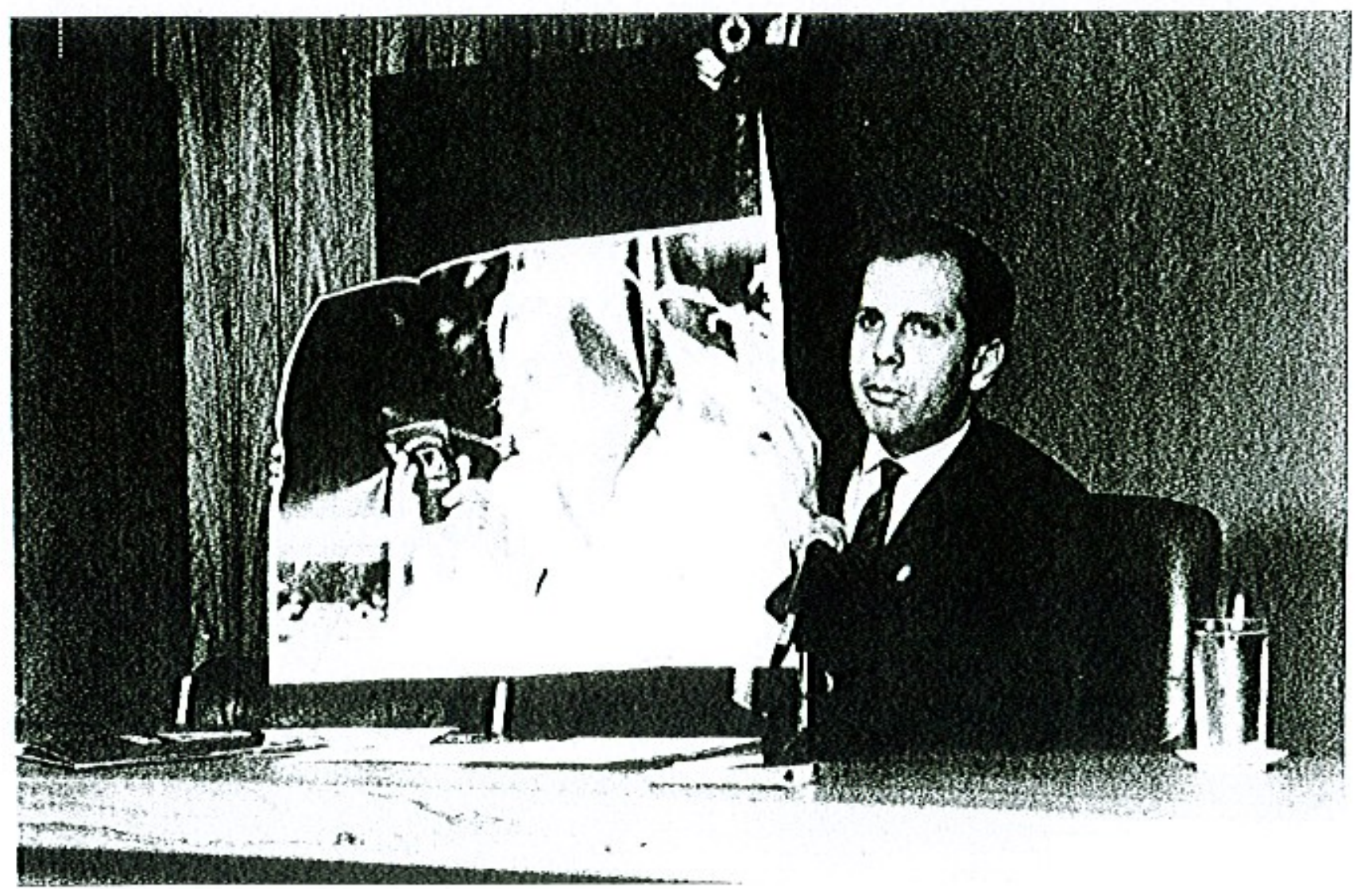

O PRESIOENTE DA EMBRATUR, JOÃO DÓRIA JR., PROMOCIONAL DO PASSAPORTE BRASIL, QUE USA A IMAGEM DE TOM JOBIM 
ANEXO IV

Campanhas Promocionais no período 1987-1988 


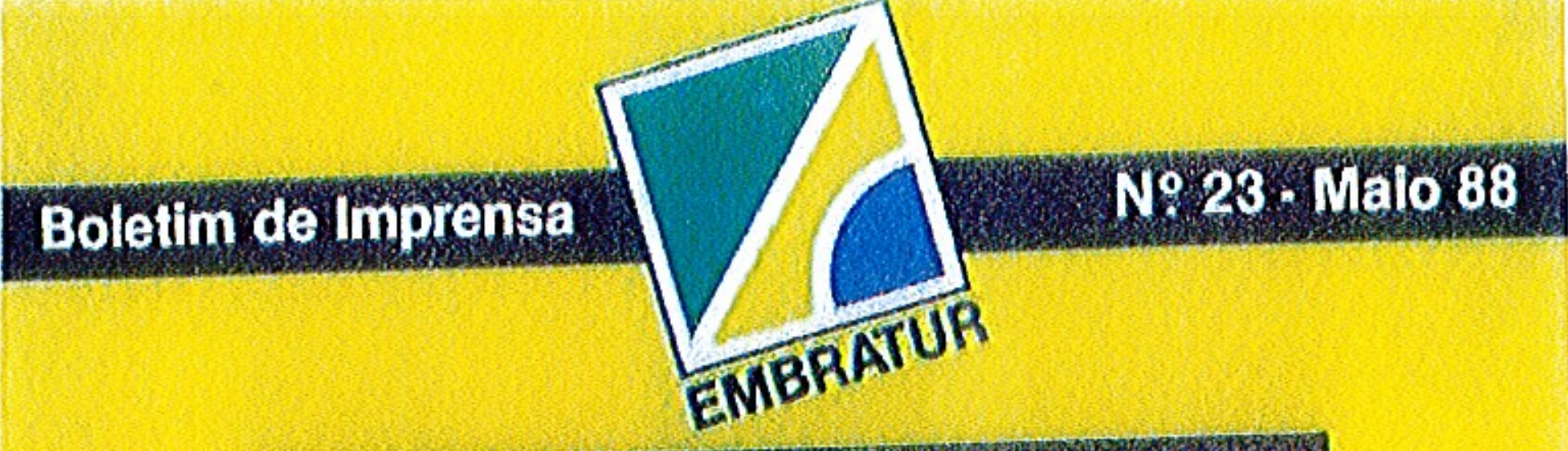




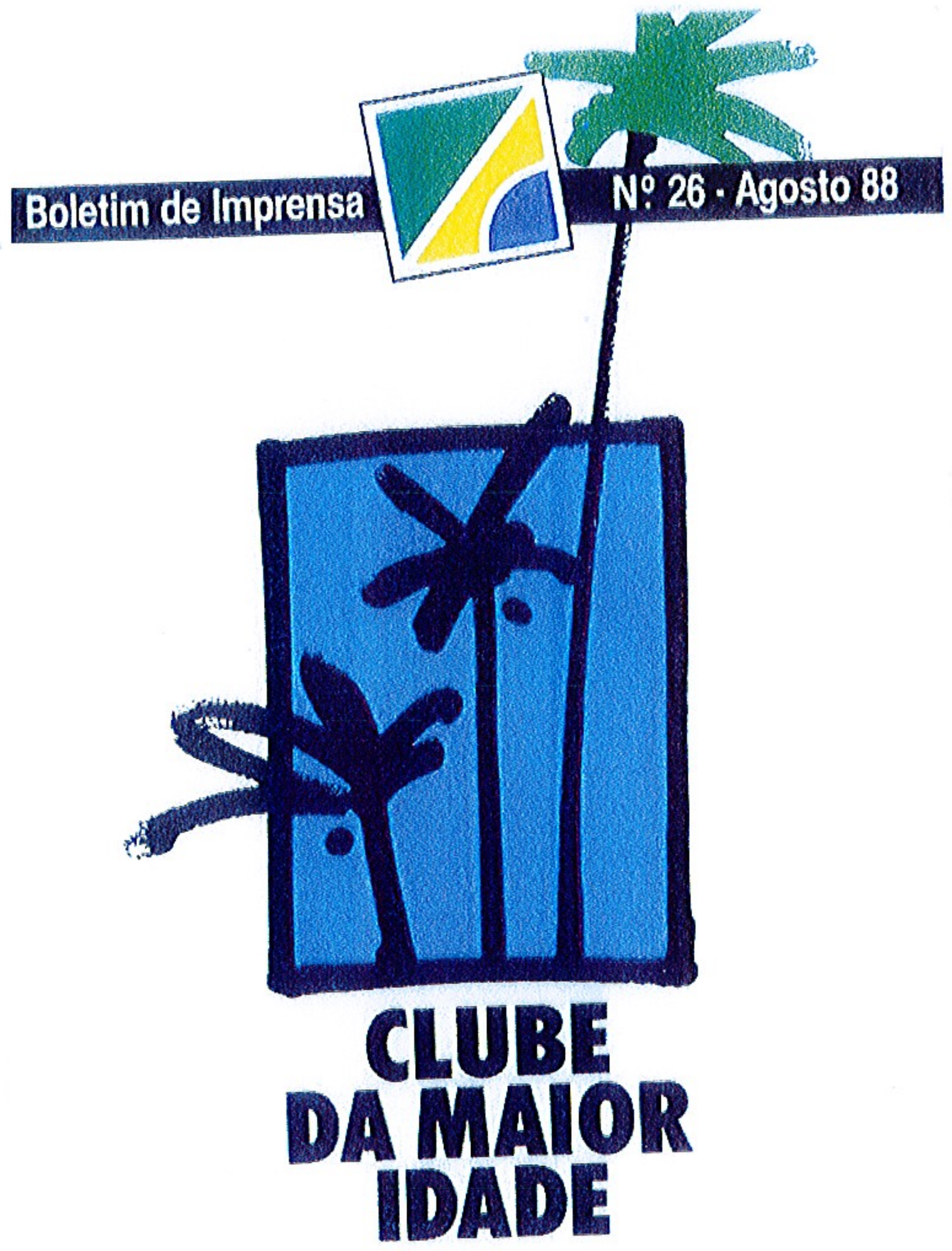




\section{GUIA DE VIAIE 888189}

ALBERGUE DE LA JUNENTUD

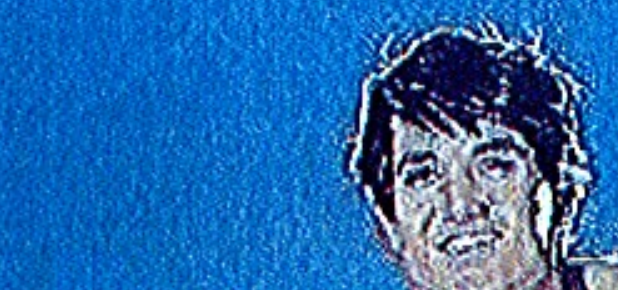

(6)
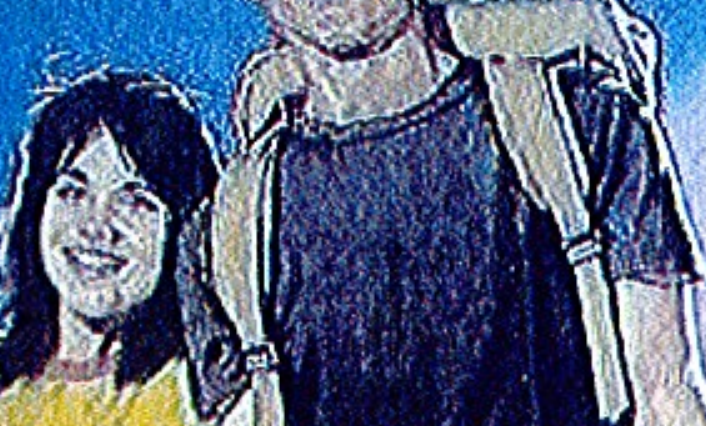

(1)

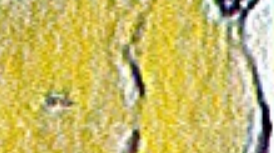

13

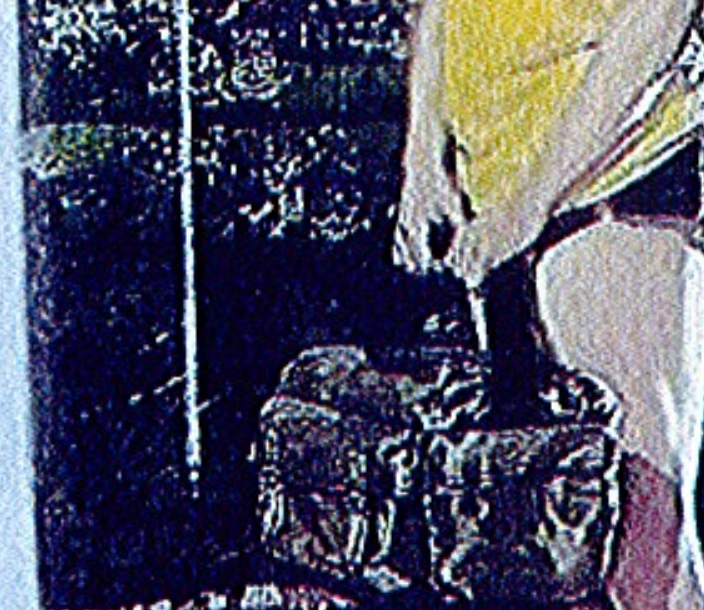

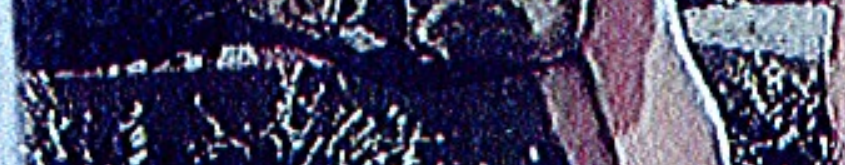

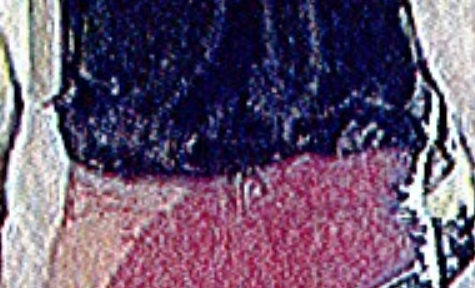
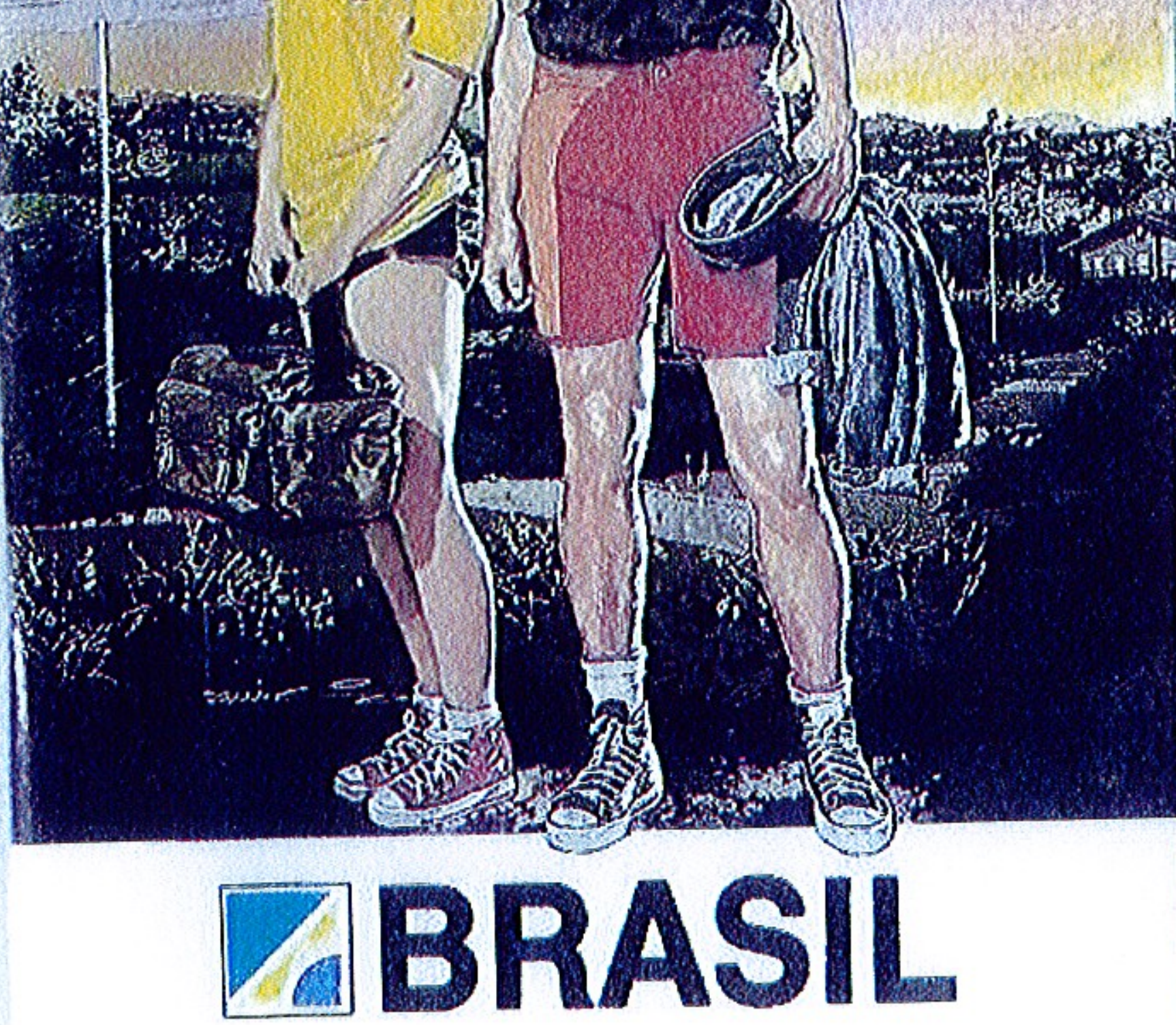


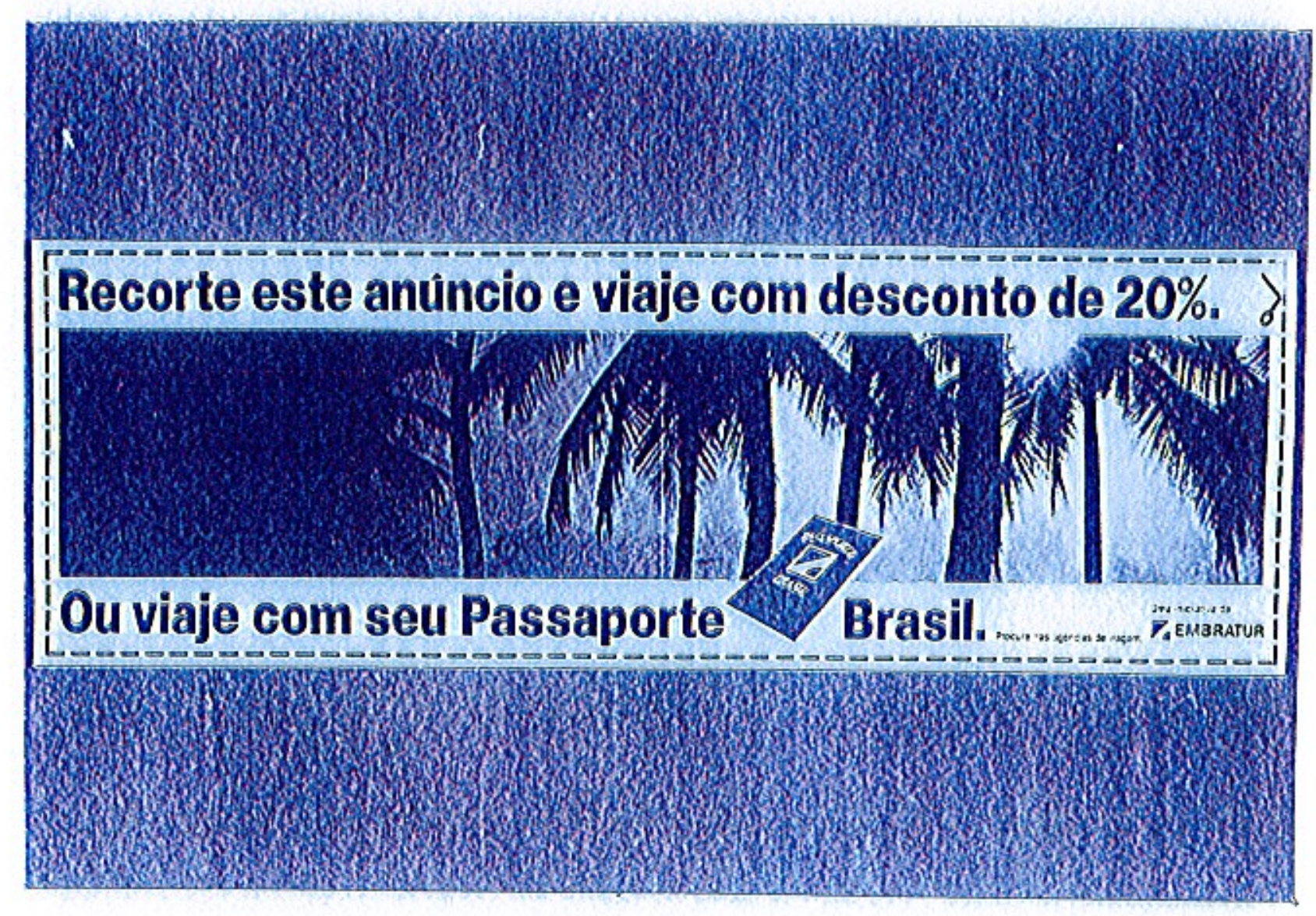

OUTDOOR - CAMPANHA PASSAPORTE BRASIL

EMBRATUR 

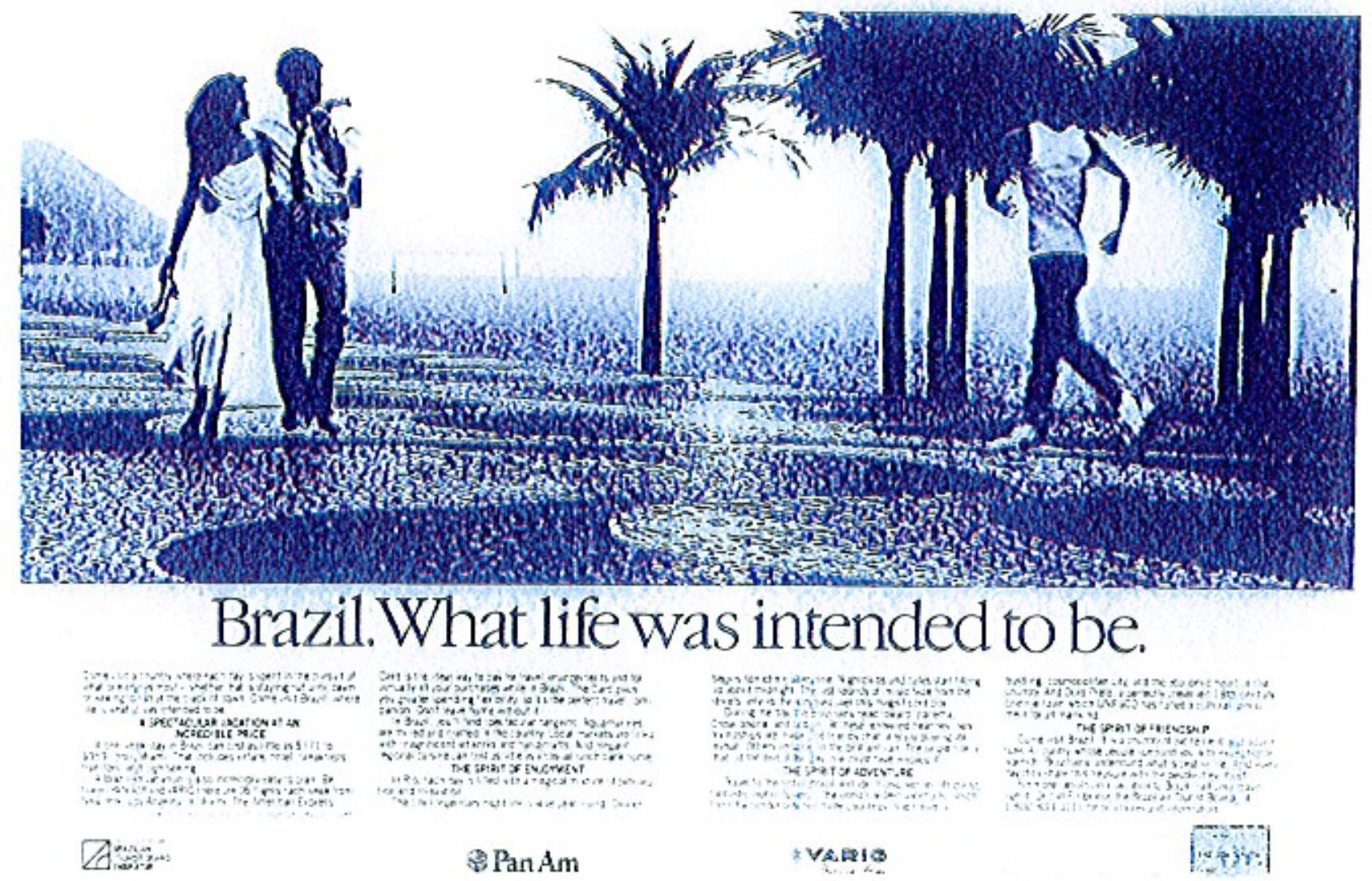

ANÚNCIO VEICULADO NO MERCAOO AMERICANO

EMBRATURNARIG/PAN AM/ AMERICANI EXPRESS CARO 


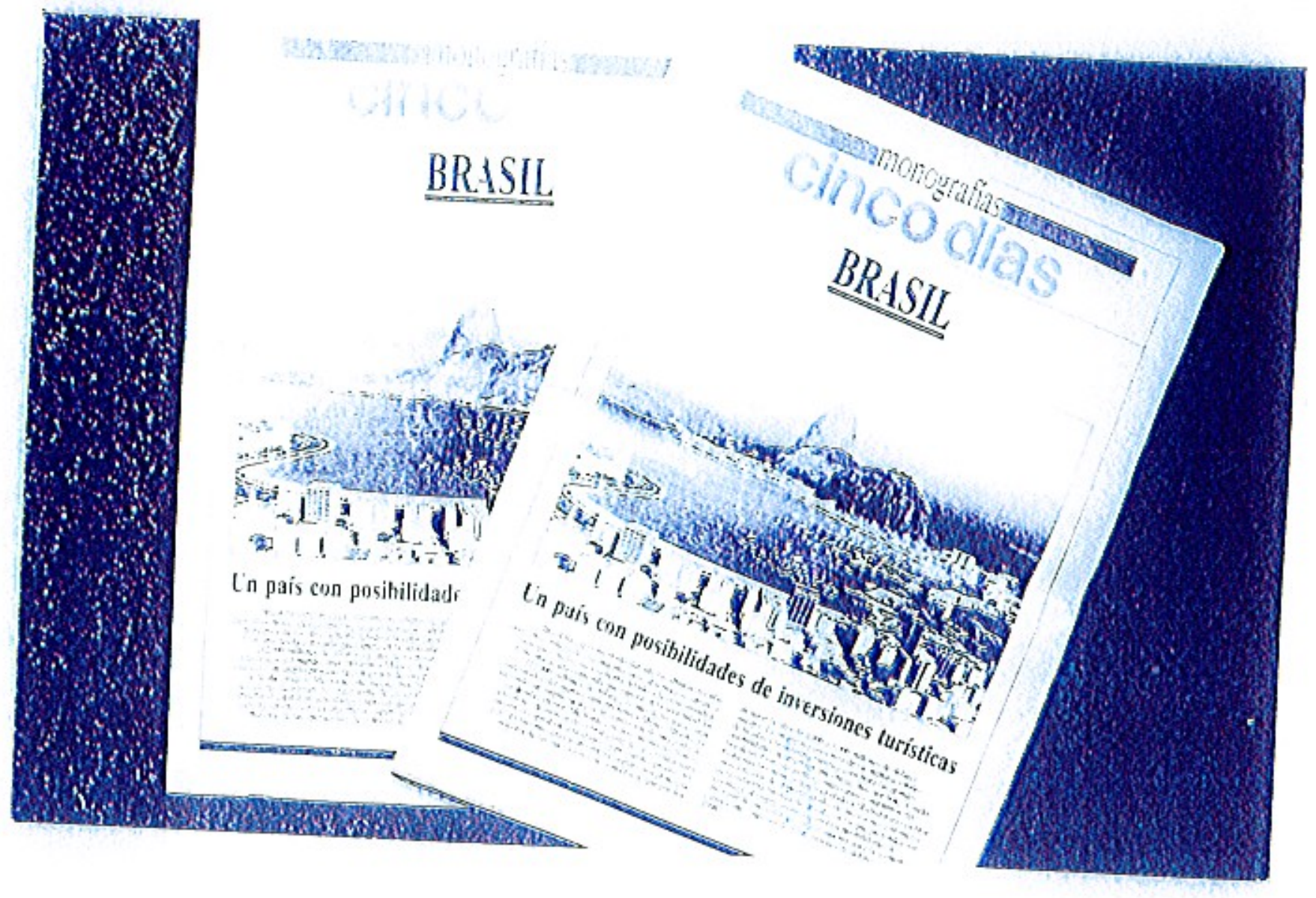

SUPLEMENTO DO DIÁRIO ESPANHOL

"CINCO DIAS" SOBRE AS VANTAGENS DE INVESTIR NO TURISMO DO BRASIL 


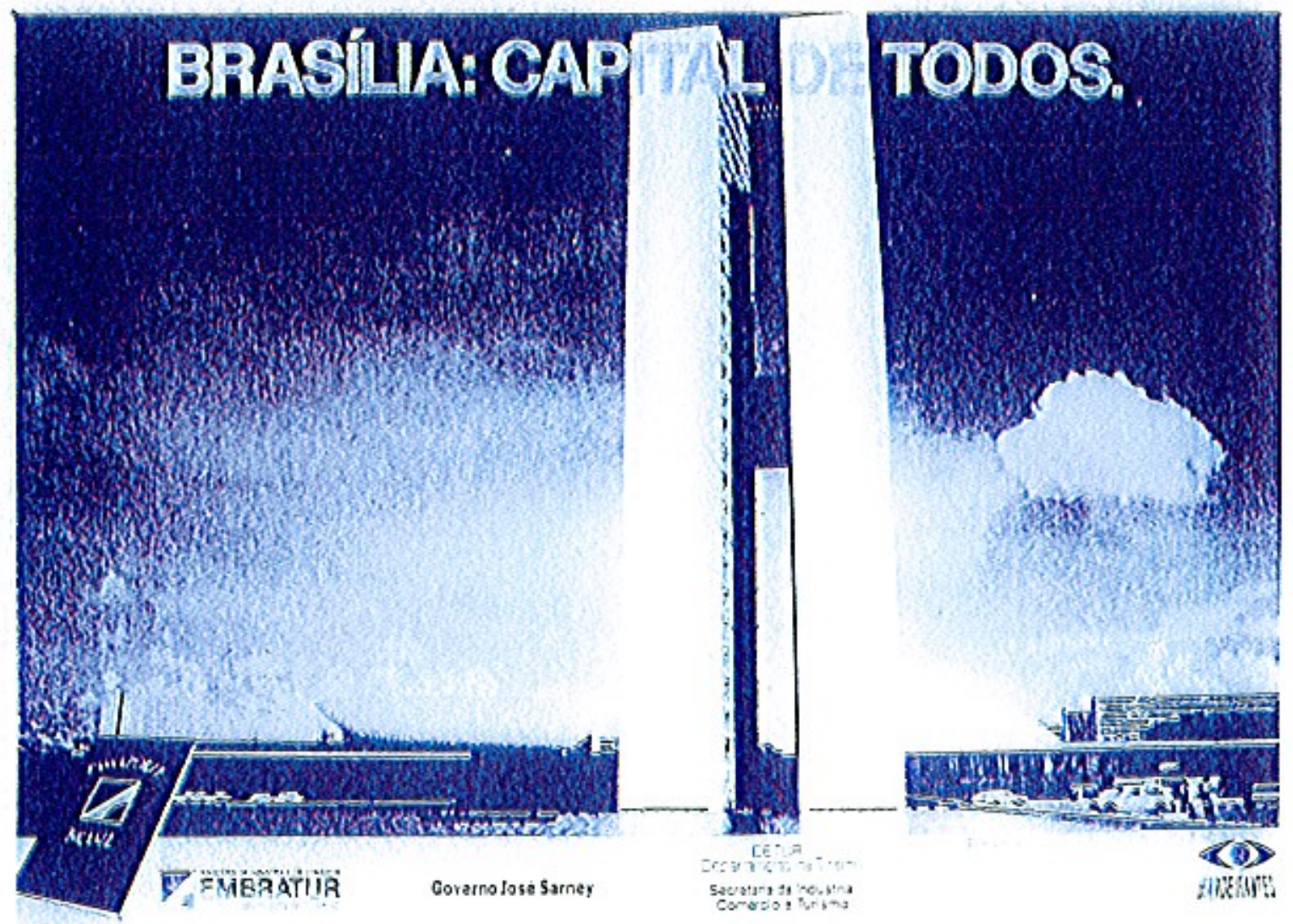

POSTER CAMPANHA

"BRASILIA: CAPITAL DE TODOS" 


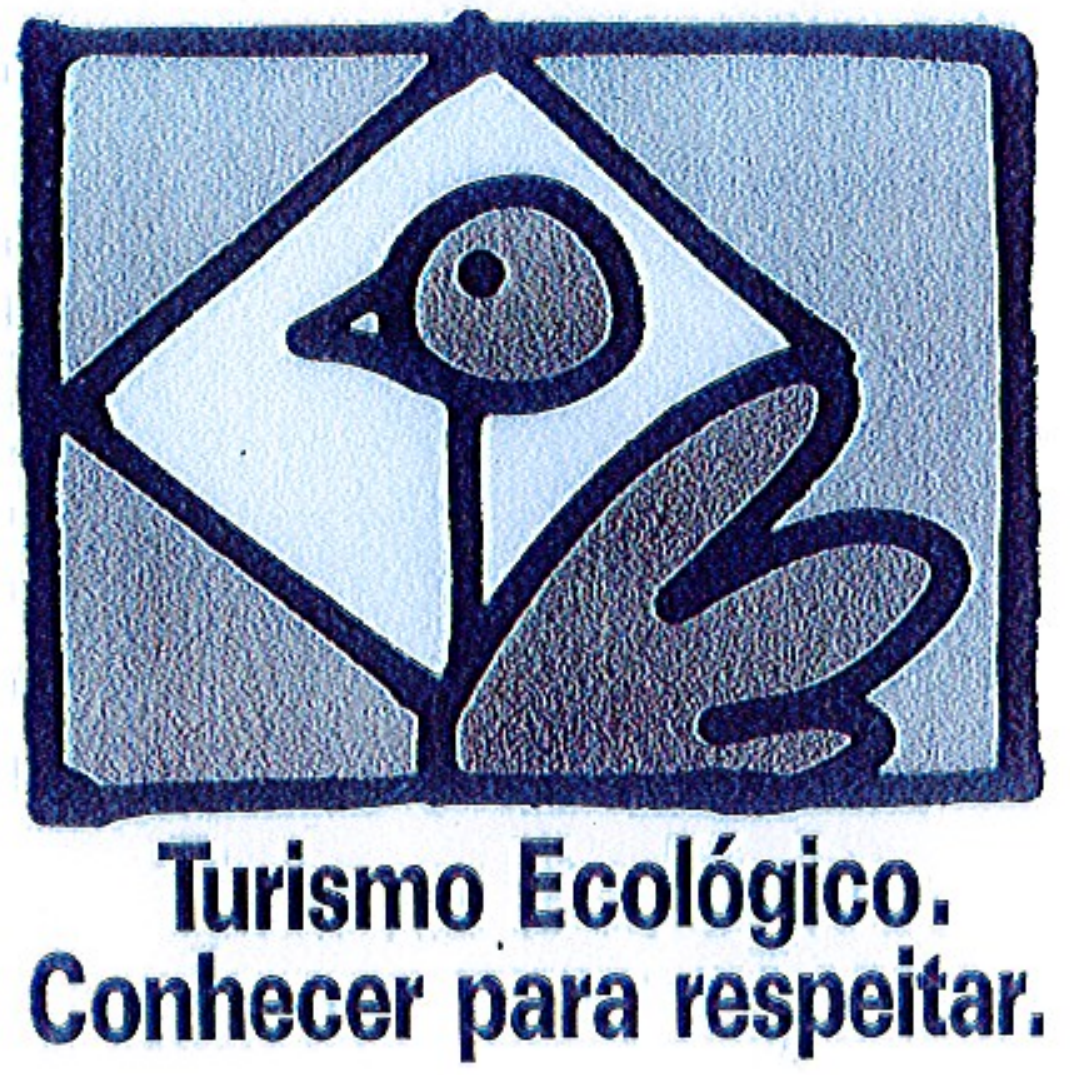

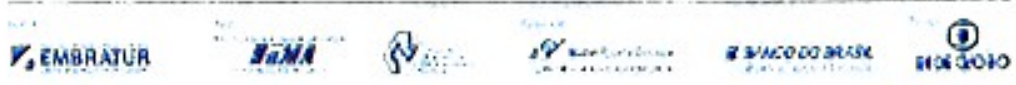




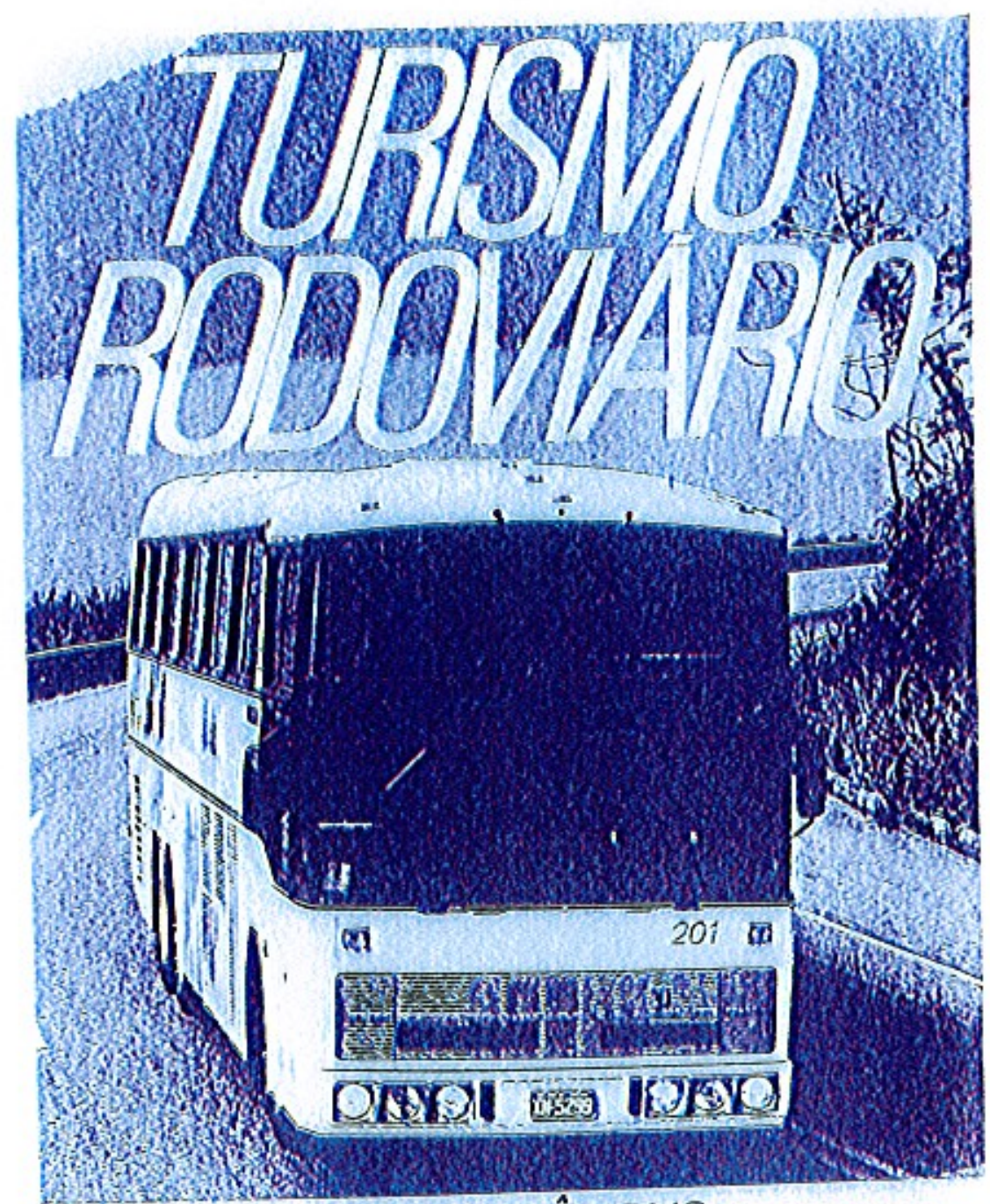

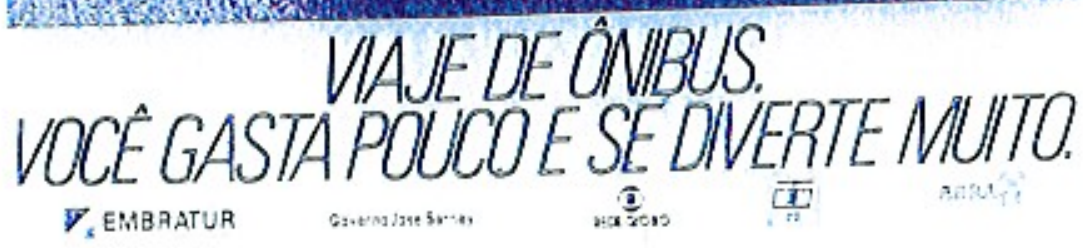

POSTER DA CAMPANHA TURISMO RODOVIARIO

EMBRATUR 


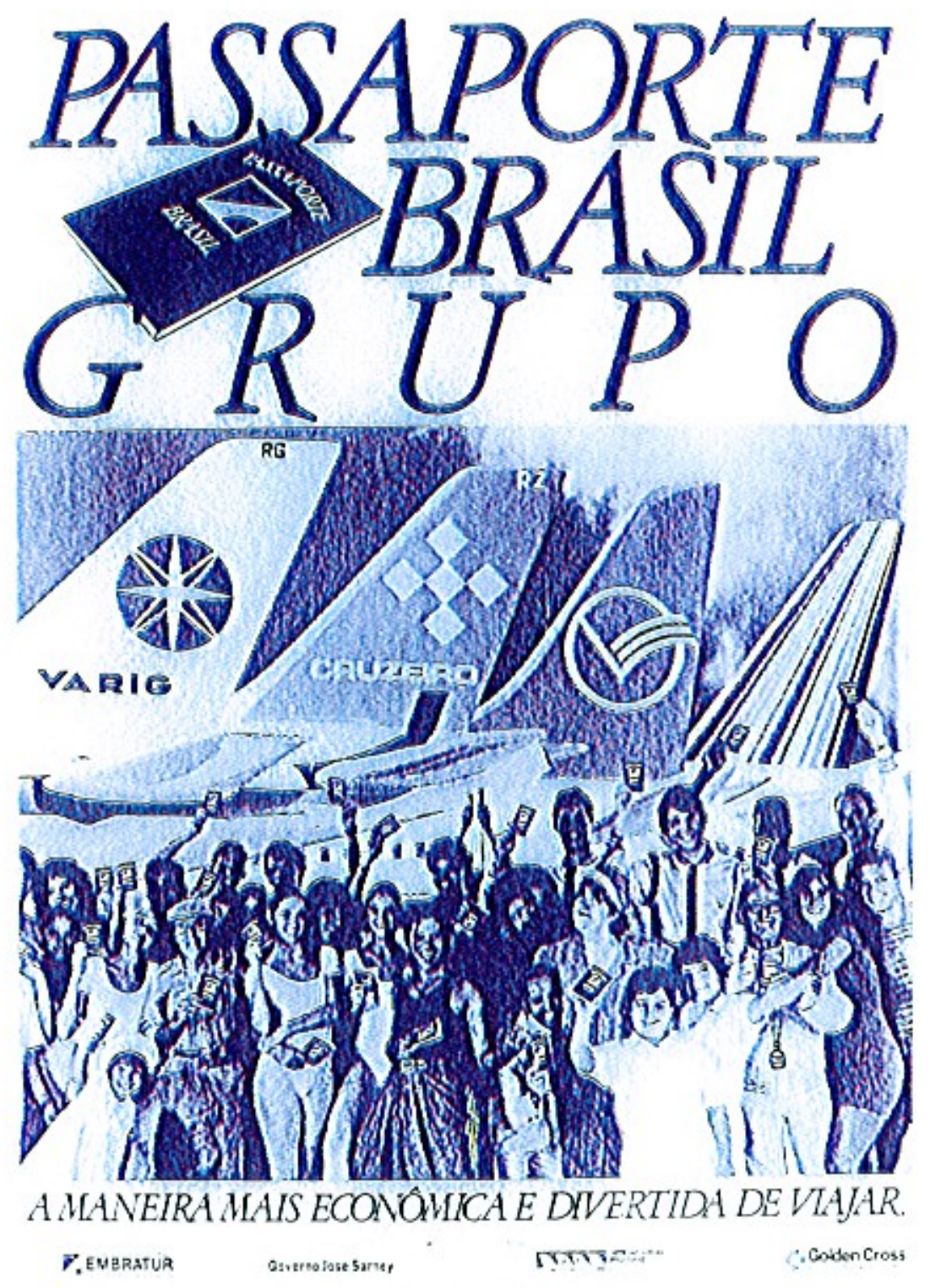

POSTER DO PASSAPORTE BRASIL GRUPO 


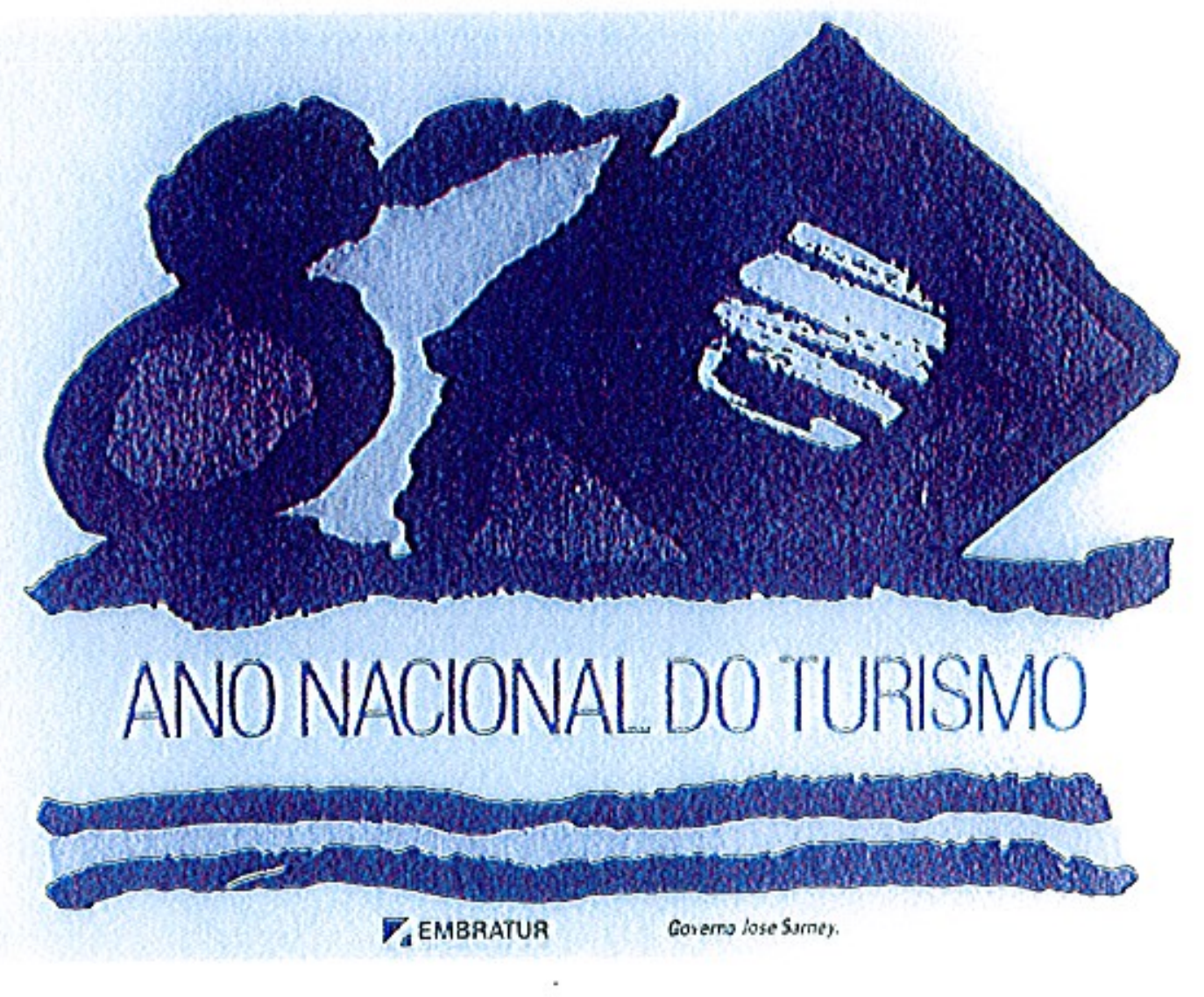

LOGOTIPO 87 - ANO NACIONAL DO TURISNO

EMBRATUR 

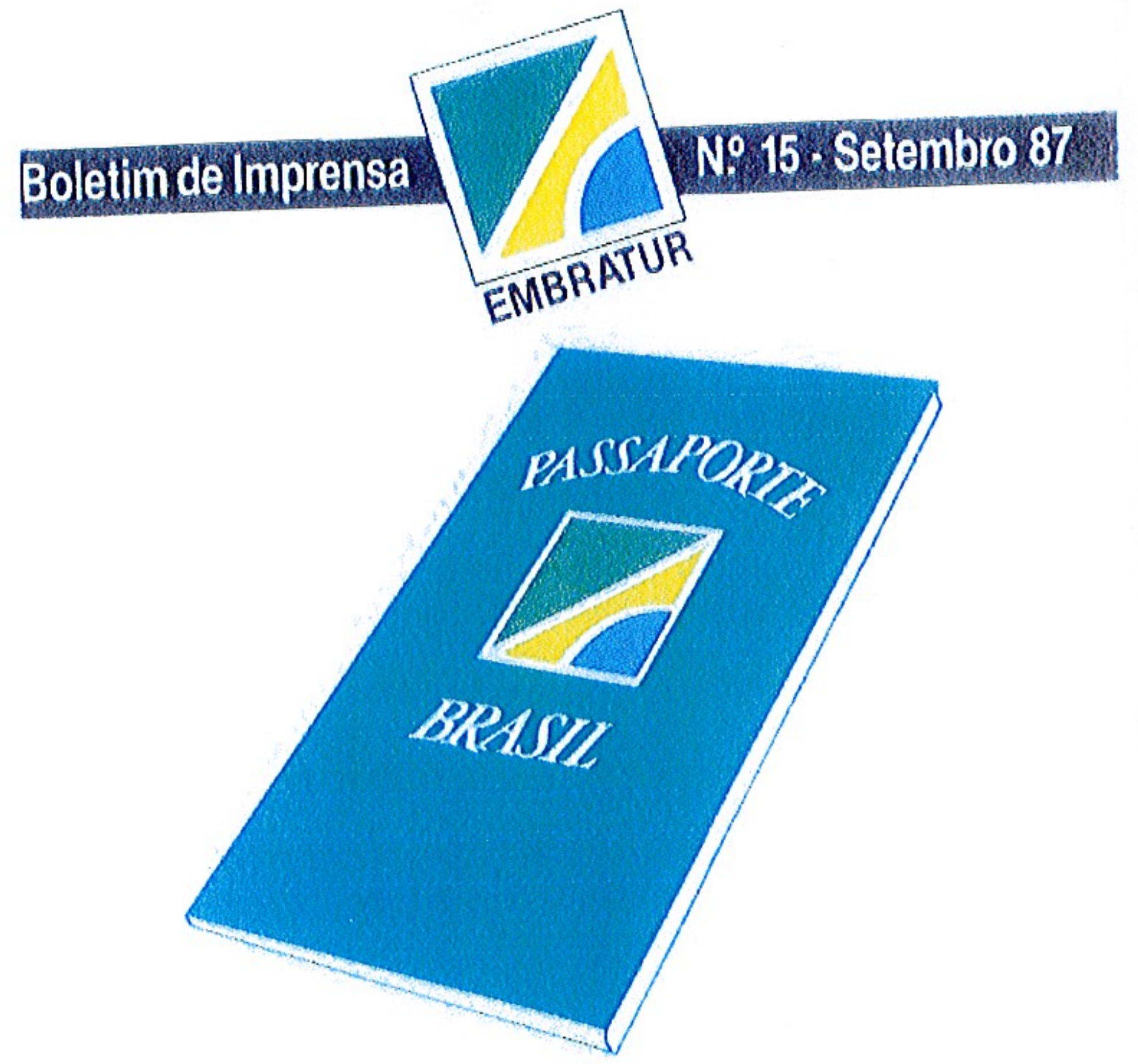

Un ano de sucesso

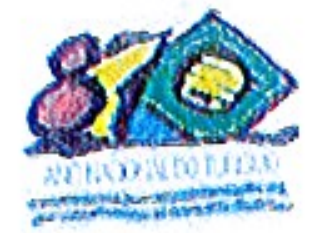




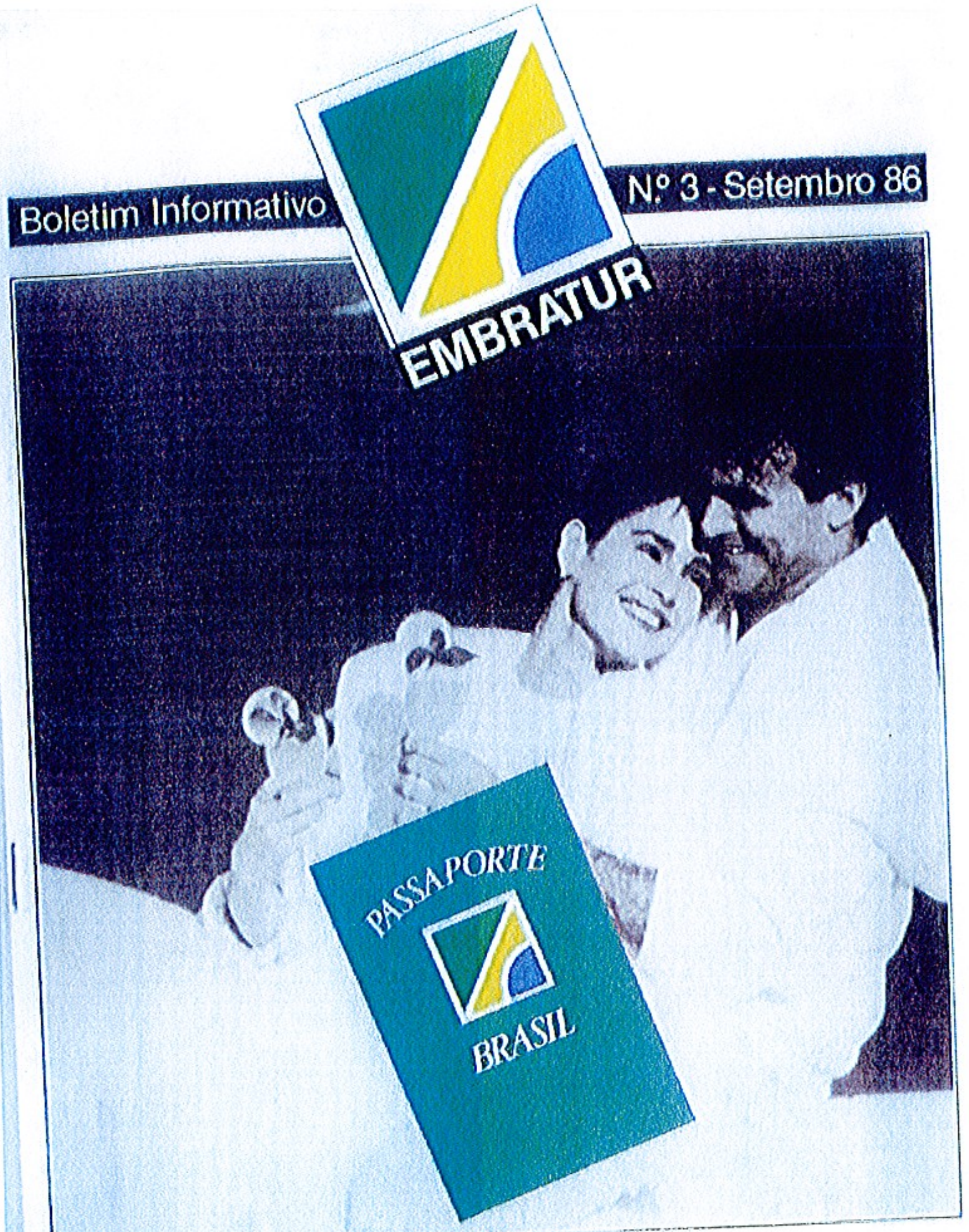




\section{Boletim de lmprensa}

\section{No11-Maio87}

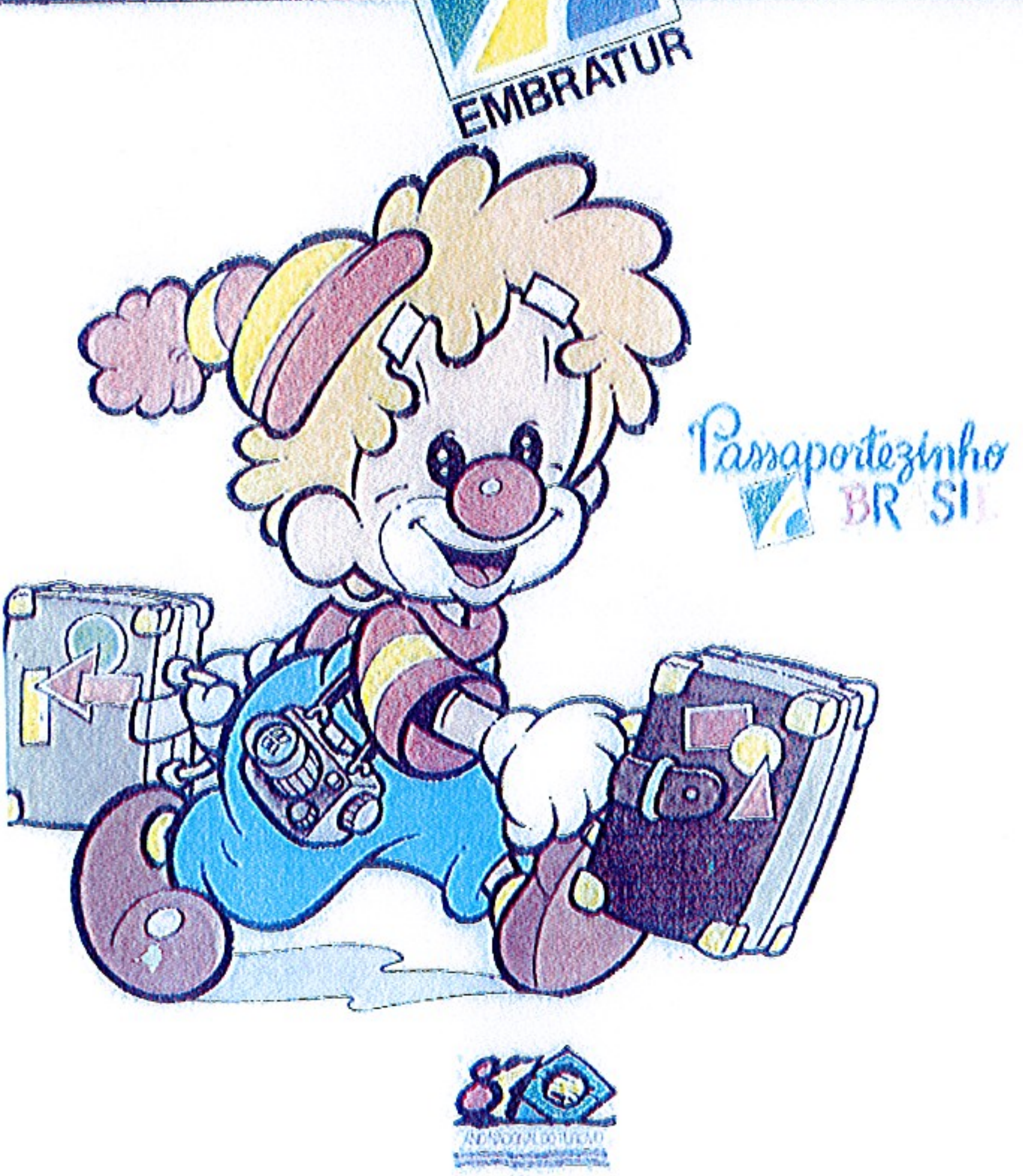


ANEXO V

Publicação da EMBRATUR de 1969 


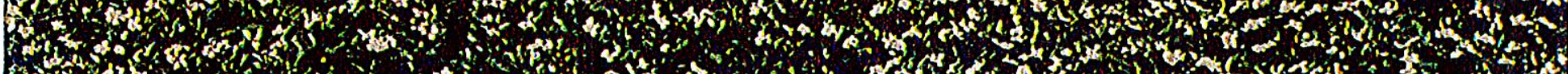

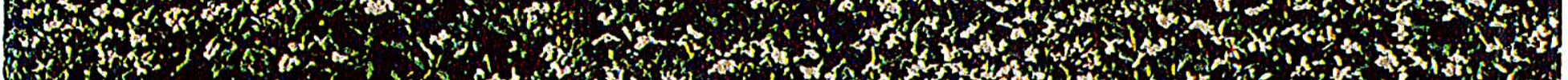

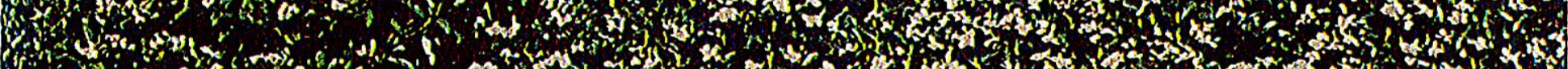

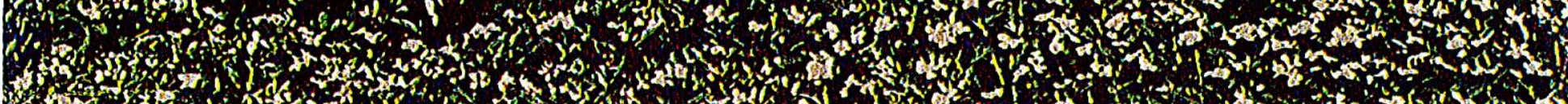

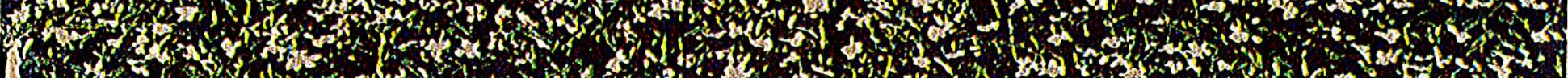

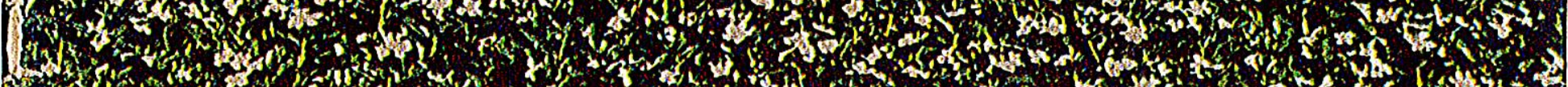

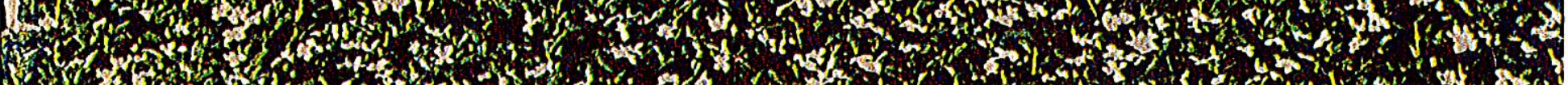
2. (4)

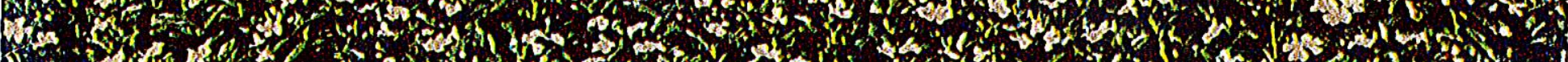

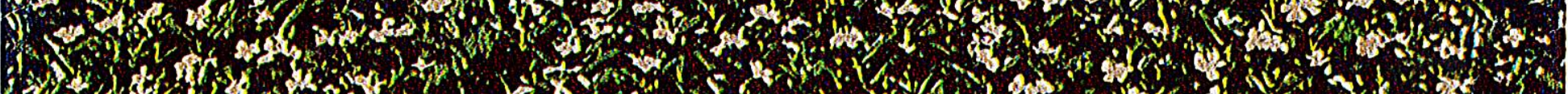

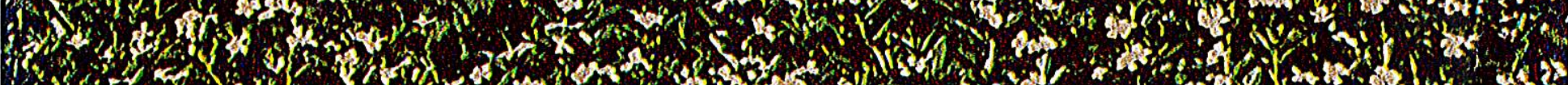

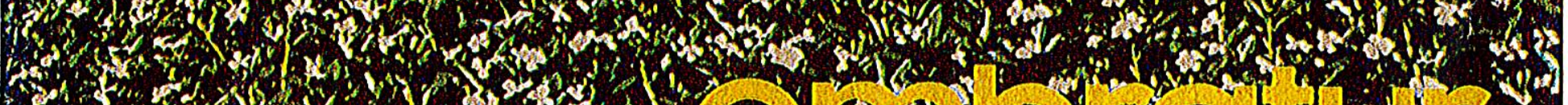

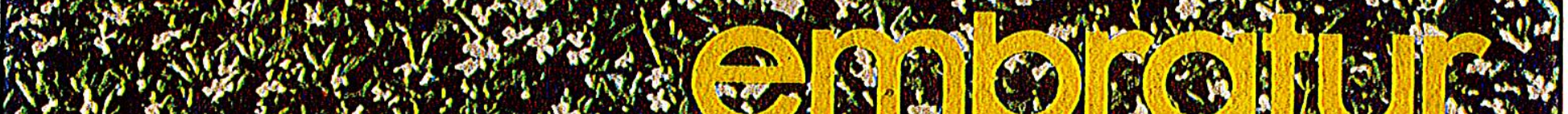

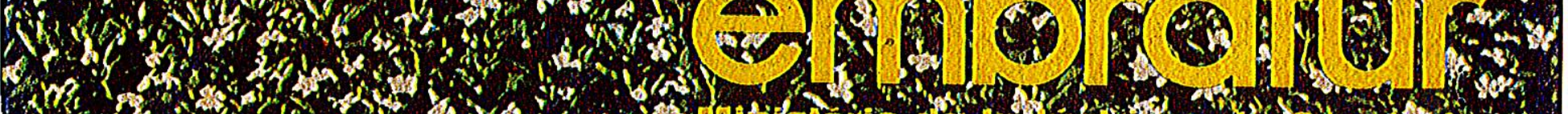

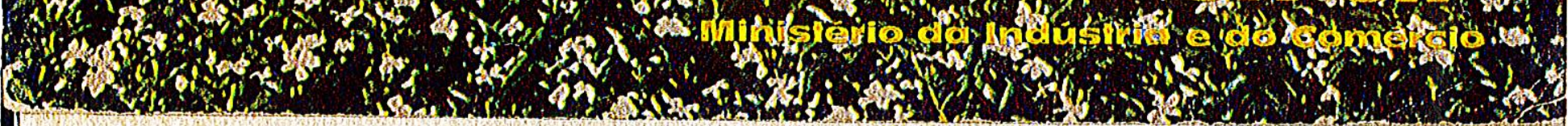


-

r. (us)

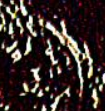
年,

W

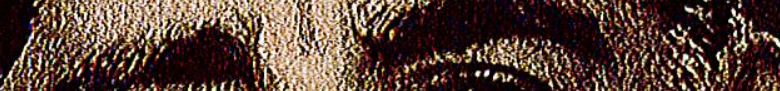

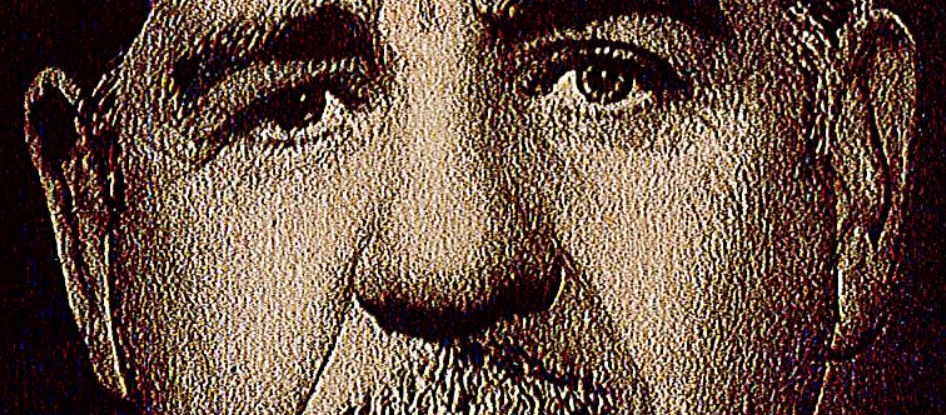

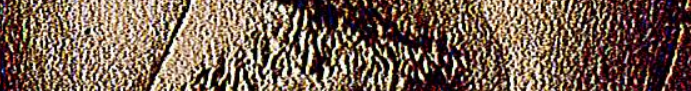

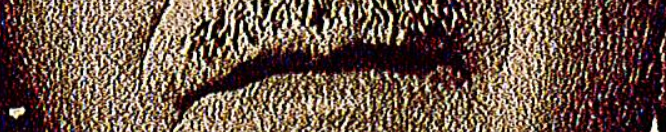
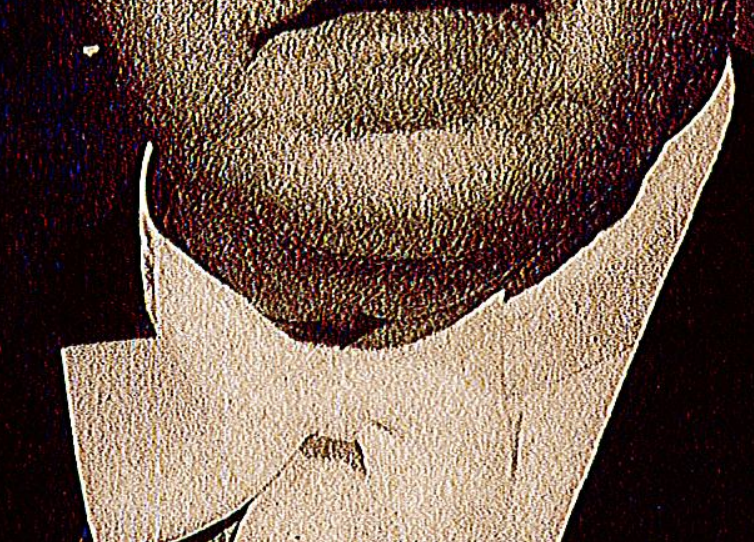

M.t.

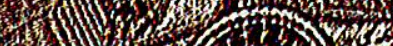

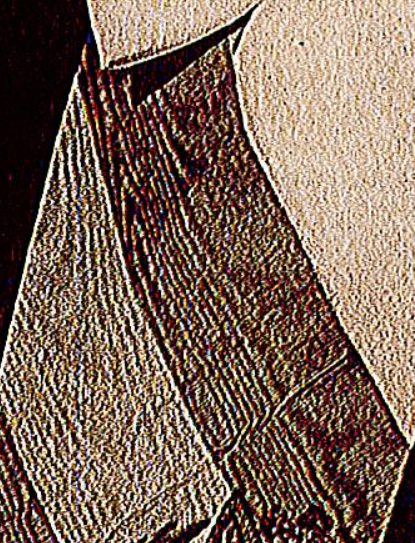




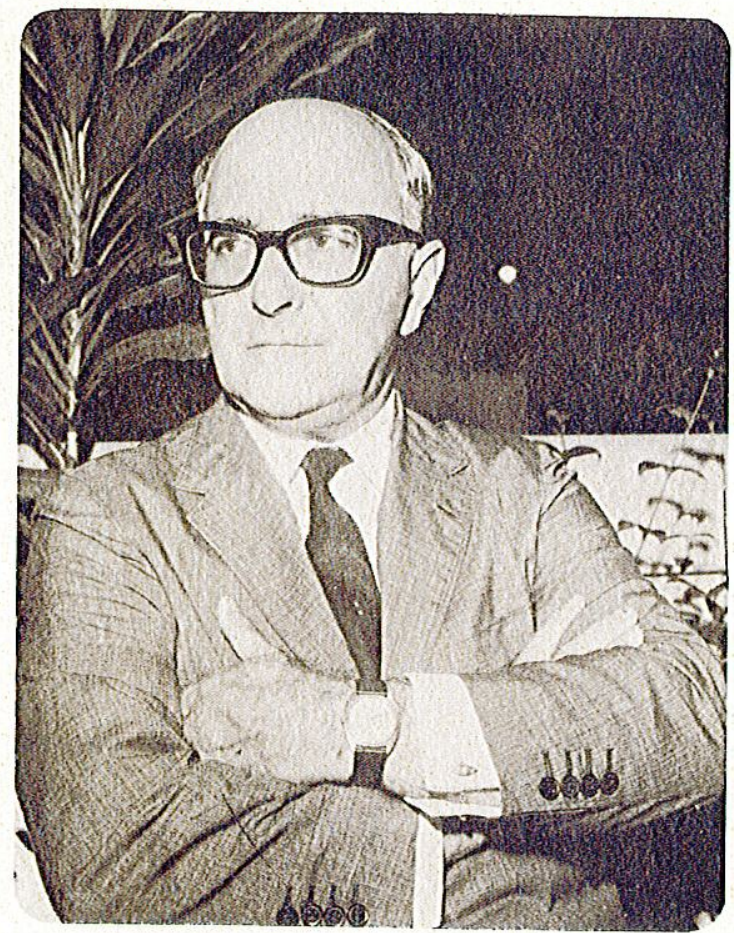

4 reunião do Fundo Monetário Internacional, que ora se realiza no Rio de Janeiro, representa, por si mesma, honrosa deferência concedida ao Brasil pelo importante organismo que regula e fiscaliza as finanças da comunidade de nações que o integram. Principalmente tendo-se em vista a natureza e o alcance das decisões a serem aqui tomadas, com profundas repercussões no imediato futuro do mundo ocidental.

Ao apresentar aos seus ilustres delegados as cordiais boas-vindas do Ministério da Indústria e do Comércio, é com vivo prazer que lhes ofereço, através da EMBRATUR, um dos órgãos do Ministério que dirijo, êste álbum que procura retratar, sintèticamente, a gigantesca nação que se orgulha de hospedá-los.

Faço-o na certeza de que estas imagens, na variedade de seus aspectos e na singularidade de seus contrastes, robustecerão ainda mais o aprêço e a confiança que têm demonstrado pelo Brasil - país que a par de grandes cidades cosmopolitas possui também imensas reservas territoriais inteiramente virgens, e que já iniciou resolutamente a sua caminhada para a industrialização e o desenvolvimento.

Y holding the meeting of the International Monetary Fund in Rio de Janeiro, this important agency which establishes the policies and coordinates the financial systems of member nations is paying a great compliment to Brazil.

It is particularly significant in view of the importance and meaning of the decisions to be taken here and their immediate repercussions on Western civilization.

Greeting the honorable delegates on behalf of the Ministry of Industry and Trade, I take pleasure in offering this album, through EMBRATUR, one of the agencies of this Ministry. In it we have tried to give a true picture of this country so proud to welcome you.

I do so in the hopes that these pictures, showing the variety and contrasts of Brazil, will help to increase the friendship and confidence you have shown in us, a country of vast virgin lands as well as great cosmopolitan cities, a new country firmly on the road to industrialization and development. 


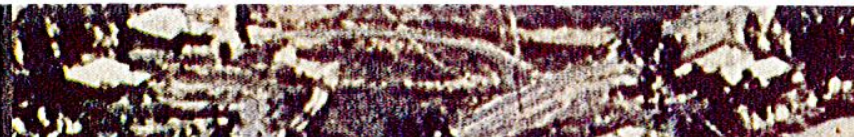

Q

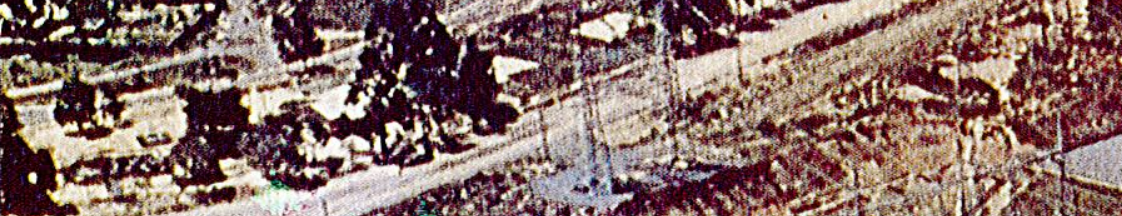
E-jus

\section{2}

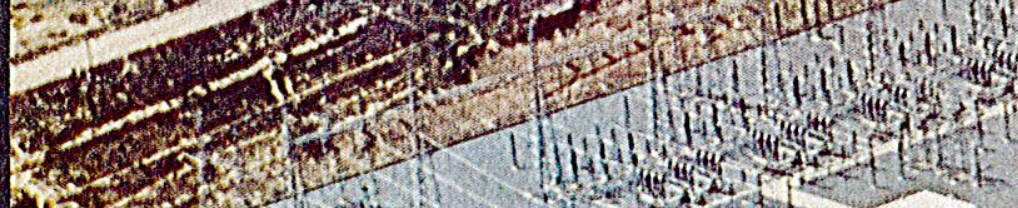

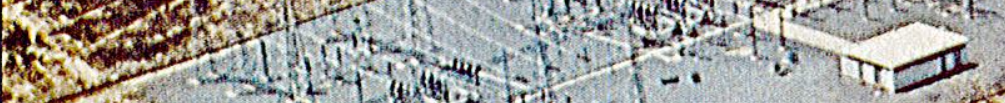

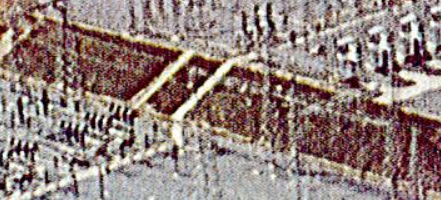

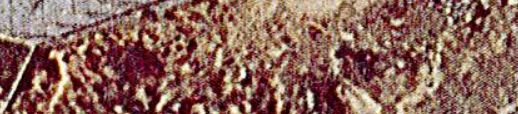

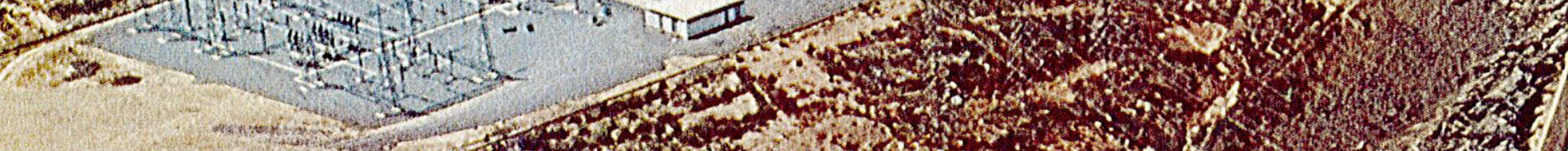

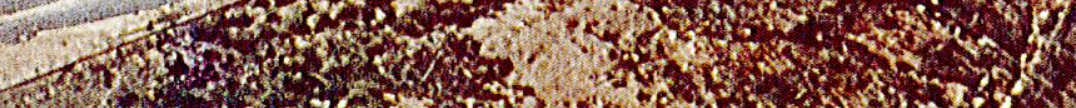
W.

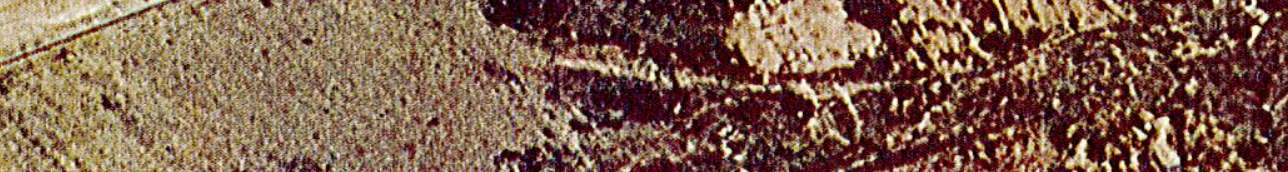
S.

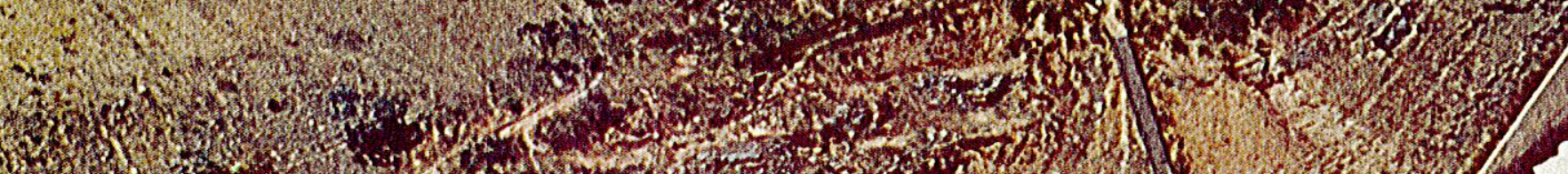

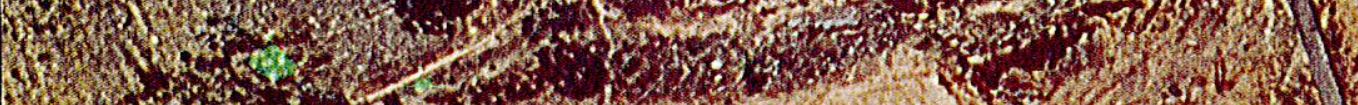

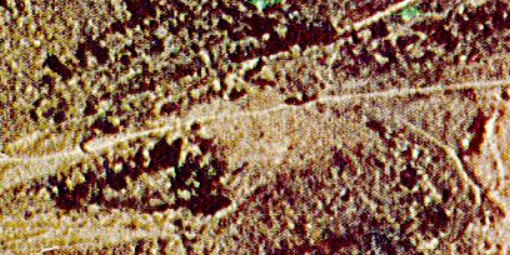

1. W.

why

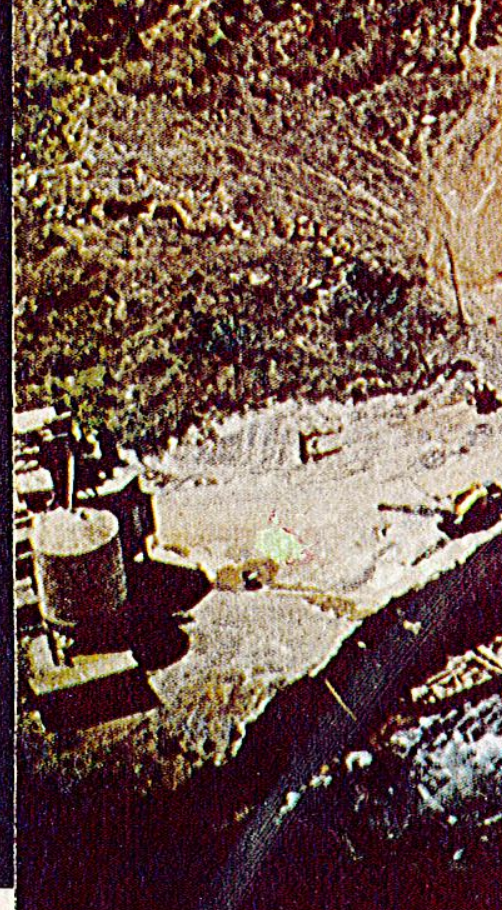

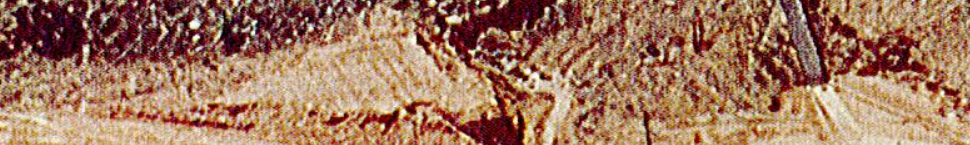




\section{Sempre novas obras/New mon}
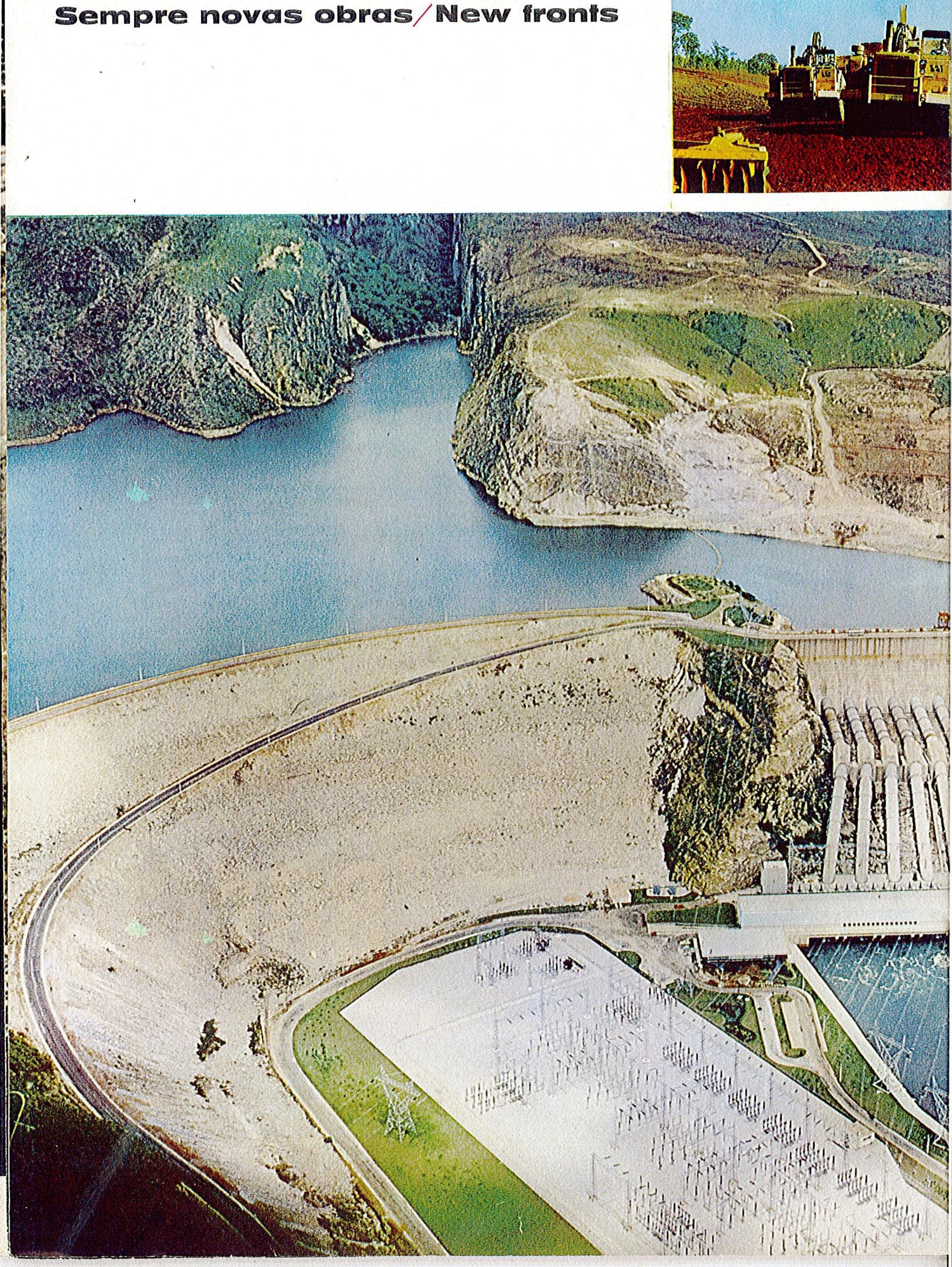
ROVAS frentes são abertas (à esquerda), ao mesmo tempo $\mathrm{cm}$ que se completa a extraordinária hidrelétrica de Furnas (abaixo), com capacidade de $1.200 .000 \mathrm{kw}$. Todos os prazos de construção das grandes barragens hidrelétricas brasileiras são fielmente cumpridos.

NEW fronts are opened (left) while the 1.200.000-kilowatt Furnas plant reaches completion.

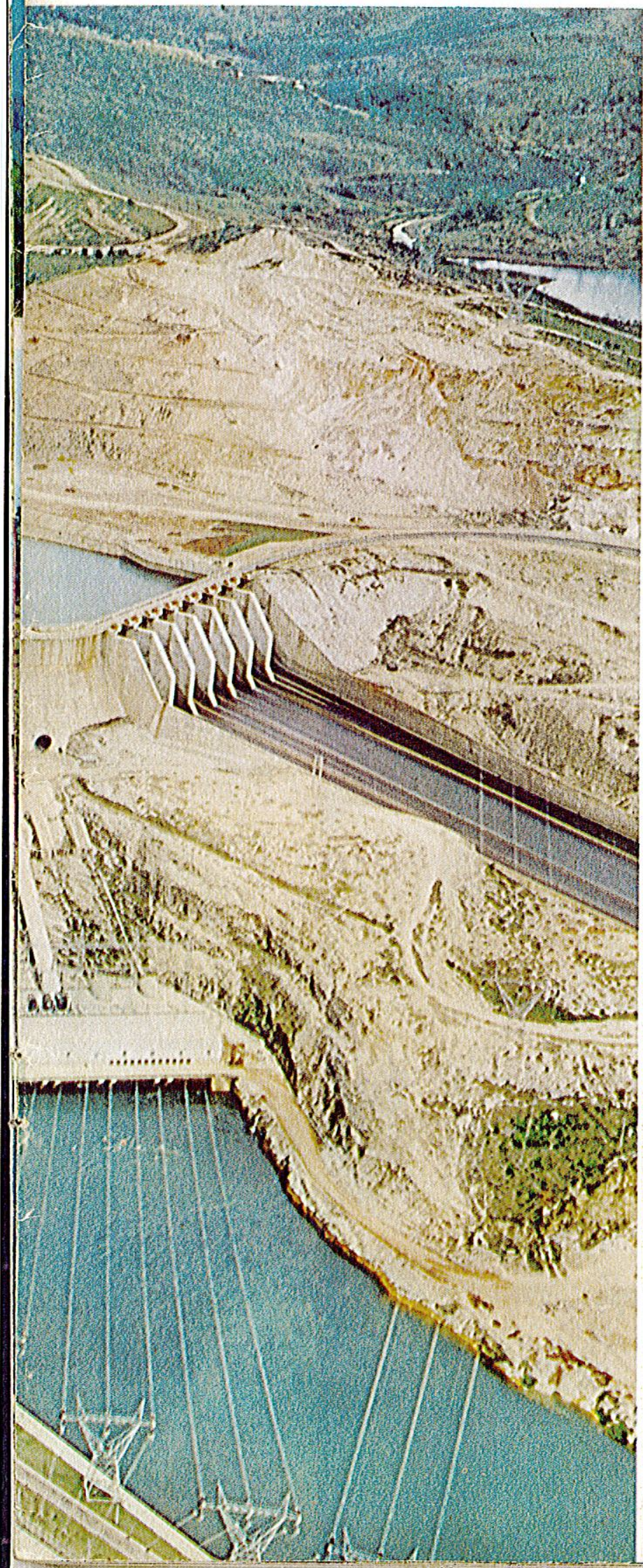

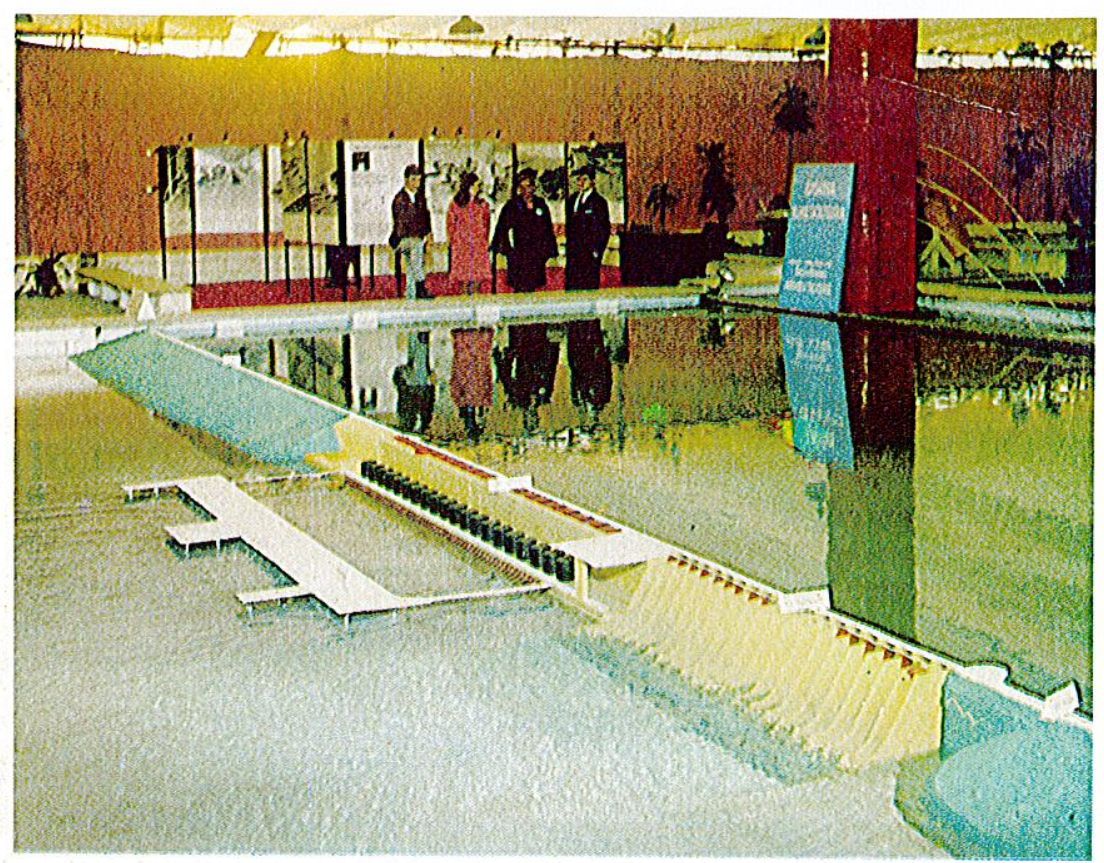

\begin{tabular}{l|l} 
Maquete de liha Solteira que, com & $\begin{array}{l}\text { Model of the Ilha Solteira hydro-elec- } \\
\text { Jupiá, produzirá } 4.600 .000 \mathrm{kw} \text {, levando }\end{array}$
\end{tabular} o progresso a uma importante região. Jupia Plant, will produce $4.600 .000 \mathrm{kw}$.

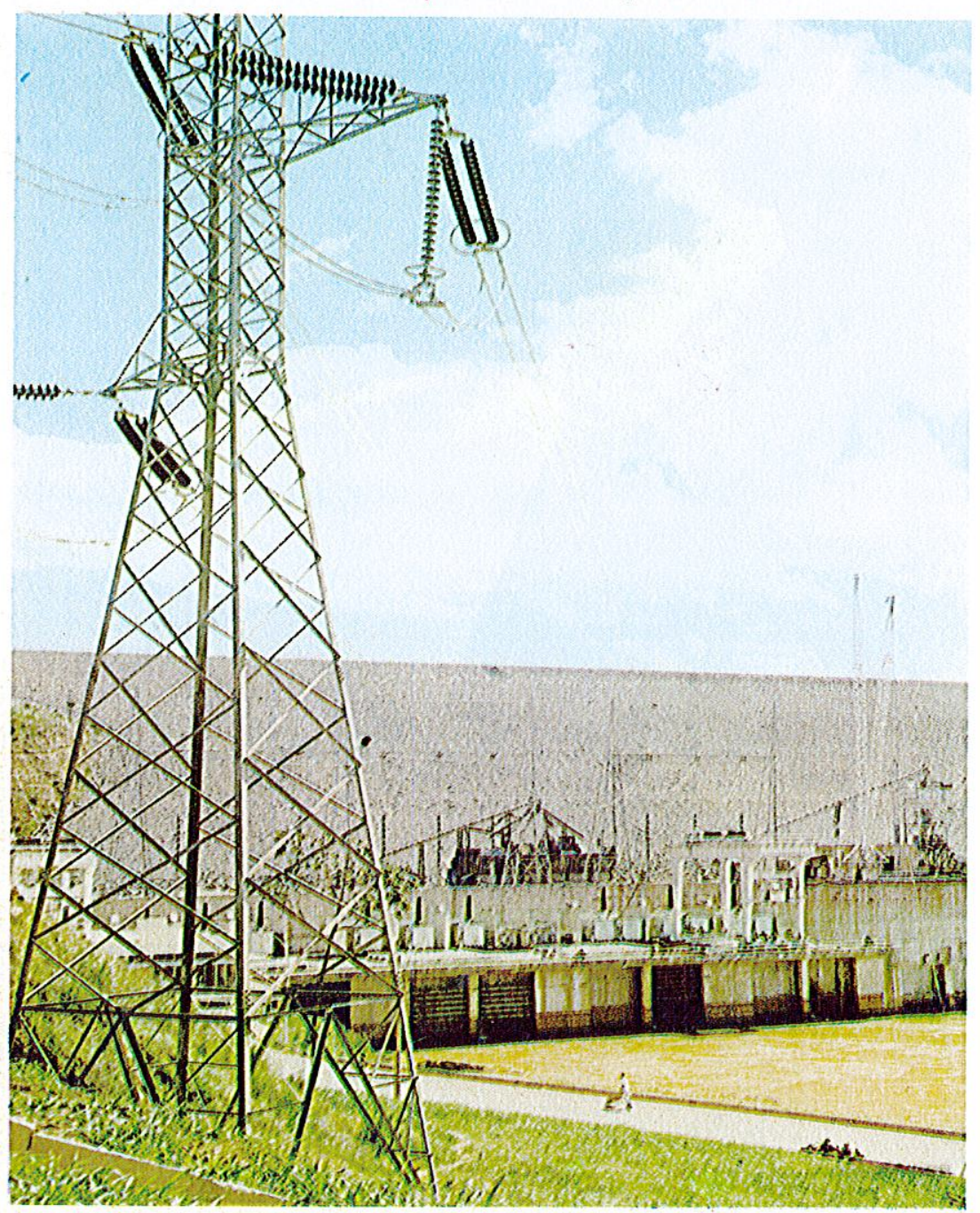

Com as novas obras em andamento, 0 potencial energético do Brasil será duplicado, de seis para doze milhões de

With the new works now undier way, Brazil's electric power potential will be doubled - from six to 12 million $\mathrm{kw}-$ by 1970 , bringing more progress to all regions of the country. 
- espeláculo de Urubupungá / New look for a river

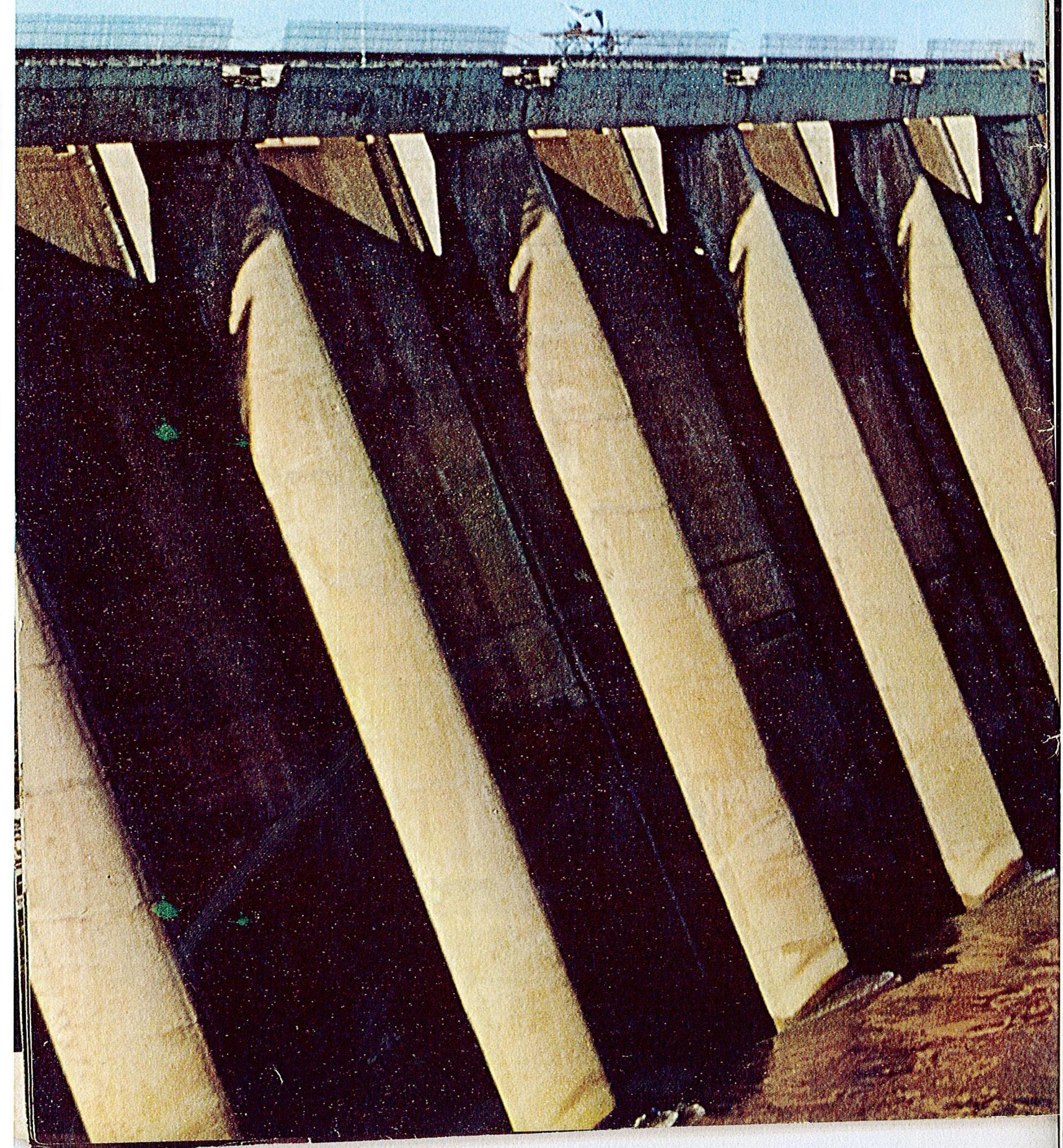




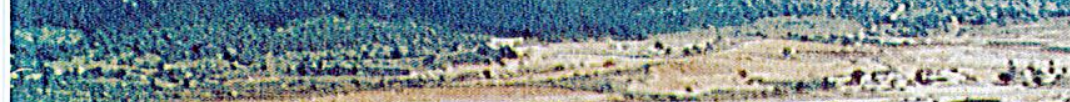

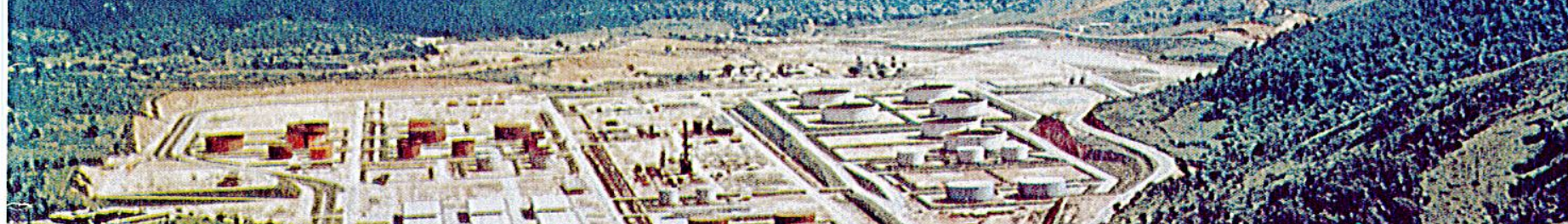

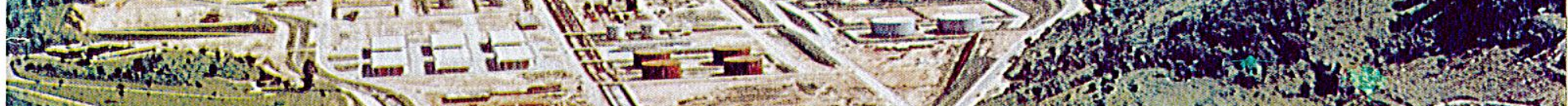

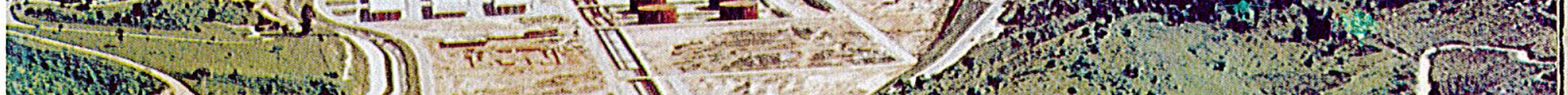

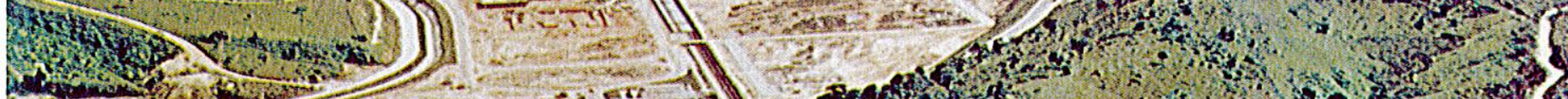

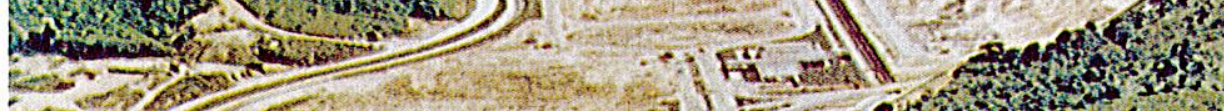
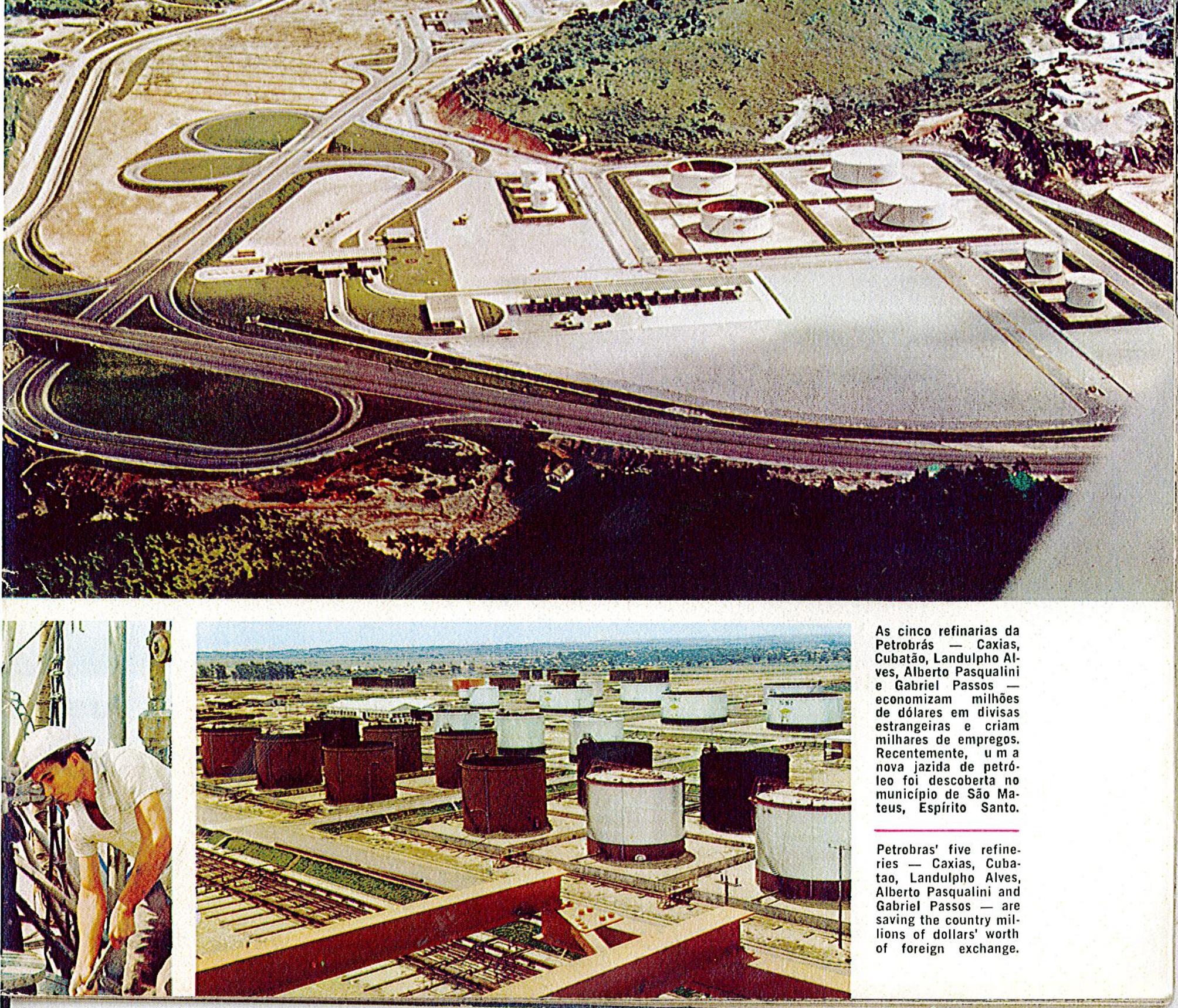

As cinco refinarias da Petrobrás - Caxias Cubatão, Landulpho Alves, Alberto Pasqualin e Gabriel Passos de dólares em divis estrangeiras e criam milhares de empregos. Recentemente $\mathrm{m}$ nova jazida de petró leo foi descoberta no municipio de São teus, Espírito Santo.

Petrobras' five refine ries - Caxias, Cuba tao, Landulpho Alves. Alberto Pasqualini and Gabriel Passos - are saving the country millions of dollars' worth of foreign exchange. 



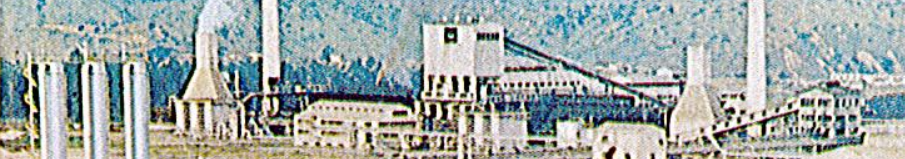

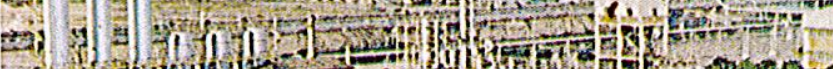

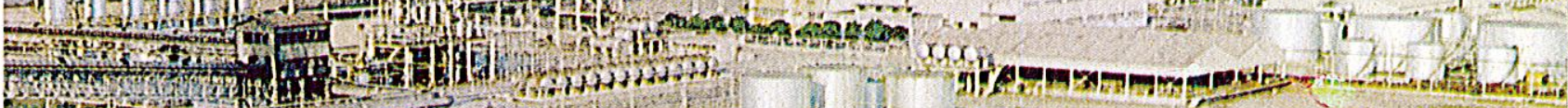

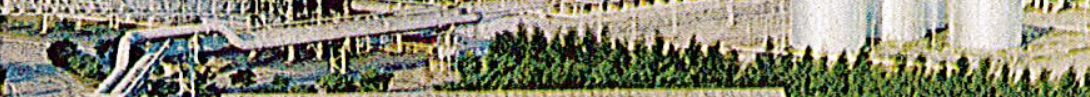

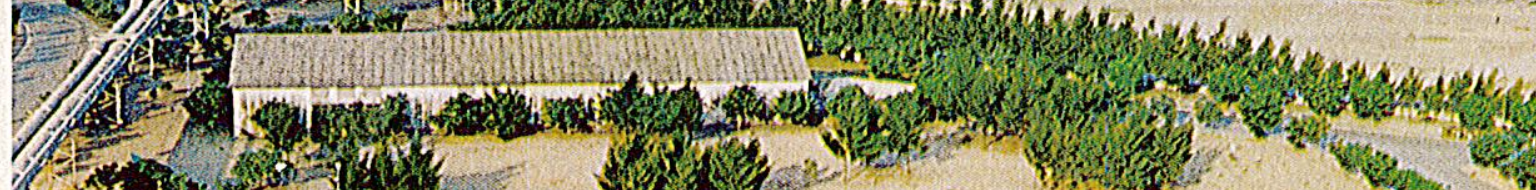

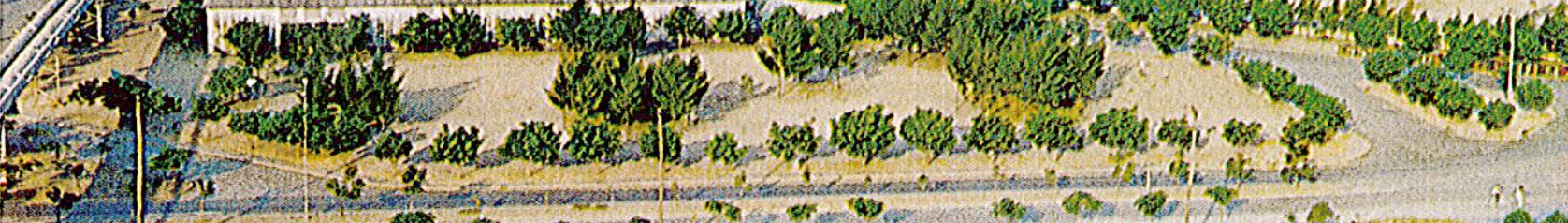
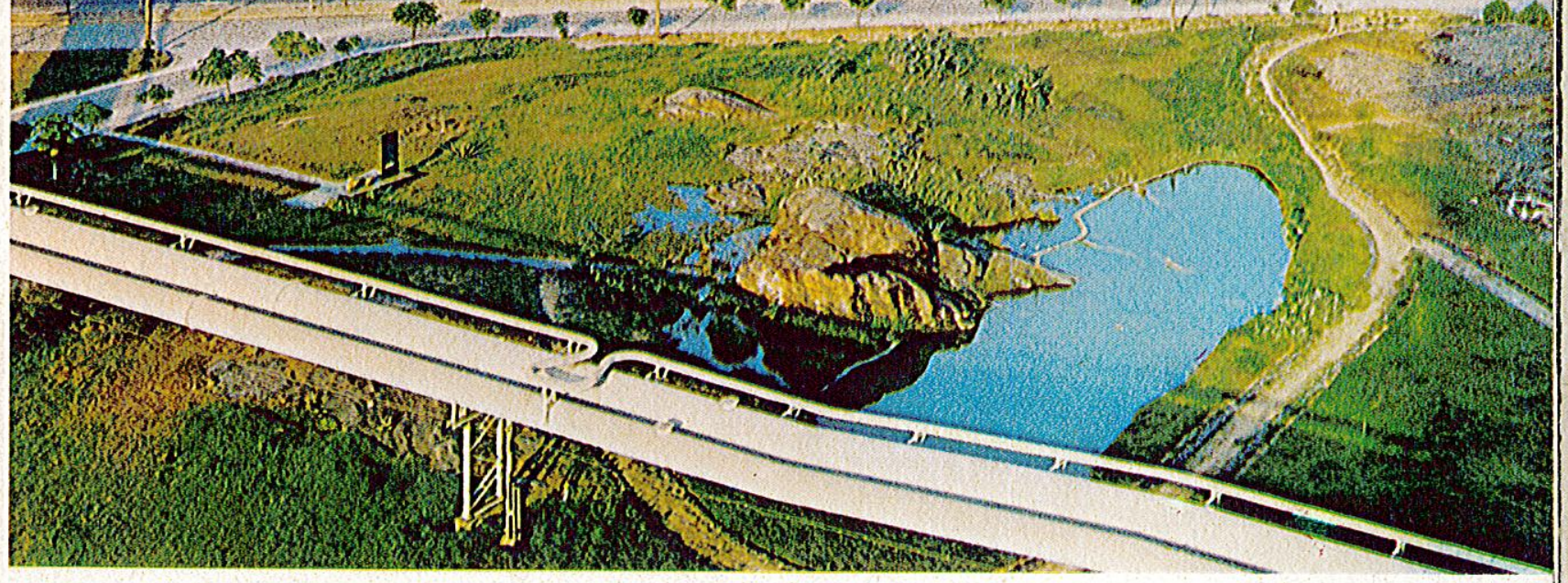

щ1

Siderurgia, mineração e carvão contam com a maior soma de investimentos do país: 827 milhões de cruzeiros novos.

The largest Brazilian investment is in the steel industry, ore mining and coal: 827 million new cruzeiros last year.
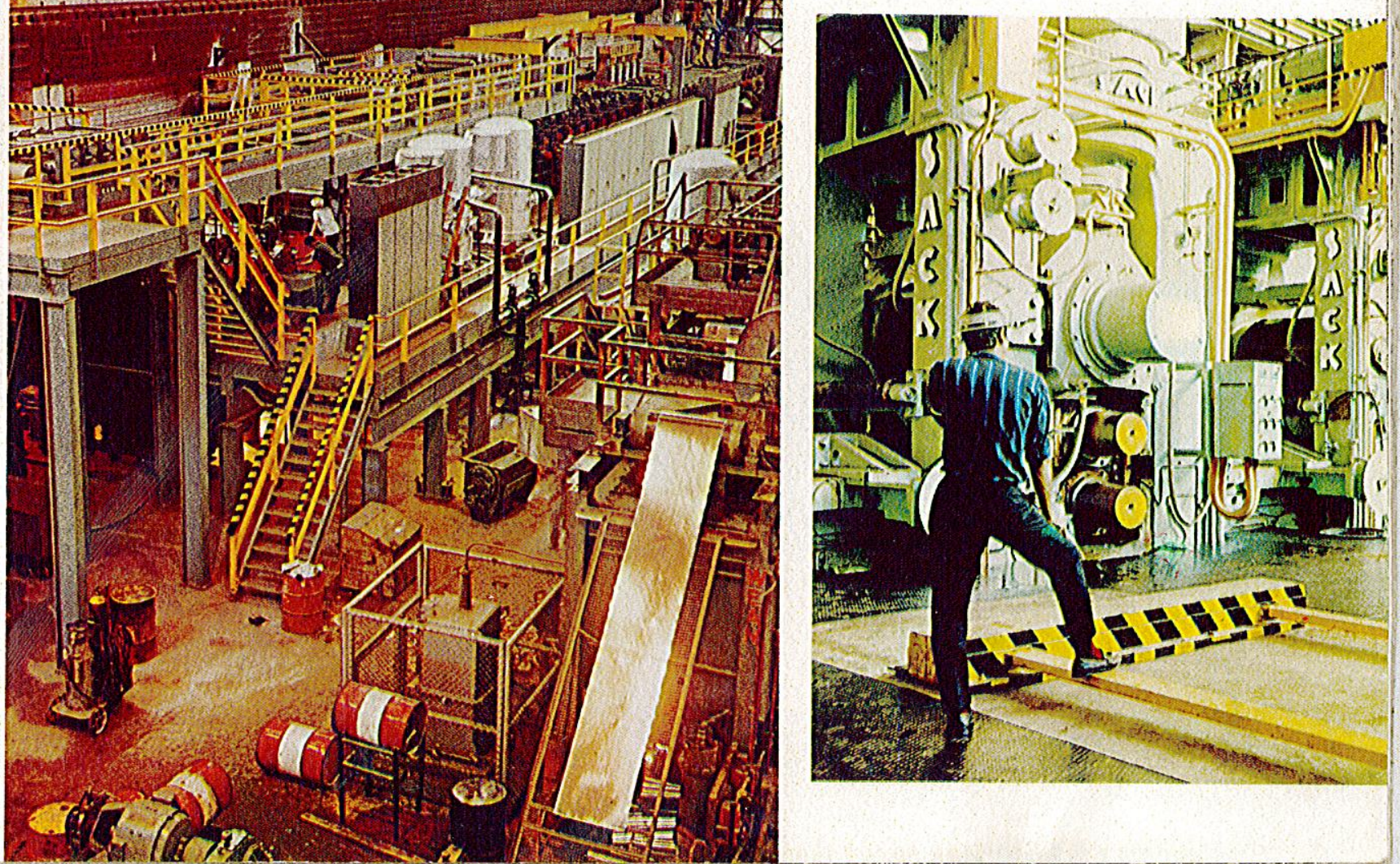


\section{As rodas do progresso / Wheels of progress}
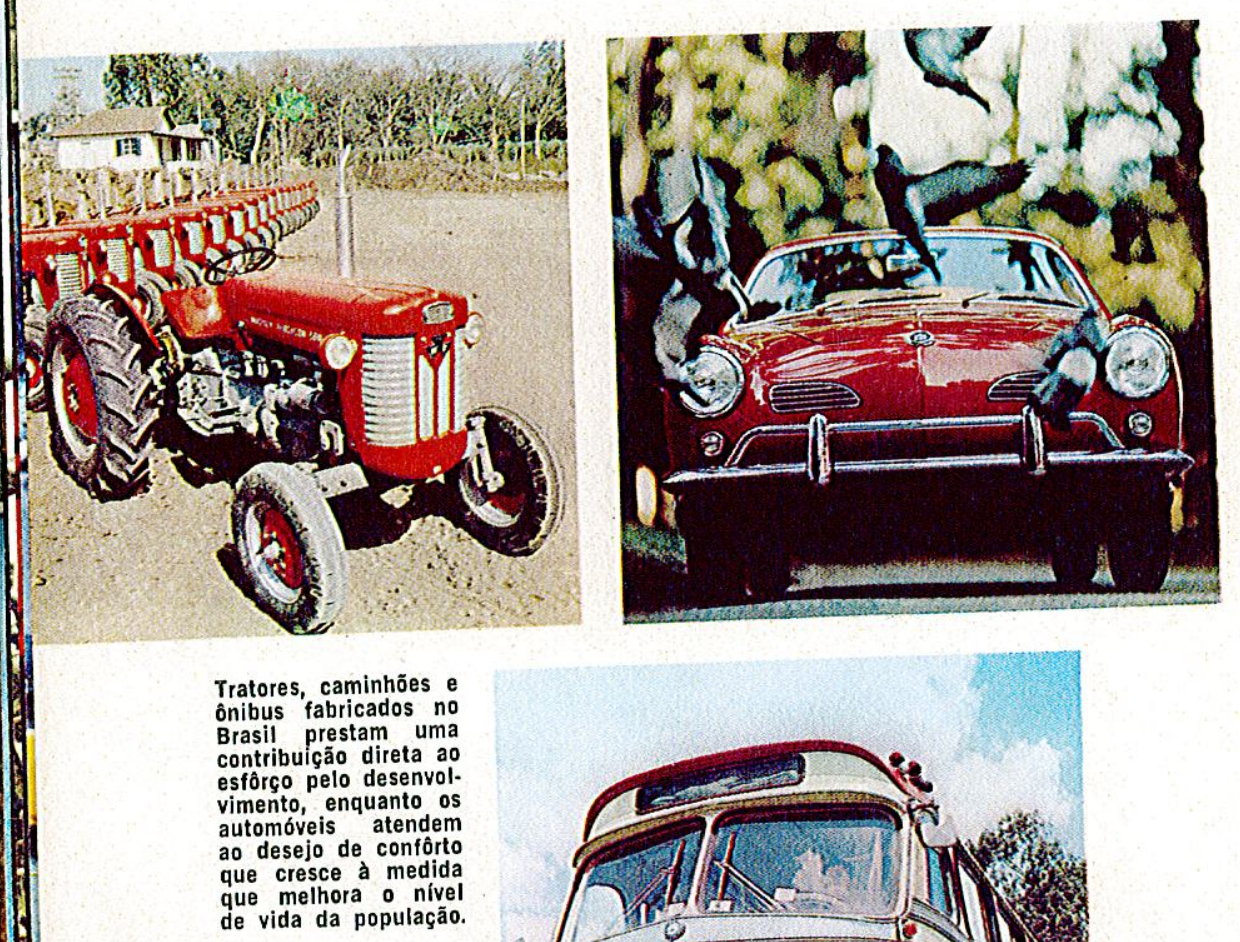

Tractors, trucks and buses made in Brazil contribute for our progress, while cars answer the earning for comfor which is in creasing as the livin standard of the popu. throug gets in proved tes of the country.
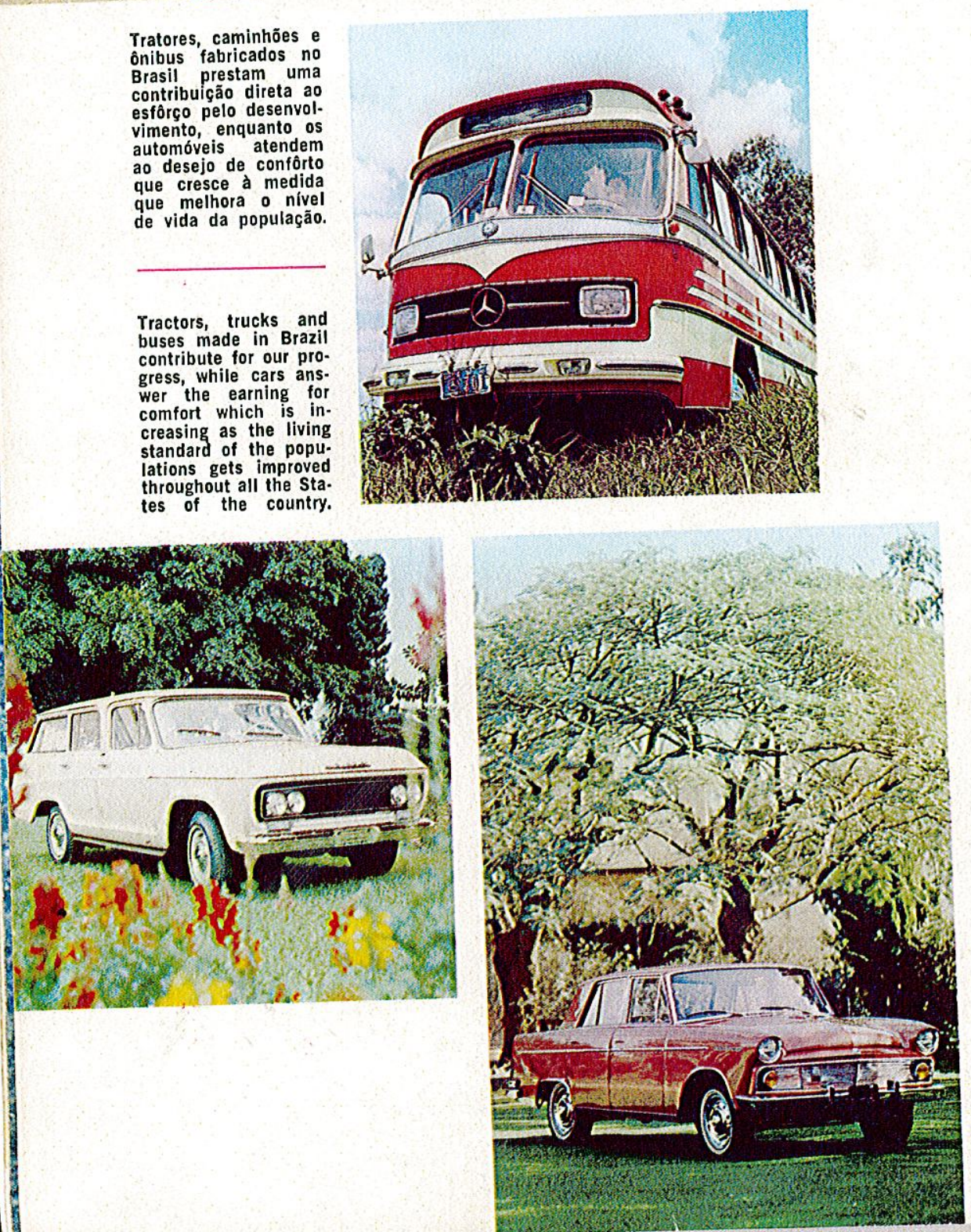

E o Brasil tivesse importado todos os veículos que foram produzidos no país teria gasto cêrca de cinco bilhões de dólares. Mas a economia de divisas é apenas um aspecto da contribuição prestada ao desenvolvimento brasileiro pela indústria automobilística. Outros aspectos são: um milhão de empregos, proporcionados pelas fábricas de veículos, de autopeças e matérias-primas e pelas rêdes de assistência e comercialização; mais de meio bilhão de cruzeiros novos pagos em impostos federais, estaduais e municipais; melhores salários aos operários, que, em média, ganham três vêzes o maior salário mínimo nacional; formação de especialistas e elevação do know-how. Até a agricultura é beneficiada pela indústria automobilística, que fabrica tratores para aumen tar sua produtividade. Hoje, as indústrias automobilísticas brasileiras também mantên eficientes equipes de proje tistas de diferentes veículos.

HAD Brazil imported the number of vehicles produced in the country, the bill would have been about five billion dollars. But the economy in foreign exchange is only one part of the automobile industry's contribution to the development of Brazil. Other contributions are: employment of one million people in the automobile factories themselves and in plants producing parts and primary materials, in maintenance shops and selling. The in dustry pays half a billion new cruzeiros in taxes, pays higher salaries to employees who on an average earn three times the minimum wage. The industry trains techncians and raises the level of know-how in the country. Agriculture is benefitted by tractors to increase productivity. The industry today even has its own designers.

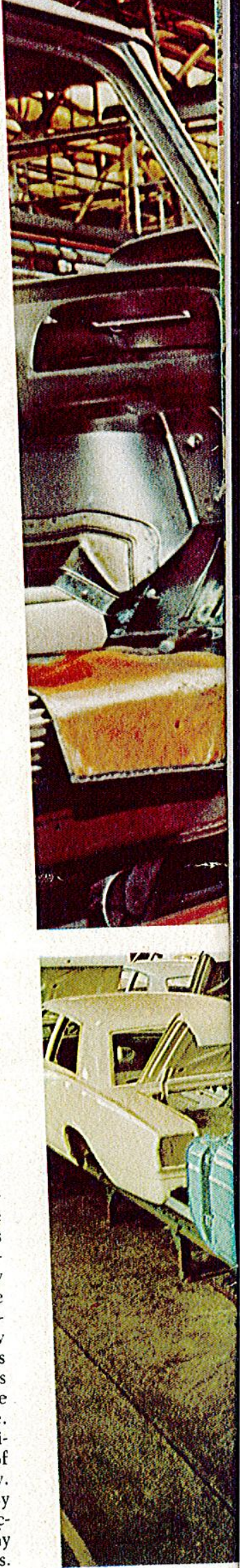


GRANDES emprêsas estrangeiras atenderam ao chamado brasileiro e instalaram aqui suas fábricas, demonstrando confiança nos destinos do país. Hoje, êsses investimentos são retribuídos com lucros compensadores. E o Brasil também ganha: do preço de um carro vendido ao público por 10 mil cruzeiros novos, 4.385 cruzeiros vão para os cofres municipais, estaduais e federais, ou seja, quase $44 \%$.
5 OME of the world's best known au tomobile manufacturers took advantage of the exceptional conditions offered by the Brazilian Government to instal factories here. Their faith in Brazil's future has been amply rewarded by compensating profits. But Brazil also gains: 44 per cent of the retail price of an automobile goes into the municipal, state and federal coffers in the form of taxes which grow every year.
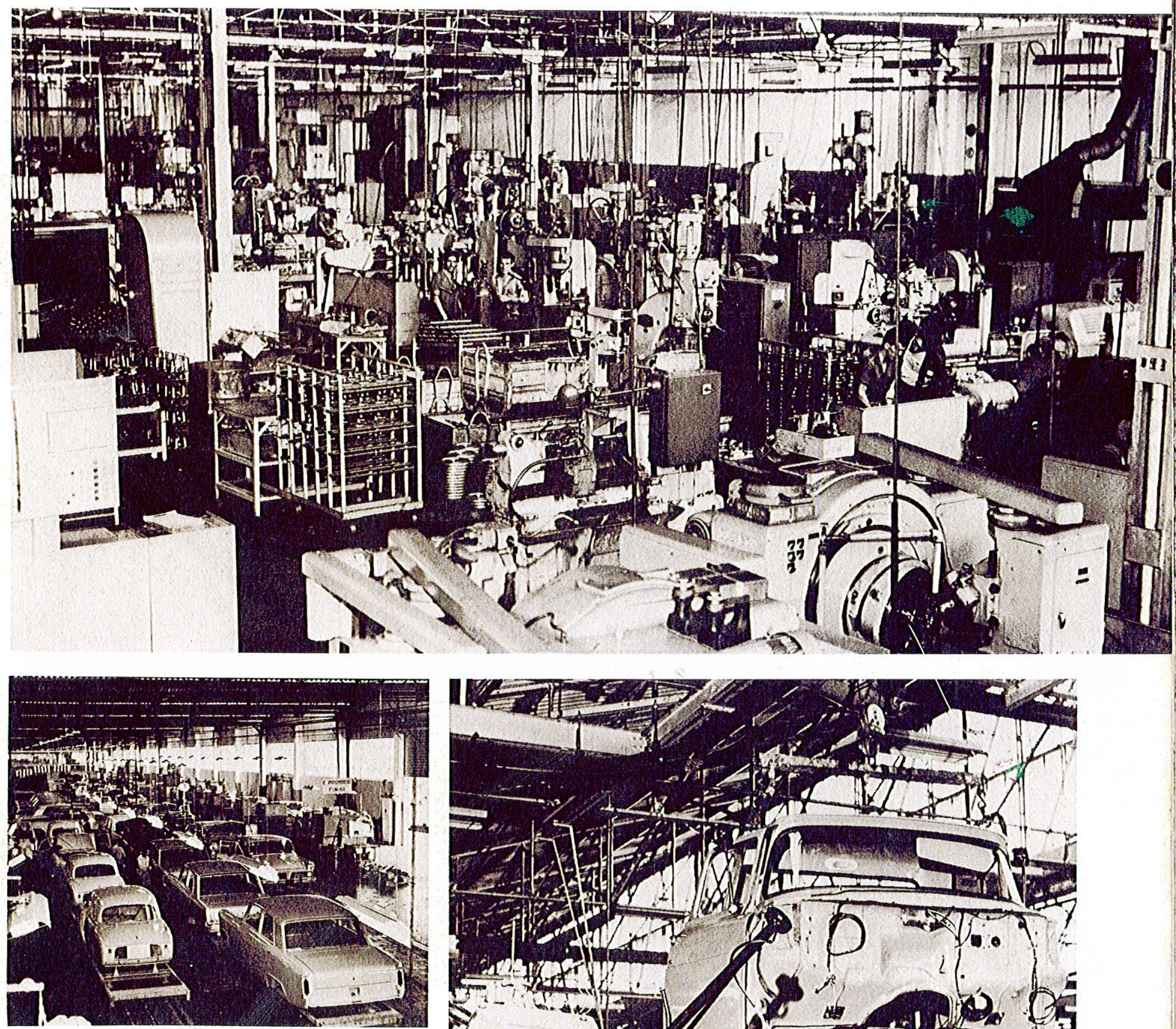

o operário brasileiro saiu-se galhardamente do desafio repre sentado pela complexa técnica da fabricação de automóveis, do. minando os seus segredos no veloz ritmo que the foi exigido.

Brazilian auto workers have sucessfully met the challenge posed by the complex technique of automobile manufacturing and mastered vely well its secrets with commendable alacrity.

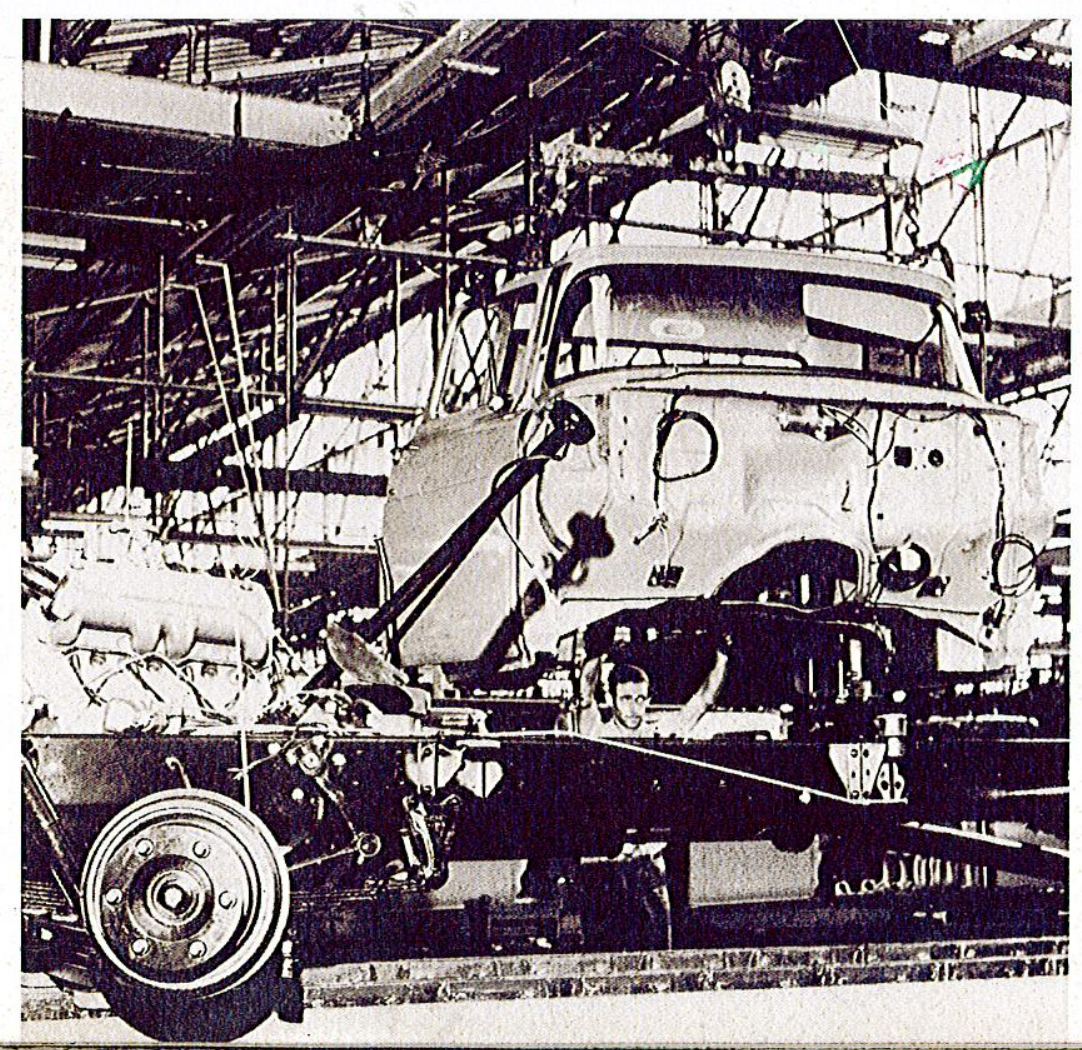




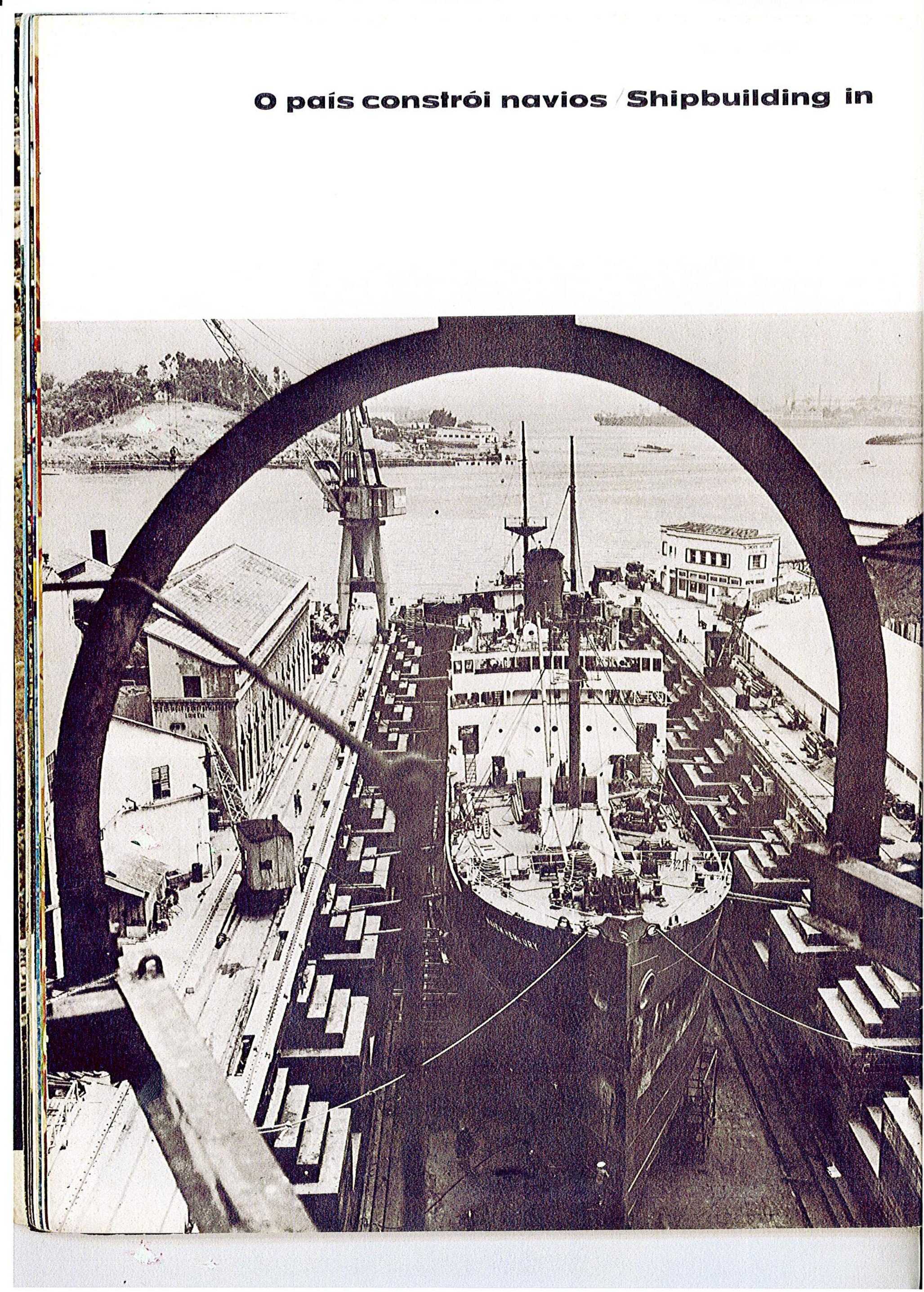




\section{Brazil}
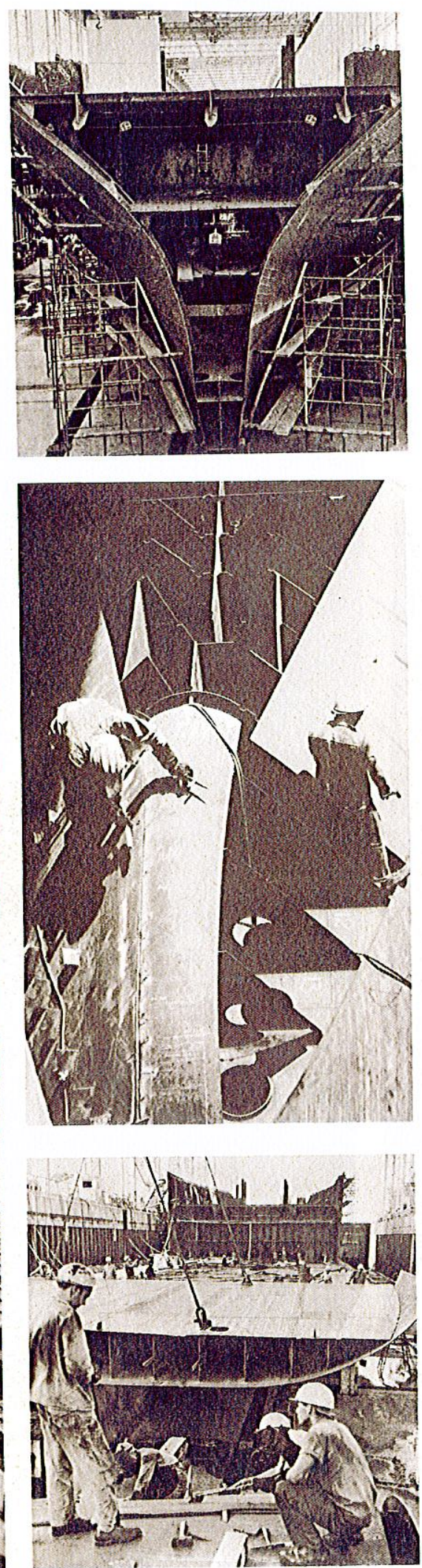

Os vários estaleiros brasileiros têm uma capa. cidade de produção de mais de 250.000 toneladas anuais. Podem construir navios de grande to-

Pruduction capacity of the shipyards installed in Brazil is $250,000 \mathrm{~d} . \mathrm{w}$. tons per annum. They are equipped to turn out high-tonnage ships, tankers, ferry boats, tugs and many others. mar trouxe 'as caravelas portuguêsas, em 1500, e hoje leva os grandes cargueiros construídos no Brasil, carregados de café e cacau, frutas e cereais, tecidos e produtos manufaturados. $\mathrm{O}$ Brasil possui hoje a maior indústria de construção naval da América Latina e já exporta navios para vários países, além de fornecer cargueiros e petroleiros para a frota mercante e da Petrobrás.

IN 1500 the sea brought the Portuguese discoverers' caravels. Today it takes Brazilian-built freighters with export cargoes of coffee and cacao fruits and grains, textiles and other manufactured articles. Brazil's shipbuilding industry is today the largest in Latin America. Not only is it exporting ships but it is supplying freighters for the Brazilian merchant marine and tankers for the Government oil company, constantly growing Petrobras.

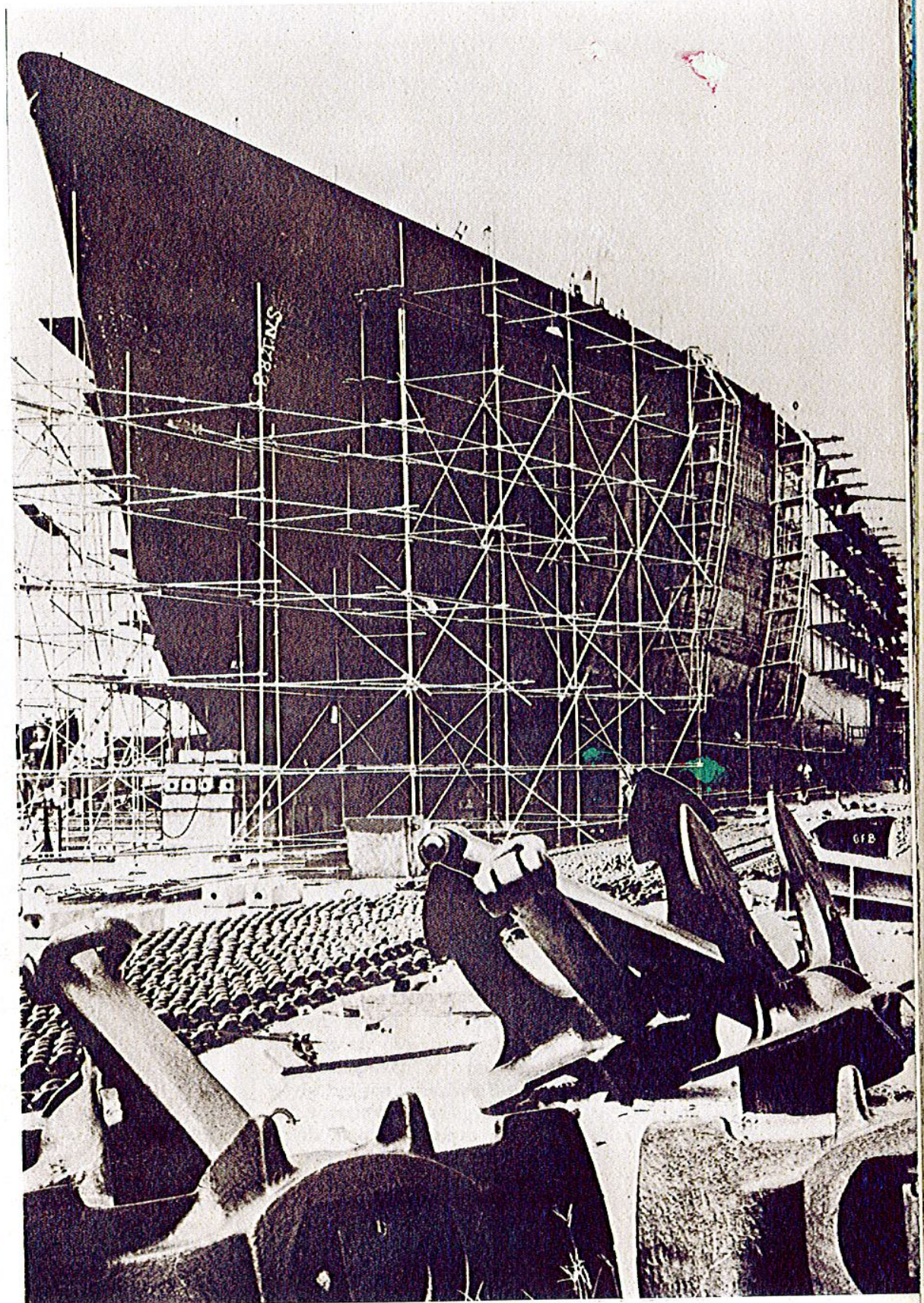




\section{Minérios Ores}

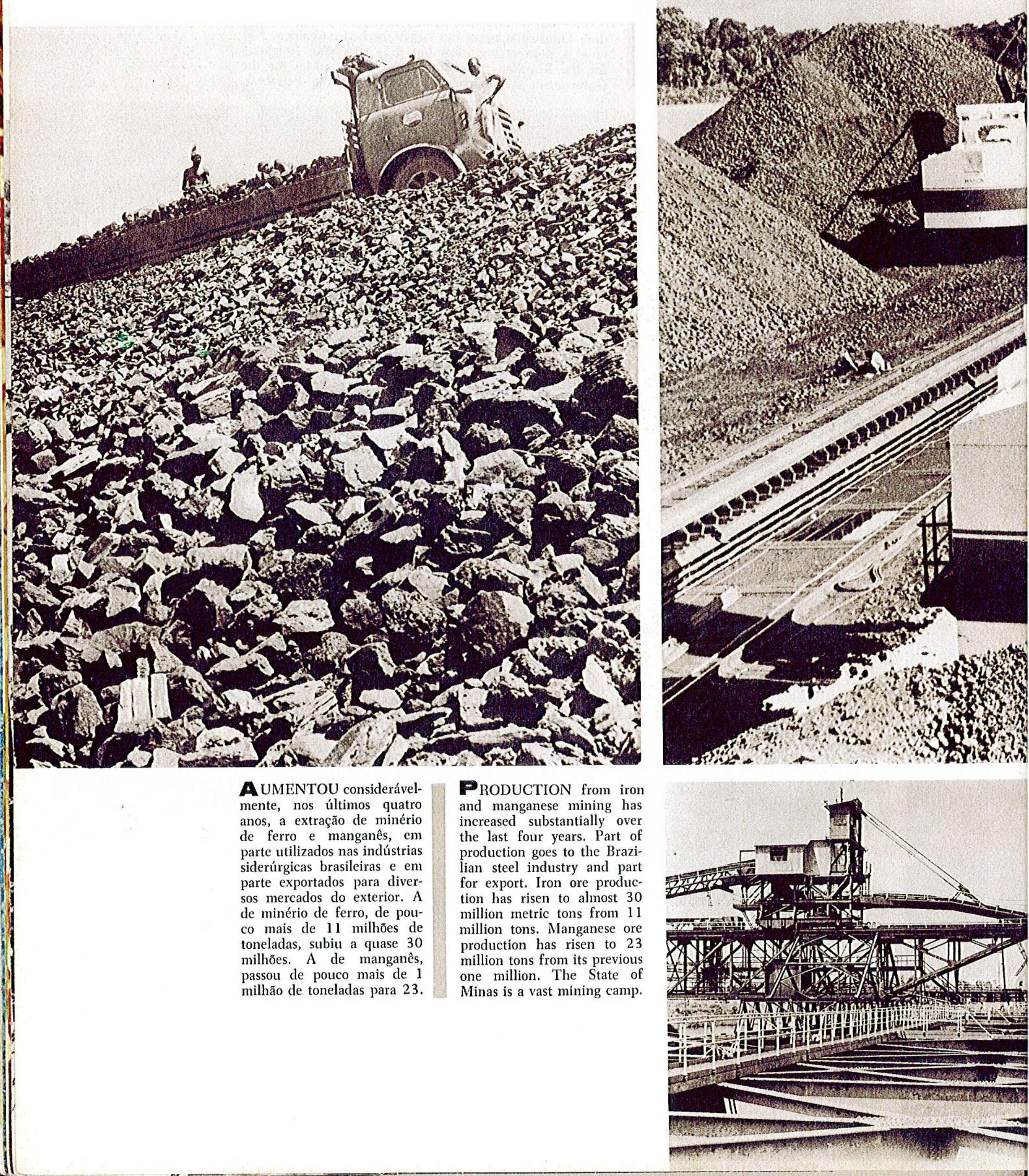




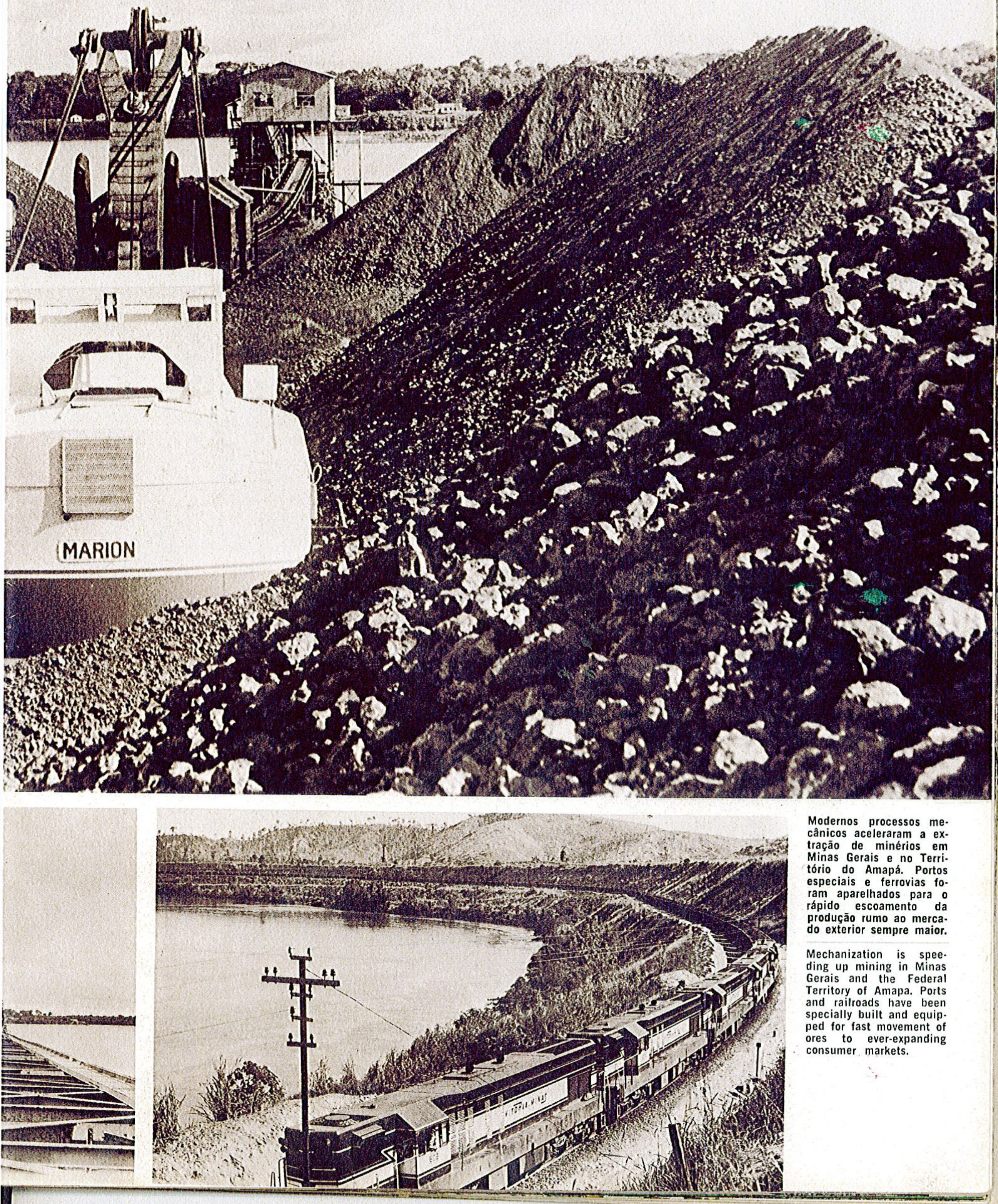




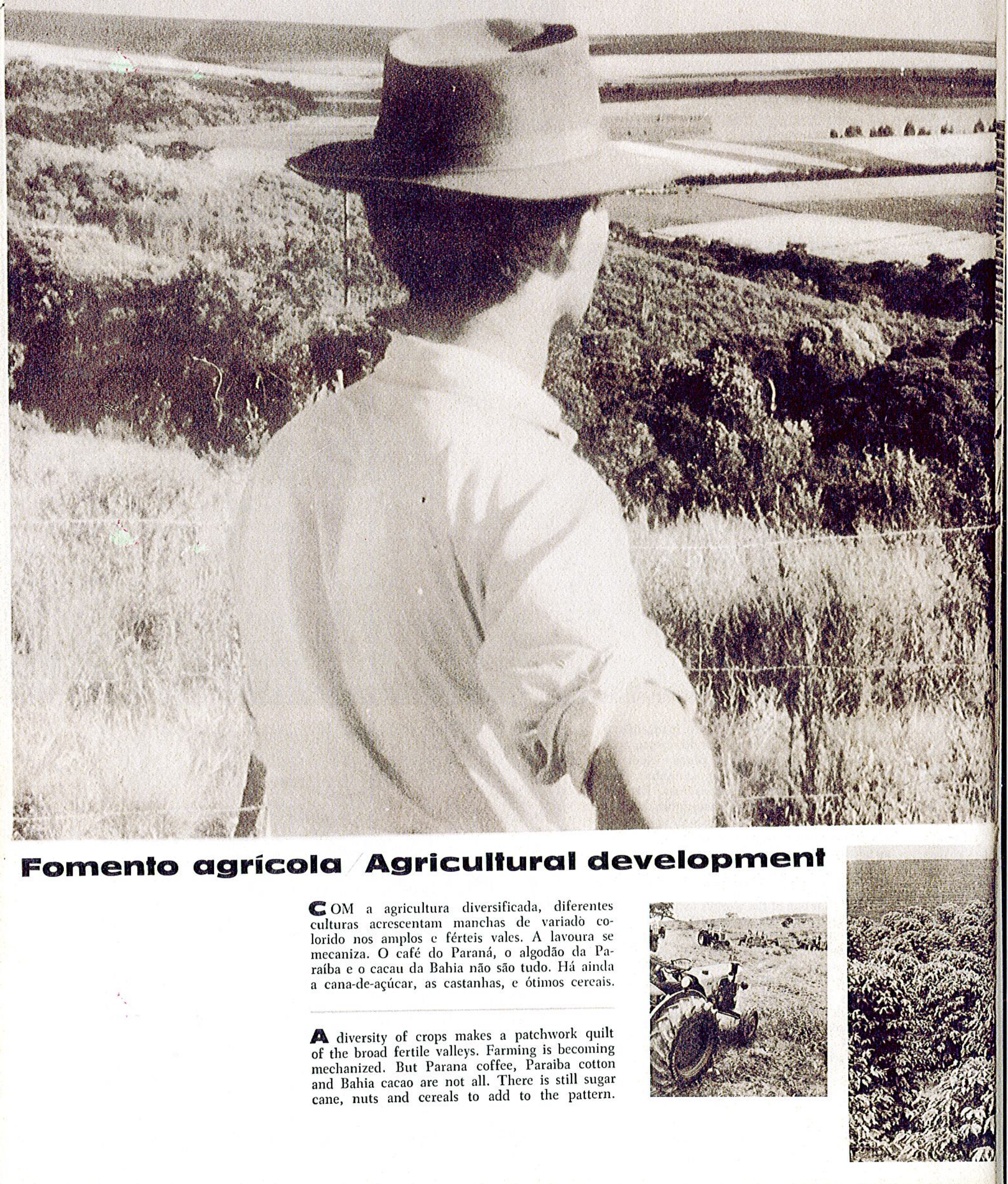




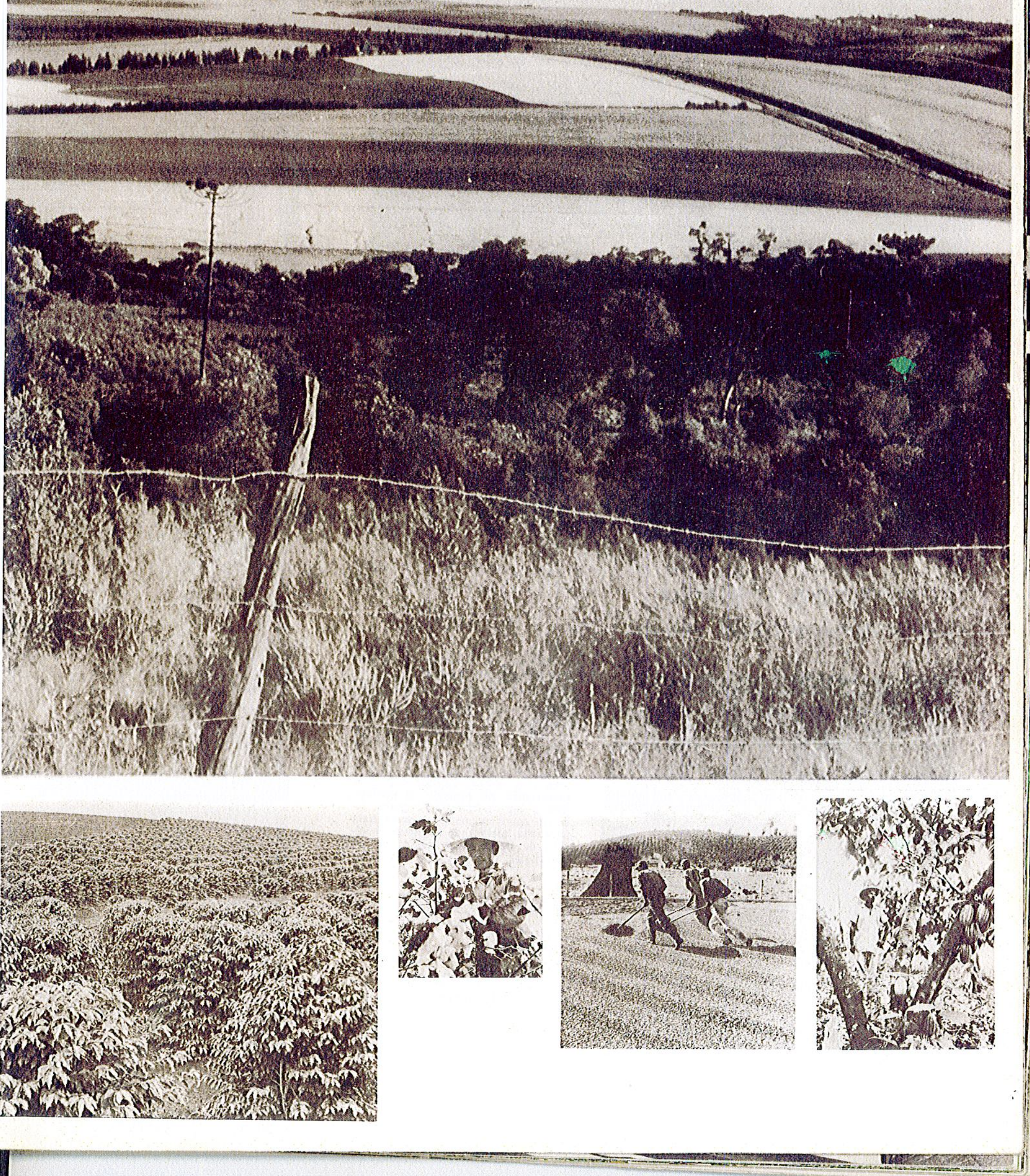




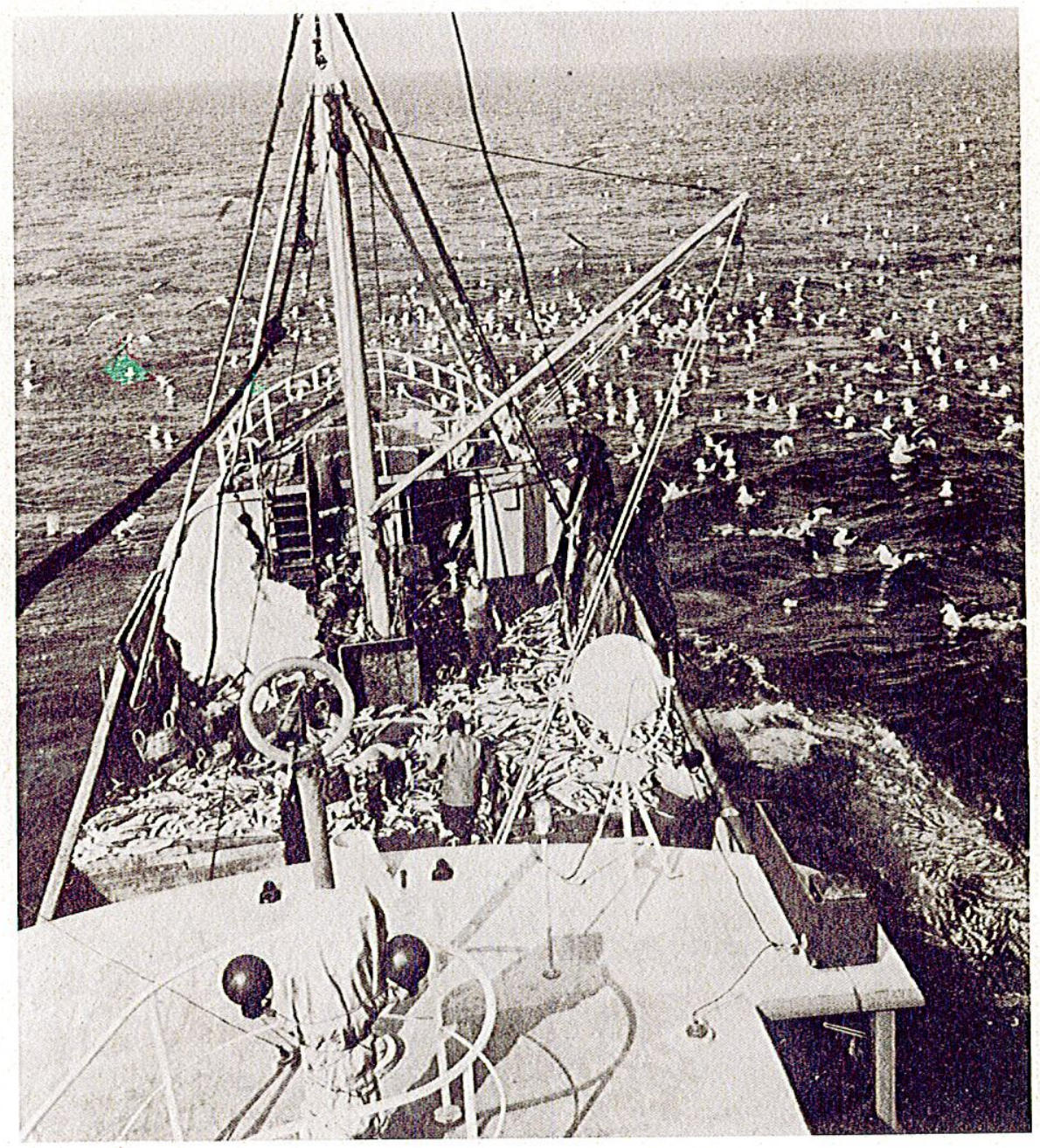

A grande pesca

\section{The bounifill sea}

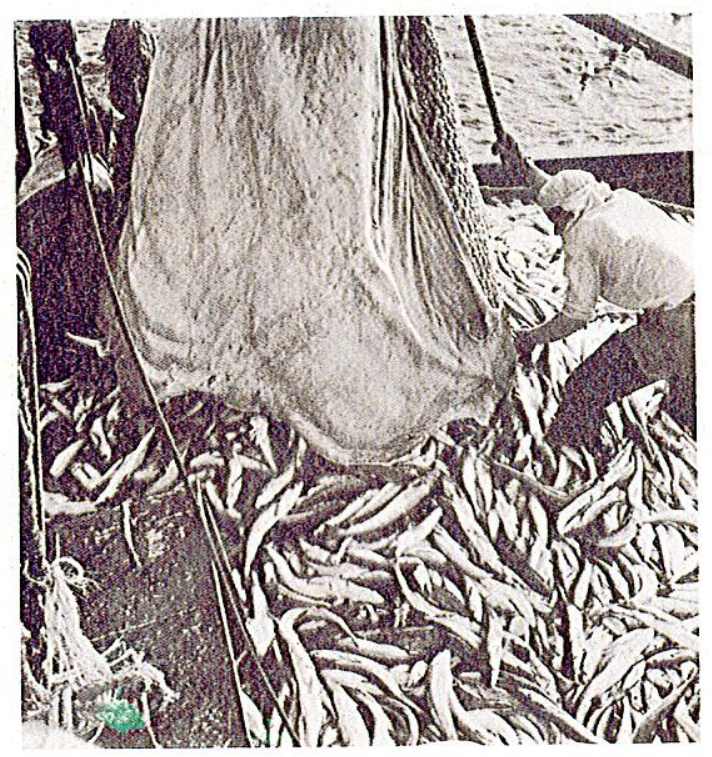

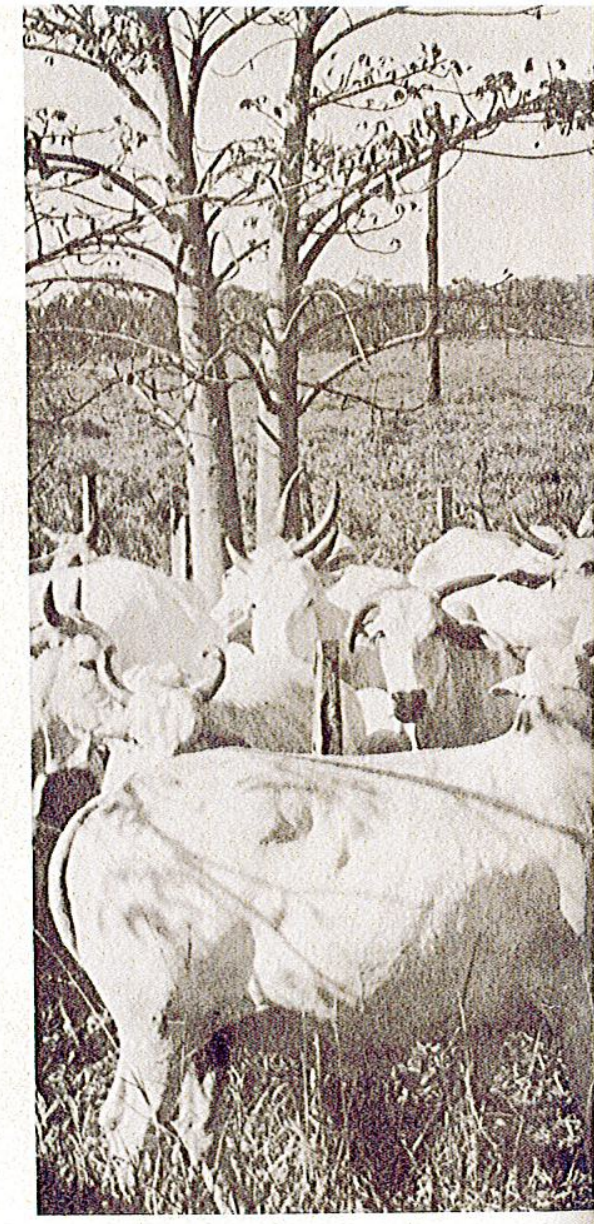

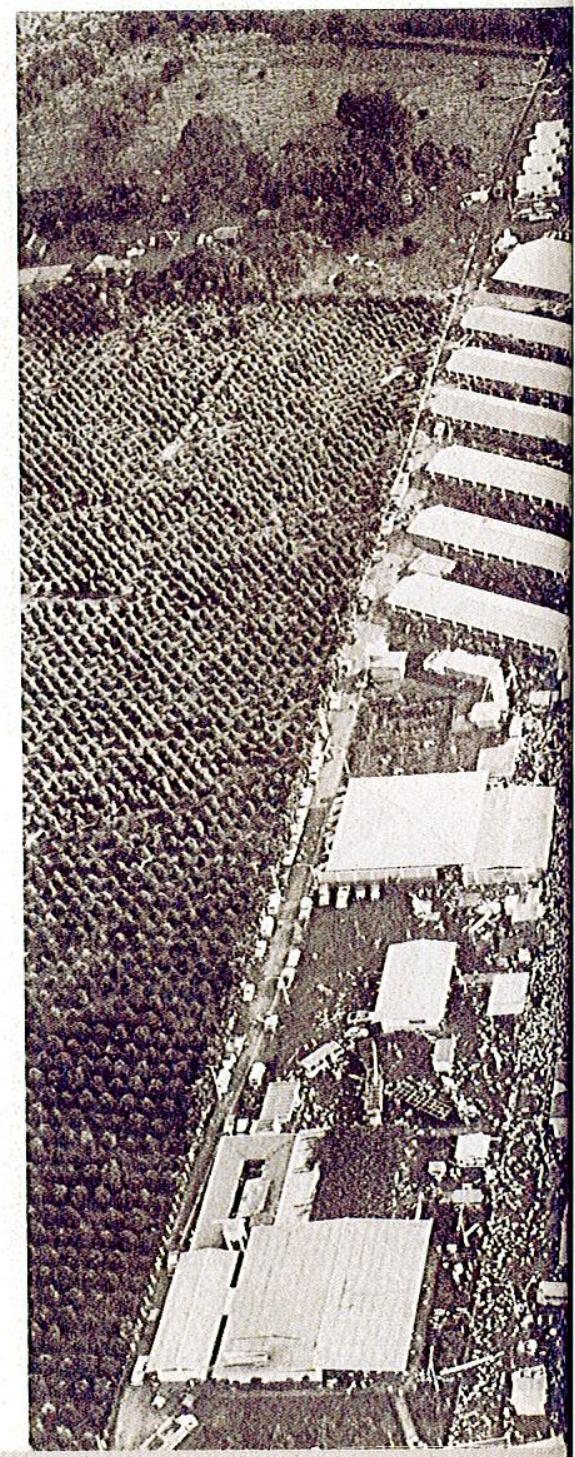




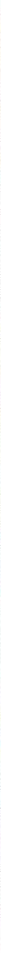

\section{Transportes em terra, ar e mar/Land, sea}

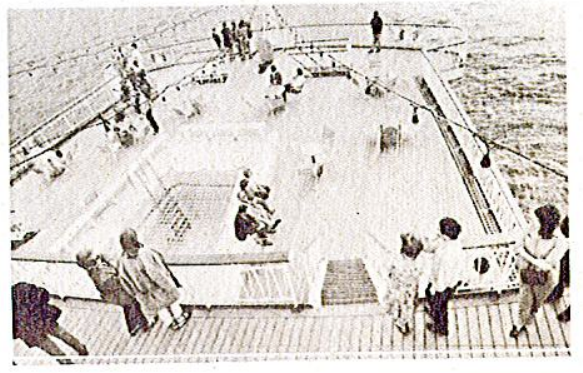

COM uma rêde de estradas de ferro nacionais $\mathrm{cm}$ expansão, ao lado das rodovias, o Brasil procura vencer suas distâncias internas. Uma grande frota mercante, fundada com a República, em 1889 , interliga os portos nacionais e leva passageiros e produtos aos mercados do mundo. Uma das maiores companhias internacionais de aviação comercial é brasileira: a VARIG, de natureza privada. Além desta, muitas outras operam ativamente nas linhas domésticas.

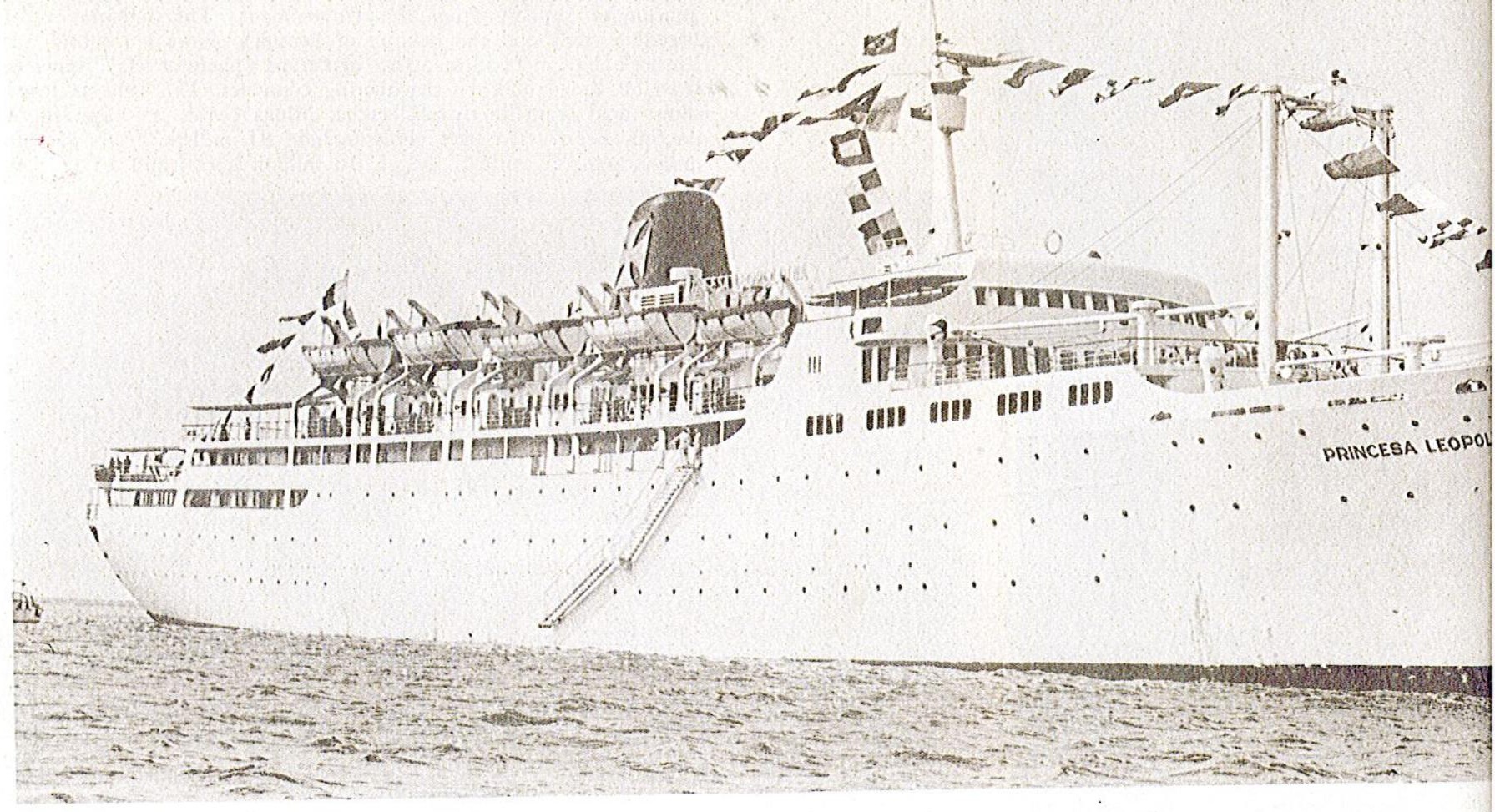




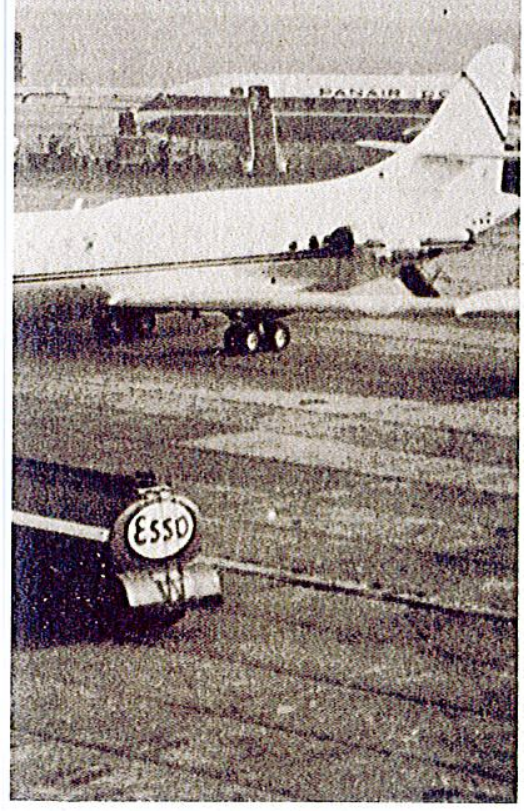

and hransporis

MIGHWAY and railroad networks are being expanded in Brazil to shorten the enormous distances. A merchant marine fleet, as old as the Republic, handles coastwise and transocean passenger and freight traffic. VARIG airlines, a privately owned company, is one of the largest in the world. There are also other domestic air transport companies operating in Brazil, linking the country from the Amazon forest to the southernmost Brazilian State Rio Grande do Sul.

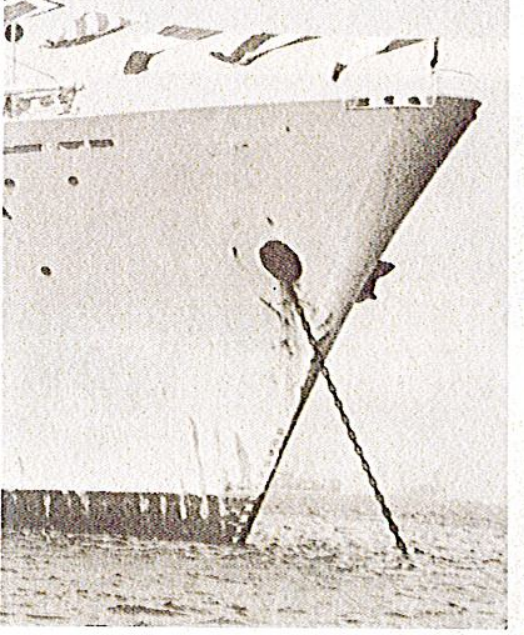

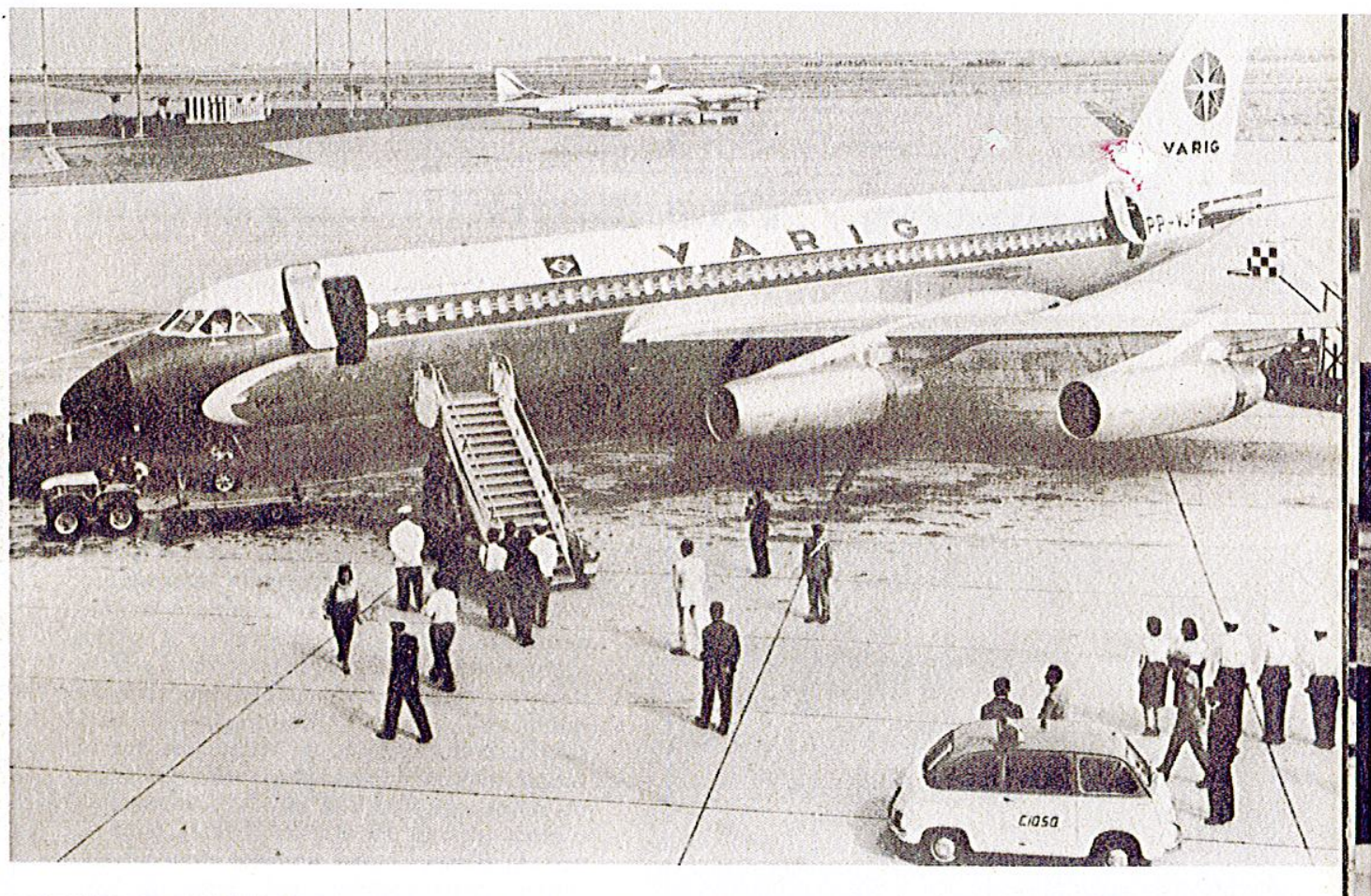

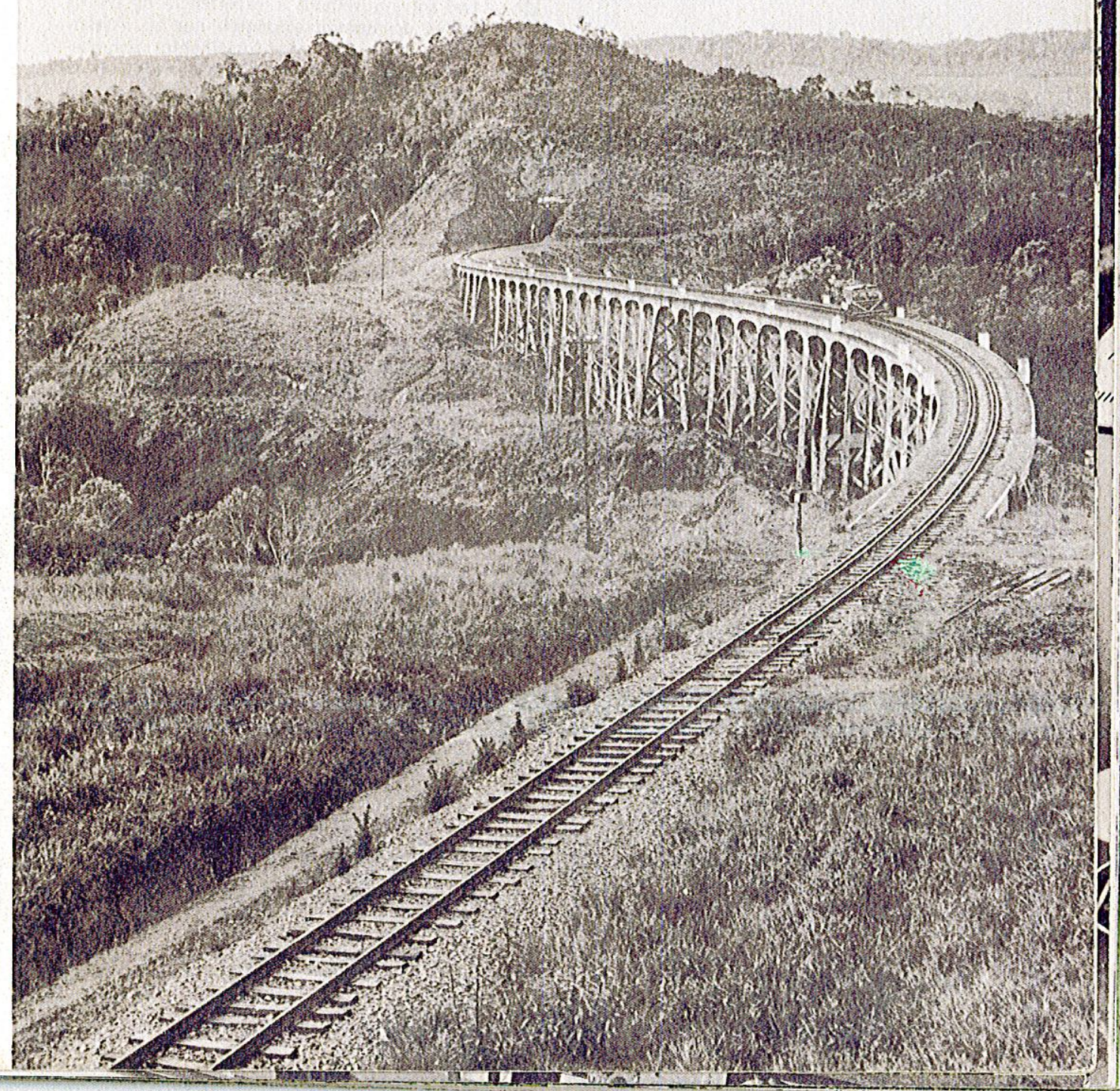




\section{Finanças / The Banking System}

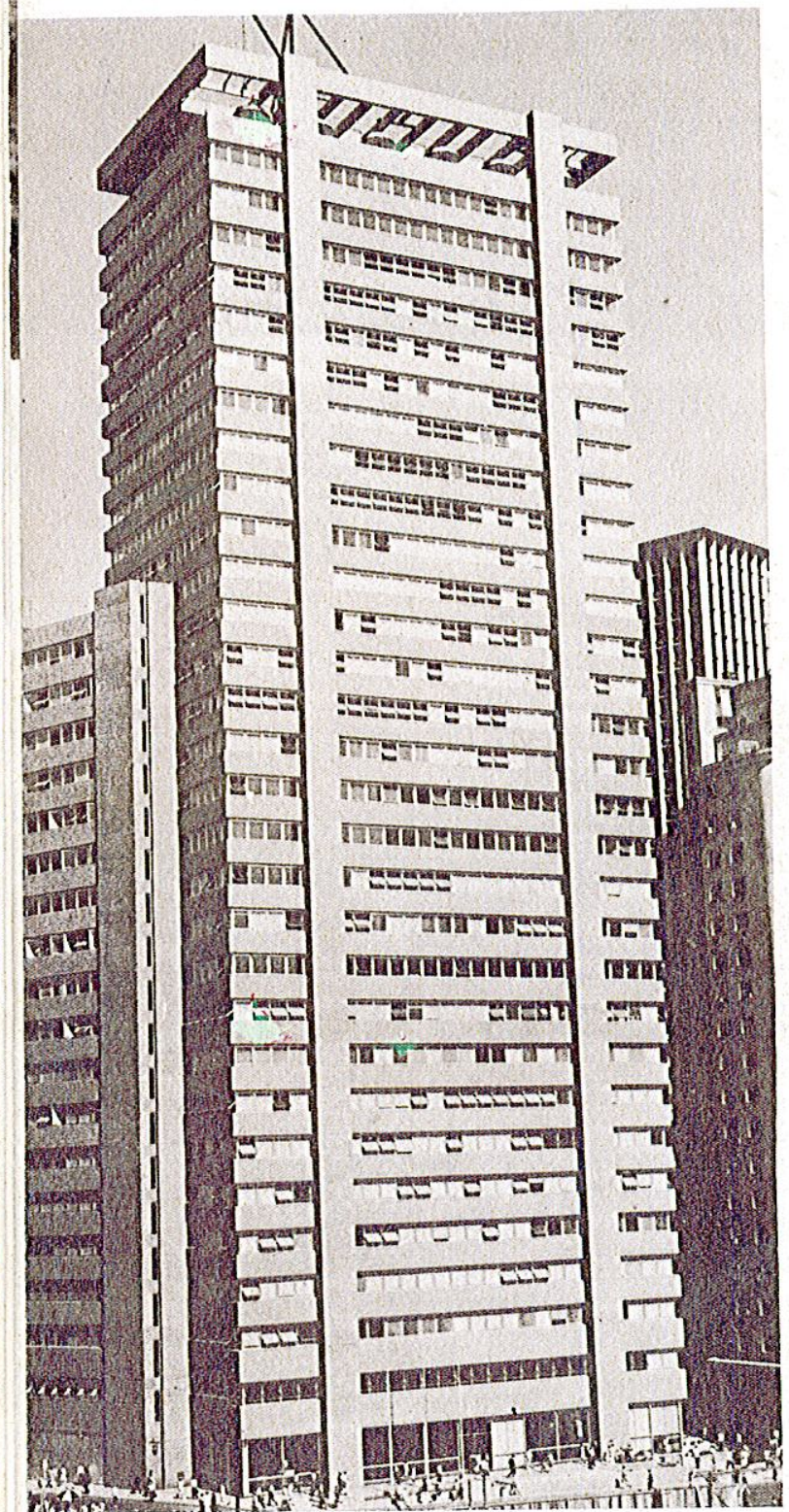

o Banco do Estado da Gua nabara, no Rio de Janeiro, possui esta moderna sede é um dos bancos que mais cresceram nos últimos anos.

The Guanabara State Bank located in Rio, owns this one of the banks which more developed in recent years.
A vida financeira do Brasil tem no Banco Central o seu mais importante instrumento regulador. Sua criação correspondeu a uma necessidade imperiosa, substituindo a antiga Superintendência da Moeda e do Crédito Não se tratou de uma simples mudança de rótulo, mas de uma reestruturação e de uma considerável ampliação de atribuições que se faziam imprescindiveis, para maior eficiência do nôvo órgão, na sua missão coordenadora e disciplinadora das atividades financeiras do país. O Banco Central também absorveu atividades antes exercidas pelo Banco do Brasil, por delegação do Ministério da Fazenda. $\mathrm{O}$ saneamento do meio bancário brasileiro começou a ser feito com o necessário rigor, ao mesmo tempo que, em estreita colaboração com o Conselho Monetário Nacional, o Banco Central procurava dar consistência ao mercado financeiro, através de amparo às companhias de investimento, de incentivos ao mercado de capitais e de crédito direto ao consumidor. Na criação do Banco Central foi aproveitada a experiência de outros países do mundo ocidental, que se defrontaram com problemas semelhantes aos nossos e que conseguiram solucioná-los com a fundação de idênticos Bancos Centrais. Assim, após tímidos ensaios e vacilações anteriores, o Brasil tem hoje um órgão coordenador das atividades financeiras básicas, adaptado às contingências de seu progresso.

THE Banco Central is the regulating force of Brazilian finances. It was created in 1965 to replace the old Administration of Money and Credit (SUMOC). It also took over functions formerly performed by the Banco do Brasil. Wceking in close cooperation with the National Monetary Council, the Banco Central aims to strengthen the economy by giving support to investment companies, incentives to the capital market and credit directly to the ponsumer. It is a Bank on the lines of those in other countries of the Western world.

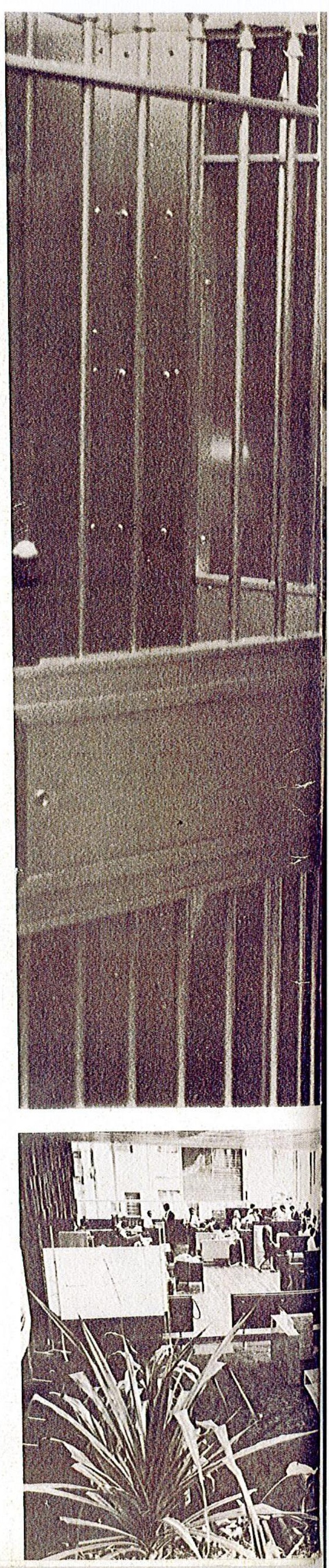




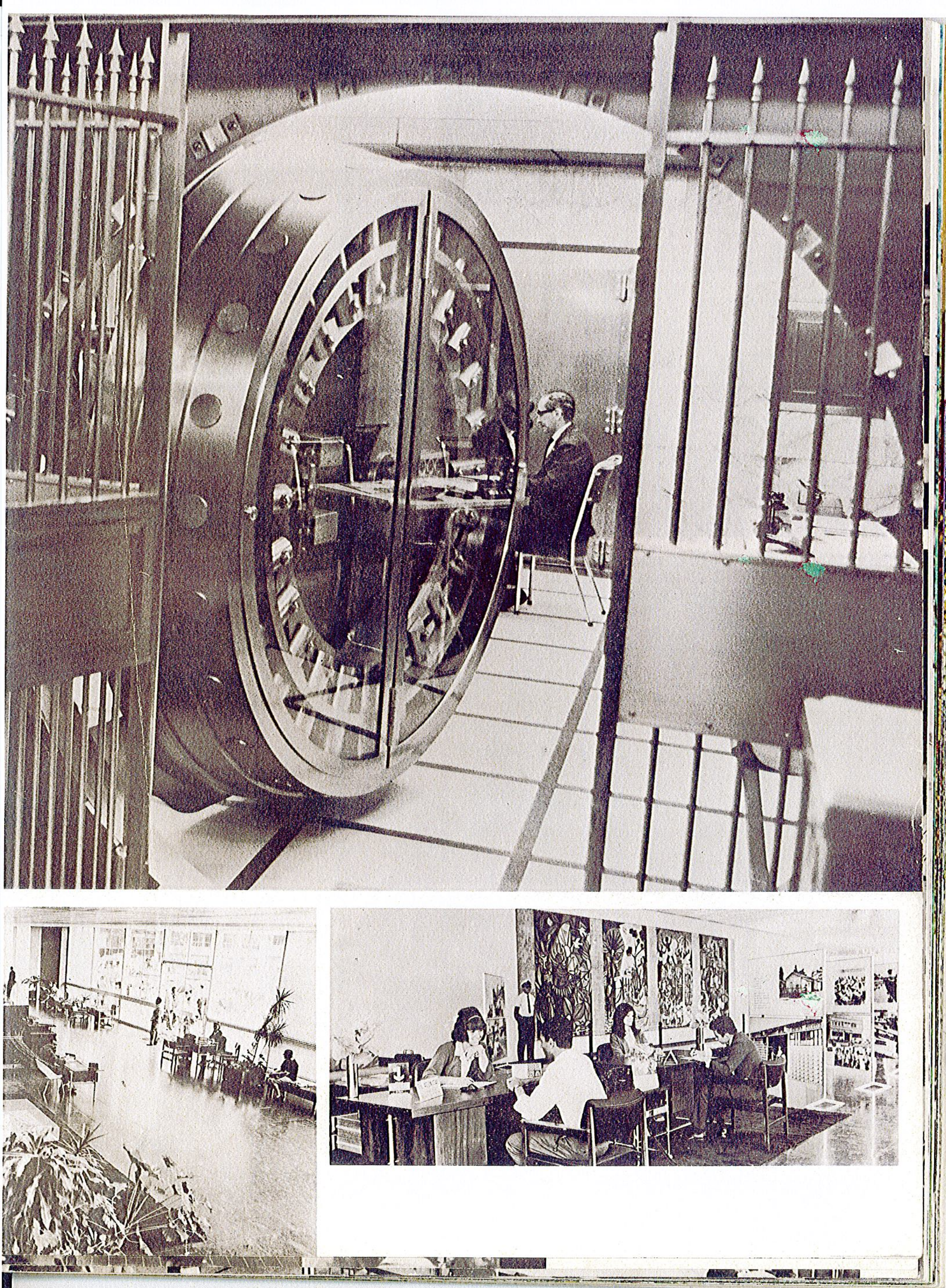



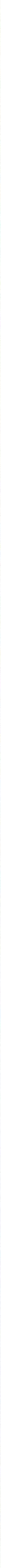

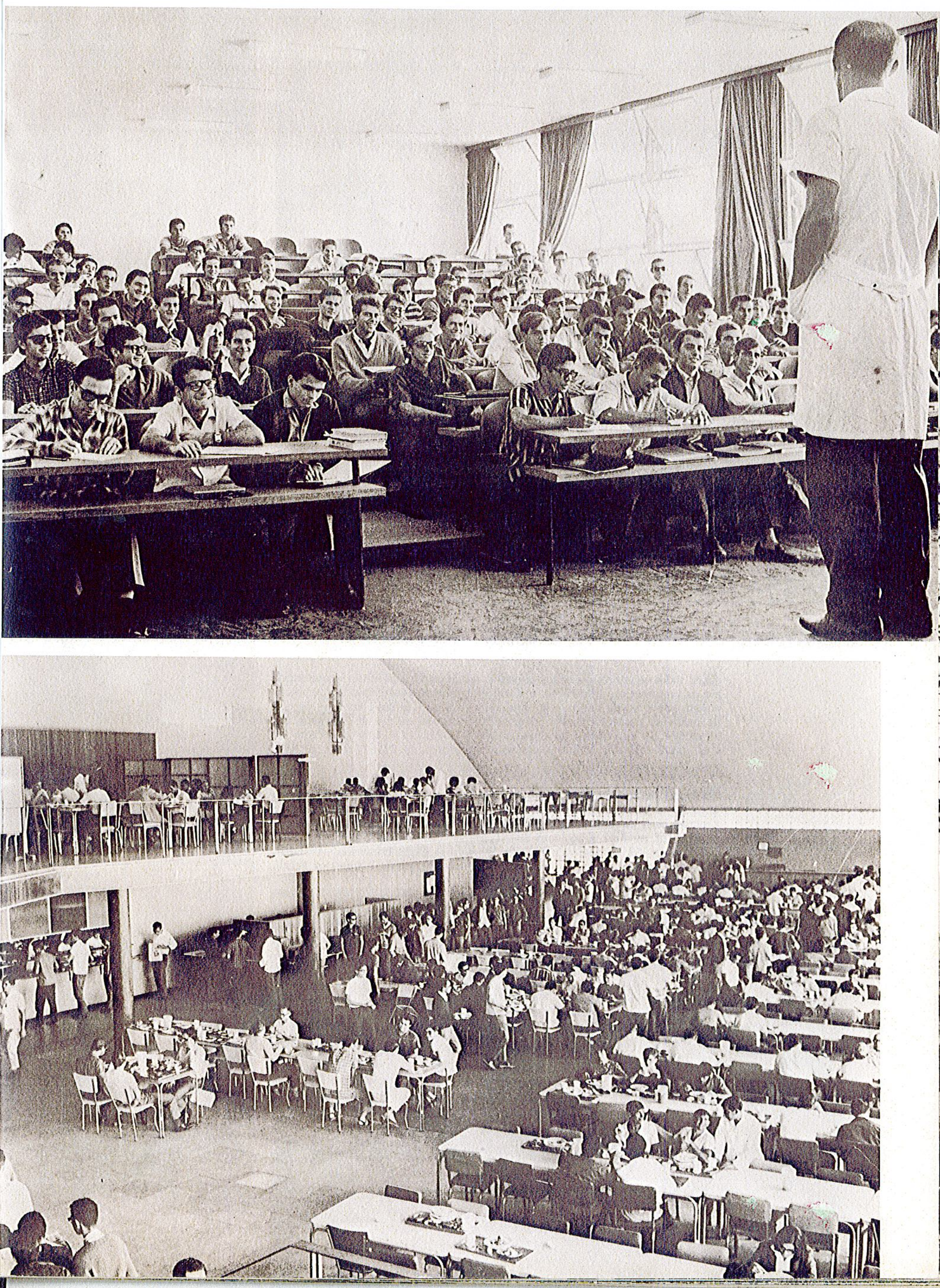


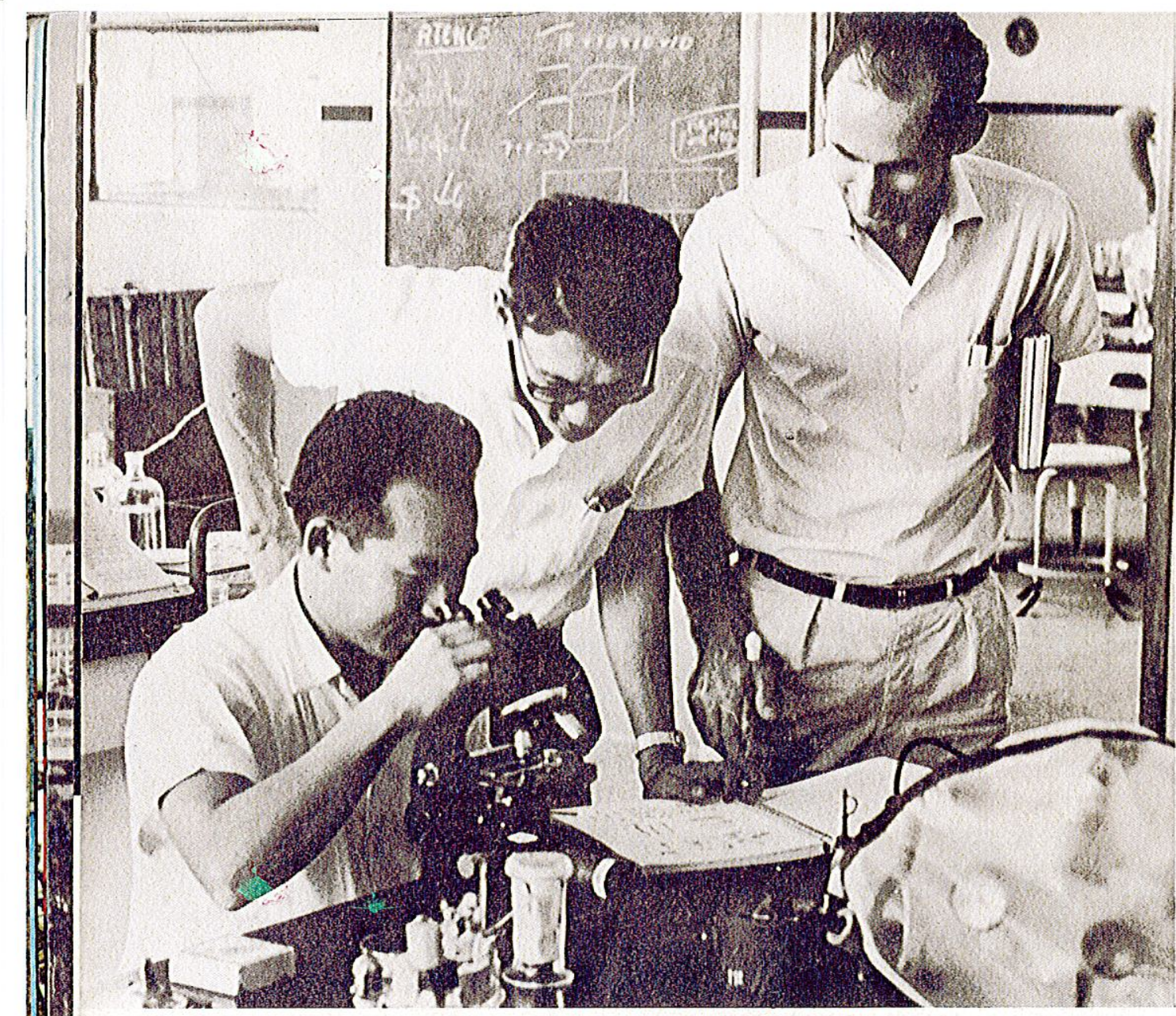

\section{Ensino New feaching techniques}

EM todos os setores do ensino superior, desde os da agricultura e veterinária aos da arquitetura e urbanismo, o Brasil está fazendo progressos. Em nenhum, porém, como no da engenharia. Enquanto, nos três últimos anos, as escolas de medicina aumentaram de 36 para 38 e as de direito de 60 para 62, as escolas de engenharia aumentaram de 97 para 124, com o número de seus alunos subindo, de forma altamente animadora, de 15.617 para 21.986.

ERAZIL is making progress in every field of teaching, from agriculture to animal husbandry, city planning to architecture. But nowhere has the progress been as great as in engineering. While over the past three years the number of medical schools increased to 38 (from 36) and law schools increased to 62 (from 60), 27 new schools of engineering were founded, bringing the total to 124. Sao Paulo is the leading technical center of Brazil.
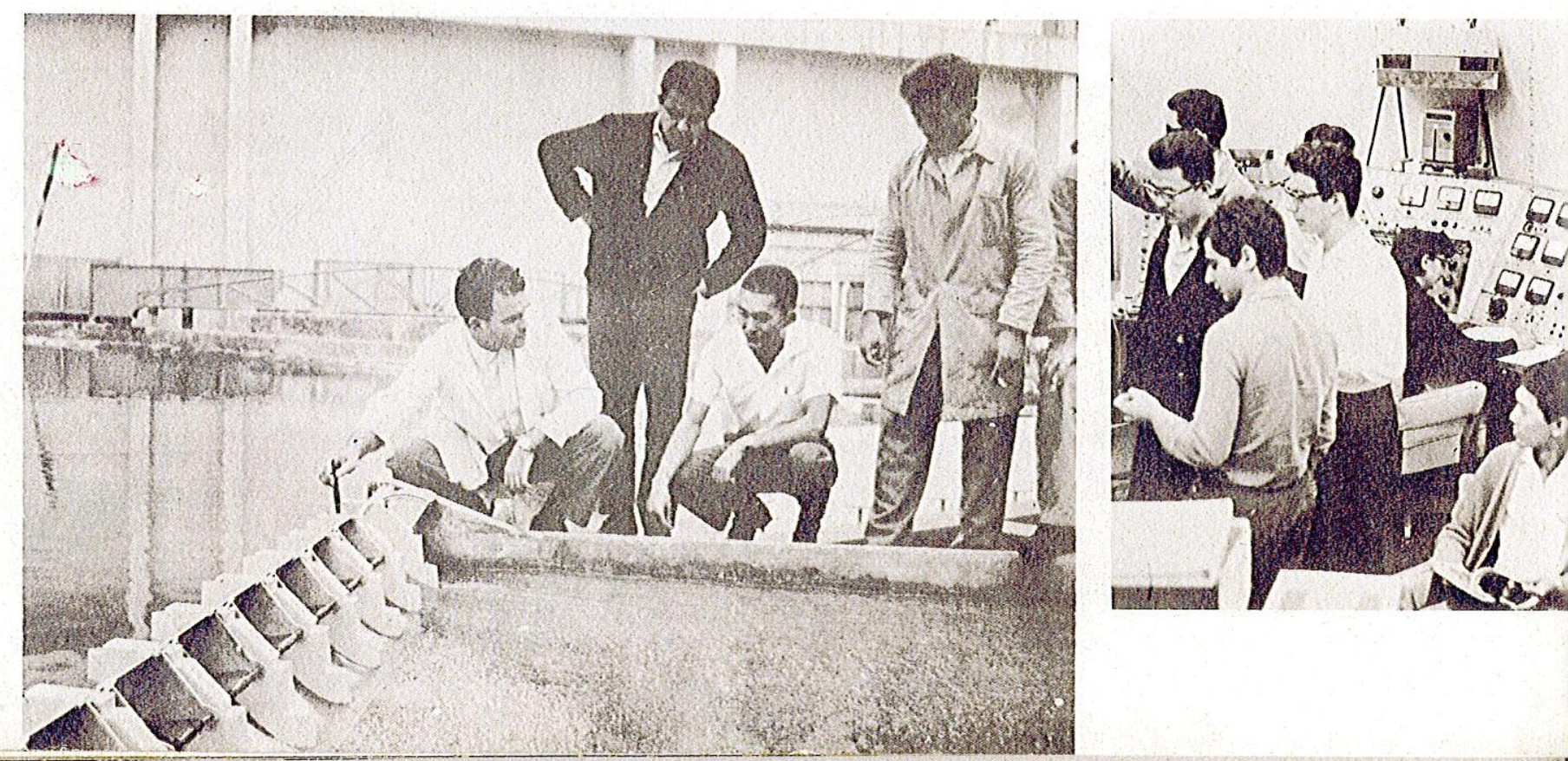


\section{Reahores atônicos para a paz Aloms for peace}

COM as novas tendências que orientam a vida universitária brasileira, as inteligências jovens se voltam cada vez mais para o estudo de matérias como a eletrônica, a química, a física nuclear, que abrem novas e amplas perspectivas. O Brasil já formou uma mentalidade atômica e quer fazer progressos no domínio nuclear, utilizando melhor seus laboratórios e institutos de pesquisas. As principais universidades do país já têm reatores atômicos próprios. Ao mesmo tempo, o país se prepara para entrar na era espacial.

INTERESTS of the new youth are turning increasingly to electronics, chemistry and nuclear physics because of the job advantages these subjects offer. Brazil's principal universities have their own atomic reactors for research and Brazil is preparing to enter the space era. Besides atomic reactors, the country has very large deposits of atomic minerals.

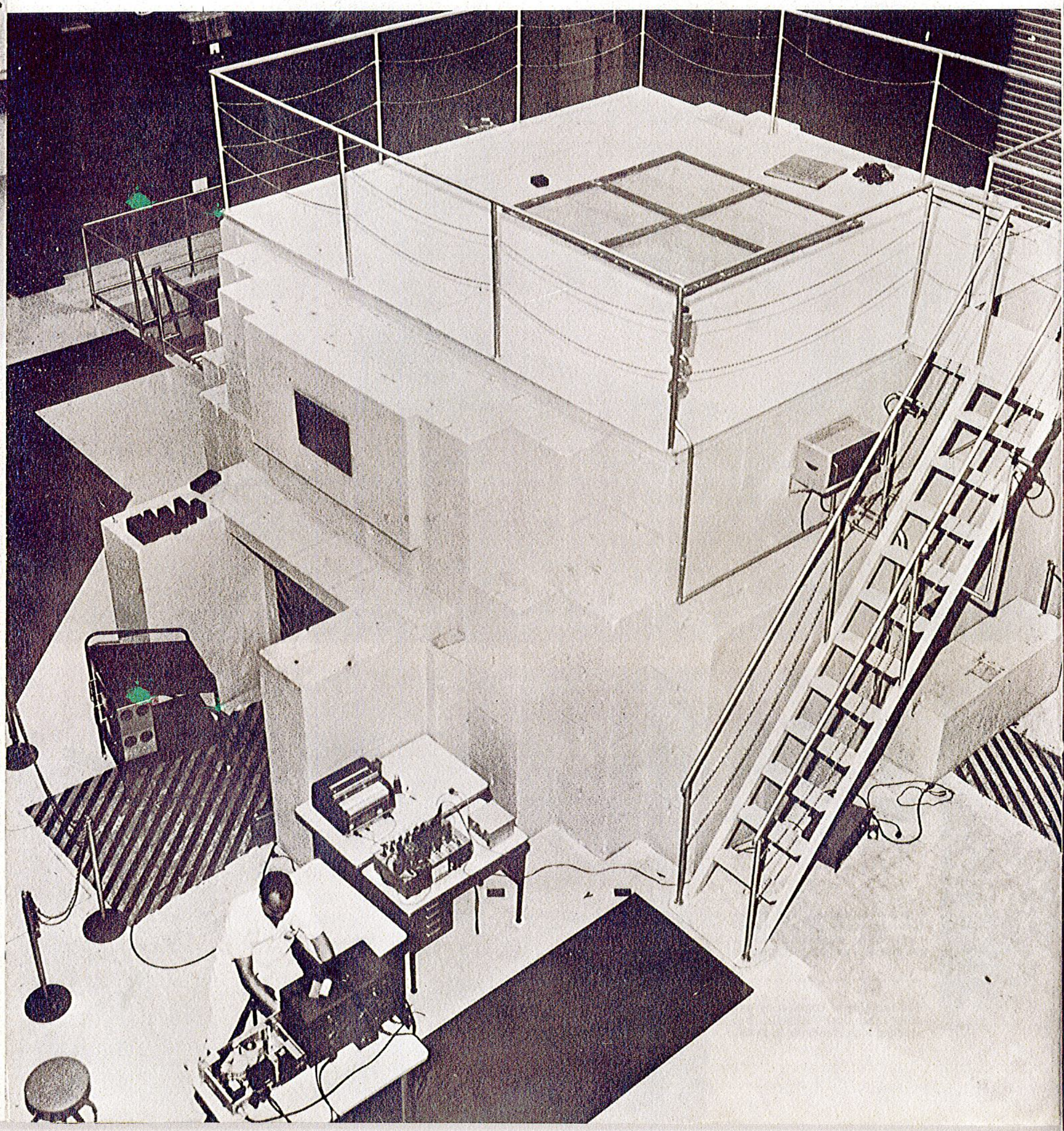



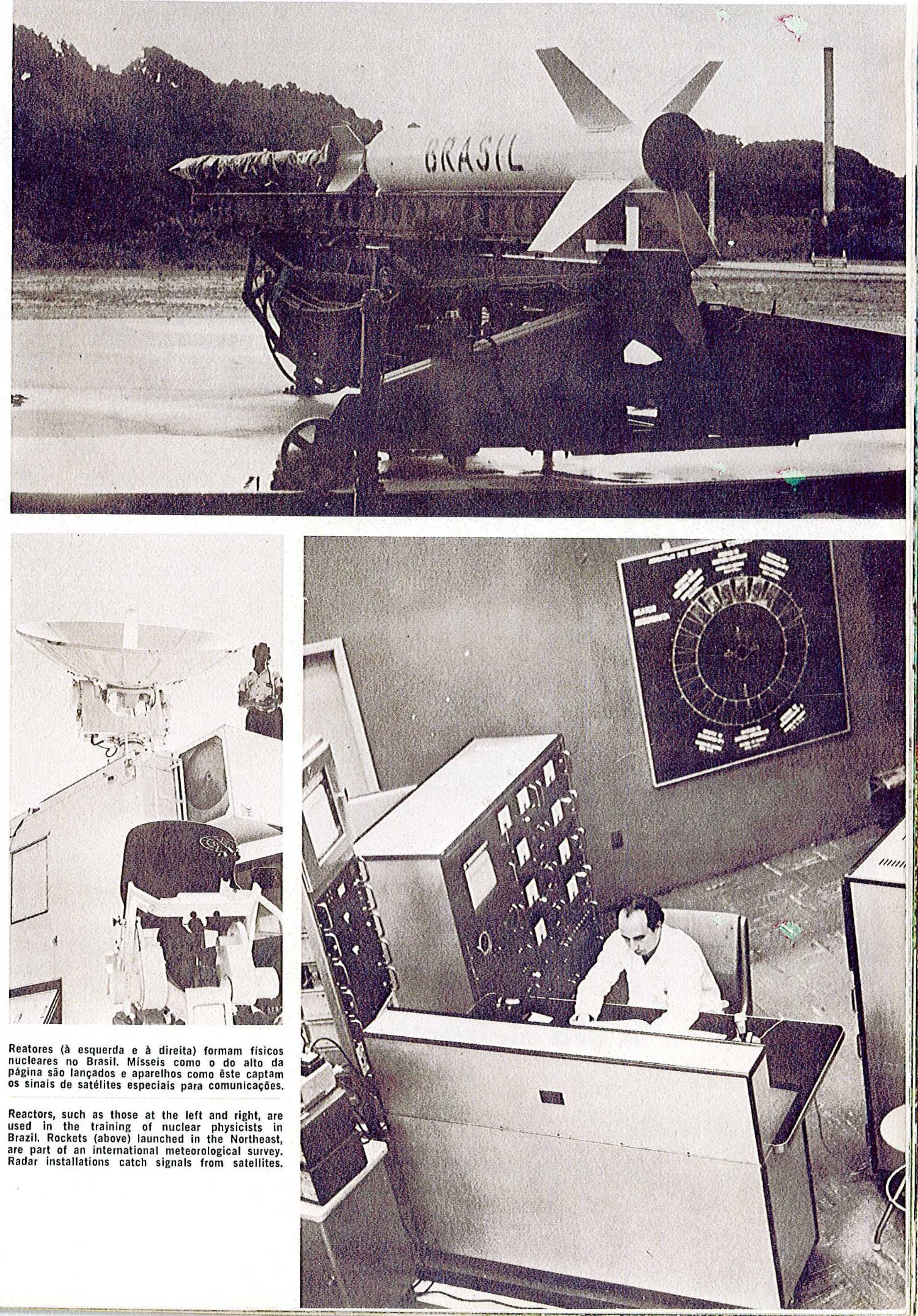


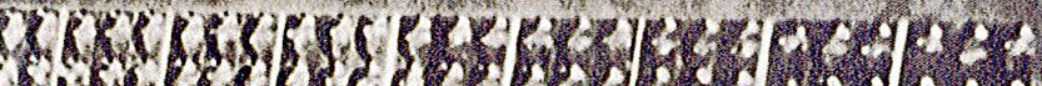

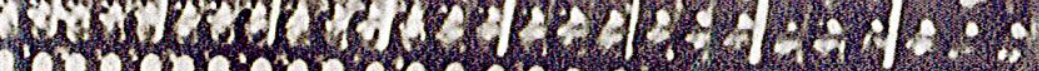

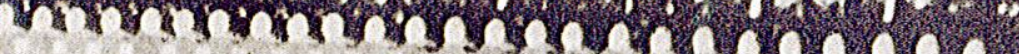

, (3) mom (tom

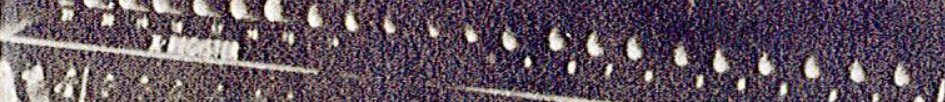
Vil $\cos (\cos )$

$$
y^{4}
$$

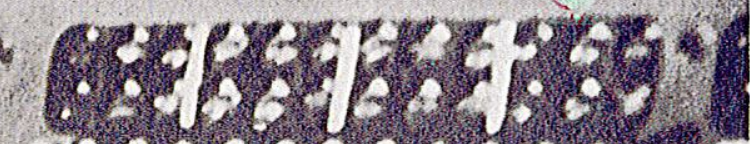

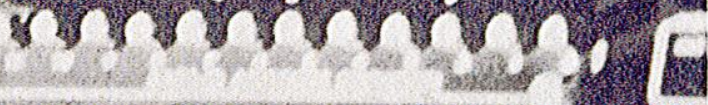

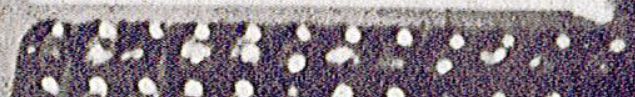

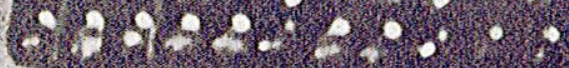

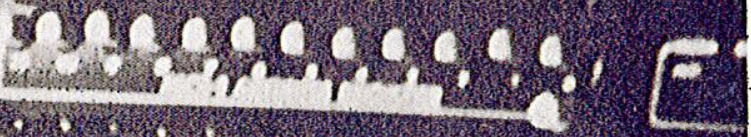

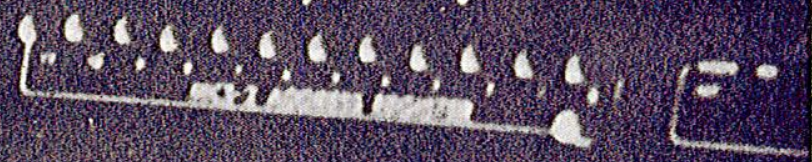

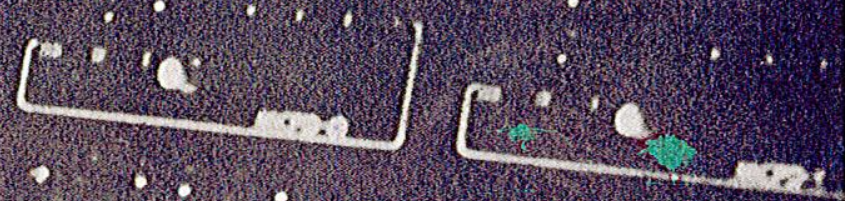

$i x$

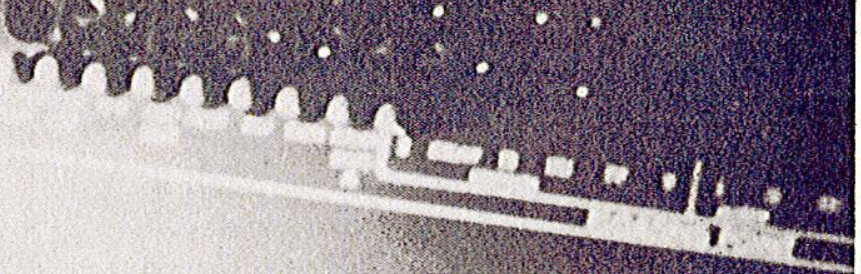
688 $-$
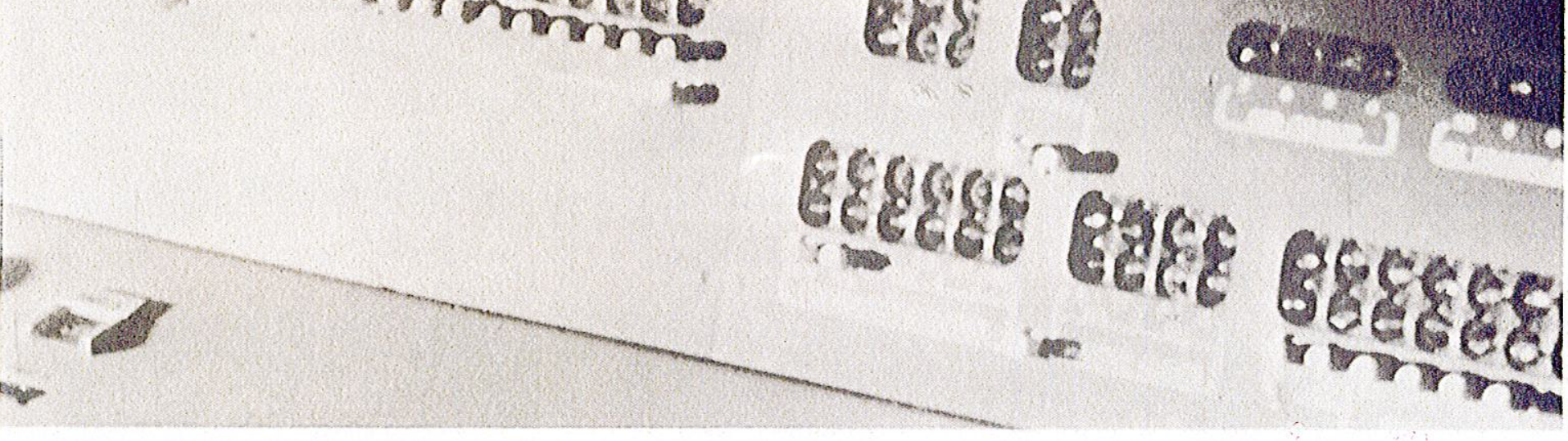

8Eges

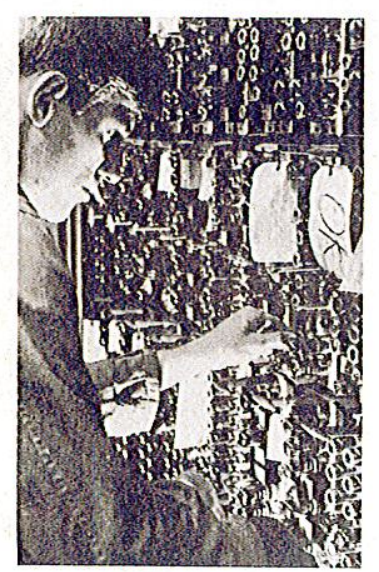

Além de uma indústria eletrônica que fabrica grande variedade de produtos e atende a todo o consumo interno, o Brasil possui a única estação de telecomunica ções da América Latina. Hoje, o pais comunica-se ràpidamente com tôdas as partes do mundo.

Apart from a modern electronics industry, equipped to supply do. mestic demand, Brazil has the only telecommunications station in Latin America. Brazil today is in instant contact with all parts of the five continents. 


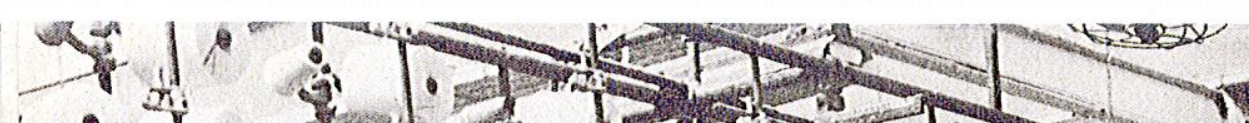

- i.

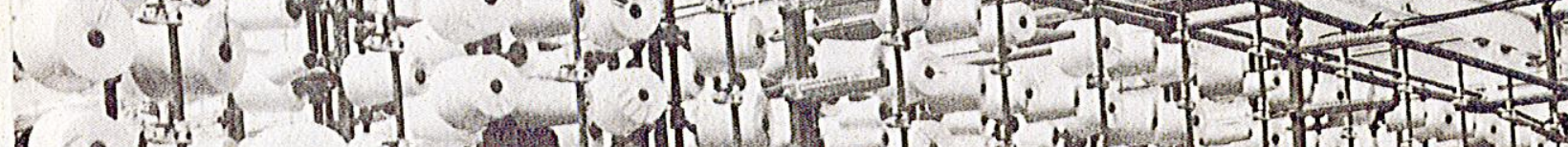
cor

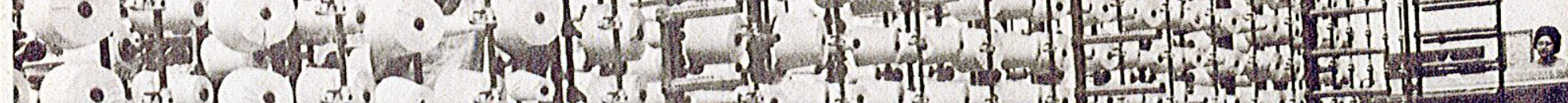

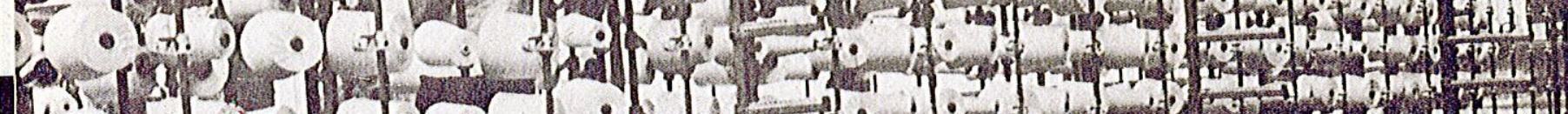

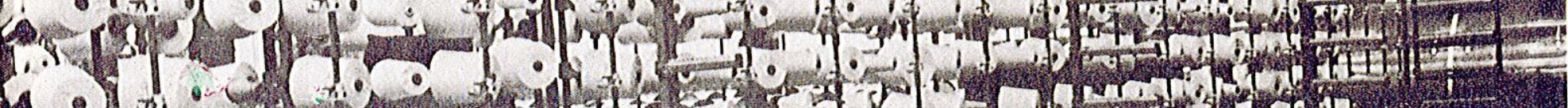

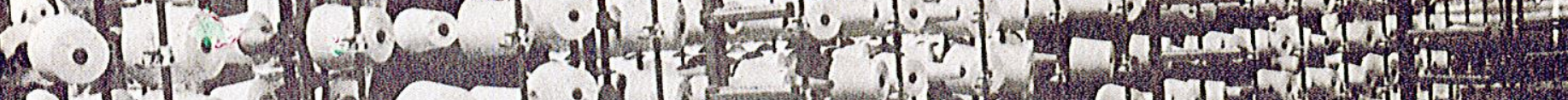

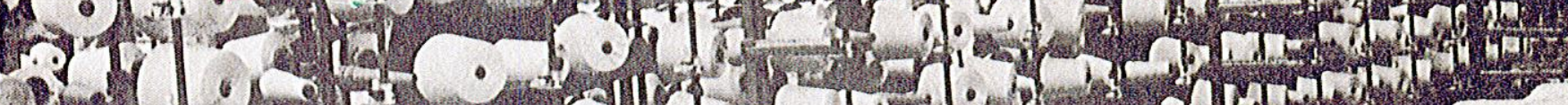

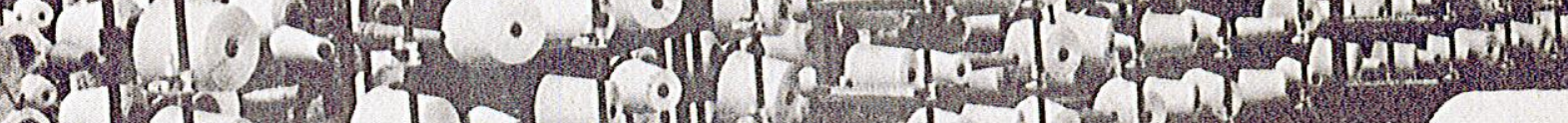

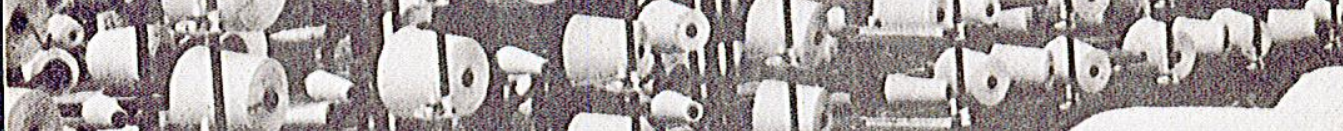
$s^{3}-1,50$

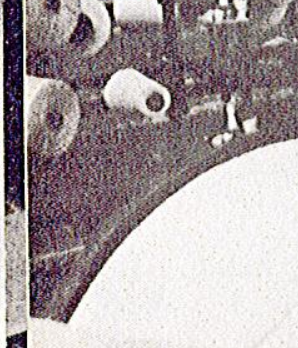




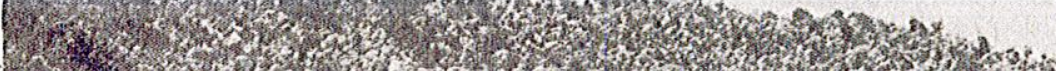

2.1.

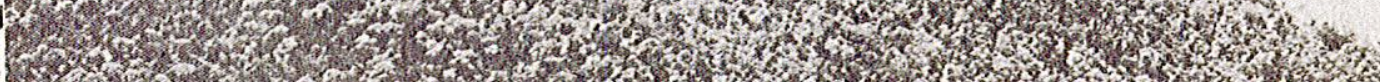

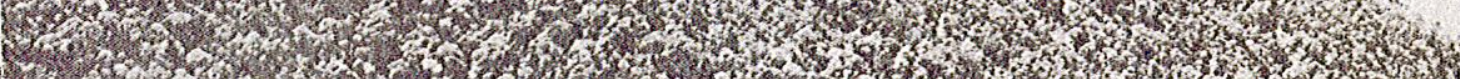

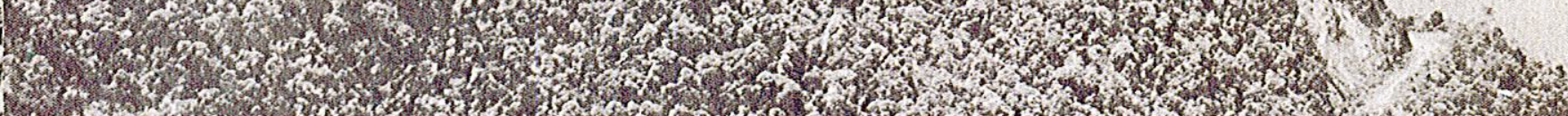

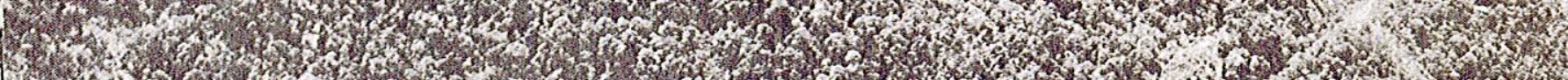

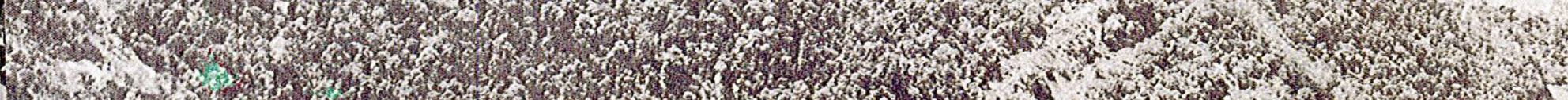

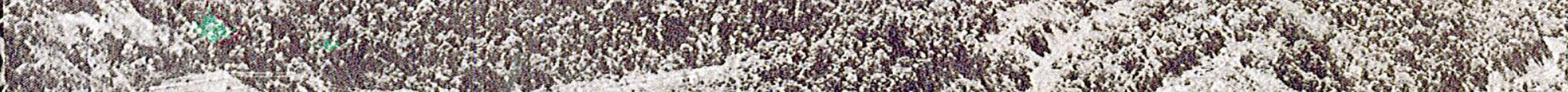
1.7.

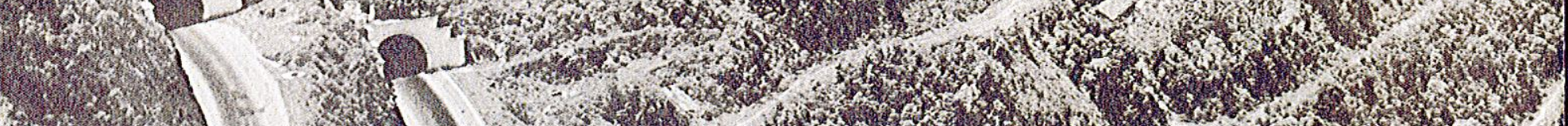
1517.

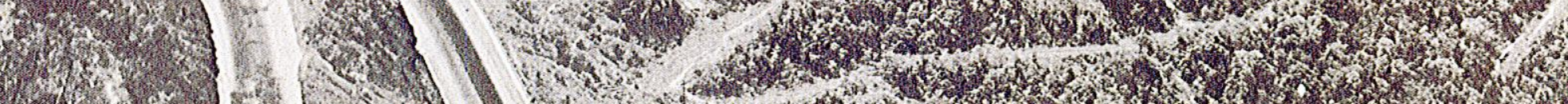

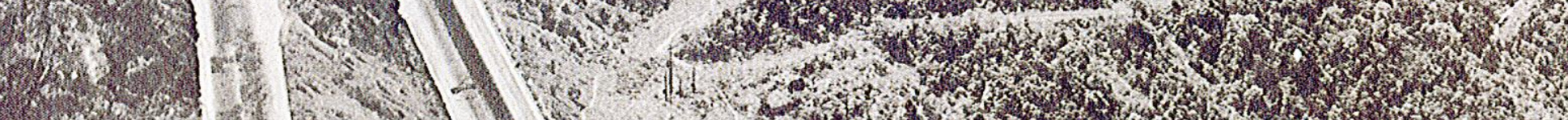

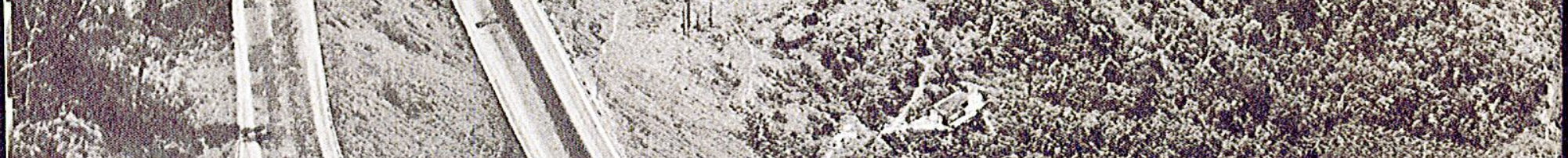

W.

1 H.t.

1
1

3. 0.63

1.2.

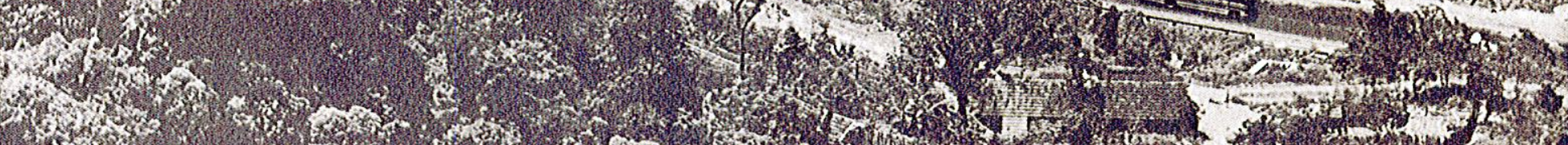

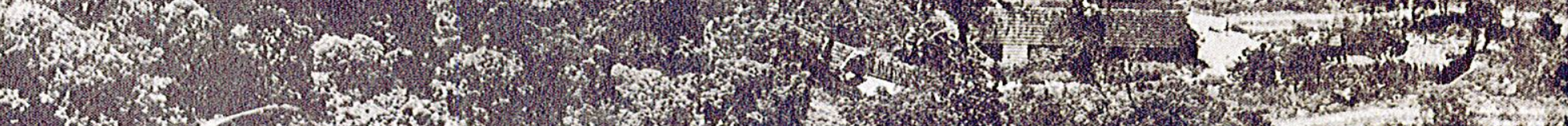

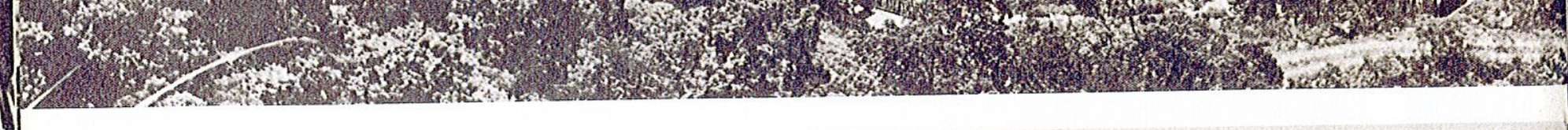

1.

Sin 3

ing

ming

Mng

Mxin

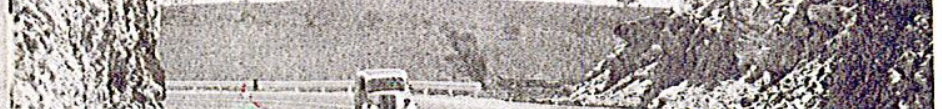

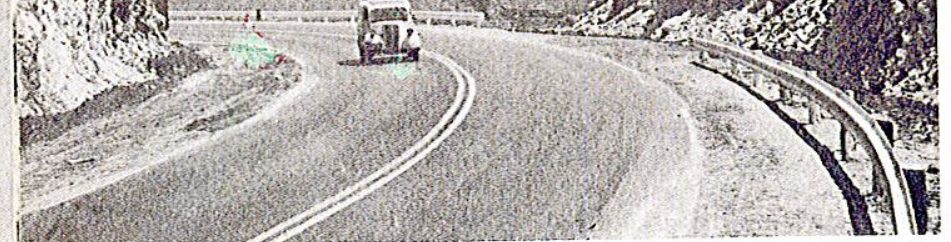

t.

1. Now

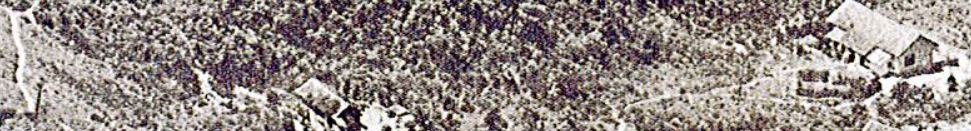
H.

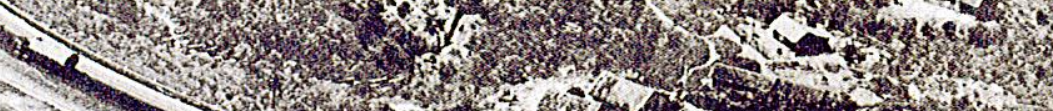
1.2.

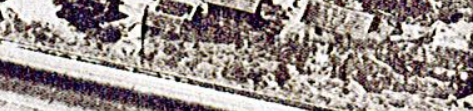

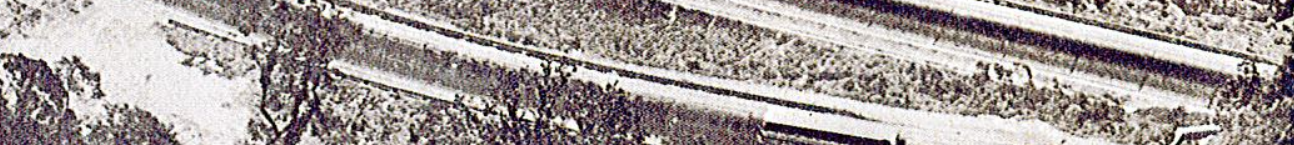
, 


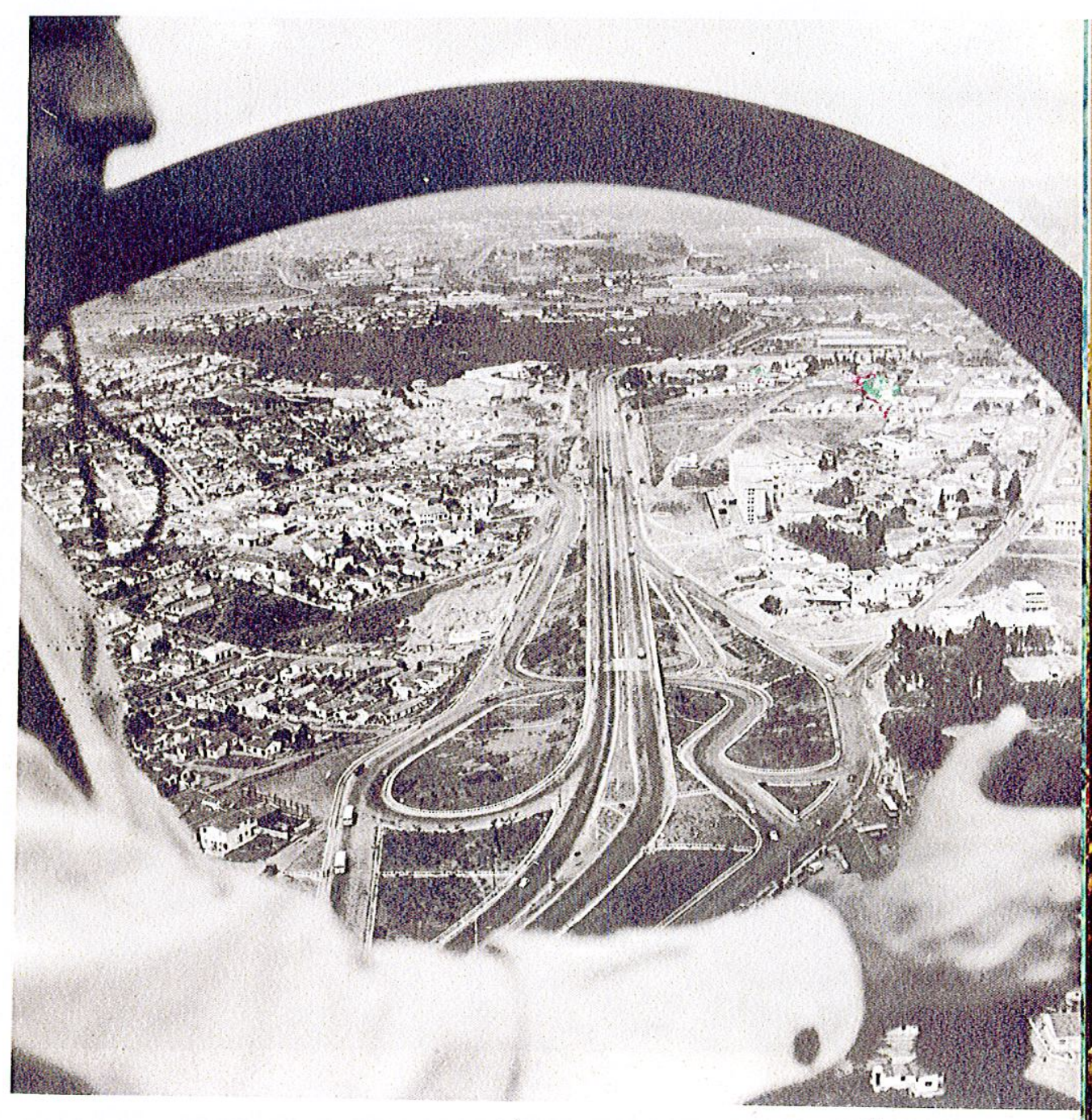

\section{Rodovias / Roddmuilding}

PRA ativar o povoamento do interior e a circulação de suas riquezas, um país de extensão quase continental exige rêde de comunicações cada vez mais ampla. Com 27 mil km de estradas de rodagem federais e estaduais pavimentados e $120 \mathrm{mil} \mathrm{km}$ não pavimentados, o Brasil está melhorando, duplicando e construindo amplas rodovias de penctração ou interligando áreas produtoras. De Norte a Sul os trabalhos prosseguem.

$\mathrm{N}$ order to populate the interior and to provide transportation for the nation's products, an almost continent-sized country like Brazil needs an ever-increasing highway network. With 16,800 miles of federal and state paved roads and 74,600 miles of unpaved, Brazil is going ahead with construction of new roads penetrating into new areas or linking production areas. From North to South this work is being improved in the country.

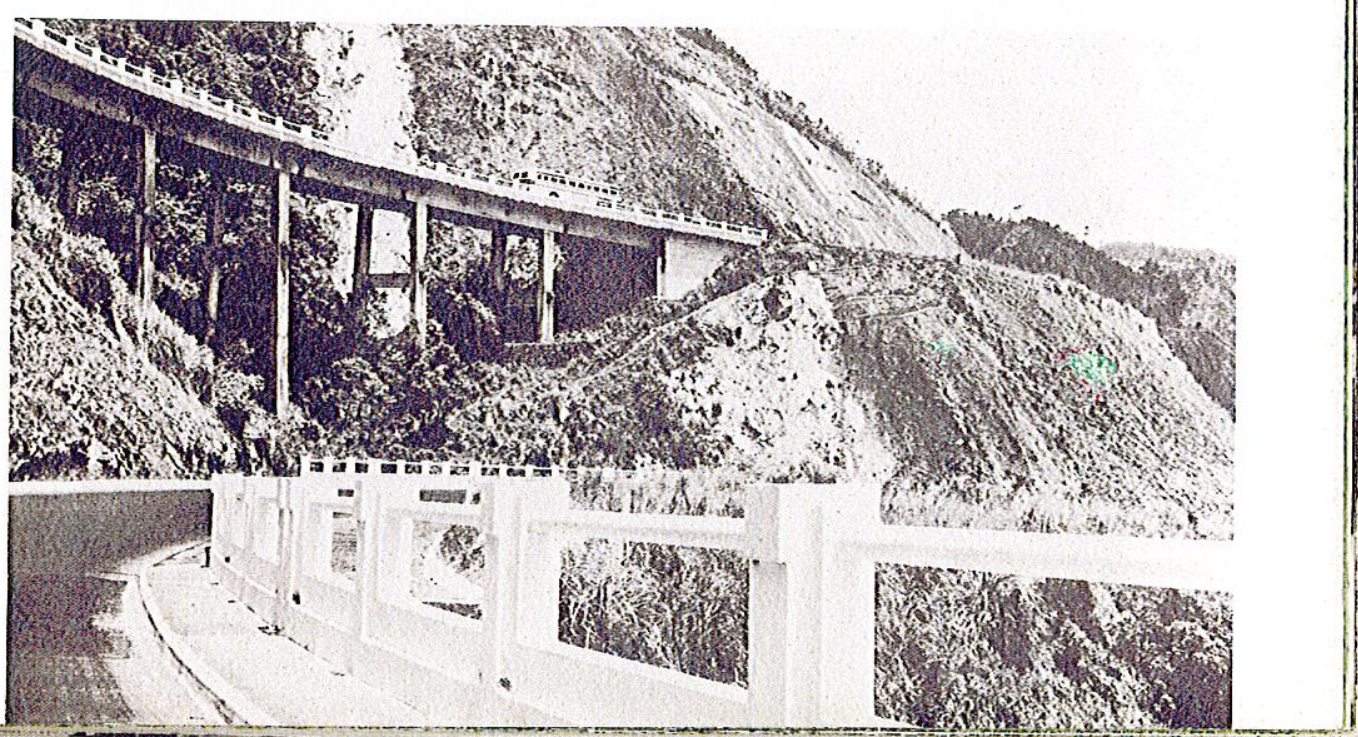




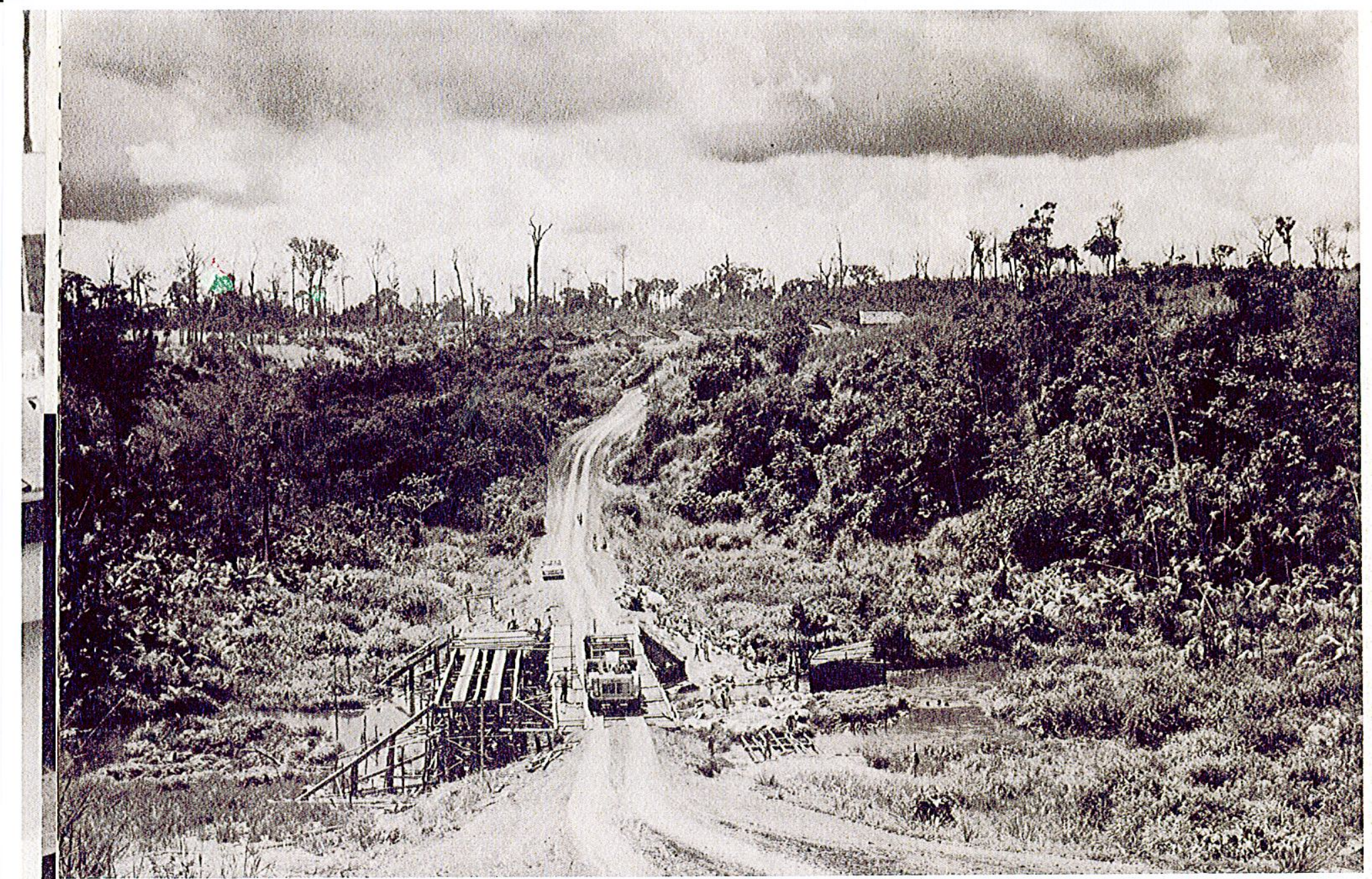

\section{uma estrada vence a selva This is Bellem - Brasilia}

A expansão da rêde rodoviária brasileira foi uma das conseqüências da construção de Brasília. Entre as gigantescas estradas planejadas para ligar a nova capital aos grandes centros do Norte e do Sul, a de mais difícil construção era a Rodovia Belém-Brasília. Com a extensão de mais de 2.200 quilômetros, varando a floresta amazônica e transpondo rios caudalosos, já é intensamente trafegada e, ao longo do seu traçado, surgiram, em poucos anos, dezenas de novas cidades.
NE of the results of building Brasilia was the expansion of the highway system. Of all the new roads to be built to connect the new capital with the rest of the country, the most difficult was the Belem-Brasilia. It is 2,200 kilometers long, cuts through Amazonian jungles and crosses great rivers. Traffic is heavy and dozens of new towns have sprung up along the roadside. These towns already contain an elementary school and health services.
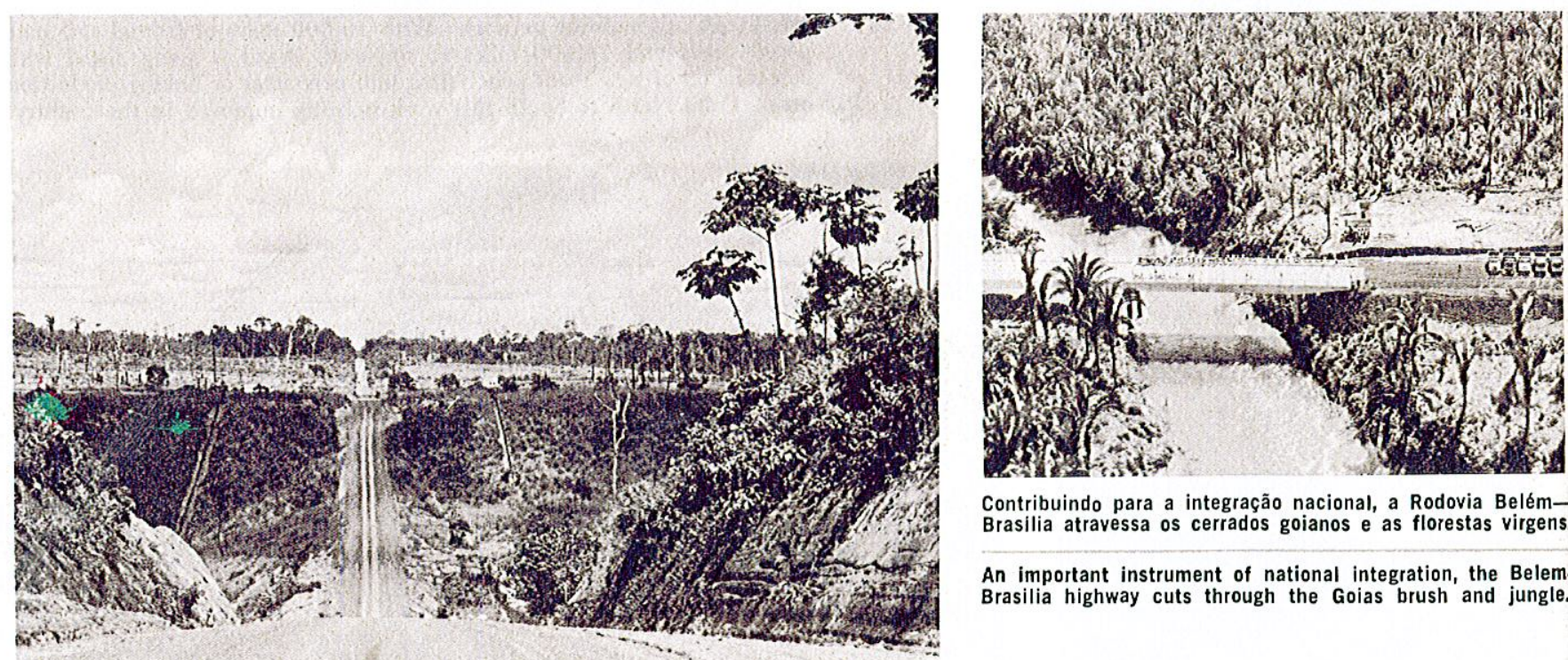

Contribuindo para a integração nacional, a Rodovia BelémBrasilia atravessa os cerrados goianos e as florestas virgens.

An important instrument of national integration, the BelemBrasilia highway cuts through the Goias brush and jungle. 


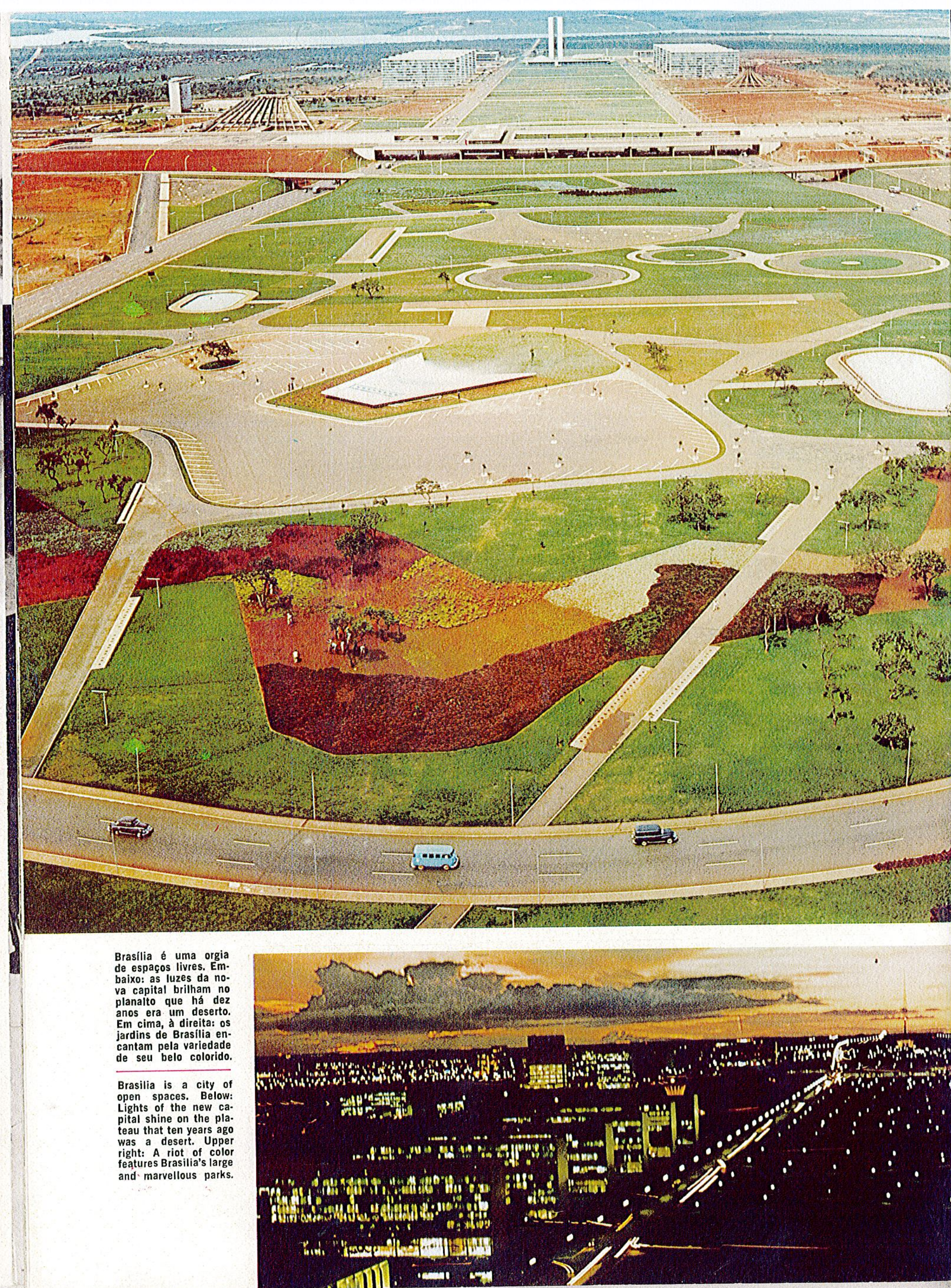



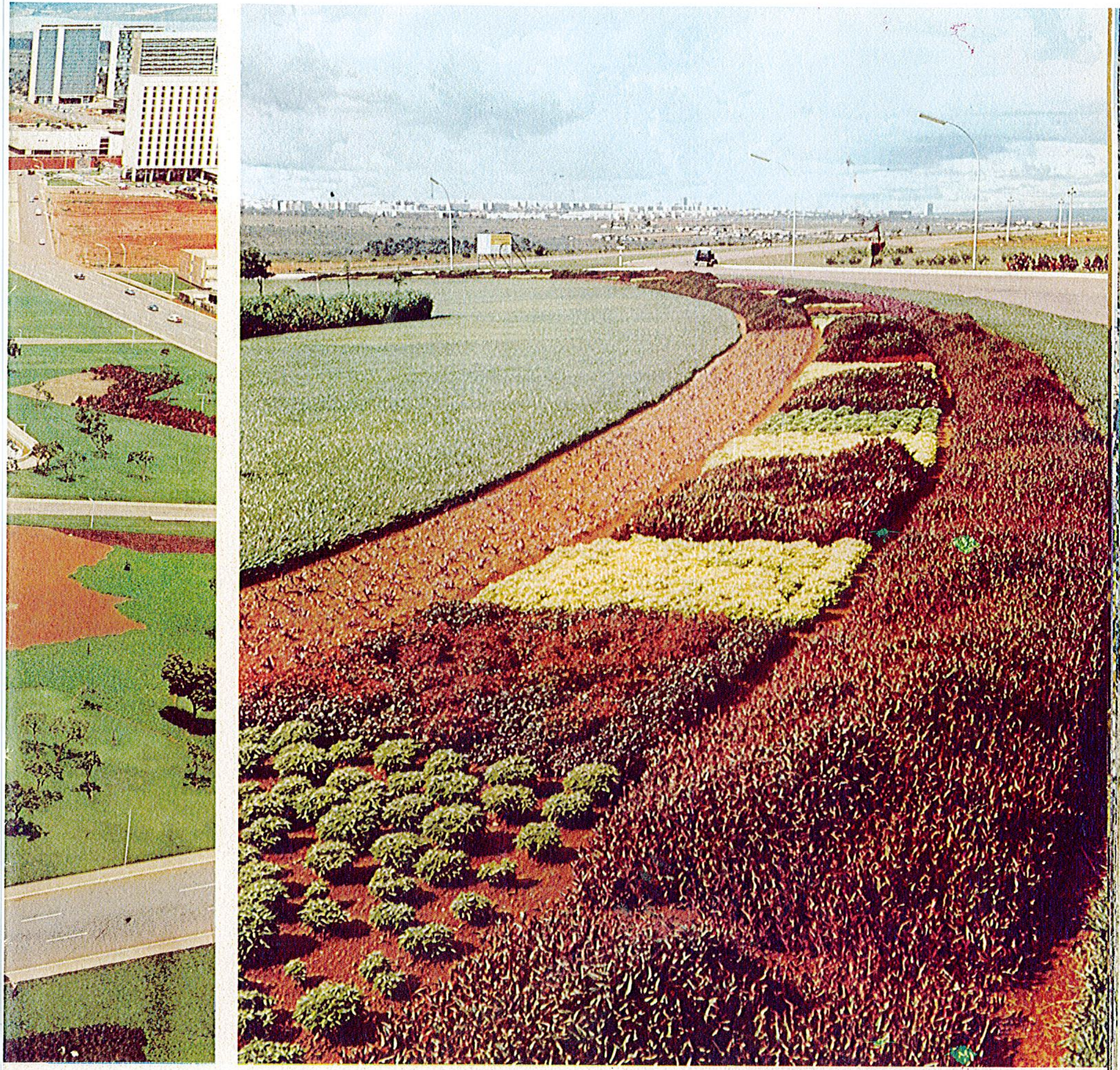

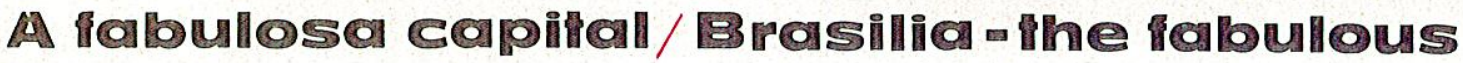

COM a construção de Brasília, o Brasil começou uma etapa nova de sua história: a da conquista do Oeste. Para o planalto central, foi levado, em 1960, o comando da nação. Dispondo de amplos espaços, urbanistas e arquitetos de renome traçaram praças e avenidas de amplitude sem paralelo, com áreas livres como não existem em qualquer outra cidade do mundo. Um sistema de tráfego sem a necessidade de sinais luminosos é outra de suas características. Brasília é, em todo o mundo, famosa por sua arquitetura, de estilo moderníssimo e original, anunciando de fato o século 21 .

BRAZIL entered into a new phase of history with construction of Brasilia, the inland capital. In 1960 the Government moved to this ultra-modern city built on an extensive plateau - miles inland from the heavily populated seacoast. Famous architects and city planners were given a free hand and the results were public squares and broad avenues - open spaces unparalleled in any other city of the world. A traffic system that works without stop lights is another unique feature of this city, famed throughout the world for its original architecture. 


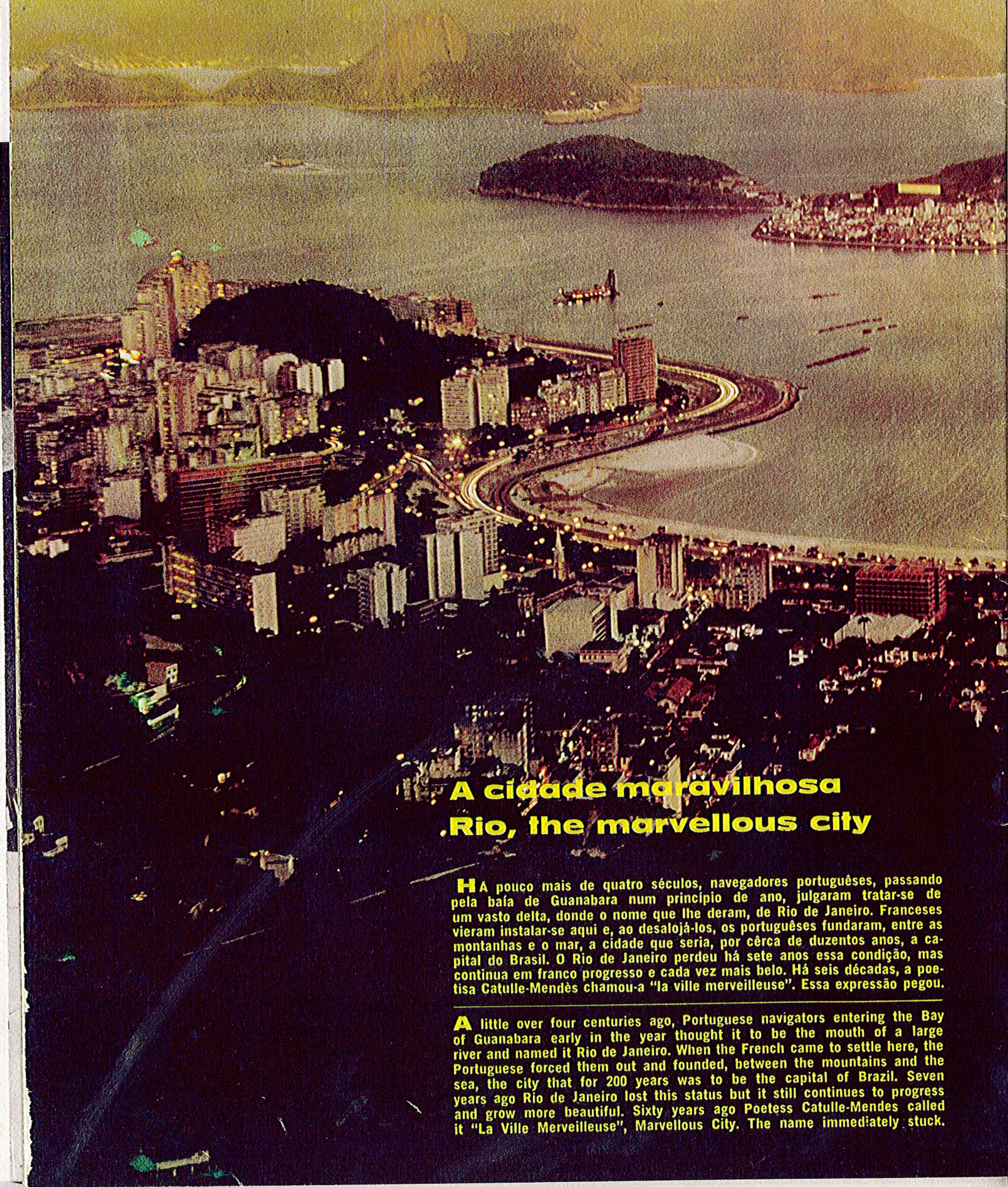





\section{o Rio se renova/The new face of Rio}

Rio de Janeiro cresceu tanto e suas vias se tornaram de tal modo congestionadas que foi preciso remover várias de suas montanhas e conquistar novas áreas, aterrando que foi preciso remores áreas, foi construido o Aeroporto Santos Dumont. Noutra, parte da baía. Numa dessas areas, foi construicto o Aroparas pardins e amplas pistas para o Muscu de Arte Moderna, o Nonumento dos Pracinhas, jardins e amplas pistas para o tráfego de veiculos. Emos históricos. Breve será construída uma ponte sòbre a baia.

R IO had grown so big and its streets become so congested that it was necessary to remore sercral of its mountains and build new areas by filling in part of the bay to remore sercral of its mount was butt. On another front. On part of this new area the Santos-Dument to the W'orld War If Dead. part the Museum of Modern Art andwars take up the rest of the filled in area. Rio is constantly changing and reminders of its past are only a few buildings and churches.
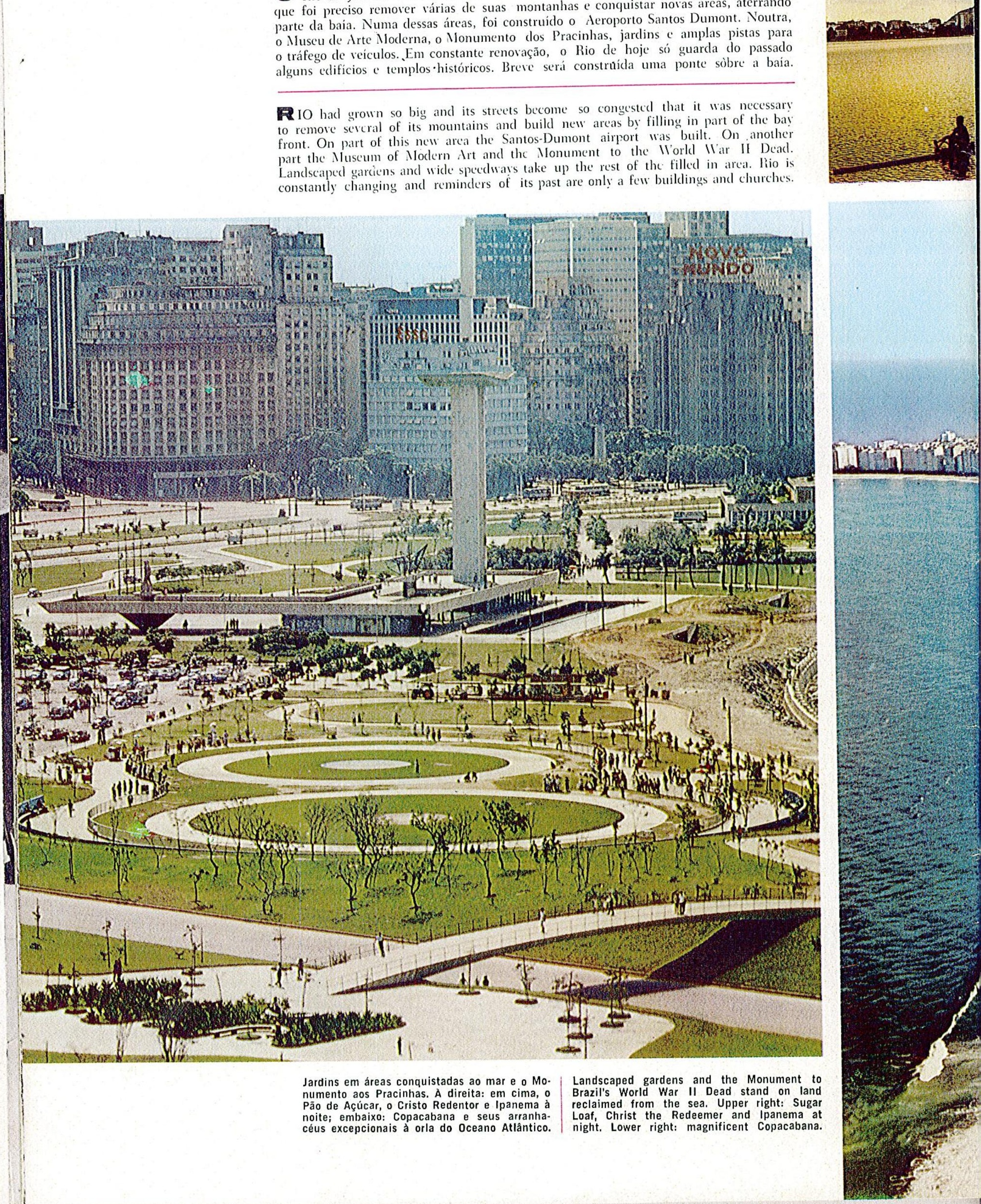

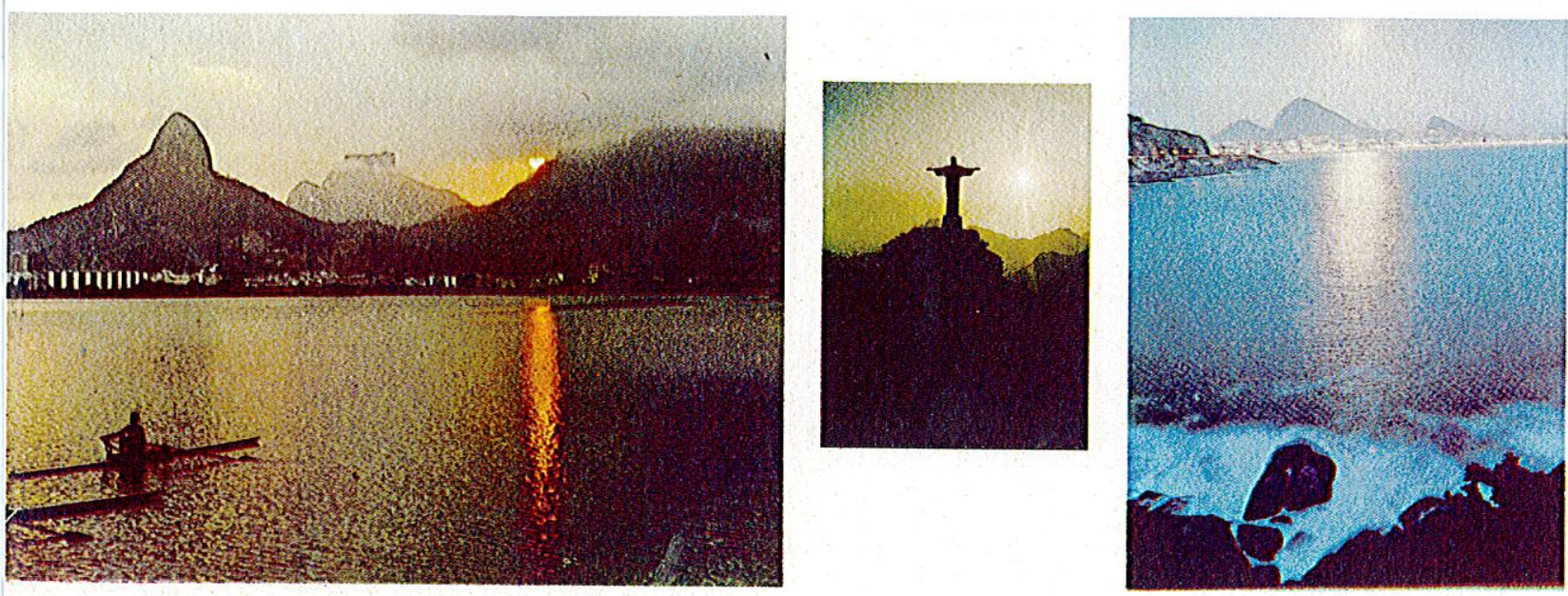

CIn 

(1) (1) (1)

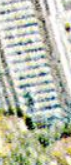
(1) (1)

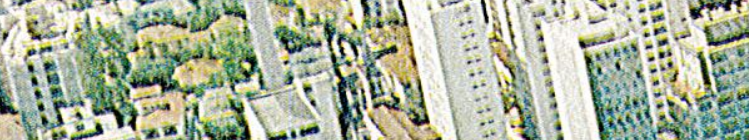

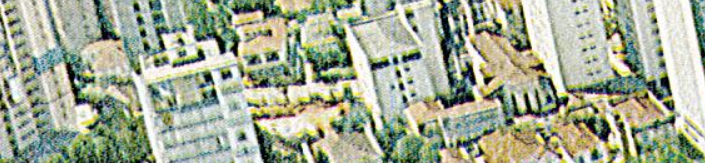
L- $-1-2$.

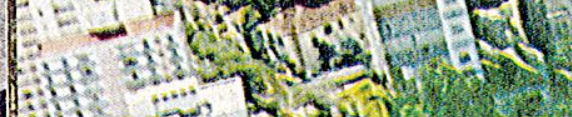

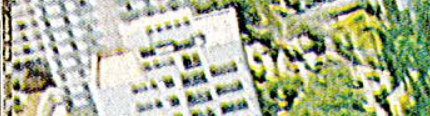

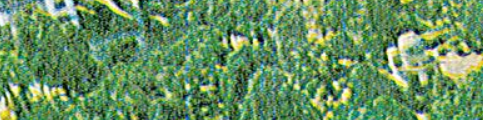

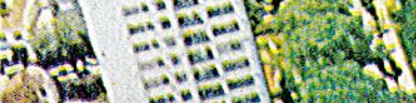

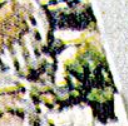

(4)

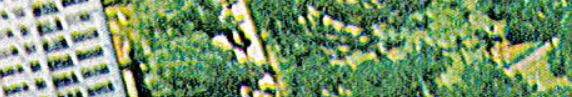

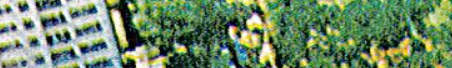

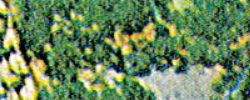

Lin sim
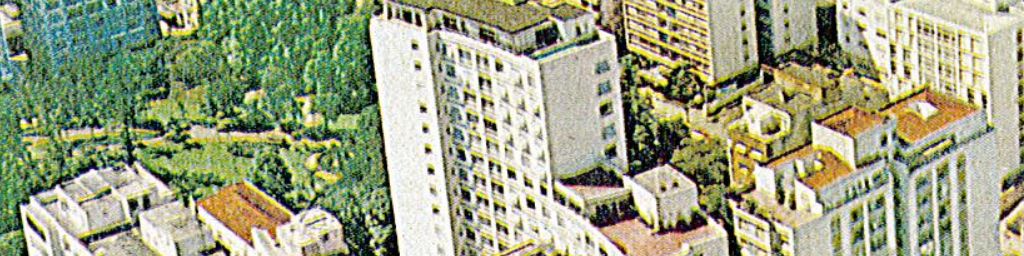

(1)
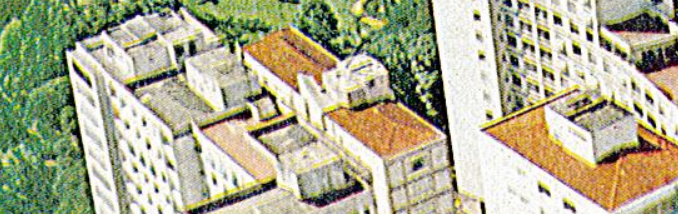
Tin

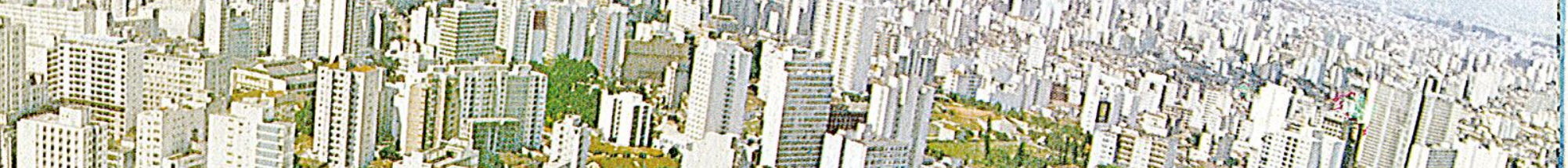
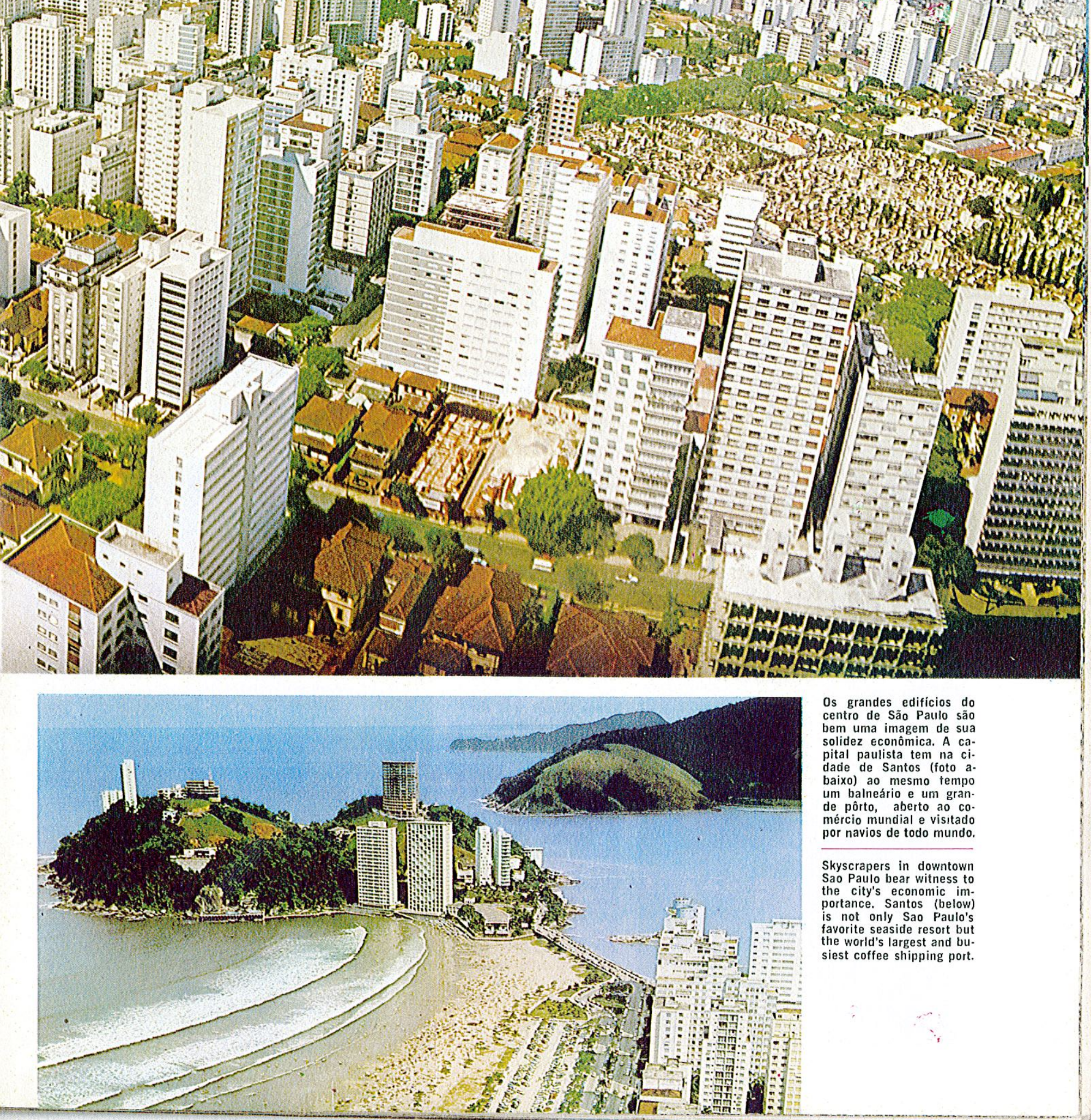

Os grandes edifícios do centro de São Paulo são bem uma imagem de sua solidez Econômica. A capital paulista tem na cidade de Santos (foto abaixo) ao mesmo tempo um balneário e um gran. de pôrto, aberto ao co. mércio mundial e visitado por navios de todo mundo.

Skyscrapers in downtown Sao Paulo bear witness to the city's economic importance. Santos (below) is not only Sao Paulo's favorite seaside resort but the world's largest and busiest coffee shipping port. 

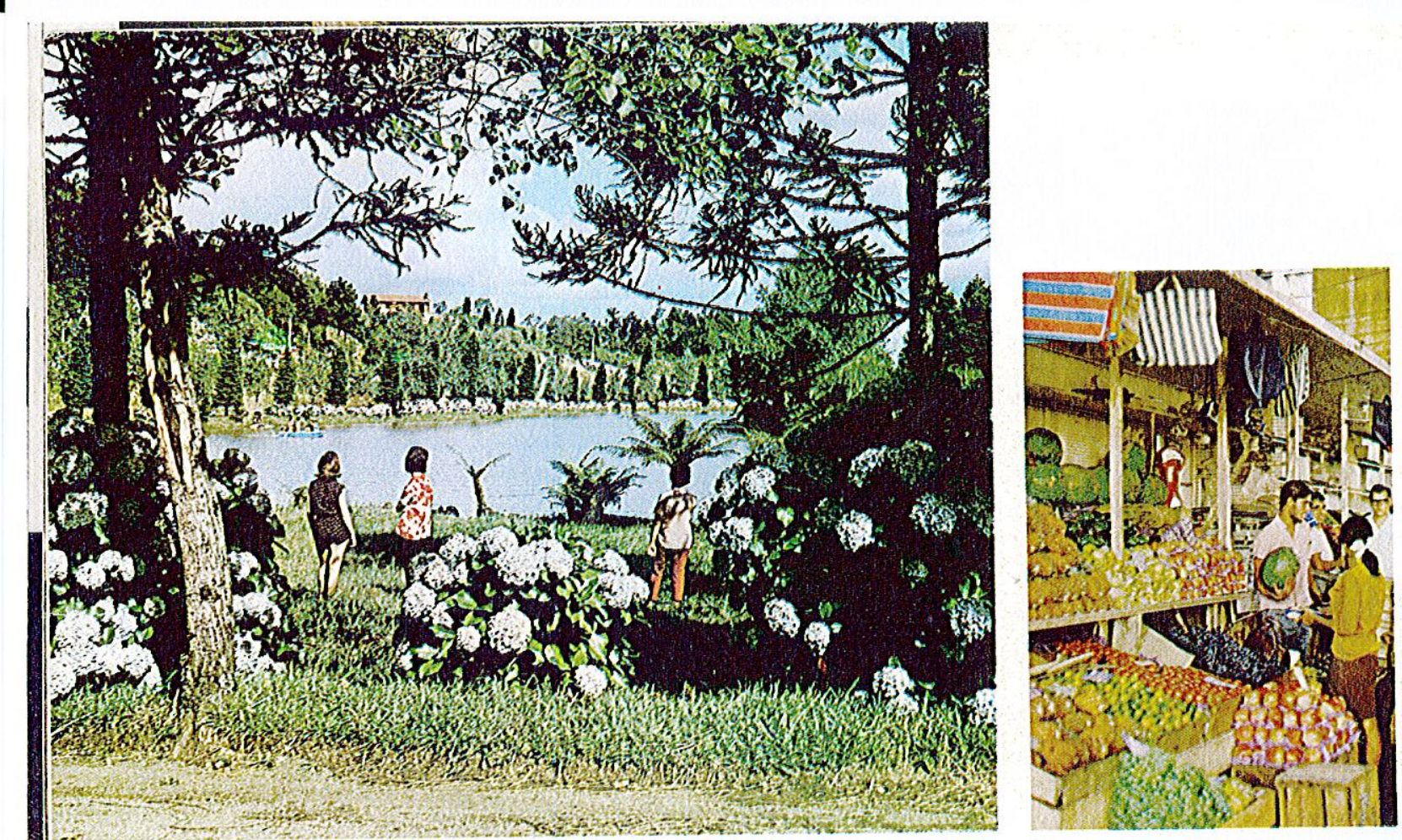

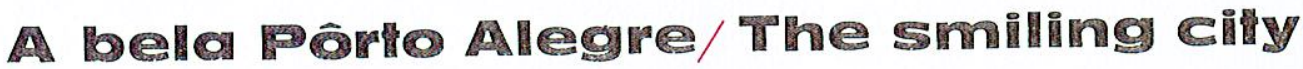

A LeN de sua riquéza pecuária, o Rio Grande do Sul tem importantes indústrias e uma desenvolvida agricultura. Condiçōes geológicas e climáticas o aparelham a produzir trigo, milho, soja ce outros cereais, além de uvas em quantidade suficiente para abastecer poderosa indústria vinícola. Alguns de seus vinhos estão sendo exportados com expressivo sucesso para os Estados Unidos e a Europa.

IN addition to its great herds, Rio Grande do. Sul also has important industrie and flourishing farmlands. Due to its climate and soil, Rio Grande produces wheat, corn, sorbeans and other grains as well als grapes enough to supply a large wine industry. Some Rio Grande wines are being exported with stecess.

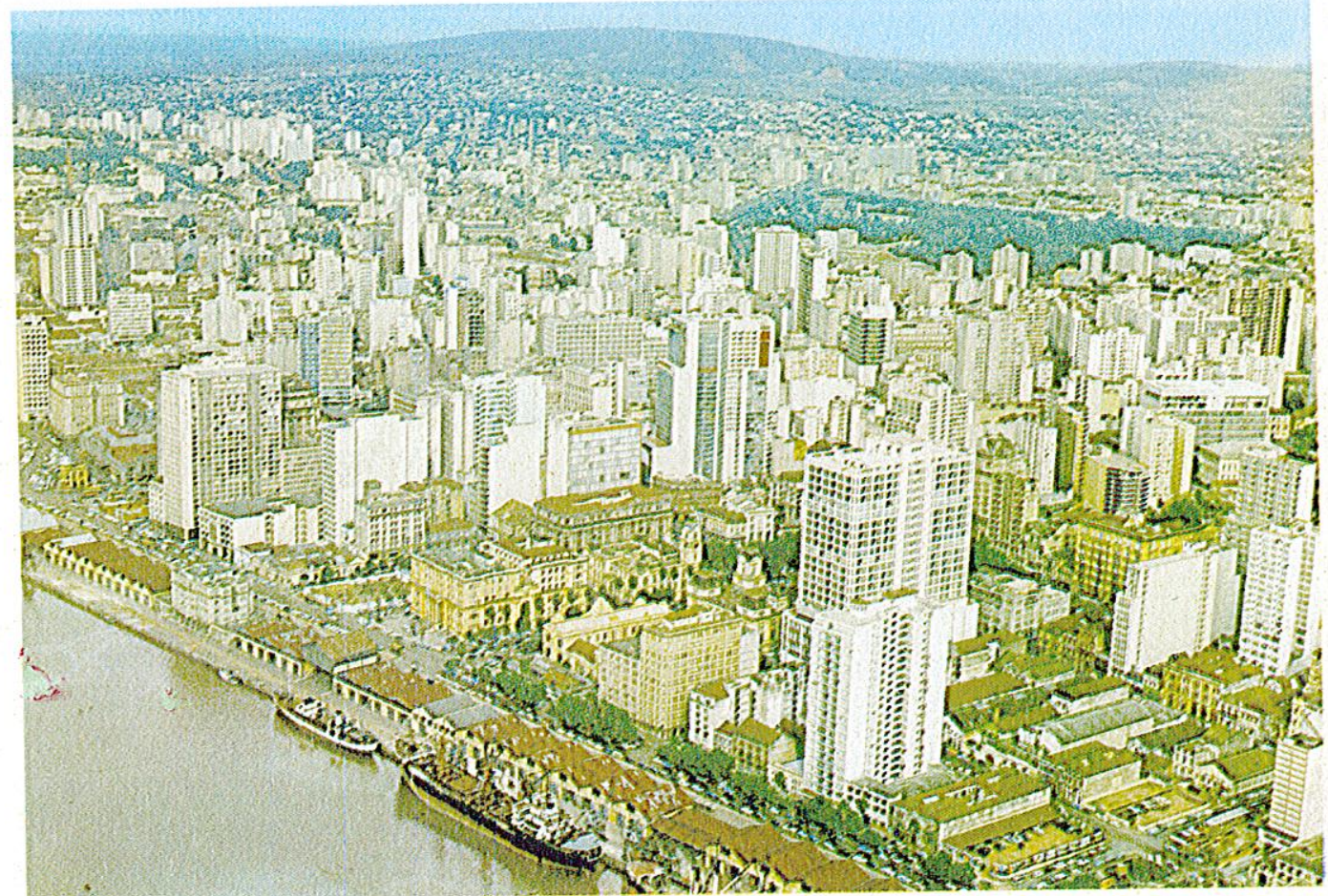

Pôrto Alegre é uma cidade moderna e progressista, com

Porto Alegre is a modern and progressive city with beautiful belos parques e mercados bem abastecidos (fotos ao alto). $\quad \begin{aligned} & \text { parks and well stocked markets (top). Upper right: the } \\ & \text { Gaucho (Rio Grande cowboy) and the plains; lower right: }\end{aligned}$

parks Alegre is a modern and progressive cily with beautiful

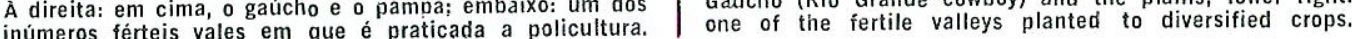

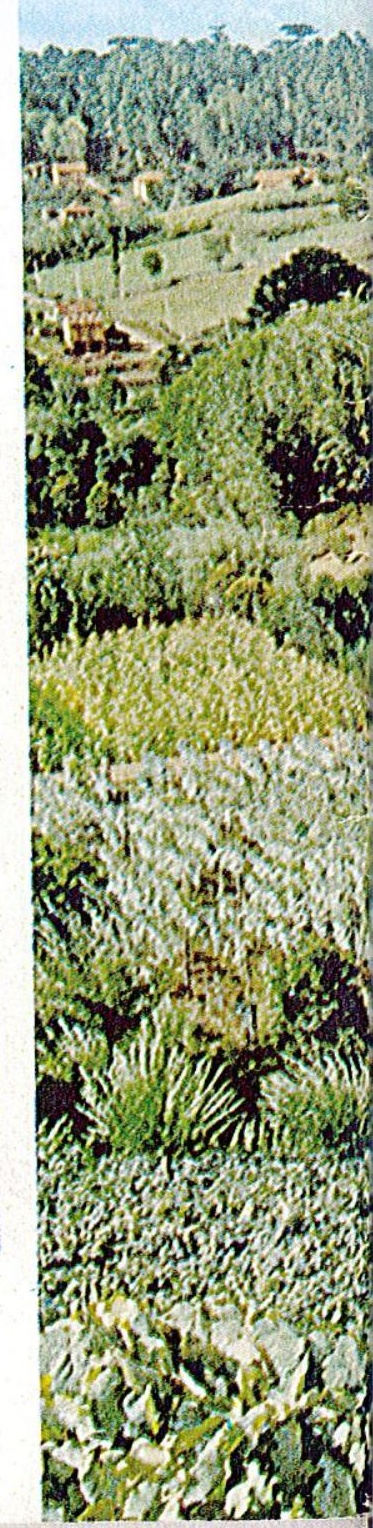




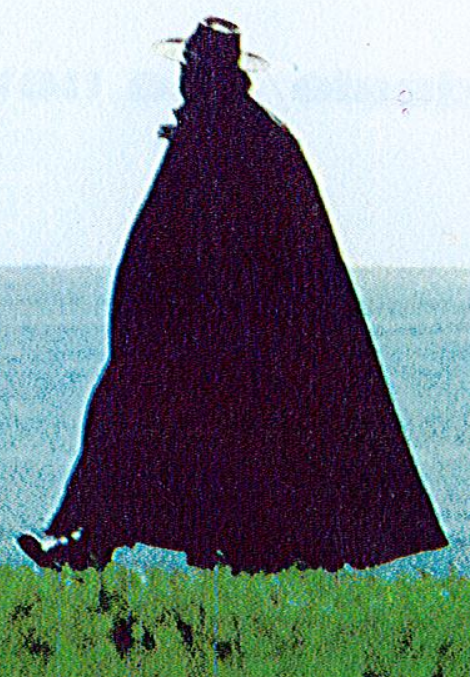

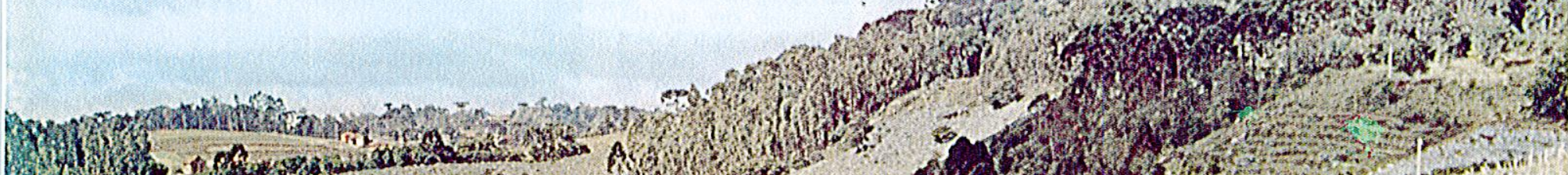

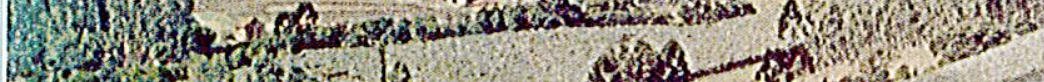
H.

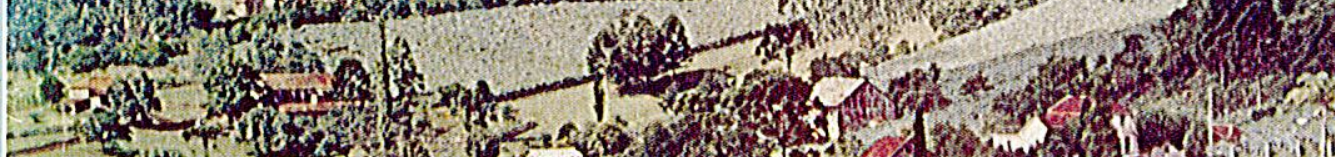

-

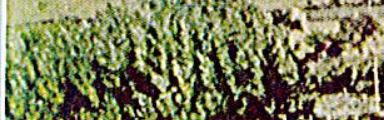

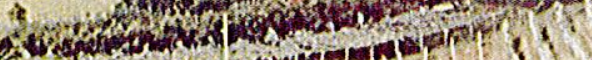

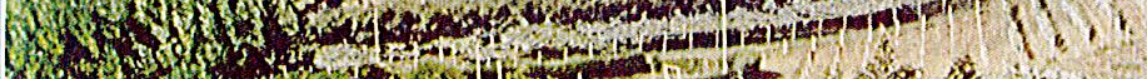
(6)

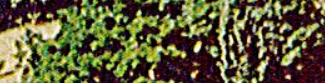
(1)

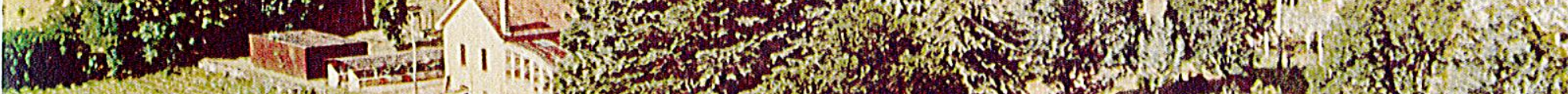

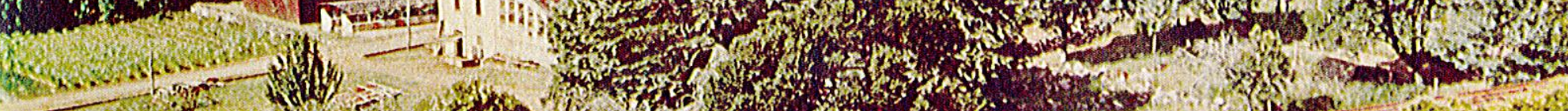

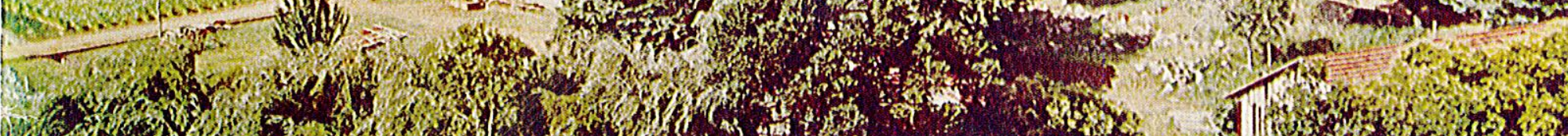

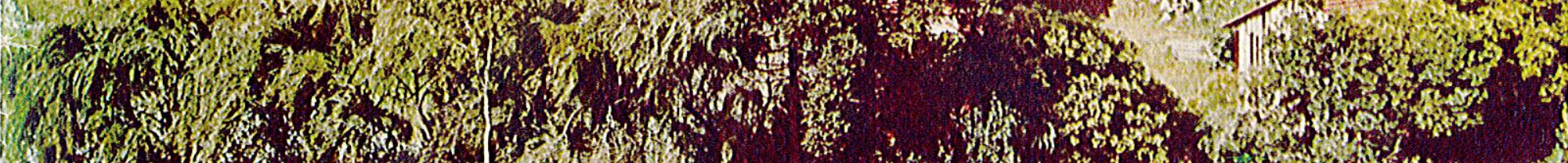
8.

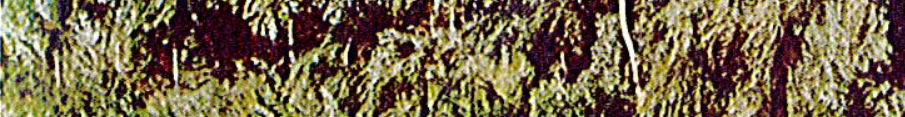
(1)

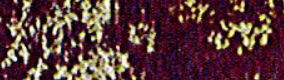

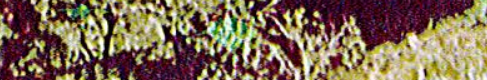
txing 30 .

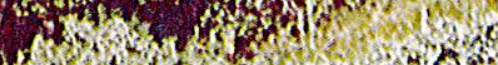

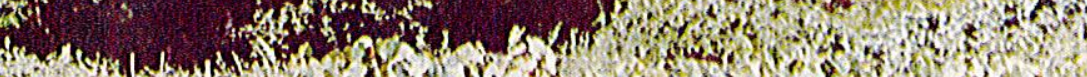

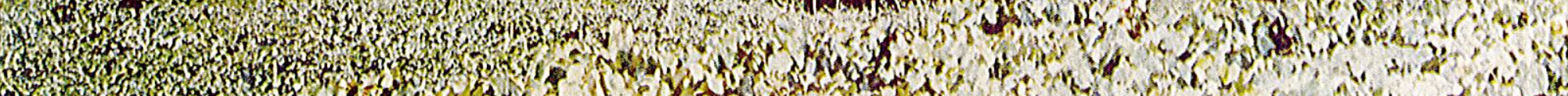

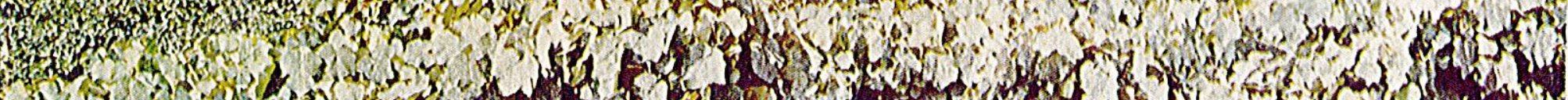

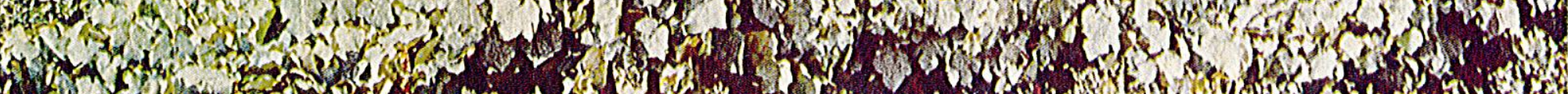
167. axt 
Nôvo Nordeste/The new Northeası

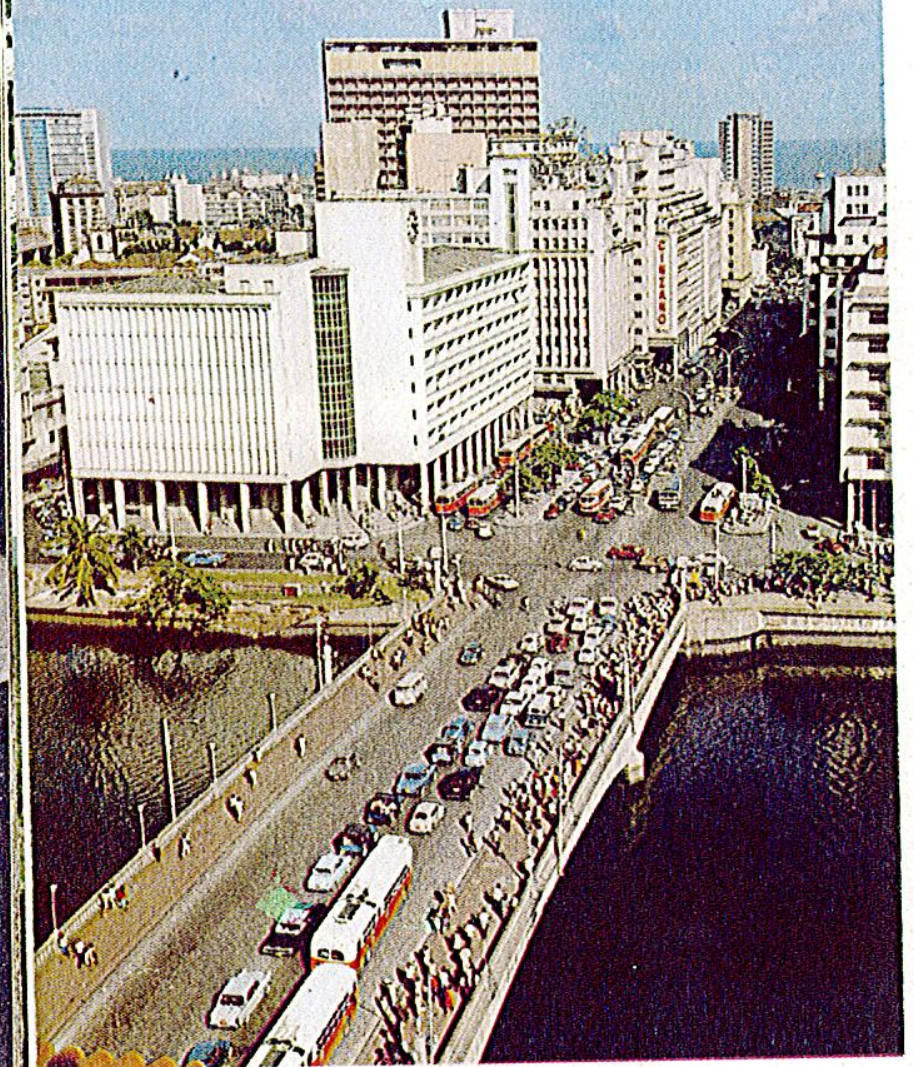

No Nordeste, que hoje atravessa um período de desenvolvimento, graças a uma política de estímulos fiscais e investimentos maciços, Recife é a cidade mais importante. Cortada pelo Capiberibe e Beberibe, por suas numerosas pontes, recebeu a denominação de Veneza Brasileira. A esquerda e à direita, dois aspectos de Recife, capital de Pernambuco, hoje um importante centro in dustrial e que dia a dia se torna mais moderno.

RECIFE is the most important city in the Northeast which is now undergoing a period of development thanks to a policy of tax exemptions and massive investment. Cut as it is by the Capibaribe and Beberibe rivers and their numerous bridges, Recife has been nicknamed the Venice of Brazil. The pictures on the left and right show two aspects of Recife, Capital of Pernambuco, today an important industrial cen ter and growing daily.

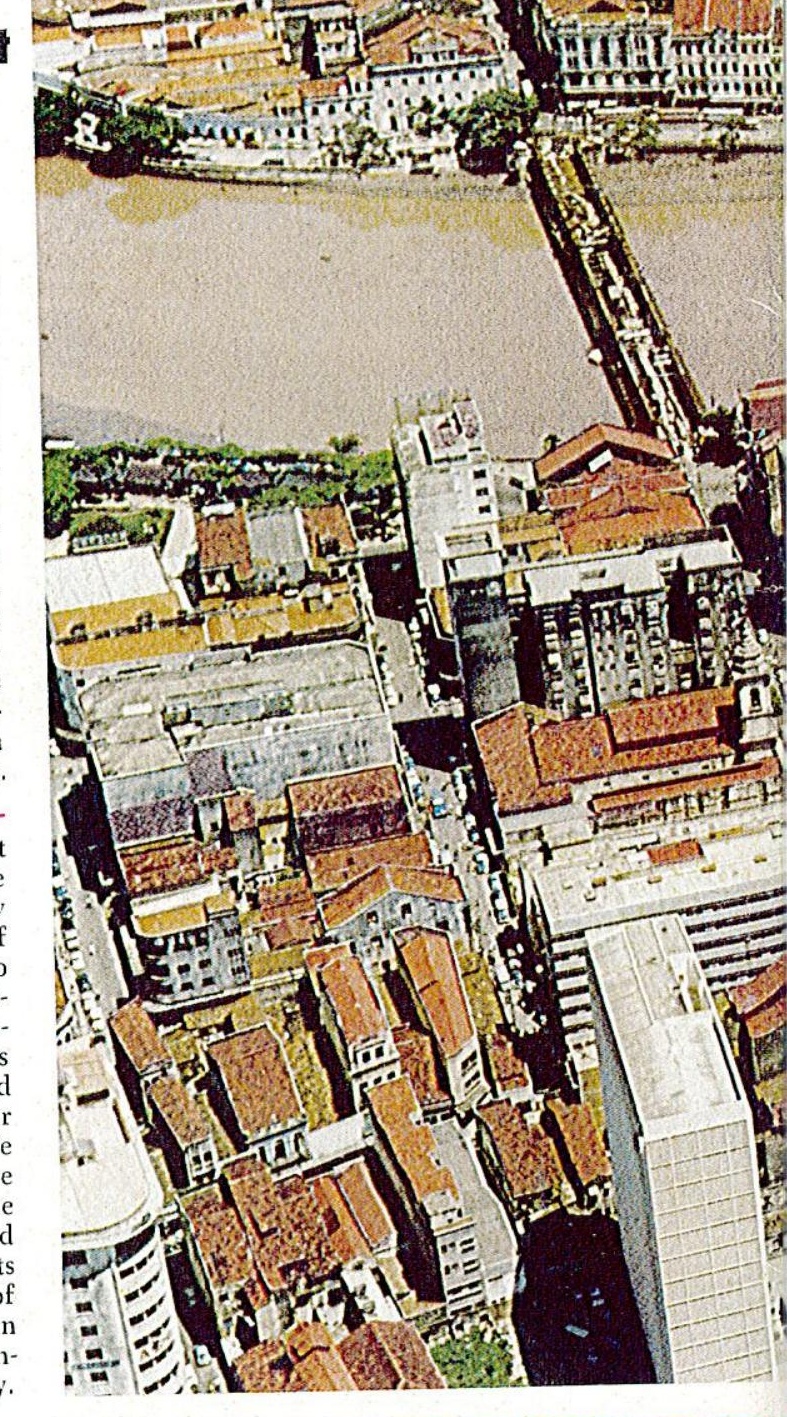

\section{Encanto baiano/Charming Bahia}
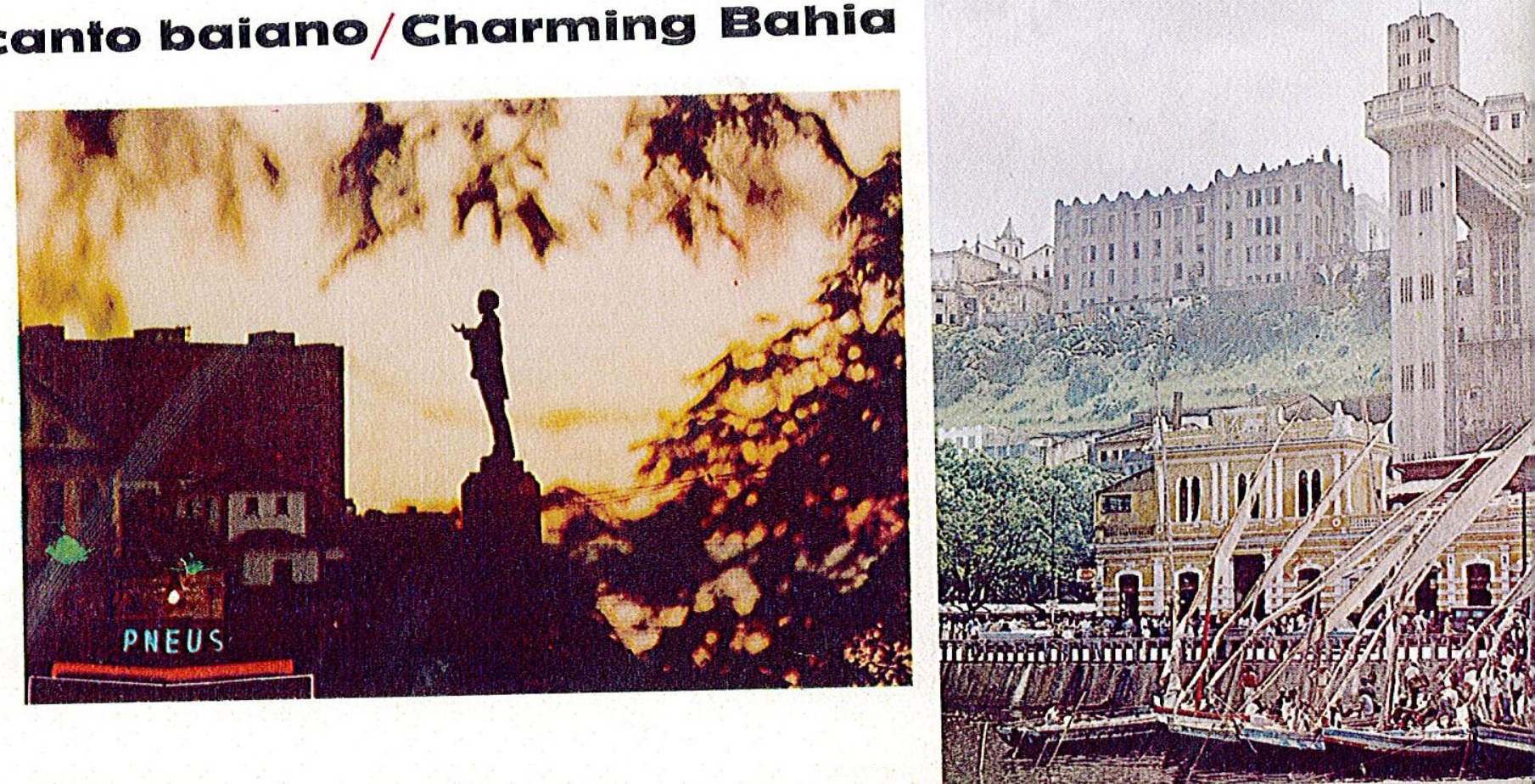


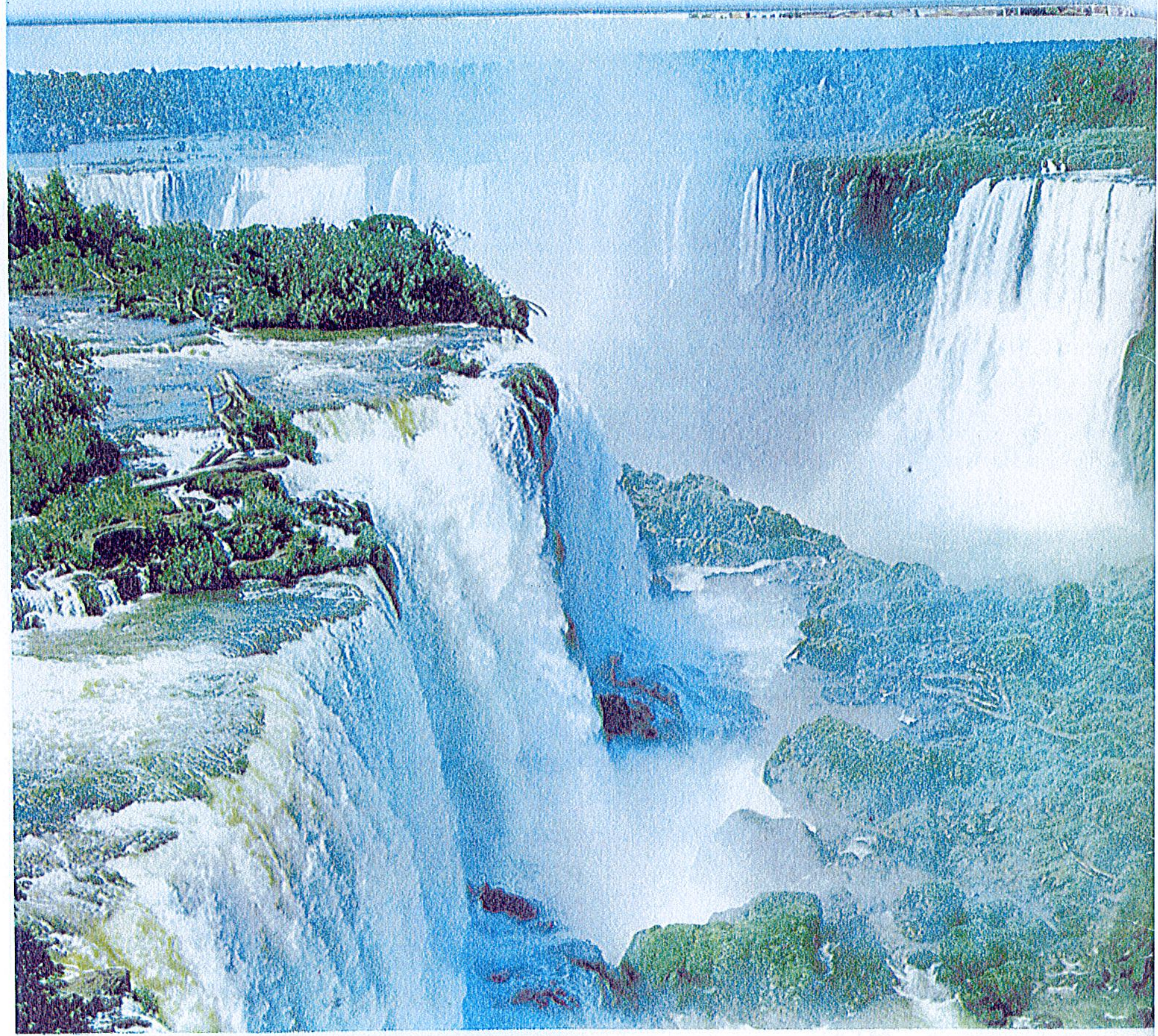

Foz do Iguaçu, excepcional maravilha turistica do Paraná

Iguaçu Falls, magnıficent tourıstic resorc in the State of Paraná.

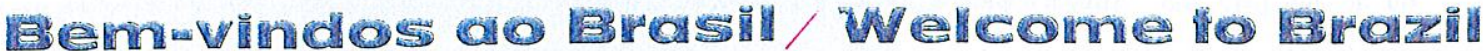

12 EIXO, aqui, un convite dirigido aos ilustres visitantes, que nos hontam com a stua presença. E uma exortação para que vejam e conheçam o Brasil, nação que apresenta desconcertantes e bizarros aspectos de singularidades físicas e geográficas. Fm Salvador, vemos uma cidade colonial ao lado de una refinaria uhramodema, como Mataripe. No Estado do Rio, temos montanhas que apontam para o céu, ao lado de praias com águas cristalinas. Ao Sul, a terra se estende na planura das savanas, poveadas por milhōes de eaheças de gado, enquanto ao Norte - Amazonas of́erece o espetáculo de uma regiāo misteriosi, ainda não penetradia pelo homem. Mas o Brasil não é apenas paisagem e clima. É, também, esfồç̧o criador e realização técnica - centrais elétricas, lavoura mecanizada e indústrias de todos os tipos. E um país jovem e audac que saltou da era da traçăo animal para a era eletrònica, ignorando os clos clássicos da evolução. Isto foi possivel peio gènio empreendedor de seus habitantes e pelo inconformismo de sta raça. Guardamos intacta uma cidade-relicário como Ouro Prèto e construimos, em tempo recorde, a fabulosa Brasilia. Todos èsses aspeetos devem ser vistos, medidos pensados, como fatòres de una nova filosofia de desenvolvinento. E, para que essa caref́ta possa ser realizadi, o govèno criou a EMBRATUR, que irá industrializar o turismo. Venham conhecere o Brasil!
7HIS is an invitation to our distinguished guests to see and oct to know Brazil, a nation of surprising contrasts and physical and geographical singularitics.

In Salvador we have a colonial city alongside a modern refinery like Mataripe. In the State of Rio de laneire we have mountains reaching for the sky alongside beaches bathed by crystaline waters. In the Sotih the plains stretch for miles, populated by milions of head of cattle while in the North the Amazon reoion holds a mysterious area where man has never stepped. But Brazil is not just seenery and climate. It is also a creative effort towards technical achievements - power plants, mechanized agriculture and industries of all kinds. It is a young and daring country which skipped from the horse-and-buggy era to the clectronic ignoing the classic links of erolution. This was made possible by the venturesome temperament of its people and the non-conformity of otir race. We heep intact a reliquary city like Ouro Preto while constructing a Brasilia in record inme. All of these facets should be secen, measured and considered as factors of a new development philosophy. For this reason the Government created EMBIAATUR, which will industrialize tourism. Come meet Brazil! 


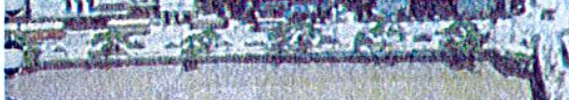

\section{3}

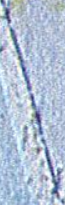

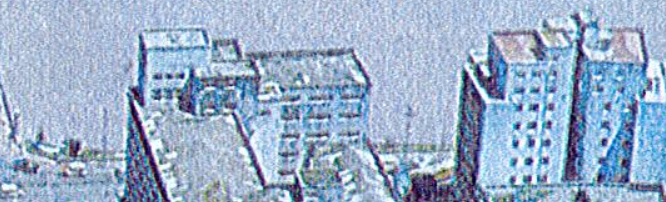

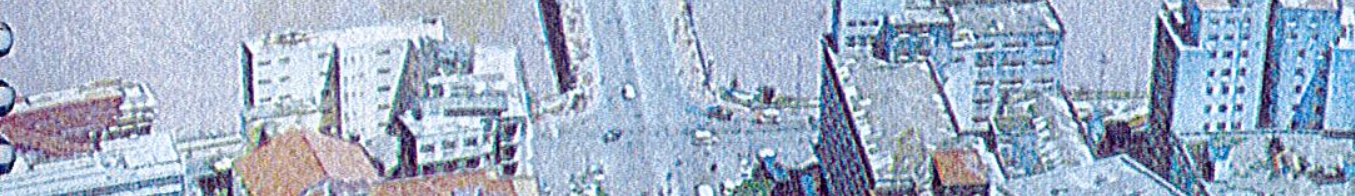

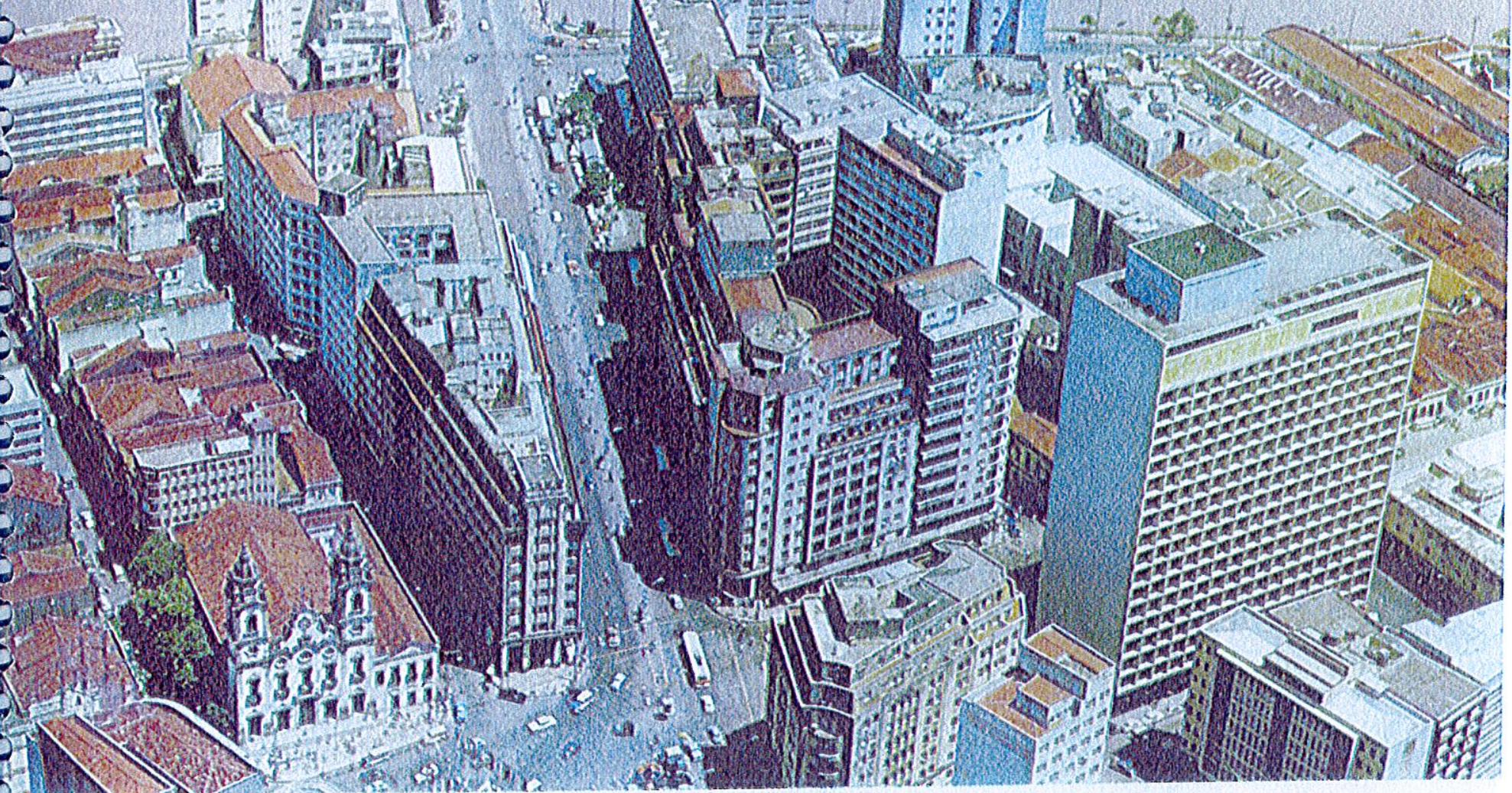

\section{5}

$?$

N 1 Bahia, a orande riqueza cra o acau, até que ali sc descobriu n petrólco, cuja produçăo $\mathrm{vem}$ aummentan do de ano para ano. Intiga capital do Brasil - antes do Bio de Janciro de Brasilia --. Salvador é uma cida"de pitorescal, mistura de arquitetura 1.8.

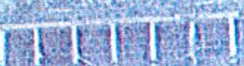

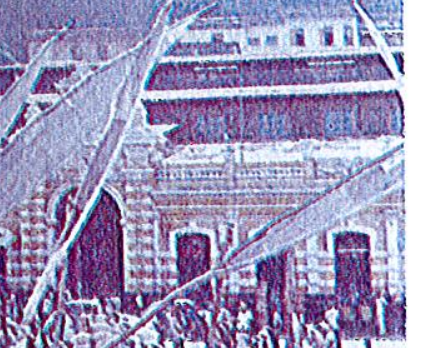

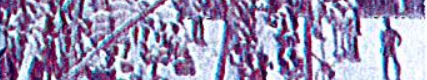

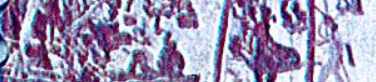

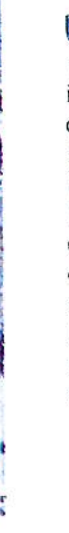

Uf N TIL nil was discovered, cacan

"ras the principal source of $B$ ahias

duction has been increasing steadils.

Before Rio de Janeirn and Brasilia.

It is a picturesque rits, a misture of

churches and colonial homes. The

novels of Brazil's best known writer,

capital of Bahia (left). At right is seen the white and blue Nbacte Lake.

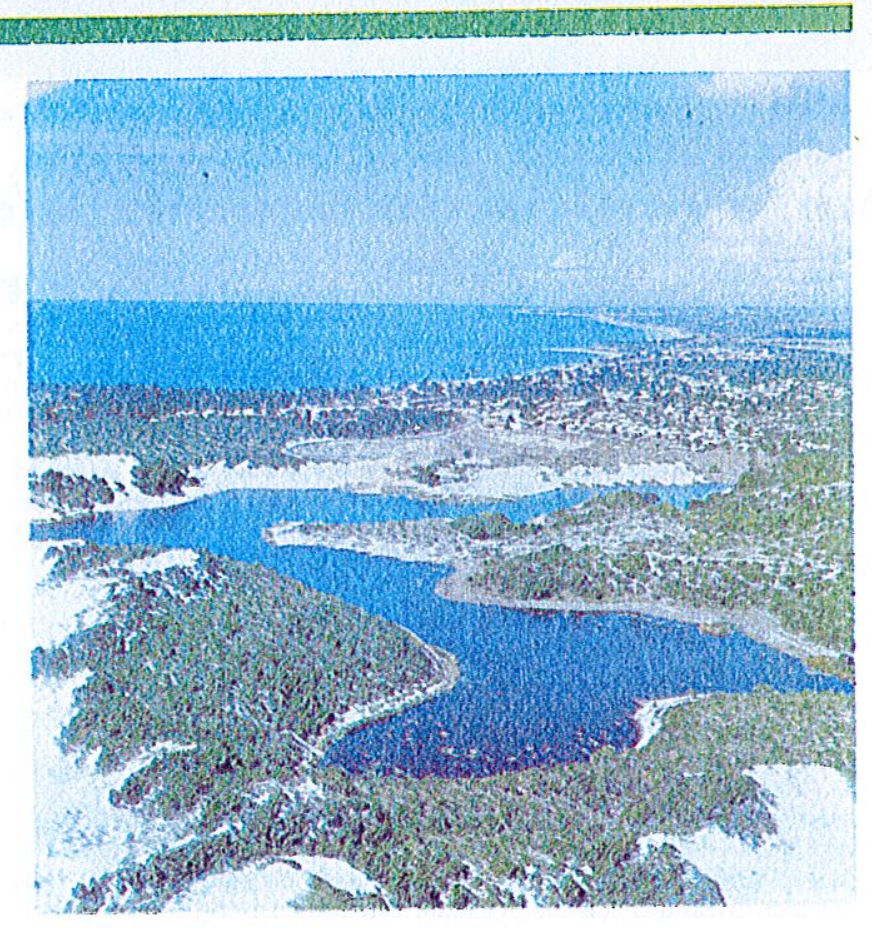


Este trabalho foi elaborado pela Emprêsa Brasileira de Turismo (Embratur), vinculada ao Ministério da Indústria e do Comércio. Avenida Presidente Vargas, 435 $130^{\circ}$ andar - Estado da Guanabara

This work was made by Emprêsa Brasileira de Turismo (Embratur), connected with the Ministry for Industry and Commerce. Avenida Presidente Vargas, $435-$
$130^{\circ}$ andar - Estado da Guanabara

Impresso e editado por Printed and edited by

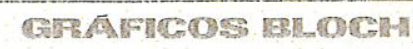

Rua Frei Cancca, 511 Estado da Guanabara 


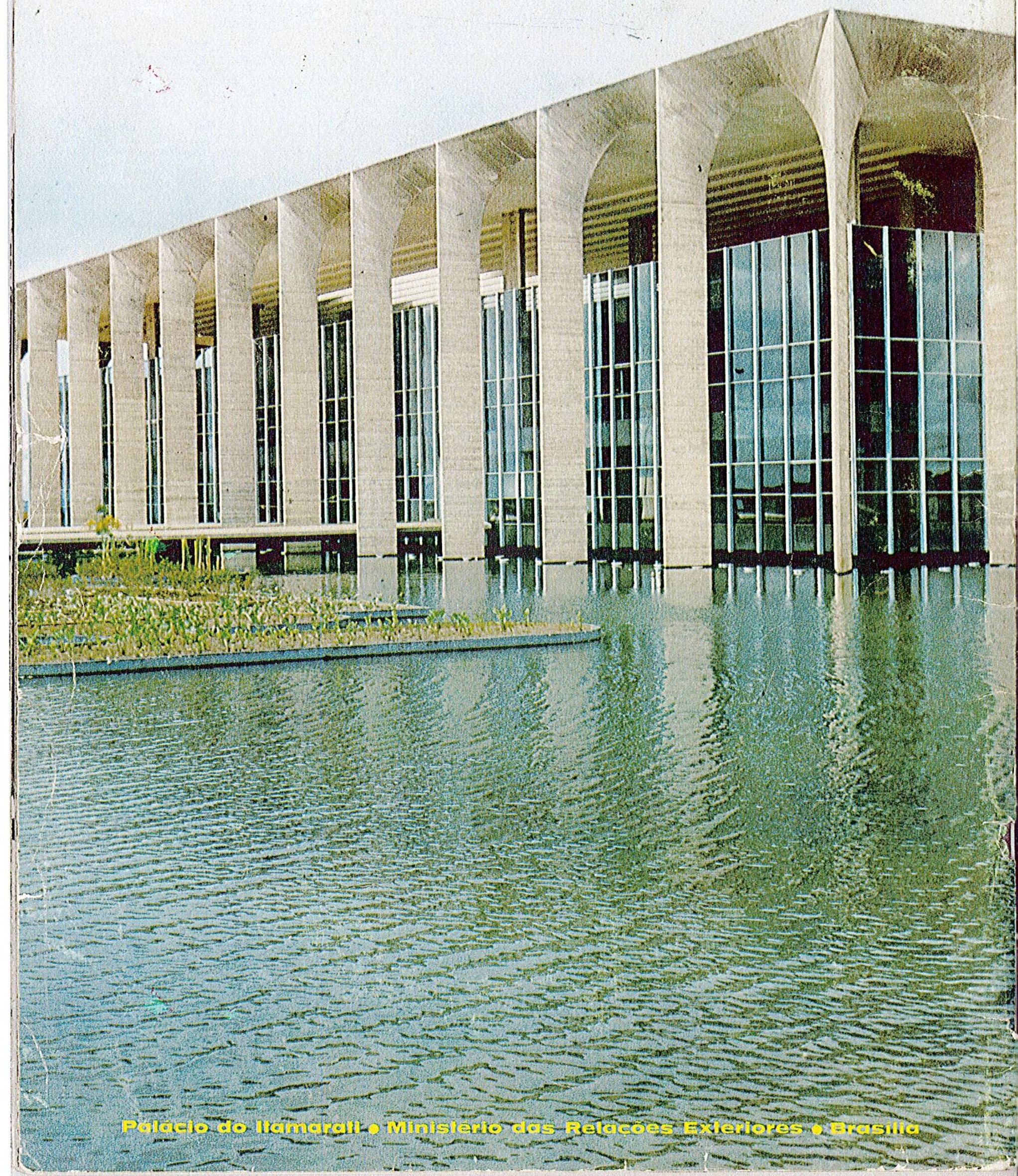


ANEXO VI

Foto do edifício sede no Rio de Janeiro 


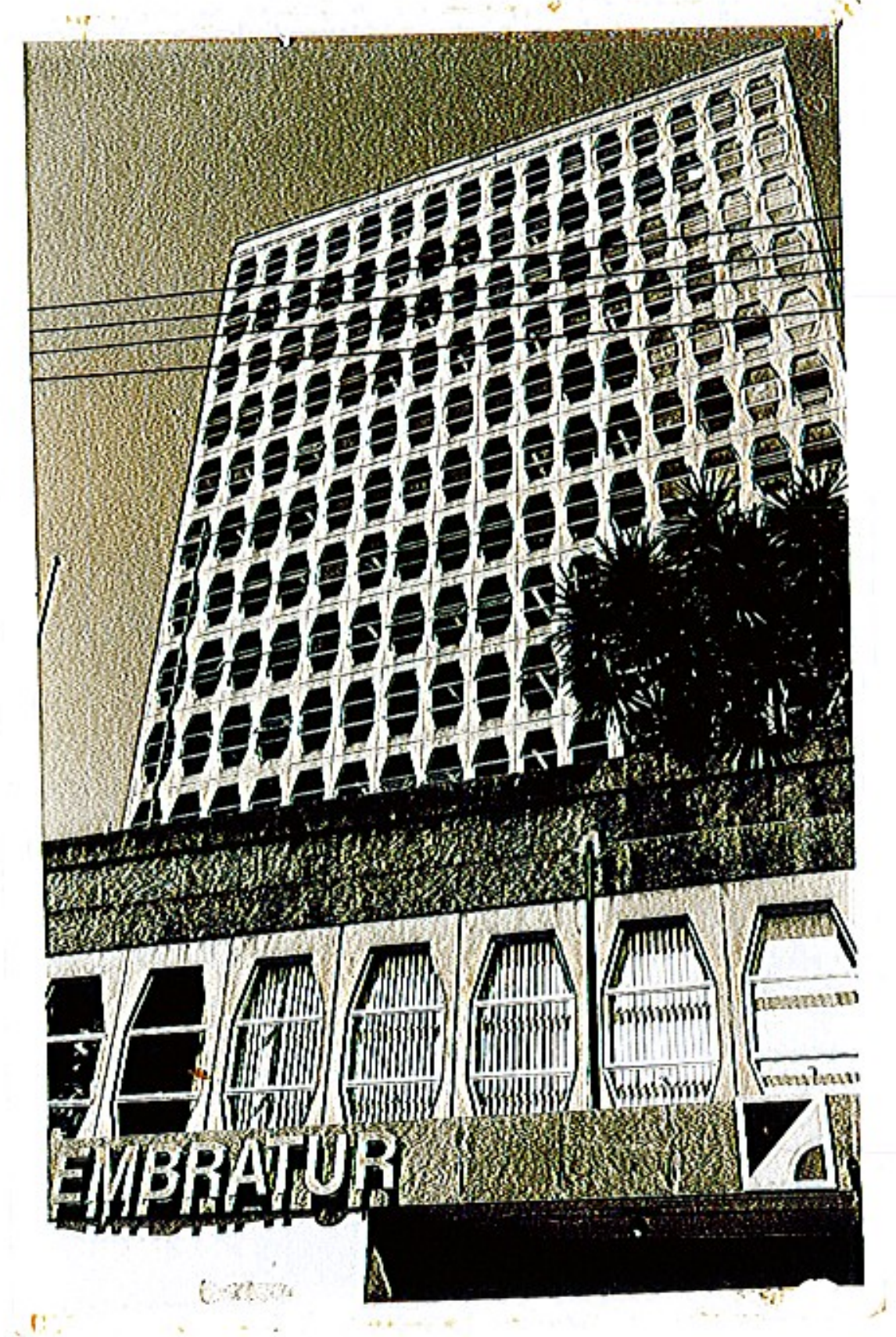


ANEXO VII

Resultados Turismo no período de 1966 a 2006 
Evolução do Turismo Mundial - 1966 - 2004

\begin{tabular}{|c|c|}
\hline ANO & $\begin{array}{l}\text { CHEGADAS INTERNACIOAIS } \\
\text { (EM MILHÕES DE TURISTAS) }\end{array}$ \\
\hline 1966 & 120,00 \\
\hline 1967 & 129,80 \\
\hline 1968 & 131,20 \\
\hline 1969 & 143,50 \\
\hline 1970 & 165,80 \\
\hline 1971 & 178,90 \\
\hline 1972 & 189,10 \\
\hline 1973 & 198,90 \\
\hline 1974 & 205,70 \\
\hline 1975 & 222,30 \\
\hline 1976 & 228,90 \\
\hline 1977 & 249,30 \\
\hline 1978 & 267,10 \\
\hline 1979 & 283,10 \\
\hline 1980 & 286,00 \\
\hline 1981 & 287,10 \\
\hline 1982 & 286,10 \\
\hline 1983 & 289,60 \\
\hline 1984 & 316,40 \\
\hline 1985 & 327,20 \\
\hline 1986 & 338,90 \\
\hline 1987 & 363,80 \\
\hline 1988 & 394,80 \\
\hline 1989 & 426,50 \\
\hline 1990 & 458,20 \\
\hline 1991 & 464,00 \\
\hline 1992 & 503,40 \\
\hline 1993 & 519,00 \\
\hline 1994 & 550,50 \\
\hline 1995 & 565,50 \\
\hline 1996 & 596,50 \\
\hline 1997 & 610,80 \\
\hline 1998 & 626,60 \\
\hline 1999 & 650,20 \\
\hline 2000 & 687,30 \\
\hline 2001 & 684,10 \\
\hline 2002 & 702,60 \\
\hline 2003 & 689,70 \\
\hline 2004 & 763,20 \\
\hline
\end{tabular}

Fonte: Organização Mundial do Turismo (OMT) 


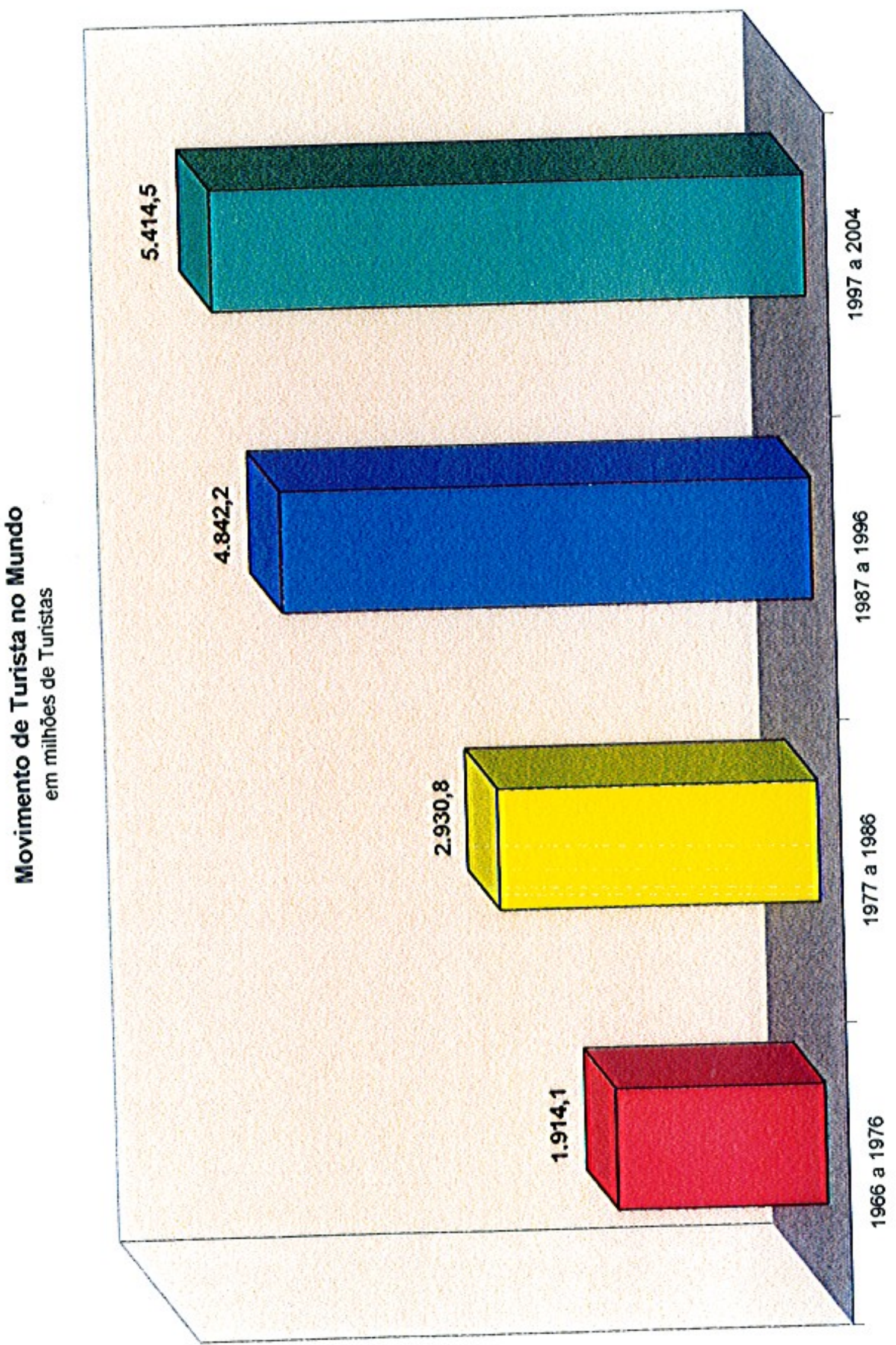


BALANÇO DE PAGAMENTOS

Receita no Brasil com Viagens Internacionais

\begin{tabular}{|c|c|}
\hline ANO & RECEITA (US\$ MILHÕES) \\
\hline 1966 & 12,40 \\
\hline 1967 & 14,70 \\
\hline 1968 & 17,30 \\
\hline 1969 & 28,40 \\
\hline 1970 & 30,10 \\
\hline 1971 & 35,90 \\
\hline 1972 & 38,30 \\
\hline 1973 & 58,50 \\
\hline 1974 & 66,70 \\
\hline 1975 & 71,20 \\
\hline 1976 & 56,20 \\
\hline 1977 & 55,30 \\
\hline 1978 & 68,10 \\
\hline 1979 & 74,60 \\
\hline 1980 & 126,00 \\
\hline 1981 & 242,50 \\
\hline 1982 & 65,4 \\
\hline 1983 & 39,20 \\
\hline 1984 & 65,00 \\
\hline 1985 & 65,70 \\
\hline 1986 & 84,90 \\
\hline 1987 & 101,90 \\
\hline 1988 & 117,00 \\
\hline 1989 & $1.240,10$ \\
\hline 1990 & $1.492,30$ \\
\hline 1991 & $1.079,20$ \\
\hline 1992 & $1.065,60$ \\
\hline 1993 & $1.096,60$ \\
\hline 1994 & $1.050,90$ \\
\hline 1995 & 971,60 \\
\hline 1996 & 839,80 \\
\hline 1997 & $1.069,00$ \\
\hline 1998 & $1.585,70$ \\
\hline 1999 & $1.628,20$ \\
\hline 2000 & $1.809,90$ \\
\hline 2001 & $1.730,60$ \\
\hline 2002 & $1.998,00$ \\
\hline 2003 & $2.478,70$ \\
\hline 2004 & $3.222,10$ \\
\hline 2005 & $3.861,40$ \\
\hline
\end{tabular}

${ }^{\star}$ De janeiro a agosto

Fonte: Banco do Brasil 


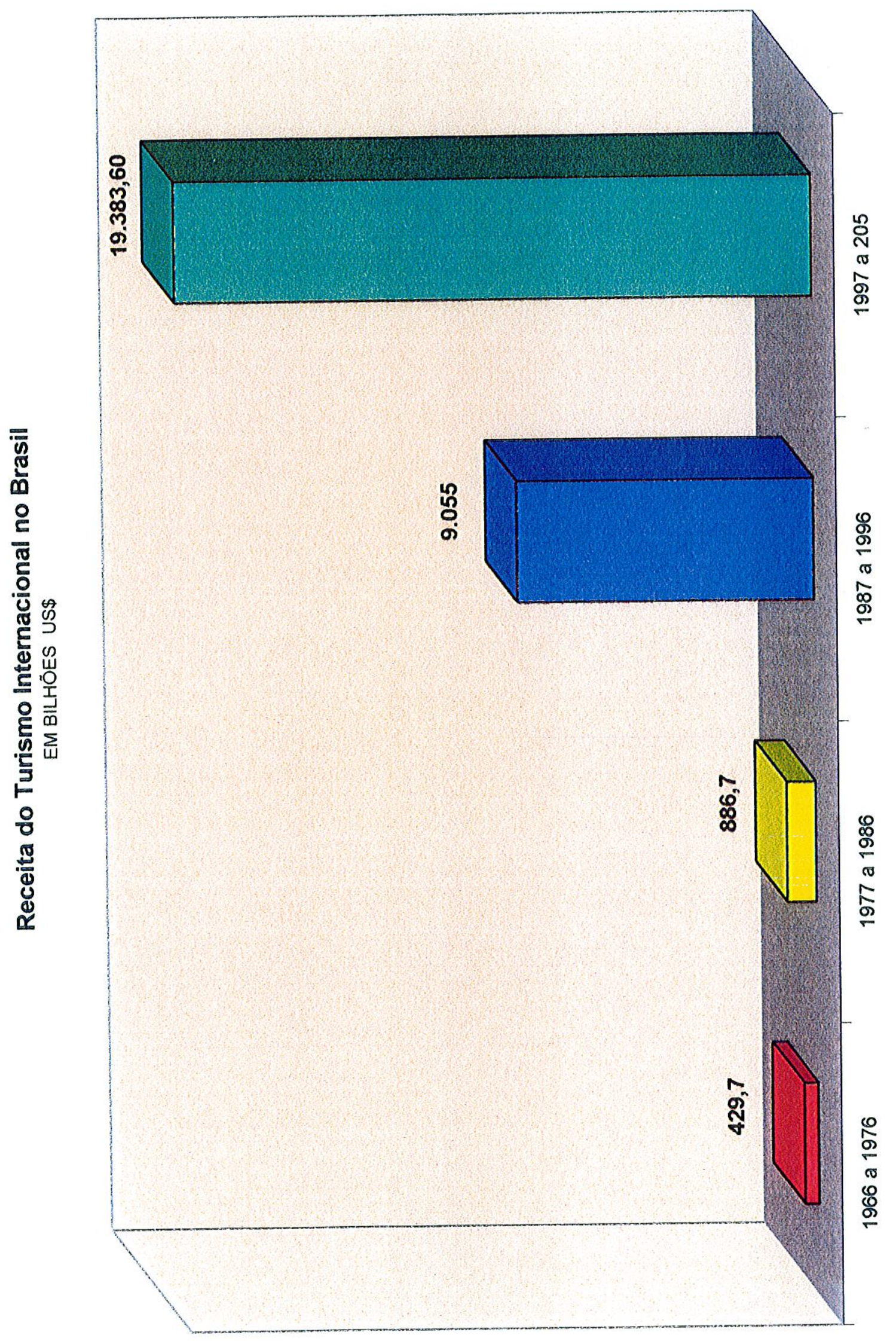


ENTRADA DE TURISTAS NO BRASIL 1966 A 2006

\begin{tabular}{|c|c|}
\hline ANO & $N^{\circ}$ DE TURISTAS \\
\hline 1966 & 133.448 \\
\hline 1967 & 141.421 \\
\hline 1968 & 136.137 \\
\hline 1969 & 162.191 \\
\hline 1970 & 249.900 \\
\hline 1971 & 287.926 \\
\hline 1972 & 342.961 \\
\hline 1973 & 399.127 \\
\hline 1974 & 480.267 \\
\hline 1975 & 517.967 \\
\hline 1976 & 555.967 \\
\hline 1977 & 634.595 \\
\hline 1978 & 784.316 \\
\hline 1979 & 1.081 .799 \\
\hline 1980 & 1.625 .422 \\
\hline 1981 & 1.357 .879 \\
\hline 1982 & 1.146 .681 \\
\hline 1983 & 1.420 .481 \\
\hline 1984 & 1.595 .726 \\
\hline 1985 & 1.735 .982 \\
\hline 1986 & 1.934 .091 \\
\hline 1987 & 1.929 .053 \\
\hline 1988 & 1.742 .939 \\
\hline 1989 & 1.402 .897 \\
\hline 1990 & 1.091 .067 \\
\hline 1991 & 1.228 .178 \\
\hline 1992 & 1.692 .078 \\
\hline 1993 & 1.641 .138 \\
\hline 1994 & 1.853 .301 \\
\hline 1995 & 1.991 .416 \\
\hline 1996 & 2.665 .508 \\
\hline 1997 & 2.8490 .750 \\
\hline 1998 & 4.818 .084 \\
\hline 1999 & 5.107 .169 \\
\hline 2000 & 5.313 .463 \\
\hline 2001 & 4.772 .575 \\
\hline 2002 & 3.783 .400 \\
\hline 2003 & 4.130 .590 \\
\hline 2004 & 4.793 .703 \\
\hline 2005 & 5.358 .170 \\
\hline 2006 & 4.379 .213 \\
\hline
\end{tabular}

*De janeiro a agosto

Fonte: Departamento da Polícia Federal e Embratur 


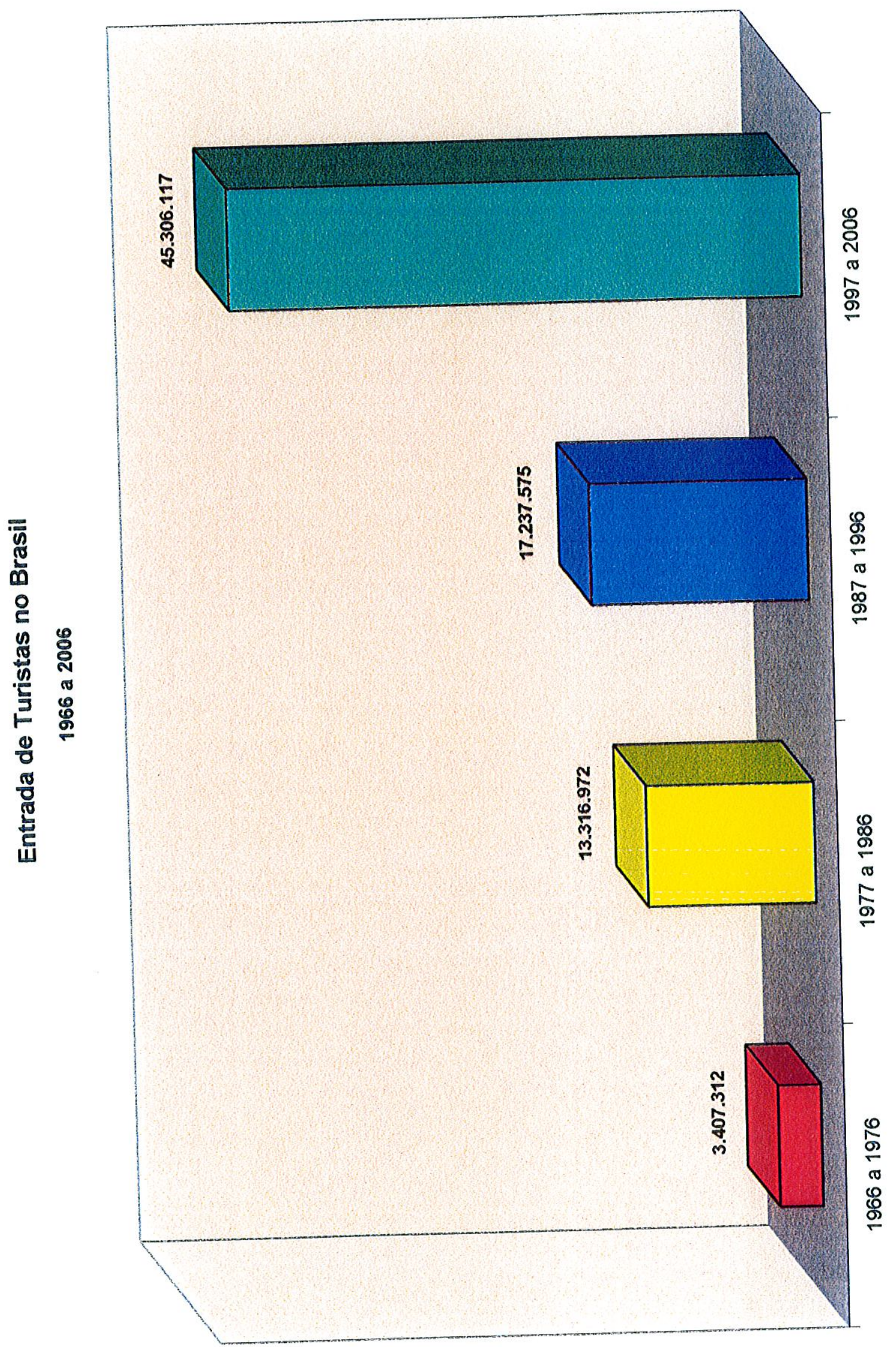

